\title{
健 康管理
}

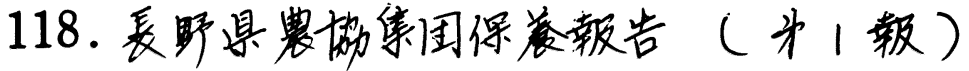

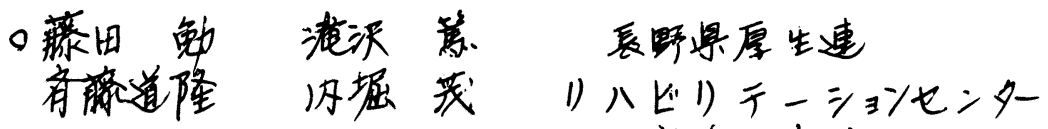
鹿教晹夜院

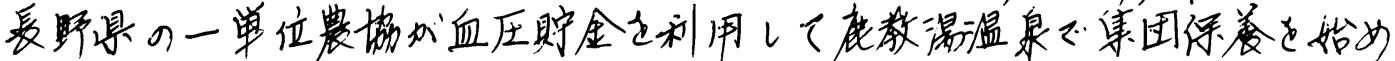

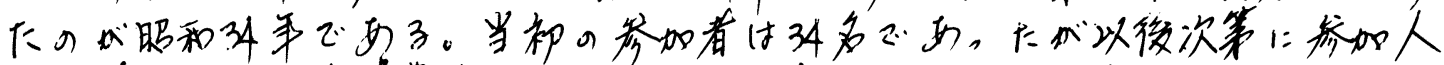

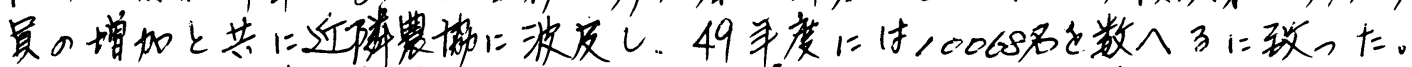

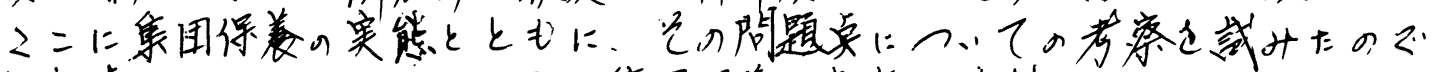

鞎告する。

\begin{tabular}{|c|c|}
\hline & 行 \\
\hline 第 1 日火 & 鹿 教 湯 到 着 \\
\hline " 2 日水 & 血 圧 測 定 \\
\hline " 3 日木 & $\begin{array}{l}\text { 成人病简易ドック実施写真 } \\
\text { 記 息 } \\
\text { 理 学 療 法 教 室 }\end{array}$ \\
\hline " 4 日金 & $\begin{array}{l}\text { 栄 } \text { 養 病 }^{\text {教 }} \text { 室 } \\
\text { 教 }\end{array}$ \\
\hline " 5 日土 & 農 民 体 \\
\hline " 6 日日 & \\
\hline " 7 日月 & $\begin{array}{lll}\text { 血 } & \text { 再 測 定 } \\
\text { 省 } & & \text { 会 } \\
\end{array}$ \\
\hline " 8 日火 & 㷌 \\
\hline
\end{tabular}

1。集团保養の趣旨と体制にへ、て

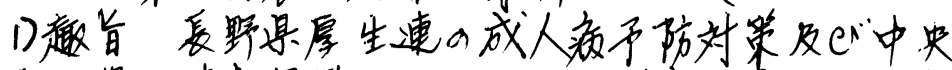

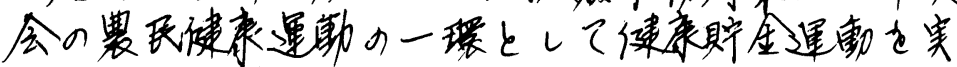

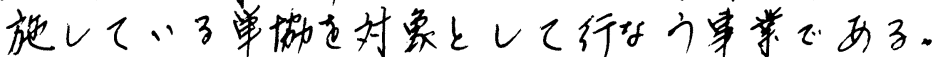

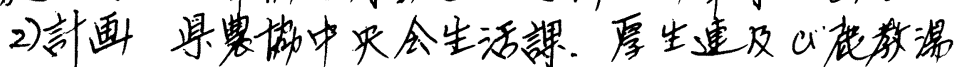

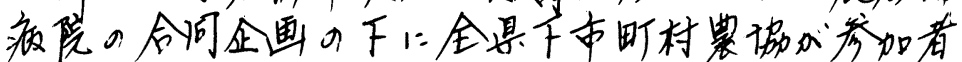

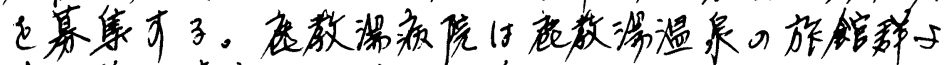

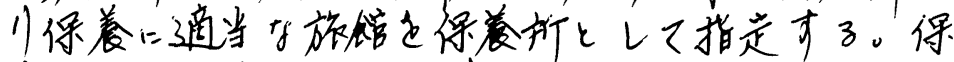

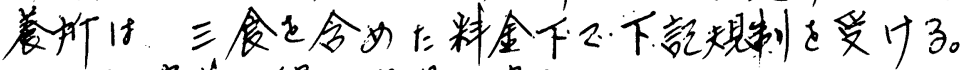

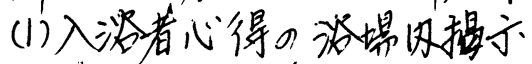

(2)这温泌溥小準偖。

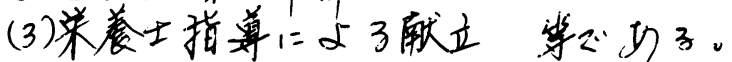

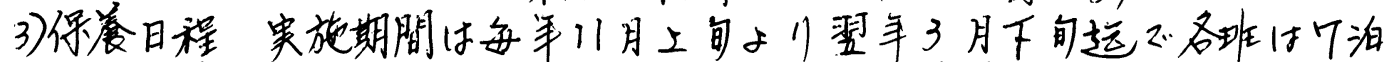

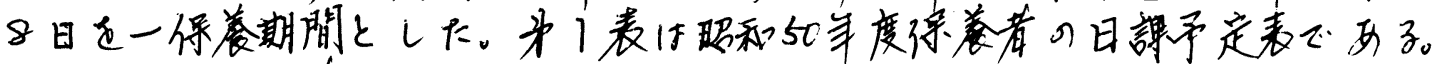
2. 参加者の实態

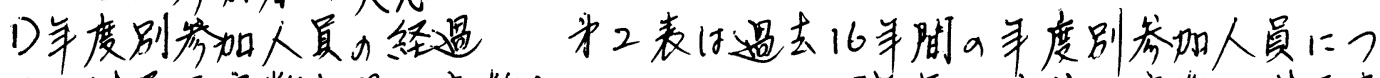

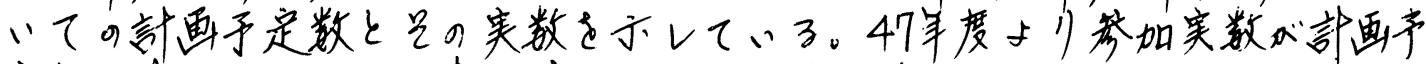

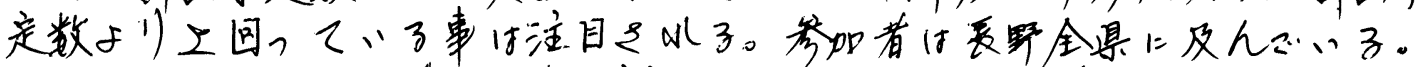

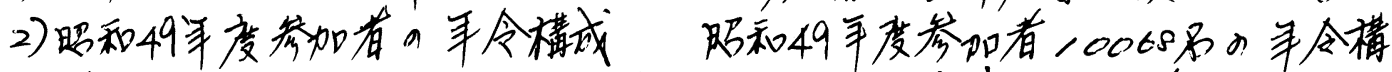

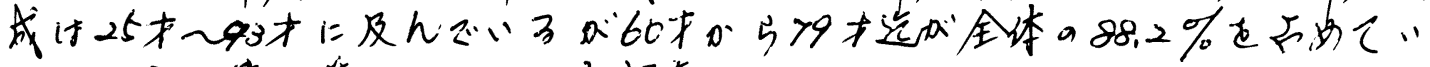

3。3房加者のアン个一ト铜查

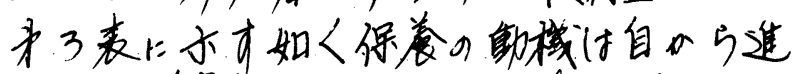

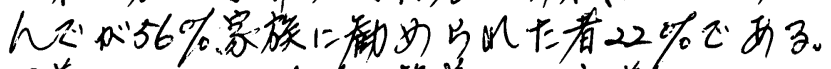

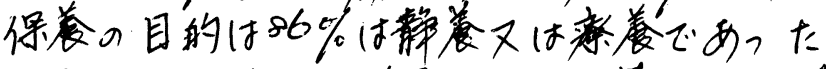

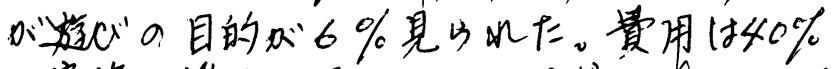

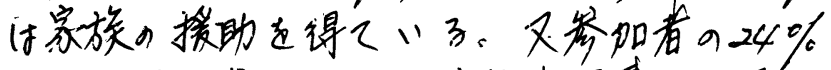
(55回以上参加して执り年中行事としで

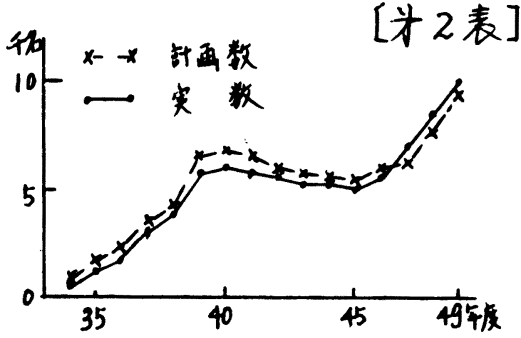

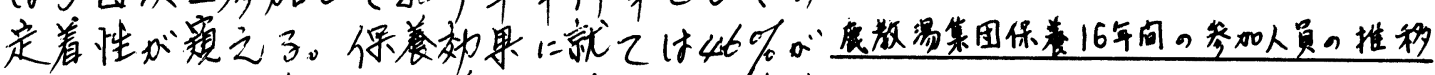

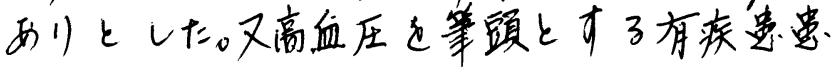


者が收\%見的ている。

\section{集団保落}

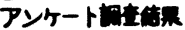

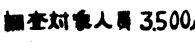

(1)

四奴早 899\%

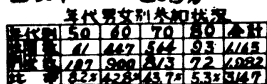

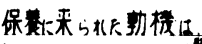
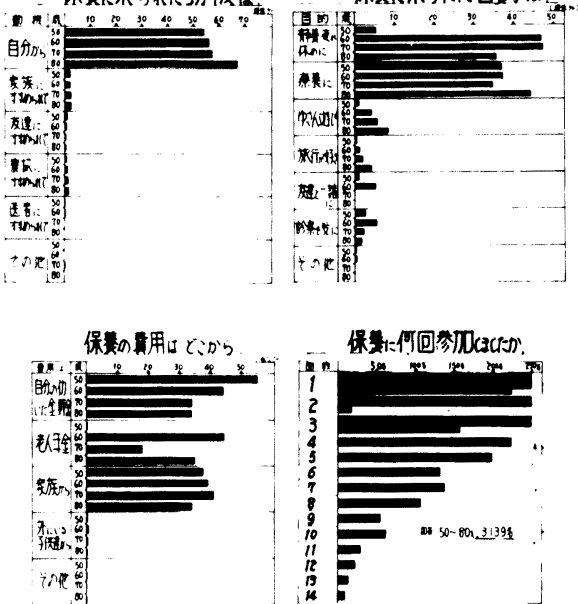

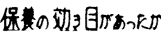

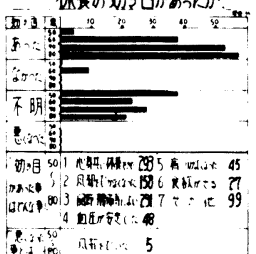

〔事了表了[为4表]

4, 血压测定上高血压者口血压経㝵

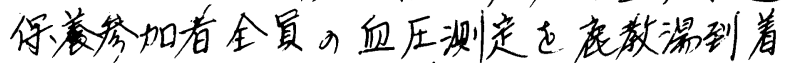

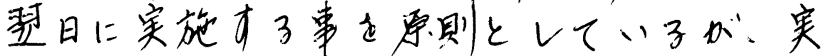

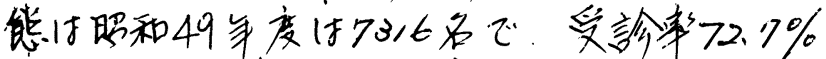

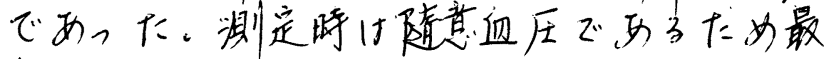
高血后2 00 以上。最低血压110以上㳡病院 医師的外来受部它原则飞した。为表林。

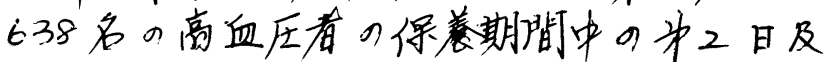

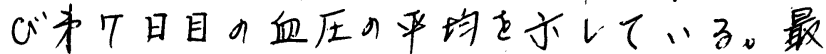

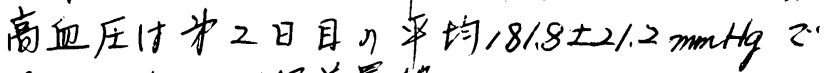

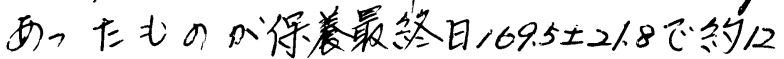

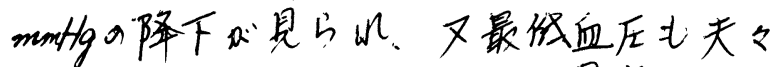

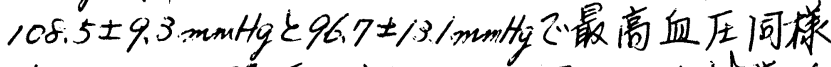

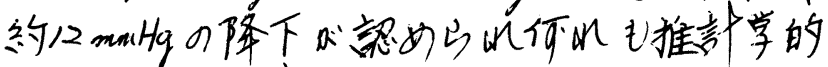

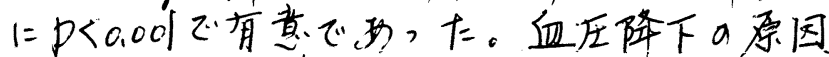
は安静、入 淡初果，外 来受部によ 萝刷投与 及“食事效 果等がすべ 了含毒以下 “当考元

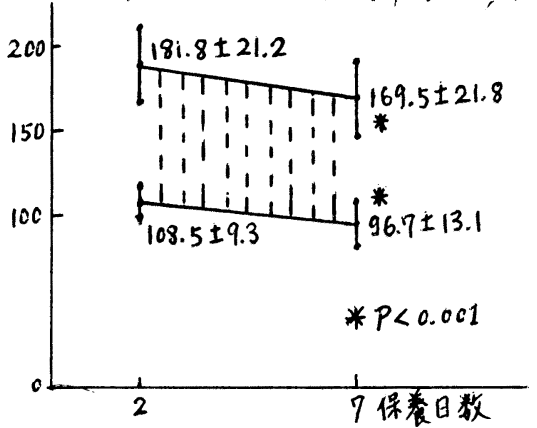
5 几了。

集团保养者中高血压患者 $683 \%$ 。血压经通

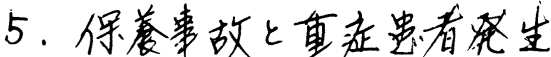
[秉5表了

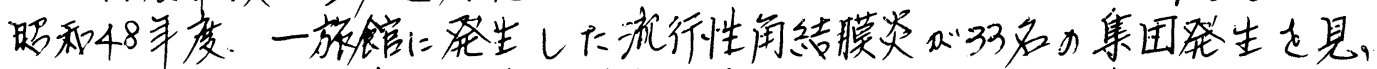
䀡和49年1 った。死亡者は昭和47年度〜49年度何几北名门名で急性心缄死で歹。た。

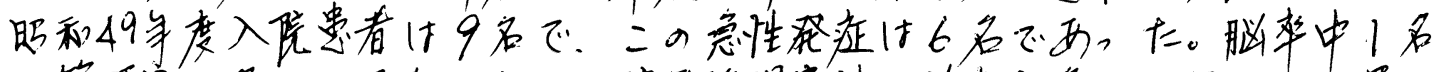

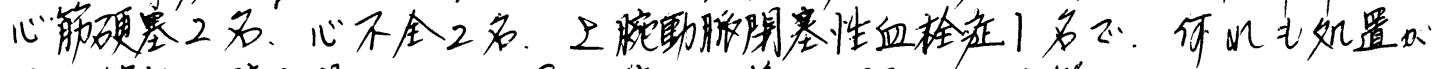

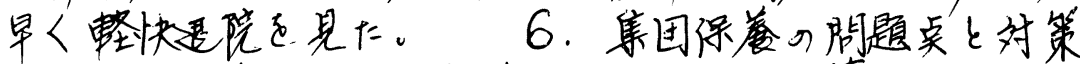

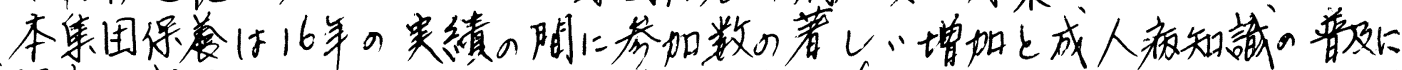

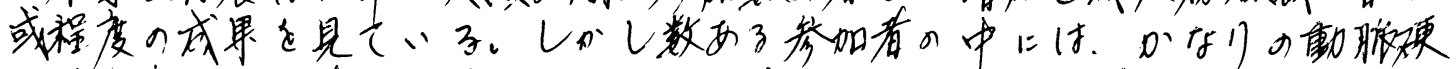

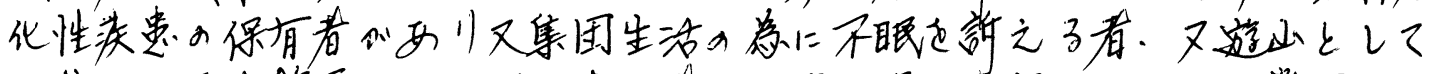

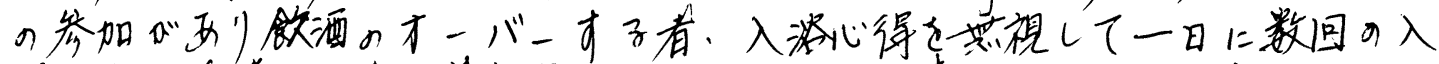

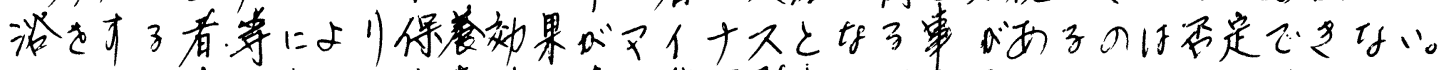

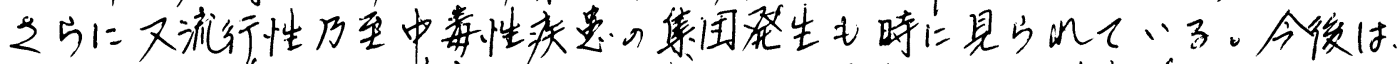

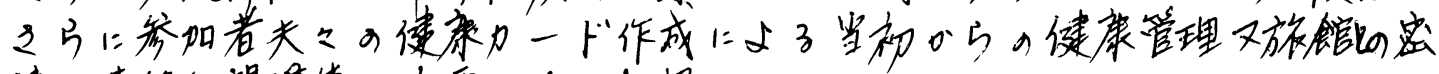
接的速各上提据等心必要で西子と思内心る。 


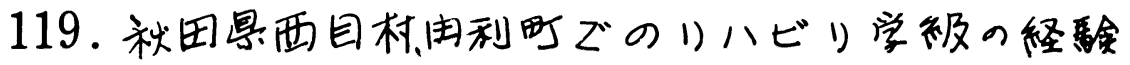

\section{聩田正秀伊落政志}

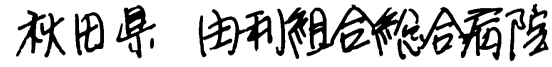

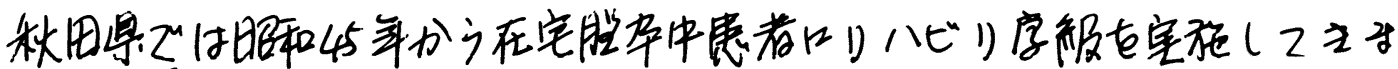

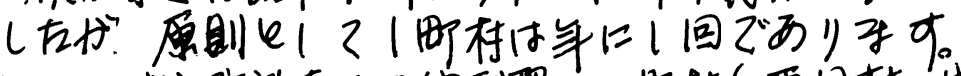

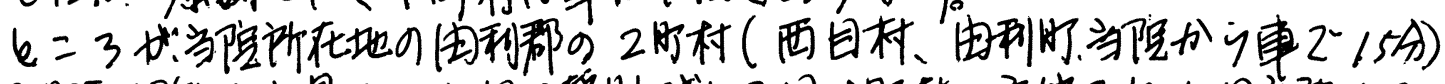

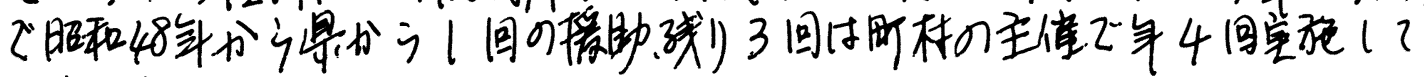
立专左。

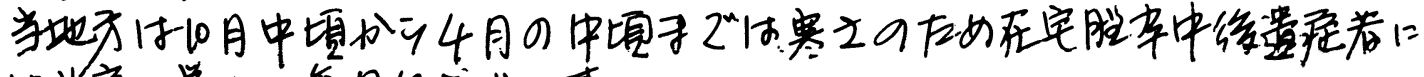

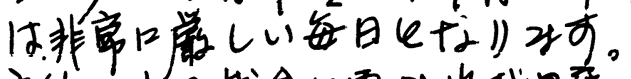

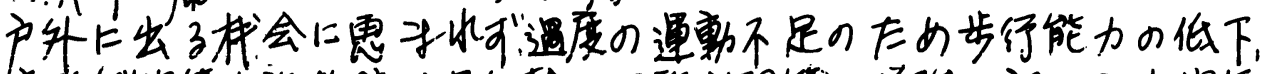

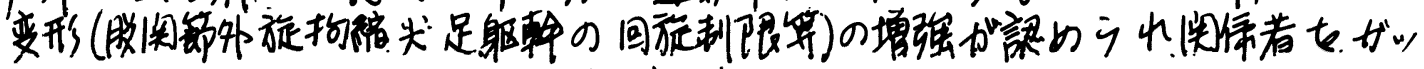

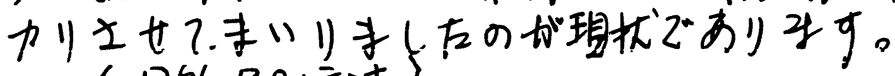

〈目的及心方法了

医房り人ビリテーション治痛を受け退院後の患者の健康官理け担当の，

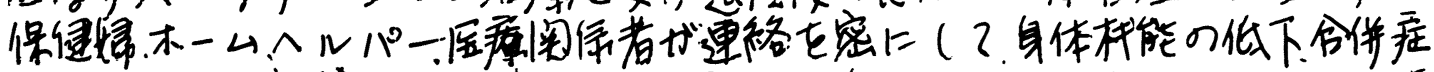

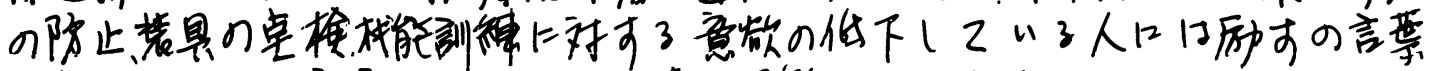

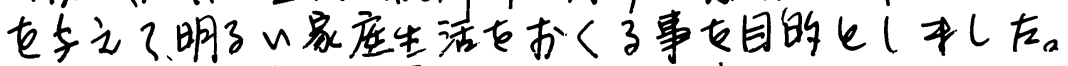

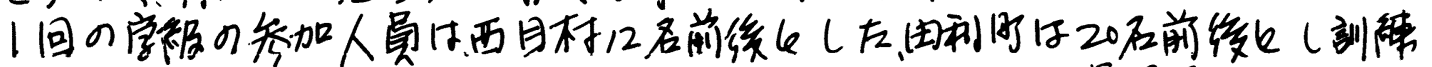

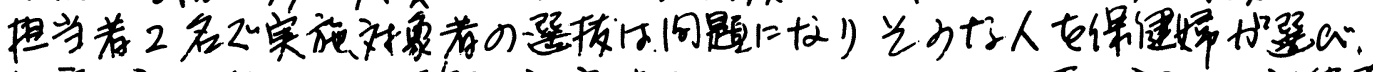

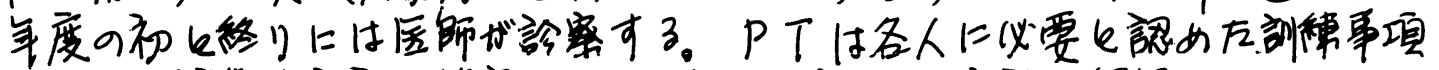

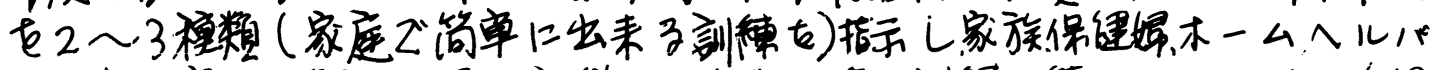

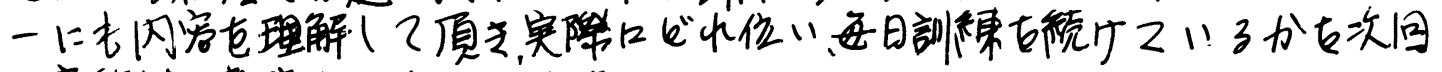
の学被洼上郝吉( ても方い子す。

〔西目村98回房級結果〕

男任21人、平均年令62.3才

金性 7人平均年令 72.27

１回の学衫最高参加人展18人 1回9字缷最低参加人堂9人 平均参加人鼻次

8 回参加6 万人

ク回参加した人

6回参加した人
$2 \wedge$

11

31
5国参加左人 3 人 4回参加LEA 2 人 3回参加左人 / / 2 回参加LE人 7人 l回参加C F⿸厂 9 h

2回，6回参加者上月6人の喜通

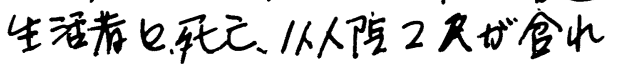
てい打。 


\section{〈話查结果〉}

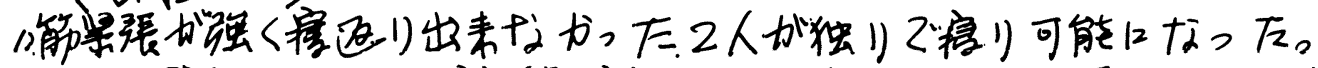

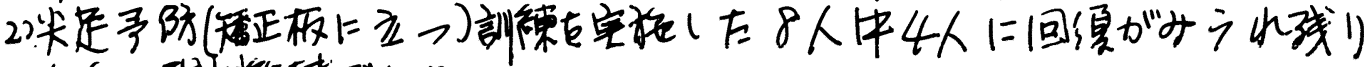

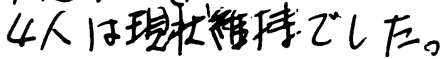

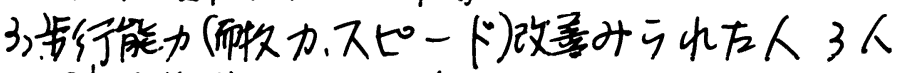

4)理指維持( $2 n 子 人 9 h$

5)当是强生。左人2人

6)入险若

$3 h$

7)死亡

男性 281 平均事令64.37

女性8人平均年令72.67

|回の最高参加人夏 32 人

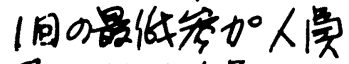

平均积加人目

8 回参加儿左人

7 回参加（左人

6回参加l左人
131

196

$3 k$

31

$5 \alpha$
5回参加(左人 4回紷加左人 了回参加(1大人 2 国参加( 万人 回参加左人
$5 K$

8人

4 人

5 人

31

[おわりに]

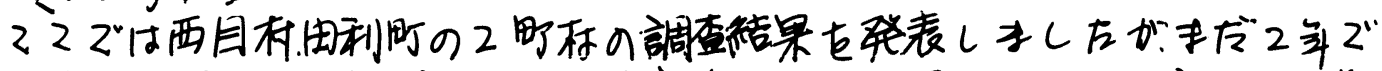

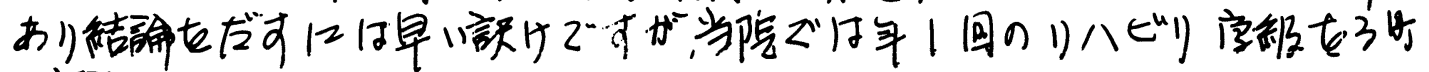
で宣施してい手す。

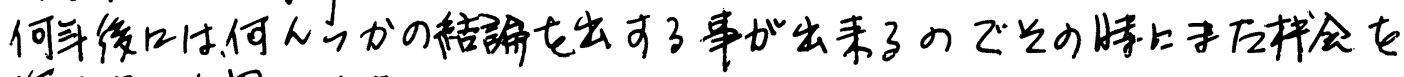
作代い思的柯。

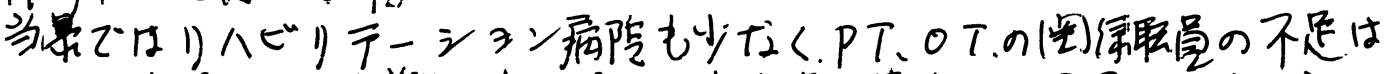

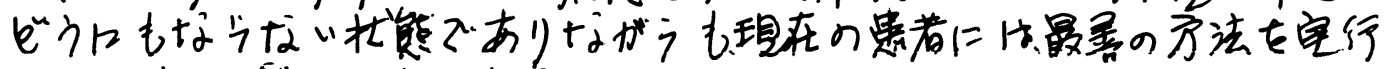

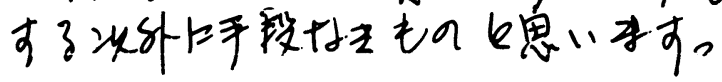




\section{○竹内さだ子}

( 長野県・佐久総合病院、地域看楩活動ブロック委員会)

はじめに

地域医療のセンター的役割をるつ佐久病院では、農村の現実の中て、5・3・ 2の力の配分によつて医療サーピスを行古つている。5の力をホスピタリゼーシ ヨン、つ主り入院患者の治療サービスに、3の力を外来患者のクリニックの仕事 に、そして、あとの2の力在、地域保健活動に向けていろのである。昭和20年 病院開設の当初は、全従業員わずか20名たらずとん5小人数ではすったか、昭 和 21 年、従業員組合が結成され、医療の民主化党目標としての地域医療保健活 動を開始した。当時としてはとくに、無医村の解消、国保の再開をスローガンと し、休日を利用して出張診療を中心とし、“衛生講話”や”移動演劇”在組み合 せて、山間部の部落を巡回した。とのよう字実践の中から「農民のために」とい

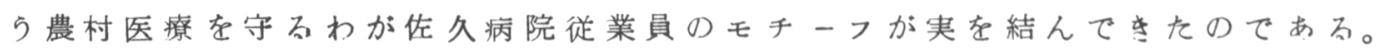

この地域保健活動の方式はその後、昭和 34 年の八千穂村におけ万厂全村健康 管理」、さらに昭和48 年の全県下にわたる「集団健康スクリーニンク」方式の 開始とん5絶えさる発展をとげたのである。又病院内部にも、農村医学講座、農 村医学夏季大学講座、病院衛生展等の開催の努力が続けられ、それらを通してて農 村医学を学ふチャンスに惠本れている。しかし、ともすれば私たち看護部は、独 立してできた病院内の健康管理部にまかせ、とかく院内看護サービスに関係の卉 にこれらの仕事を、おろそかにしがち古傾向にあつたととを、3交替制勤務のし からしむるととろとはいえ。卒直に反省し古けれ壮㐋らないととろであつた。

1, 看護部の地域健康管理活動への参加

昭和48 年1 0 月上り長野全県下の

「地域健康スクリーニンク」方式の実 施の計画がうちたてられた。しかして の因難孛仕事をいか飞遂行す百加。私 たち看護部ではまず 340 名の全スタ ッフを対象に、との計画につんての意 識調査を行なつたのである。その結果 は、図1に示す通りである。 とのよら孝認識と実態の尒かから、活 動の開始となつた。

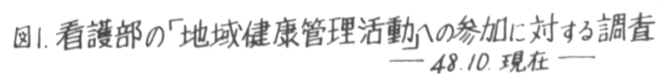

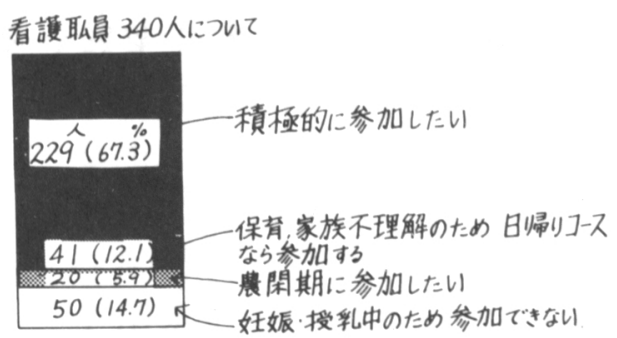


2, 「地域看護活動」プロック委員会

「地域健康スクリーニンク」のメンハーは表1て示すでとくてある。私たちは これを本た「巡回検診隊」とも呼んでいるが、てれに参加する看護スタッフの組 合せ作業のために、看護部独自に、図2の如きブロック委員会をつくつた。てれ は末た、私たち看護部員のての問題に対する認識を深めるために役立つている。

委員会は毎月1回定期的飞開 催し、検診隊参加者からの活動 レボートをはじめ地域住民から の「生の声」などを取り入れ。 ティスカッションを行をつてい 展。

巡回検診はュコース 5 泊 6 日 と古万ため、病棟看護婦の勤㢷 計画在作成す万時点に於て最。 骨の折れる作業となつている。

49 年度の看護部飞於万「地 域健康管理活動」への参加状況 は、表2 に示す如く、年間1人 平均の参加は7.7日である。

おわりに

プロック委員会はさらに新人 及び高看卒業生もとの仕事に参 加させるため、これらのメンバ 一を対象に、健康管理部人の 4 週間寒習をはじ、小海分院 6 力月経験も試みている。

相。変与弤矤療費政策儿苦 しめられつつも、私たち佐久病 院看護部は農村の医撩と保健を 守石技術者チームの一員として 「地域看護活動」に積極的に参 加すへく、先にのへた看護部ブ ロック委員会の組織を中心に、 具体的加厷範子計画老実行す るとともに、との問題につんて の研究を深めていとらと考えて いる次第であ。

表、健康スクリーニング巡回検部隊の楼成

\begin{tabular}{|c|c|c|c|}
\hline & 娥 程 & 人具 & 割 \\
\hline \multirow{5}{*}{$\begin{array}{l}A \\
J \\
1 \\
\text { Z }\end{array}$} & 龨健姆 & $\frac{1}{2}$ & 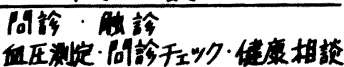 \\
\hline & 着淁璔 & 3 & 採地，值压测定 \\
\hline & 楿理技即 & 4 & 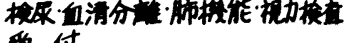 \\
\hline & 这梳金 & $\hat{\imath}$ & 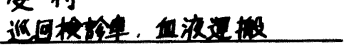 \\
\hline & 計 & 13 & \\
\hline \multirow{3}{*}{$\begin{array}{l}\bar{B} \\
\lambda \\
1 \\
\lambda\end{array}$} & 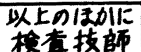 & 1 & 心電龱检直 \\
\hline & 助手 & 2 & "棈县 \\
\hline & 計 & 16 & \\
\hline
\end{tabular}

图2、“地域看設活動」加ック委員会の楼成

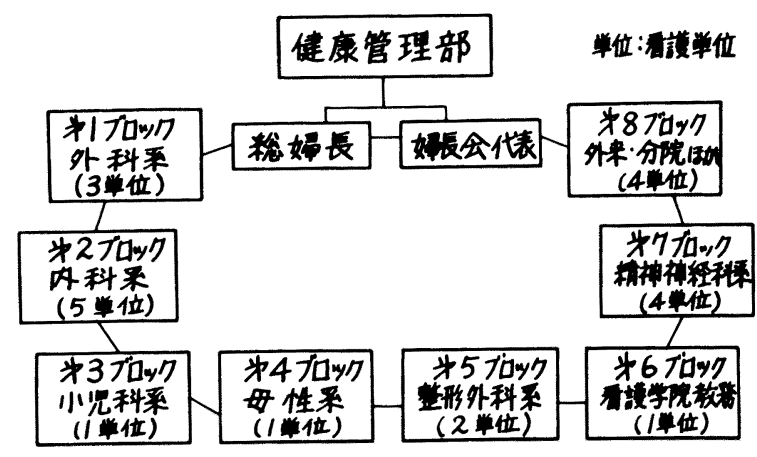

表2.看護部の地域伐䐂管理活㲜への参加状況

\begin{tabular}{|c|c|c|c|c|c|}
\hline \multicolumn{2}{|r|}{ 内 容 } & 日数 & 标等人只 & 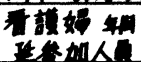 & 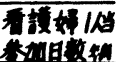 \\
\hline 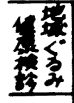 & 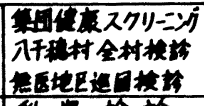 & $\begin{array}{r}206 \\
46 \\
12 \\
\end{array}$ & $\begin{array}{r}36,382 \\
2,329 \\
167 \\
\end{array}$ & $\begin{array}{r}1,448^{x} \\
167 \\
24 \\
\end{array}$ & $4.8 \mathrm{~B}$ \\
\hline $\begin{array}{l}\text { 靕 } \\
\end{array}$ & 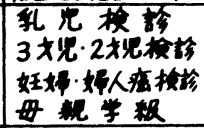 & $\begin{array}{r}90 \\
5 \\
16 \\
48 \\
\end{array}$ & $\begin{array}{r}3.290 \\
200 \\
642 \\
431 \\
\end{array}$ & $\begin{array}{r}271 \\
3 \\
64 \\
32 \\
\end{array}$ & 1.18 \\
\hline 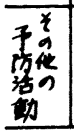 & 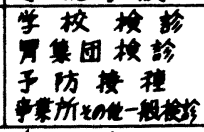 & $\begin{array}{r}37 \\
75 \\
63 \\
121 \\
\end{array}$ & $\begin{array}{l}8.589 \\
3.445 \\
3.591 \\
1.582 \\
\end{array}$ & $\begin{array}{l}39 \\
185 \\
134 \\
252 \\
\end{array}$ & $1.8 \mathrm{~B}$ \\
\hline & bt & 719 & 60.648 & 2,619 & \\
\hline
\end{tabular}


はじめに

看護学生が臨床実習の中で、患者と接する 時その患者をとり本く家族状況、地域的特徵 本を社会環境をどを理解するととは何上りも 大切である。佐久総合病院高等看護学院では 地域と住民生活を学ふために。農村医学講座 農村医学夏季大学講座、地域健康管理( 八千 穂村全村健康管理）への参加、末た病院内健 康管理部実習をどをカリキュラムの中に入れ ている。そのよ5に理論的にも実践的にも、 地域医療を考元石機会に壮恵束れているが、 臨床実習の中ではそれらが必ずしる結びつい ているとは的光的。そとて、一年生の臨床 実習に、とくに地域住民と密着して動いてい 万と思われる佐久病院分院での小海町診療所

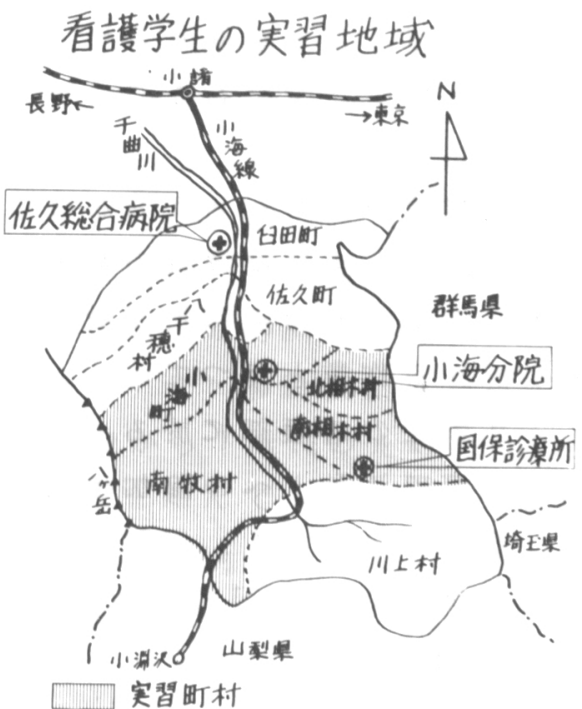
を選び教育を行つてみた。

昭和 48 年1 2 月〜 49 年1 2 月の間に 3 日間つつ、4 回にわたり長期休みを 利用し、希望学生に対して夷習を行つた。実習に入る前段階としては、分院周辺

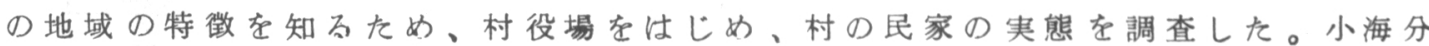
院は従業員1 6 名、ベット数12 床の診療所て、開設以来 20 年の間に、小海町 及びその周辺の無医村地区にとつて欠くととので孛い医療機関と䒚つている。 学生は、実習目標飞基う主、外来、病棟、往診をとの実習から、屯たスタッフゃ 患者と接する中から。大病院の専門分科された看護婦と比へて多岐にわたる知識、 技術はもらろん、”農村を理解して接する心”をもつた看護婦を要求されるとと がわかつた。実習中病院飞来院した患者を疾患別傾向でみると、高血压か最も多

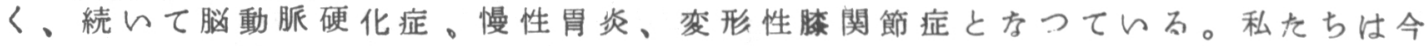
後、とくにてれらの病気につんての知識を深め杖をらをいととを知つた。本た 年令的にみ万と、50才〜 70 才代の高年層が多かつた。1回、2回の実習では小 海分院の理解を深め、3 回、4回では前回までを参考に分院の果している役割を 通して、分院在基点に実際に地域の中に入つていつた。

1 , 村内国保診療所 $K$ 医師 ( 58 才) 訪問一南相木村

との診療所は、現在K 先生とその妻、看護婦の3 人で診療をし、汪とんどが軽 症の患者である。いつ、ととからでも行ける診療所は、住民にとつて心強い存在 
てあるととを知つた。

2。分院を退院した「糖尿病患者」家庭訪問一北相木村

食料品店が少なく、新鮮古肉や魚の手に入りにくい山村て、しか子家族と異古

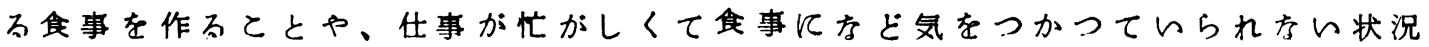
ては。家庭における徹底した食事療法は非常に困難であるととを知つた。教室て 習つた知識を実際に適用する場合のむすかしさをさとつた。

3 , 国保保健婦訪問一南牧村

母子衛生、成人病予防、精神衛生、全戸家庭訪問を中心に行っている保健活動 を知り、中ても村全体を户別飞訪問する全戸家庭訪問は。健康推進委員。生活指 導員、そして保健滑の三者て行い、推進委員は家庭の主婦て、住民のクルーフよ り推䖚され、ュ0軒を一人で受け持ち、健康台帳をもとに医師のいない村での住 民の健康に目をむけ、把握しているといらととを知つた。

4，「权たり老人」家庭訪問一小海町

4 年間リウマチでねたり、夫は入院中で一人暮し、食事や排泄の世話は哖の 人かしてくれ、一週に一度保健婦が訪問、時々ホームへルハーの人が訪れ、清拭 などをしてくれるそのであるが、本人の希望て清拭施行すると污れのひどんとと は警く壮かりであつた。

おわりに

以上の分院での看護実習、及び地域の中での訪問実習によつて。とくに重要と 思われたととは、従来のようを大病院における看護の立場のみならず、第一線に おける医療と保健の仕事の重要性を身にしみて感するてとがでたととてある。 学生は、住民の生活を見。開を、小れ、同時にその人間的をあたたかさをる知る てとかでた。反面。村の中に閉鎖的な奮囲気があるととも感した。

症状かあつても農業におわれ。交通の不便のために病院に行けす。病気が潜在 化する。それか「手革れ」のもとになっている。4回にわたる実習を試みる中で 学生は、チームワークの喜びとともに、環境や地域住民の生活状洗を知るととが でたさらに患者を中心とした農家の家族の実体にっんても、ある程度の理解 を得るととかでを。それが農村医療のあり方や看護サ一ピスのあり方をとの再 認識につながつたととは事実であると思5。学生らは今後、とてて学びえたてと を後輩にる伝えていをたいと言つている。さらに卒業後、農村地域の医療チ一ム の一員としてュニークを活動を展開してくれるてとを信している。

学院でるれらの経験を参考にして、地域実習をカリキュラムの中に許す限り 大担に、大巾に組み入れるととにしたいと思っている。 


\title{
122．農民の健康管理について（第一報）
}

\author{
旭川厚生病院 \\ ○小西行夫杉村箔青木幸範坂本治成沢恒男 \\ 小倉建夫尾崎雅生佐野博昭菅野二郎佐伯周子
}

はじめに; 地域住民の健康を維持し，増進させるためには，健康管理が 必要不可欠のものであるととに異論はないが, 従来の検診は, 対がん協会 飞上る胃検診，結核予防会飞上る胸部検診，市町村独自て実施する成人病 検診（血圧測定，検尿，一般診察程度である）等があり，実施機関が 1 ケ 所でないため検診日のちがらてとは勿論, 検診の結果るバラバラと市町村 保健婦飞報告されて, 住民の疾病予防, 健康管理等保健活動飞非常な苦労 を強いられているのが現状である。検診は毎年実施されているにるかつわ らず，データの蓄積がないため，フォローアップは全くなされていなかっ た。これ等の点を改善し，農村における地域住民（農民）の健康管理を実 施したので報告する。

実施方法;

1. 予め問診票と検便容器を配布し, 検診当日持参させる。

2. 午前 4 時 30 分受付開始，各人に個人フローチ+ートを首から下げさ せる。

3. 午前 5 時より胃バリウム検 査開始

4: 検查修了直後ブドー糖 50 グラム負荷，糖液飲用時間をフローチャトに記入する。

5. 身体計测

6. 胸部 $\mathrm{X}$-線写真撮影

7. 心電図検査

8. 血圧測定

9. 糖液飲用 2 時間後飞採血, 採尿

10. フローチャートを点検し, 全検査修了を確認する。

検査項目; 身長, 体重, 血王測定, 検便（血反，虫卵），検尿（蛋白， 糖），胸部 X-線写真，胃部 X 線写真（6枚），心電図。一般検血（赤血球 数, 白血球数, 血色素量, へ マトクリット值, $\mathrm{MCV}, \mathrm{MCH}, \mathrm{MCHC}$ ), 肝 機能検查 ( 総蛋白, Zn.T.T, GOT, GPT, コリンエステラーセ，アルカリ フォスファターゼ, 総コレステロール), 負荷血糖

所要人員;

1. 対がん協会検診車（胃検診） 4 人

2. 当院 の検診班医師 1 人, 保健婦 1 人, X-線技師 1 人, 衛検技師 2 人, 看護婦 4 人

3. 地元役場上り事務員 3 人, 保健婦 2 人 
一次検診実施以後の手順;

(1) 対がん協会からの胃バリウムの要精検者と胸部 X線写真要精検者は 来院を求めて精検を実施した。

(2) 負荷 2 時間血糖值 $110 \mathrm{mg} / \mathrm{dl}$ 以上の $の$ 多人数のため現地て $\mathrm{G} \mathrm{T} \mathrm{T}$ を実施した。

(3) 精検修了後, データの個人手帳への記入。4 部複写になっていて, 当院健康管理部, 町役場, 地元医師（開業医, 町立病院はない）, 個人に 配 布

(4) 個人手帳人の記入が終ると，午後4 時 30 分上り現地で一般診察の 後, テータによとずを個人指導し, 手帳を交付する。病院保健婦, 町役場 保健婦参加し, 医師の指示に上る保健指導を同時に実施した。

(5) 要治療者は地元医師を主飞連絡

(6) 翌年の検診日むて医師受診の際は必らす個人手帳を持参し，記載し $\tau$ ち5よ5指導

所要人員；(2)飞要した人員は医師 1 人，看護婦 4 人，延 2 日間 (4) 飞要した人員，内科医師 4 人，保健娓 $3 \sim 4$ 人，延 10 日間 実施上の問題点;

(1)胃バリウム検查の処理能力が, 午前 5 時から開始して子午前中に 100 人位てあるため，1,126人の検診に10日を要したてと。をた精検修了 後の個人診察，指導にも10日を要し，その他技師，看護婦。多人数を必要 としたとと。

(2) 負荷血糖採血玉て 2 時間の待時間があり，この間飞他の検査をす〉 められたが, 最後の人は早い時て12時30分位, 多人数の時は午後 2 時頃 でかり, 被検者の空腹と疲労が考えられる。

以上本年より鷹栖町て象施している健康管理の方法を述へたがれを図 示すると下図のよらになる。

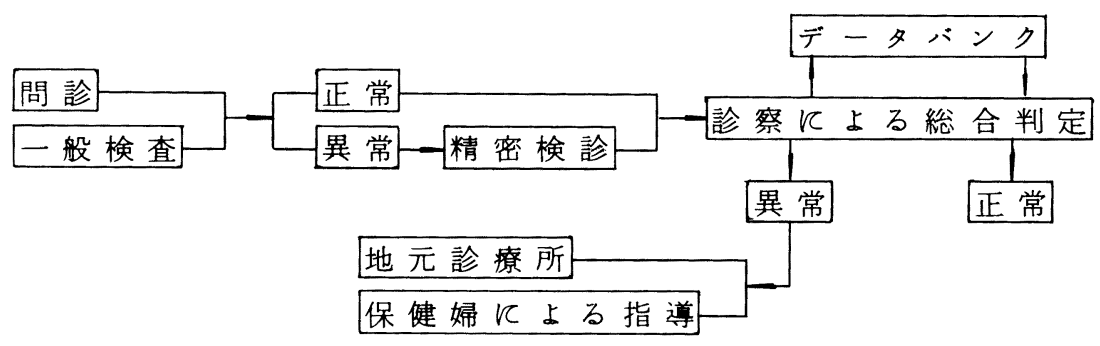




\title{
123．農民の健康管理について（第二報）
}

\author{
旭川厚生病院 \\ ○杉村䈨西行夫青木幸範坂本治成沢恒男 \\ 小倉建夫尾崎雅生佐野博昭菅野二郎佐伯周子
}

鷹栖町町民を対象とした健診方法は，前演題において報告したか，問診 は健診実施日の 2 週間前飞, W A N G 社の組んだ問診表を個人に配布して おいて，あらかじめ記入されたその問診表を，健診日に保健婦が再度点検 するよらにした。乙の問診表は，色々な訴えを別表1のよらな17項目に分 類するととがでるが，男女とす 30 才代，50才代て，訴えの変化を比較す ると，表 2 ・ 3 のどとく，男性ては30才代に比較して，50才代てはアレル キ一系, 循環器系, 呼吸器系, 神経系, 泌尿器系, 眼科系の訴えが多くな り, 女性ては循環器系, リウマチ系, 婦人科系, 整形外科系, 眼科采の訴 えが, 多くなっている。

次飞, W A N G 社飞上り解折された問診表結果及び一次スクリーニンク と精密検査の結果を参考に，医師が受診者全員を対象に面接及び診察を行 い，最終的飞有所見者と認めたるのは，表 4 ・5のでとくてあった。てれ らから貧血は, 男性ては60才代まては年令と共飞增加しているか，女性て は男性に対し貧血の出現度は高く，男性とは逆に30才代，40才代に多い。 又, 高血压症, 虚血性心疾患, 糖尿病, 肥满は, 年令々共飞增加する傾向 飞あった。又, 12 指腸潰痬, 胃ポリープ, 胃潰痬をふくめた胃疾患は表の 上らでるが, その内 1 例, 早期胃癌の例があった。

表 1. 問診の整理項 目

1. アレルギー性

2. 循 環 器 系

3. 呼吸器系

4. 皮交科系

5. 内分泌系

6. 消化管系

7. 血液学系

8. 神経系

9. 機能的又は心理的機能異常
10. 腎系

11. リウマチ系

12. 泌尿器系

13. 産婦人科采

14. 整形外科系

15. 外科系

16. 眼科采

17. 耳鼻咽喉科系 
表2、訴えの項目別及び年令階層別出現頻度(男) 表 3. 訴えの項目別及び年令階層別出現頻度(女)
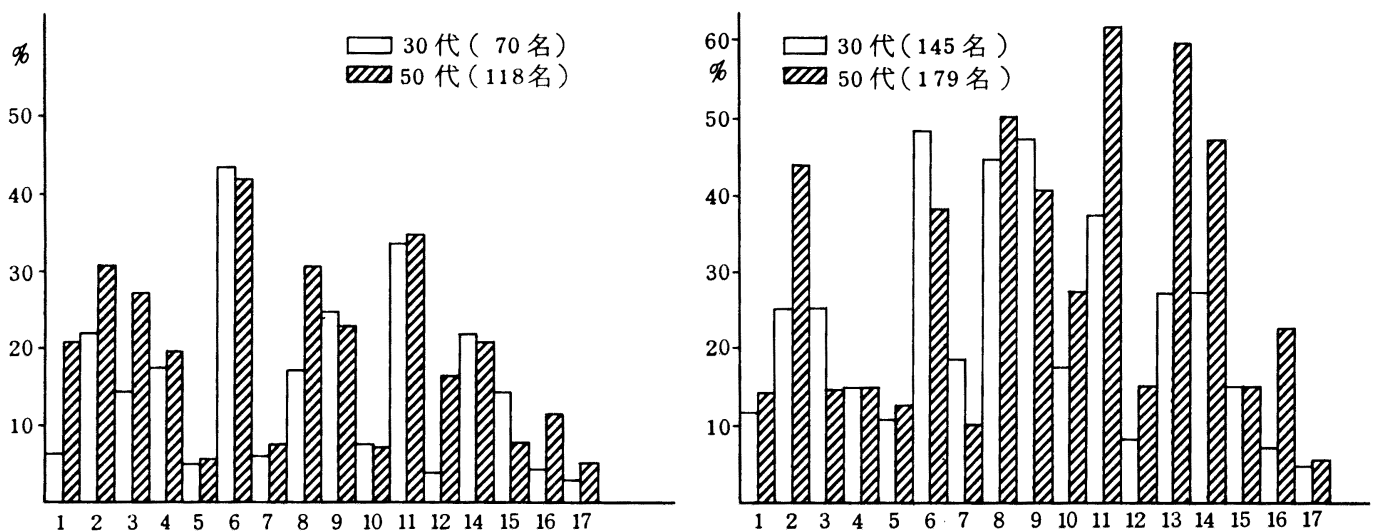

表 4. 年令階層別各種疾病発生頻度

（）：対象人員

\begin{tabular}{|c|c|c|c|c|c|c|c|c|c|c|c|c|c|}
\hline 疾 & 患 & 名 & 性 & $30 \sim$ & 39 & 40 & -49 & $50 \sim$ & 59 & $60 \sim$ & 69 & 70 & $\sim$ \\
\hline \multirow{2}{*}{ 貧 } & & \multirow{2}{*}{ 血 } & $\hat{o}$ & $0(80)$ & $0 \%$ & $6(155)$ & 3. $5 \%$ & $6(123)$ & 4. $8 \%$ & $12(87)$ & 13. $7 \%$ & $1(17)$ & 5. $8 \%$ \\
\hline & & & $q$ & $49(154)$ & 31.8 & $78(200)$ & 39. 0 & $46(190)$ & 24.2 & $27(91)$ & 29. $\hat{~}$ & $5(17)$ & 29. 4 \\
\hline \multirow{2}{*}{ 高 } & \multirow{2}{*}{ 血 } & \multirow{2}{*}{ 压 } & $\hat{\delta}$ & 0 & $0 \%$ & 12 & 7. $7 \%$ & 20 & 16. $2 \%$ & 13 & $14.9 \%$ & 5 & $29.4 \%$ \\
\hline & & & $q$ & 7 & 4. 5 & 10 & 5. 0 & 29 & 15. 2 & 14 & 15. 3 & 6 & 35.3 \\
\hline \multirow{2}{*}{ 心 } & \multirow{2}{*}{ 疾 } & \multirow{2}{*}{ 患 } & $\hat{o}$ & 0 & $0 \%$ & 6 & 3. $8 \%$ & 6 & 4. $8 \%$ & 9 & $10.3 \%$ & 4 & 23. $5 \%$ \\
\hline & & & q & 5 & 3. 2 & 3 & 1. 5 & 10 & 5. 2 & 9 & 9. 9 & 3 & 17. 6 \\
\hline \multirow{2}{*}{ 糖 } & \multirow{2}{*}{ 尿 } & \multirow{2}{*}{ 病 } & $\hat{o}$ & 4 & $5 \%$ & 10 & $6.5 \%$ & 10 & 8. $1 \%$ & 9 & $10.3 \%$ & 3 & 17. $6 \%$ \\
\hline & & & $q$ & 11 & 7. 1 & 18 & 9. 0 & 16 & 8.4 & 15 & 16.4 & 6 & 35. 3 \\
\hline \multirow{2}{*}{ 肥 } & & \multirow{2}{*}{ 满 } & $\hat{o}$ & 6 & 7. $5 \%$ & 17 & $10.9 \%$ & 6 & $4.8 \%$ & 0 & $0.0 \%$ & 1 & $5.8 \%$ \\
\hline & & & $q$ & 19 & 12. 3 & 50 & 25. 0 & 49 & 24. 7 & 19 & 20.8 & 1 & 5. 8 \\
\hline \multirow{2}{*}{ 胃 } & \multirow{2}{*}{ 疾 } & \multirow{2}{*}{ 患 } & $\hat{\delta}$ & 0 & $0 \%$ & \begin{tabular}{|l|}
5 \\
(内1名 \\
\end{tabular} & $\begin{array}{l}\text { 3. } 2 \% \\
\text { 胃瘟) }\end{array}$ & 2 & 1. $6 \%$ & 2 & 2. $3 \%$ & 0 & $0 \%$ \\
\hline & & & 우 & 2 & 1. 3 & 1 & 0.5 & 4 & 2.1 & 1 & 1.1 & 0 & 0 \\
\hline
\end{tabular}

表 5 .
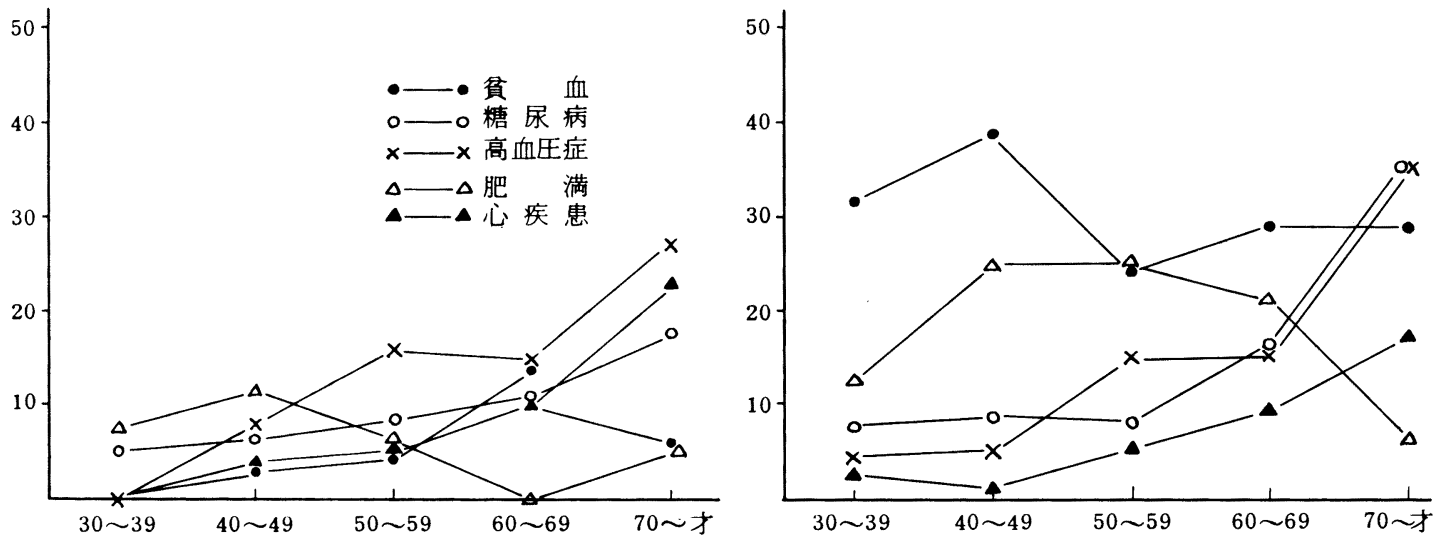
124。朝含町の成人病效策

\section{○林与吉郎林租已哝本郁惠

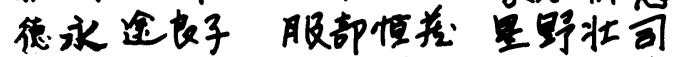

(朝含新㿋所)

私共は通去27年间第人の出をい村ブくり」の理念の下に柾めて地道を步み

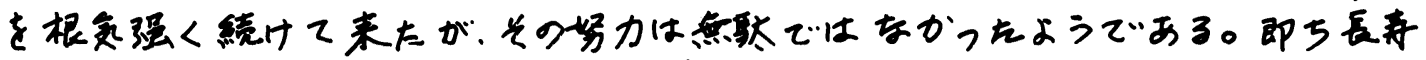

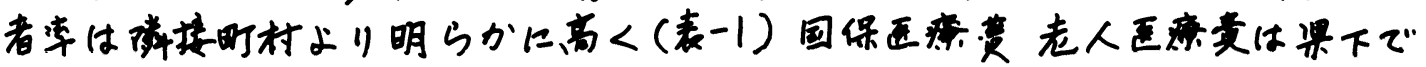

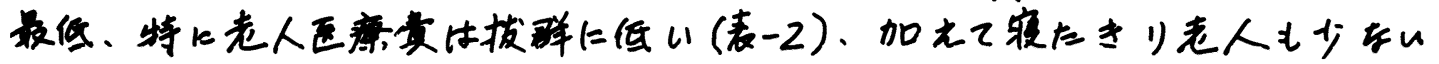
(表一ろ)。この成果を收のた要因として次の3っをあげたい。

(1) PR

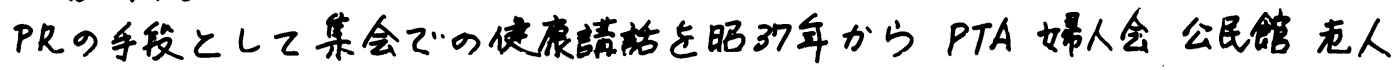
クラブ莮で精力的に行い今日までに約500回。こ水は有力なPR乎段ではある が体力と時闲の消粍が激しい缺卓がある。

侓康謨話にかわるものとして有線放送を利用した健底放送を服39.1月か

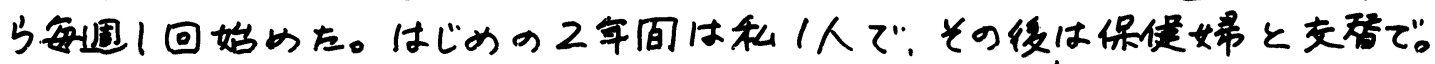

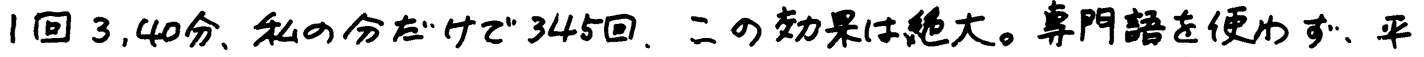

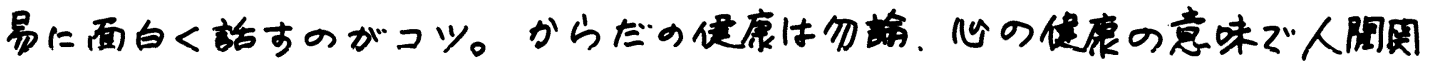

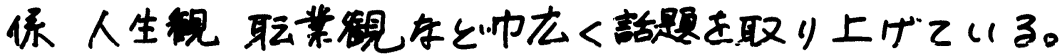

(2) 高血压答理

私共は一般の尚血压は病芠ではなく老化现象とえてとらえている。食物

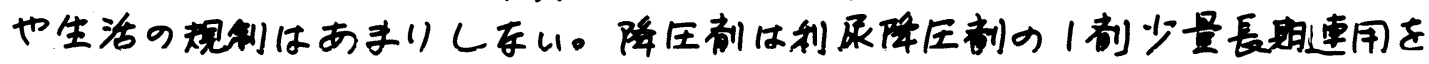

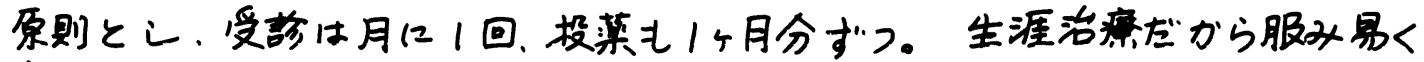

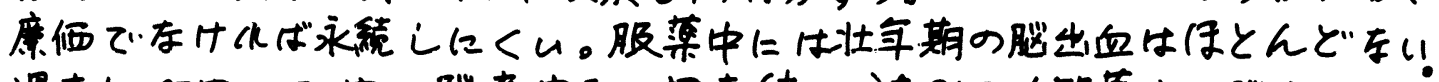

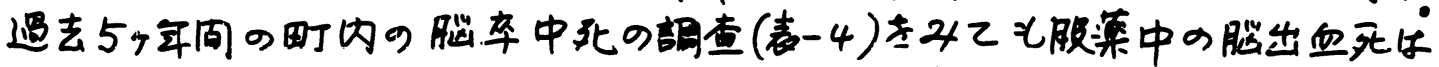
了例で何水も䂵国な高血圧にうフ血性心不全を合併した例であった。腿硬 塞七登病を運らせ延命初果が大きいと思う。高血厓をみつける手段と

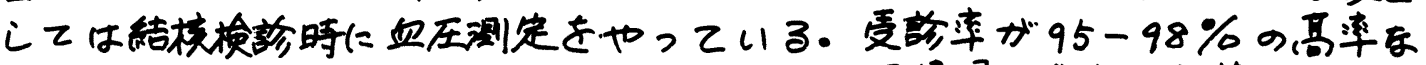

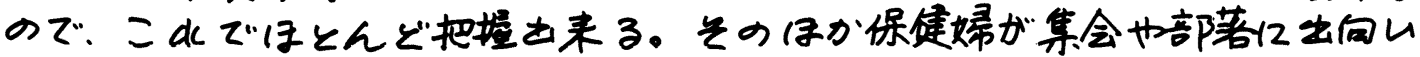

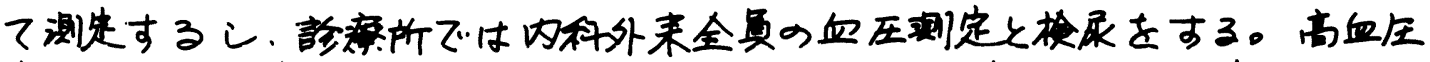

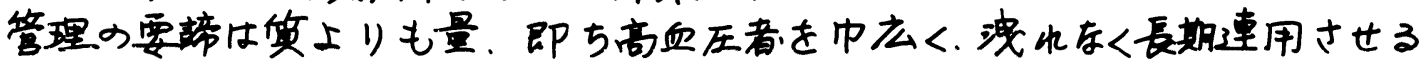
にあると思う。

(3) 老人对策

仍ける閒はハリキッて仂くのが本人も幸世だし、これが赛たきりや老人

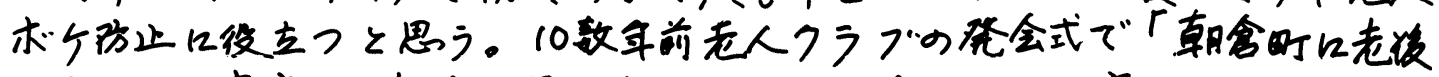
は东山上宣言认、老人大学を壮々年大学々命名しを。当日の老人の㴶手

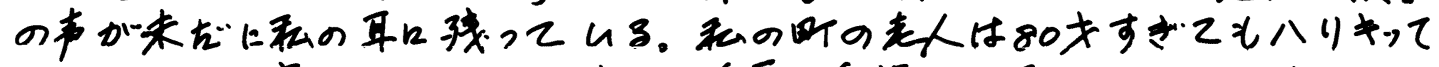

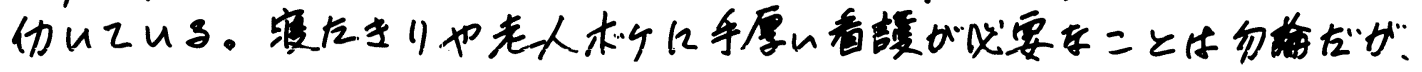


予防は更に重要ではながうか。壮年期には血氛にはやって晨吉し易いか

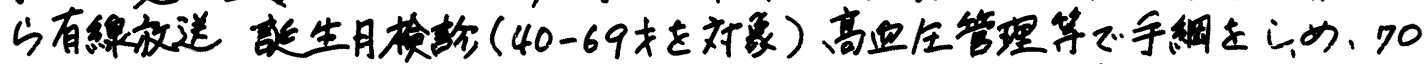

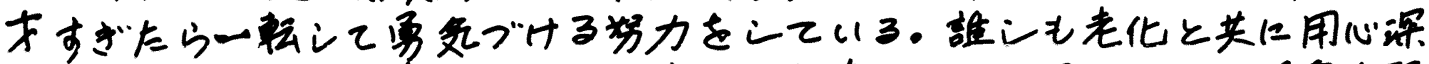

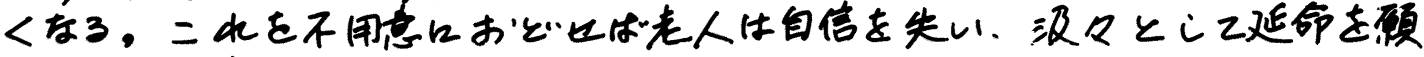

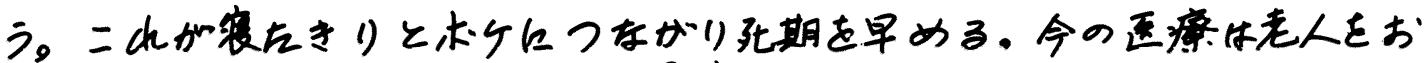

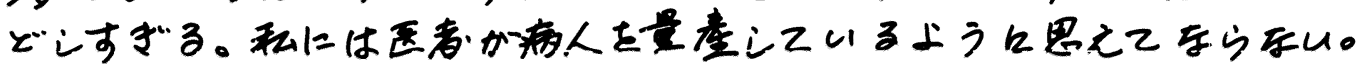

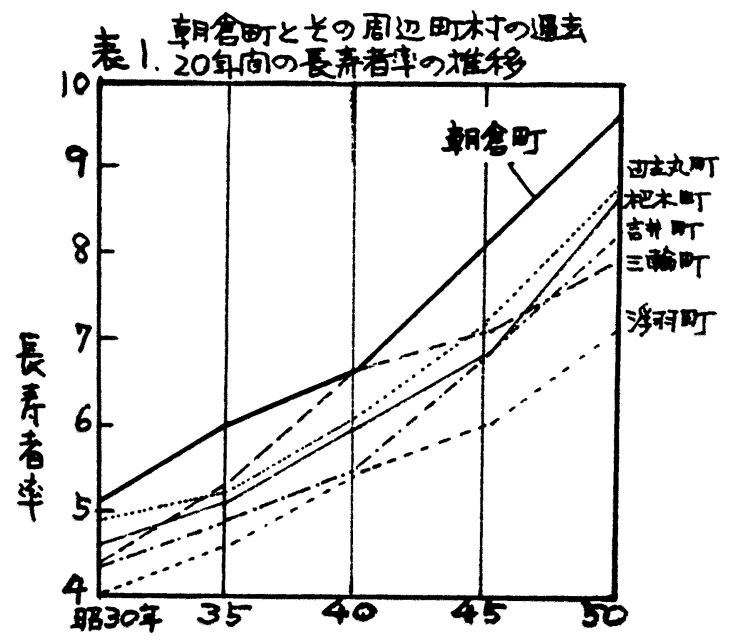

\begin{tabular}{|c|c|c|c|}
\hline \multirow{4}{*}{ 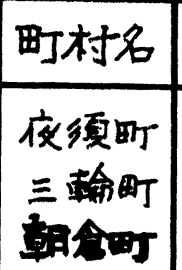 } & \multirow{2}{*}{$\frac{\text { 人口 }}{9.897}$} & \multicolumn{2}{|c|}{ 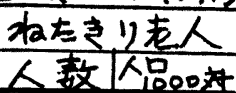 } \\
\hline & & 43 & 4.3 \\
\hline & 9.043 & 23 & 2. \\
\hline & 12.535 & 24 & 1.9 \\
\hline 杷木町| & 11.306 & 34 & 3.0 \\
\hline 宝珠山材 & 2.689 & 20 & 7.4 \\
\hline & 1.655 & & \\
\hline
\end{tabular}

\begin{tabular}{|c|c|c|c|c|}
\hline 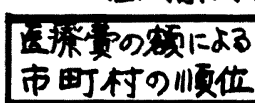 & $\begin{array}{l}\text { 国保 } \\
\text { 件当 }\end{array}$ & 被保敛者|人 & 老件当 & 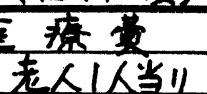 \\
\hline $\begin{array}{lll}\star & 1 & \text { 位 } \\
* & 2 & \text { 位 } \\
\star & 3 & \text { 位 }\end{array}$ & $\begin{array}{l}10.818 \\
10.607 \\
10.228\end{array}$ & $\begin{array}{l}59.194^{17} \\
58.793 \\
58.633\end{array}$ & $\begin{array}{l}25.587^{\prime} \\
23.844 \\
23.840\end{array}$ & $\begin{array}{l}330.420^{17} \\
302.462 \\
276.884\end{array}$ \\
\hline 坞 & 8. 577 & $49 ., 586$ & 16.573 & 229.867 \\
\hline $\begin{array}{l}* 99 \text { 位 } \\
\text { * } 1000 \text { 位 } \\
\text { 位( }\end{array}$ & $\begin{array}{l}7.160 \\
6.710 \\
6.170\end{array}$ & $\begin{array}{l}38.167 \\
35.978 \\
32.769\end{array}$ & $\begin{array}{r}11.732 \\
9.592 \\
8.229\end{array}$ & $\begin{array}{l}130.954 \\
107.601 \\
87.401\end{array}$ \\
\hline
\end{tabular}

表4朝合町の遗去54年間(昭45-49)の脱血管障害死の

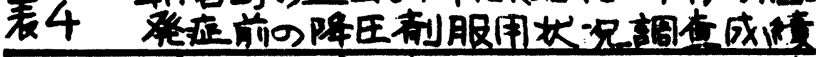

\begin{tabular}{|c|c|c|c|c|c|c|}
\hline & 正常であ? & 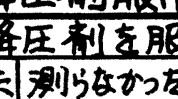 & $\frac{1}{2 h Z^{\prime}}$ & 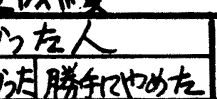 & 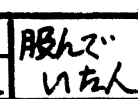 & 計 \\
\hline 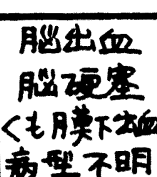 & $\begin{array}{c}1 \\
10 \\
1 \\
0\end{array}$ & $\begin{array}{l}10 \\
19 \\
1 \\
2\end{array}$ & $\begin{array}{l}7 \\
5 \\
3 \\
0\end{array}$ & $\begin{array}{l}0 \\
4 \\
1\end{array}$ & $\begin{array}{l}3 \\
9 \\
2 \\
1\end{array}$ & $\begin{array}{r}21 \\
47 \\
8 \\
3\end{array}$ \\
\hline 計 & 12 & & $\frac{15}{50}$ & 5 & 15 & 79 \\
\hline
\end{tabular}

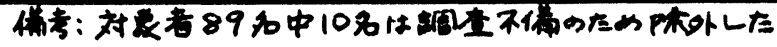




\section{僻地保健の向上に成する研究 (14) 一僻地㟝痛所の役剖一}

○金子勇。八食敬一。田中明。内田昭夫。 (千莱大·医・農医研)

長野県下伊那郡阿南町和合僻地診療所活䡃汃、地区の保健状况の改善に どう役立っているかを検討し、地域保健推進のために、住民生活により近 い場における保健医療活動の充実が不可欠なるを明らかにせんと試みた。

表1·2の如く，和合地区と颣似条件の過踈山村・平谷村を対炤に进んだ。

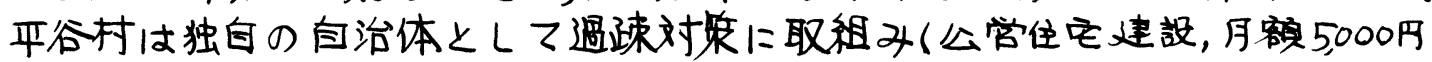
の幼是手当支秴，用軓事学）人口堿少にストップをかけるなど，一定の 成果をあげているが、国保保健施設费は0、給付内容は郡下最低で、保健 所まカ世の保健诏動にとどまり、医療も隣村の南業医の出張を週之日・半日 ブつ受け、国保遖圽をがうじて運営している。一方和合地区は。阿南町 の2分の|の面栍を占めながら，人口は10\%に满たず、棈極的な地区振罢

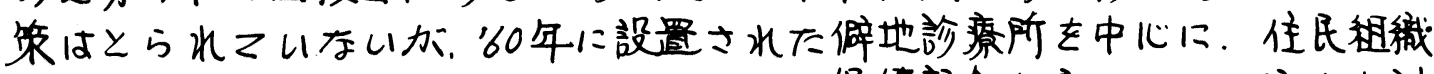

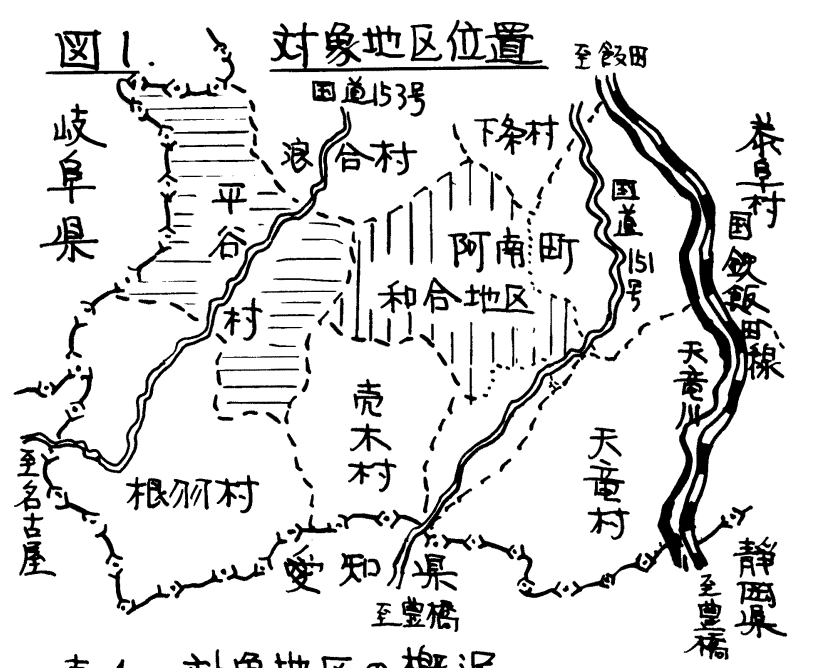

保健部会办育くま水。寄生虫讨

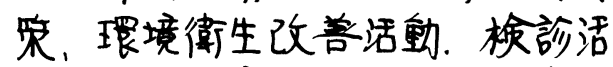

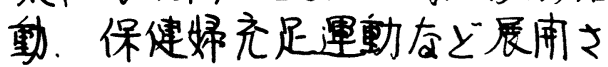
北、人口84弱の町に保健婦吕 3 4人砣保されるに至っている。 医症付週之日.终日診痛上。集落 ガ広沉に散在しているので，新 元病院の场力毛得乙４力所の 月2回の出张診庩所南設して いる。また診愿所は受診者の意 誡的な西压测定を行なうなど、 保健话動极卓ともなっている。

表1。対象地区の概況

\begin{tabular}{|c|c|c|c|c|c|c|}
\hline & & & \multicolumn{3}{|c|}{ 広ぼう ( $\mathrm{km})$} & \multirow{2}{*}{ 農家率( } \\
\hline & 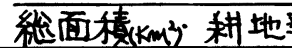 & 林野率(4\%) & 東西 & 南北 & 周两 & \\
\hline 和 合 & 2.6 & 86.1 & 10.9 & 9.9 & 28.0 & 66.7 \\
\hline 平 谷 & 77.47 & 98.4 & 8.2 & 12.0 & 35.1 & 72.8 \\
\hline
\end{tabular}

表2.人口の推移.

\begin{tabular}{|c|c|c|}
\hline & 合 & \\
\hline & $0 \sim 14 \cdot 15 \sim 64 \cdot 65$ 放以上. 計 & L·計 \\
\hline 7 & $\begin{array}{lll}13(32.4) 734(57.7) & 126(9.9) & 1.2 \\
60(21.5) 450(60.4) & 135(18.1) & 7\end{array}$ & $25(62.6$ \\
\hline
\end{tabular}




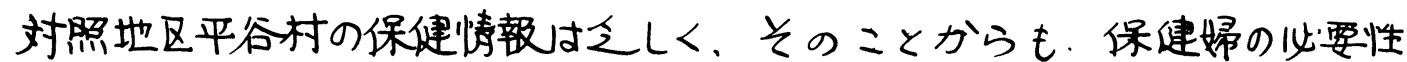
汃痛感之北る。両地区の表る〜6に录した资料に送して比较するに，生话基 船整偖策のとら孔ていない和合に出生率の低下力著しい。また死因掅成で は画地区とも成人病による死亡が多いが，対策が捇秸的に实施さ水て来た 和合の脱血管死亡率の低下ガ注目される。学童の笴生虫卵保有率の推移て は，地域ぐる2対策が实施さ水た和合の低下办影著无ある。受状况にお

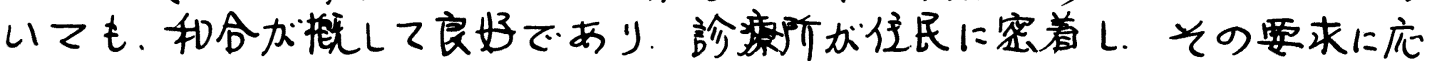
えている卖办何える。和合加平谷より若千の保健指標は良好と考元られる。

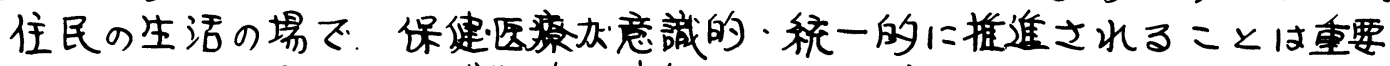

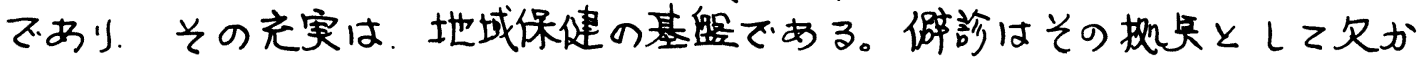
表3.人口㲜態と死因棈成

世ない!

\begin{tabular}{|c|c|c|c|c|c|c|}
\hline \multirow[b]{2}{*}{ 19..年 } & \multicolumn{3}{|c|}{ 和合 } & \multicolumn{3}{|c|}{ 平谷 } \\
\hline & $166 \sim 168$ & $69 \sim 71$ & 172274 & $66-68$ & 69271. & $72-74$ \\
\hline 延人口 & $2 !$ & 52 & 27 & 60 & 2.053 & 2,0 \\
\hline 出生(人口千対 & $27(9.9)$ & $8(7.3)$ & 6) & 9) & $15(7.3)$ & $12(6.0)$ \\
\hline 孚よ昌う & 0 & 1 & 0 & 0 & 0 & 0 \\
\hline 死亡(人口千対) & 2.11 & $28(11.4)$ & $26(11.7)$ & 381 & $25(12.2)$ & $28(14$ \\
\hline 随他管疾兔 & 106 & 8132 & & 11 & 106 & 6 \\
\hline 心疾患 & 61 & $4(163)$ & & 13 & 41 & 81 \\
\hline 筬要性新生物 & 41 & $2(82)$ & & & 51 & $3(150$ \\
\hline 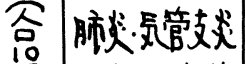 & $6 r$ & $2(82)$ & & $3(113)$ & I (49) & \\
\hline 量|不虑の事故 & $1(37)$ & $1(41)$ & $2(90)$ & $1(38)$ & $4(195)$ & $3(150$ \\
\hline
\end{tabular}
表4. 回虫卵保有者率の推移(小学生)

\begin{tabular}{|c|c|c|c|c|c|c|c|c|c|}
\hline & $19 \cdot \cdots$ & 66 & 67 & 68 & 69 & 70 & 71 & 72 & 73 \\
\hline \multirow{3}{*}{ 和合川 } & 検查者数 & 82 & 85 & 68 & 63 & 53 & 56 & 57 & 57 \\
\hline & 回螂保有者 & 12 & 12 & 6 & 1 & 2 & 1 & 0 & 0 \\
\hline & $($ 率\% & $(14.6)$ & $(14.1)$ & $(8.8)$ & $(1,6)$ & $(3.8)$ & $(1.8)$ & & \\
\hline \multirow{3}{*}{ 平谷川 } & 検㭗入 & 115 & 108 & 96 & 77 & 65 & 62 & 45 & 36 \\
\hline & 回虫卯保有者 & 43 & 29 & 21 & 12 & 5 & 11 & 13 & 7 \\
\hline & (率\% & (37.4) & $(26.8)$ & $(21.9)$ & $(15.6)$ & $(7.7)$ & $(17.7)$ & (28.9) & $(19$ \\
\hline
\end{tabular}

表5. 国保受診状況(1974年・医科・入院外)

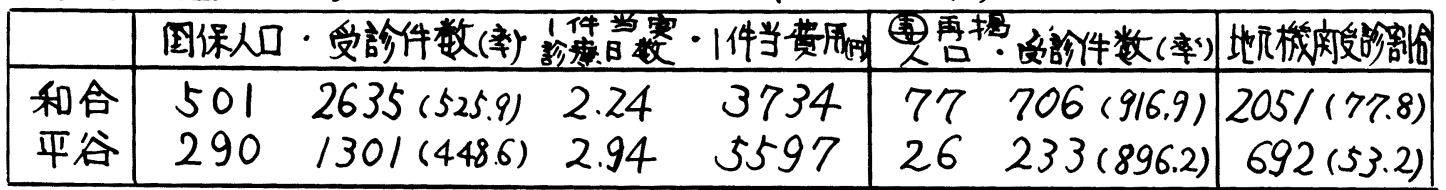

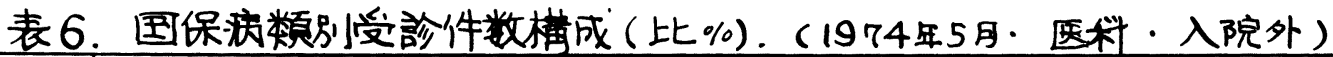

\begin{tabular}{|c|c|c|c|c|c|c|}
\hline & 絍受診件数。 & 詴環器 & 呼吸器 & 消化器 & 的第骨格等 & 种经感觉 \\
\hline 和合 & 20 & 5) & $25(12.0)$ & $25(12.0)$ & $9.1)$ & 15 \\
\hline 平谷 & $173(100)$ & $54(31.2)$ & $39(22.5)$ & $13(7.5)$ & $21(12.1)$ & 1166.4 \\
\hline
\end{tabular}




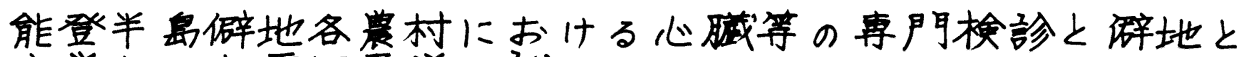
126.大学上の心電囷電送の試み

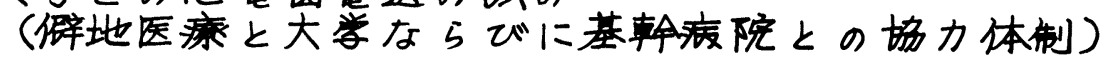

\section{公立能登総合座院長 奥田幸造}

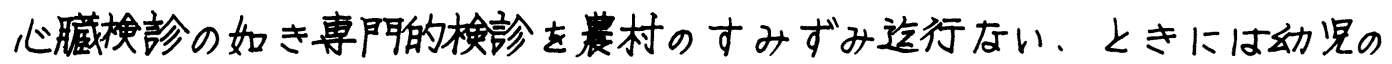
先天性心疾患の発見による心㖑手術例などを経験することもあり、地域の 病院上大学々共同で实施し、成果をあげた实熊を報告する。能登半岛全般

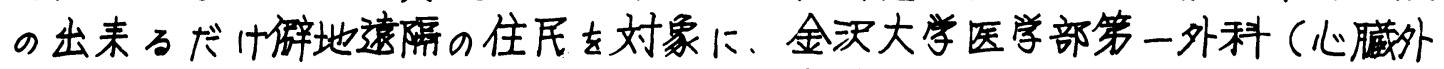
科）の岩教授以下のスタッフに能登䋓合病院のスタッフを加えて、レント ゲン車を始め、病院上同じ設備を出来るだけ整えて、大学病院のサマーキ ヤンペンとして能登の僻地の主として診湶を行なった。演者も金大第一外 科非常勤譜師のー人として、病院のスタッフをたずさえて参加し、図示の 如きデー夕を得た。又本院脑部外科最近の心臟手街6例はいブれも心房或 心室中隔欠摃例であり、二れら碚地の集検より発見されたものであり、 九らの集団検診の意義が大きいことを物痦っている。

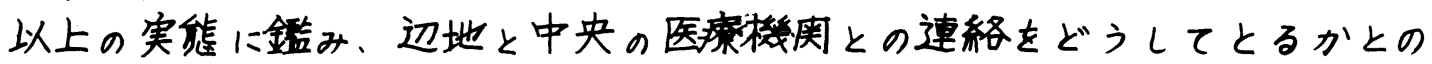
目的のために北陸で初めての電話線利用の心電图電送に成功し、実用化を

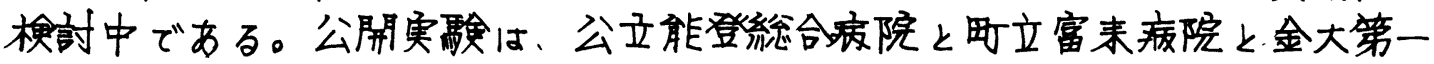
外科結んで行なかれ、边地の患者に大きな福音々なり、乃ちこの電送装 置を使えば、心贜尃門医のいない辺地の医㾌機関でも中央の南門病院に生 のデータを送り、直接専門病院の指示を受け、適切な好置をとることが出 来る。心電图電送は一部大学間、一部都市ではすでに使用しているものの まだ開発の没階であるが、实用的になれば能登地力るどの迅地でも電話線 一本で専門病院上結べば、患者にとって大き飞福音と云える。とくに心筋 梗塞などの緊急な措置に役立っ。

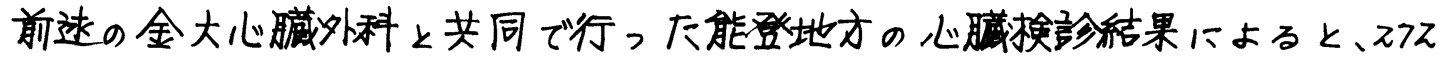

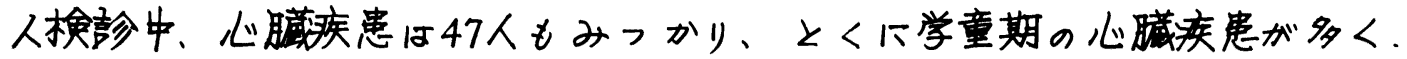

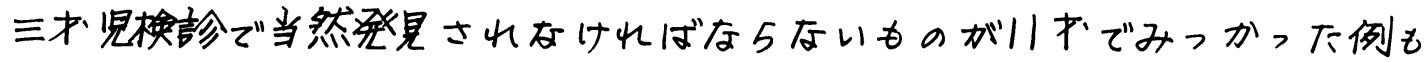
あり、辺地の人た5の心瞒挨診の意義は大きい。

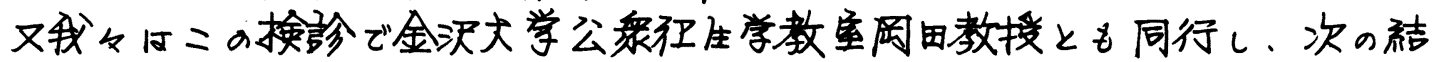
果を知り得た。

石川罙内における各疾患による死亡率をみると、能登の犲咋郡で、石川累

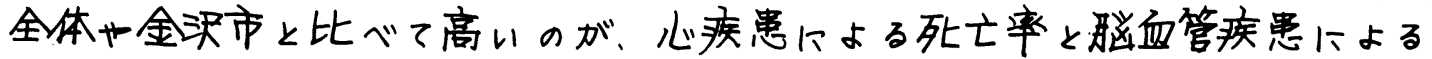
死亡率である。:のことから羽咋郡の疾患の中では特に心疾患々、脑血管

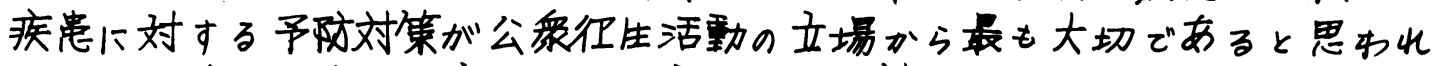
る。又羽咋郡の中でも富未町は心疾费的脳血管疾患による死亡率も、石川 是、金沃市ょり高率で犽昨郡上同心傾向にあるのでンの对策が必要である 
と同時に、糖尿病、脑炎及び交管支炎による死亡率が、羽咋郡全体でも石 川是、金沢市ょり高率であるが、宙来田は产の中でも特に高率であるため これら浐意に対する対策搔自に強める必要がある。

以上四フの疾靑による死亡率が朋倁，特に富来町の代表的なものである

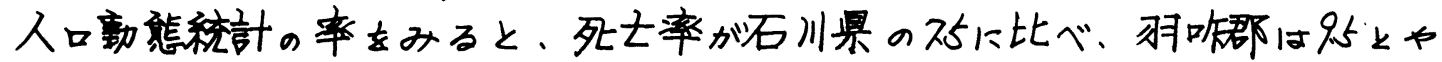
や高率であるの下对し、乳是死亡率が、石川景12.31圷べ6.3と低率である この率の比較等により、羽咋郡では乳晃の保健对策が進んでいると推測士 れる。

心雪四検查

(1)異常数・異常率

（2）年代别異常数・率

\begin{tabular}{|c|c|c|c|}
\hline & 㭘查数 & 景常数 & 晎常率 \\
\hline 計 & 277 & 47 & 13.3 \\
\hline 中 岛 & 35 & 1 & 2.9 \\
\hline 富 来 & 41 & 13 & 31.7 \\
\hline 輪 岛 & 43 & 3 & 7.5 \\
\hline 珠 洲 & 85 & 18 & 9.4 \\
\hline 能登岛 & 73 & 12 & 16.4 \\
\hline
\end{tabular}

\begin{tabular}{|c|c|c|}
\hline & 買常数人 & 率 $\%$ \\
\hline$\sim 9 オ$ & 11 & 23.4 \\
\hline 10 代 & 11 & 23.4 \\
\hline 20 代 & 1 & 2.1 \\
\hline 30 代 & 3 & 6.4 \\
\hline 40 代 & 7 & 14.9 \\
\hline 50 代 & 6 & 12.8 \\
\hline 60 代 & 4 & 8.5 \\
\hline 70 代 & 4 & 8.5 \\
\hline 計 & 47 & 100.0 \\
\hline
\end{tabular}

（3）異常者疾病分類

\begin{tabular}{|c|c|c|c|}
\hline 病 & 数 & 病 & 数 \\
\hline 左空 肥大 & 3 & 左 脚ブロック & 1 \\
\hline 左 空 真荷 & 1 & 心房拍動 & 1 \\
\hline 冠不全疑 & 1 & 渞帽弁用鎮不全 & 2 \\
\hline 㕸肤硬化泟 & 2 & | 度房宝ブロック & 1 \\
\hline 高血圧性心 & 6 & 僧帽弁狭窄症 & 2 \\
\hline WPW症候群 & 1 & 雑 & 3 \\
\hline 整 & 2 & エブスタイン氏症 & 1 \\
\hline 心空中隔欠损症 & 4 & ファロー四徵候 & 1 \\
\hline 自然拥鎖 & 3 & 動朌管用存症 & 2 \\
\hline 心房中隔欠掑症 & 2 & 矤是 & 1 \\
\hline 告天性心疾患 & 1 & 他 & 5 \\
\hline S.S.S & 1 & & \\
\hline & & 計 & 47 \\
\hline
\end{tabular}

心疾患による㱜亡率 (人口10万对 S.46)

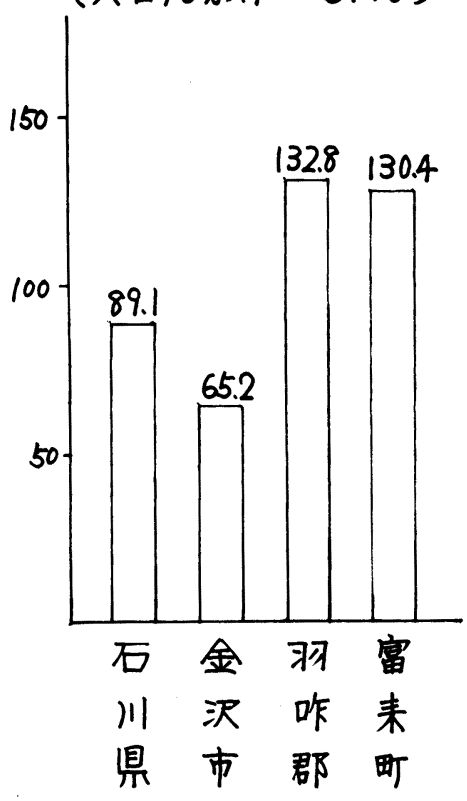


私共は健康診断の結果に基ブいて表りの様に5段階の半定を行すい、

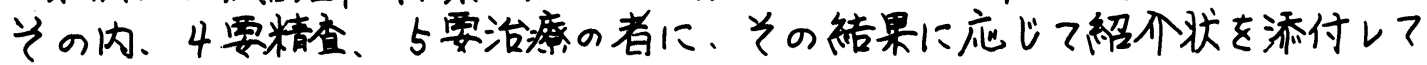

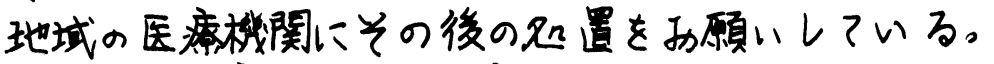

しかし、实然にはどの様に処理きれているのかは明らかでないのが現实 ブある。

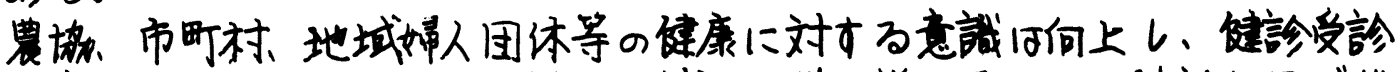

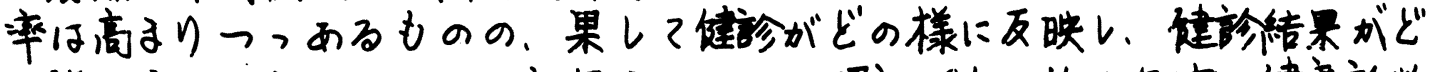

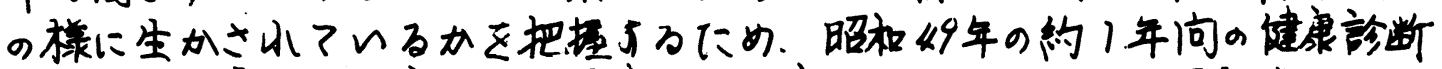

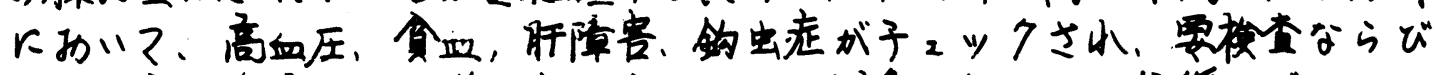

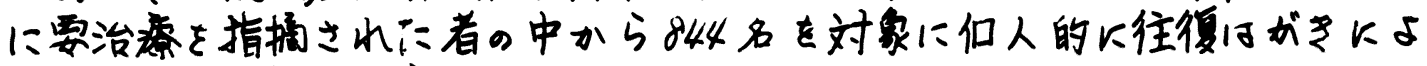
るアンケート铜查を实施した。

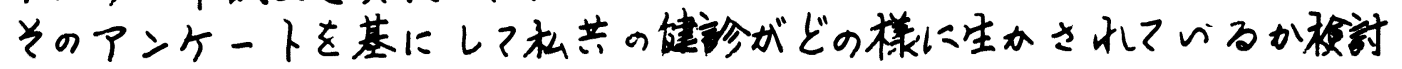
い、以下の通り報告才る。

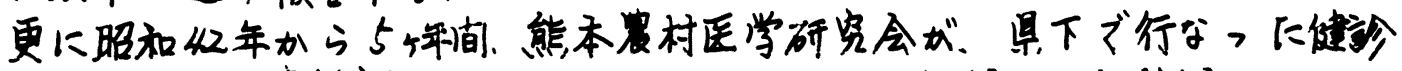

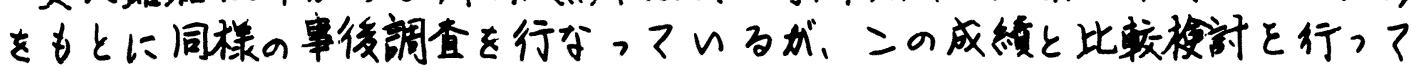
みにい。

表1健康診断総合成絰 一䀡和49年度總合受培数8.854名一

844 名の対象者中回答した

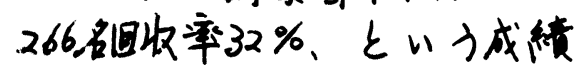
は、昭和《年から姑年に行な

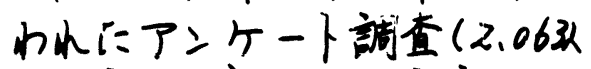
回收率54.898\%比べ回收摔が大 幅に减少しマいる。

前回が䍗场を通しマ行少。 にのに对して、今回は当人に 道接部送して回笿を求めに二

\begin{tabular}{|c|c|c|}
\hline 判定区方 & 久数 & 刺会 \\
\hline I累常かりません。 & 12.914 & \\
\hline 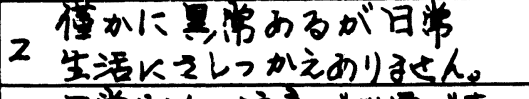 & & \\
\hline 3 日常生活に注志 & $1,1.5302$ & \\
\hline 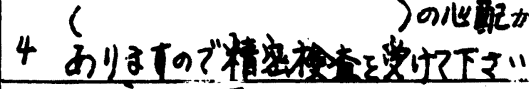 & 18528 & $\underline{z}$ \\
\hline 5 治庶必必要としすす。 & & \\
\hline
\end{tabular}
とに差があると思われる。

誰しもが健康放断を受けがすくなり陡診受診事はアップレても、因エの

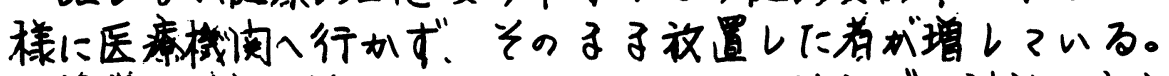

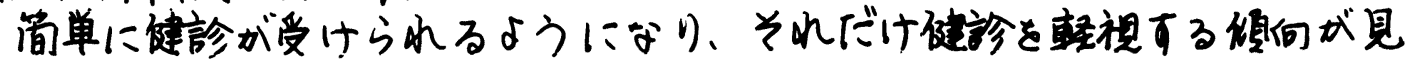
ら水るのブはないだろうか。

又、光㾌不要とされにものが增加しているのに、医饮の判断の相異とい

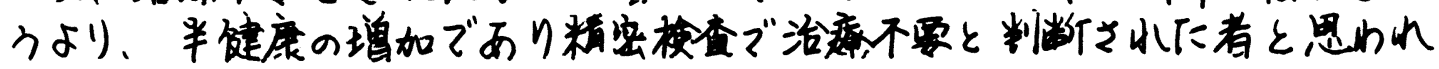


る。

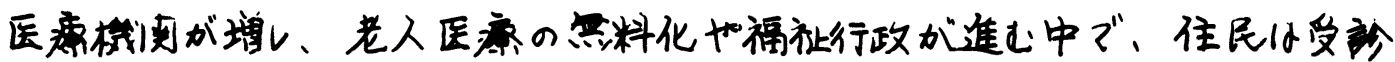

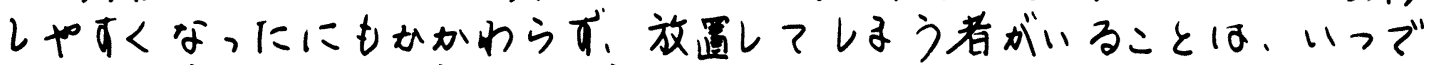

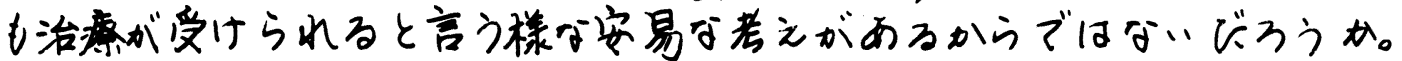

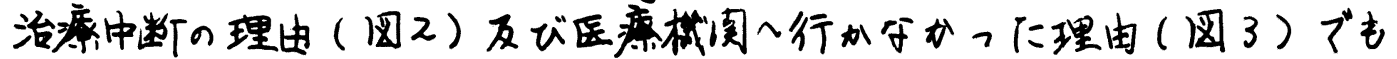

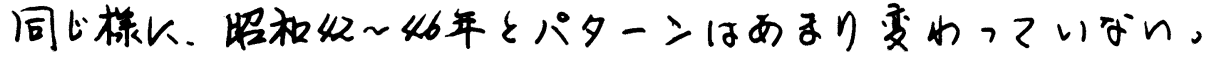

自觉症状がないからという理由が断然多いのは成人病长対する铝哉不足 ブあり球凪なンとである。

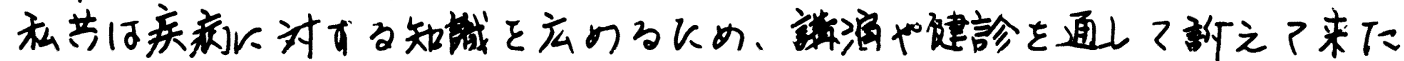

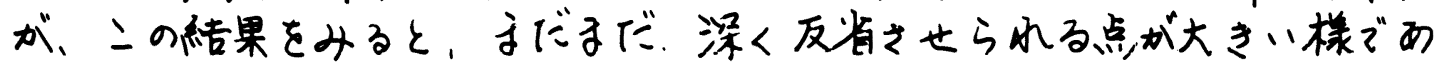
ろ。

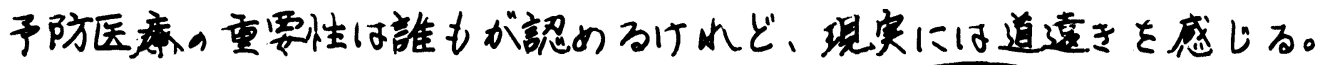

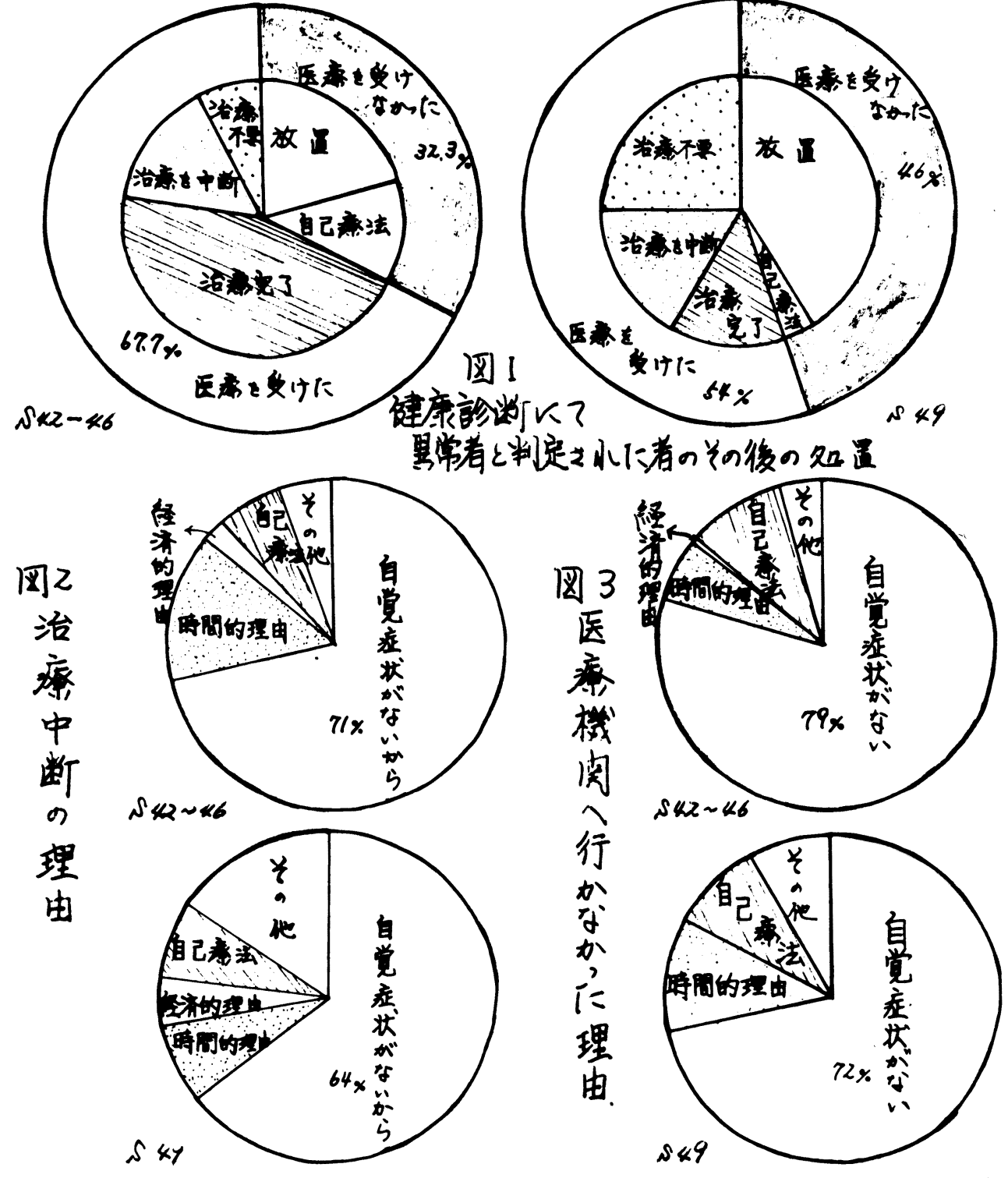


128.

\section{筑後市における健康管理活動}

\section{○城崎栄子(筑後市農荡) \\ 内田栗代(筑後市役所)}

筑後市は人口約40000名、久留米市に憐接した筑後平野の代表的農村地带 である。稻作を中心とした震業がおこなわれ、複合農業としてビニールい ウスによるイチゴ(122晨家年間380tonの生座)、トマト、十スの栽培、い 草の生座 ( 800 户 300 ha)、い草加工（94户，205台）及び果樹として、がどう (300户.1768 tom)。梨（53户）の栽培などがおこなかれる。曹協に所属する 正組合員数は2,884名、準組合皇数は1,049名で4支所に分れている。

演者うは昭和42年以来健康管理活動にとりくみ、特に成人病検診に裏点 をおいて仕事をすすめてきた。昭和45年からは久留米大学医学部の協力を えて健診の精度を高のた。この年はモデル地域を選定し、水田、い草、光 菜、弚の他の地区にわけ、夫々50名をえらんで昭和45年から47年の3ロ年に わたつて，身体計测、体力测定、尿、屎、血液検查、血圧、心電团、肝機 能検查及び医師による診察などの検查を实施して、モデル地域ごとの比較 をおこ尔つたところ、特にい草地带に異血、高血压症が多く保健上問題が あることがわかつた。これはい草の農作賞は機械化されないため、原始的

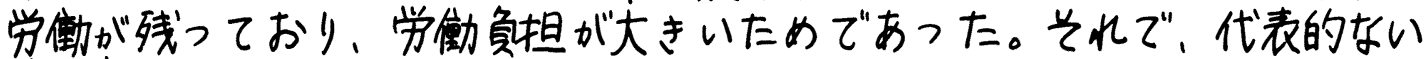
草農家と一般農家との世带主と芝の妻とについて、每月1回、生活時間を

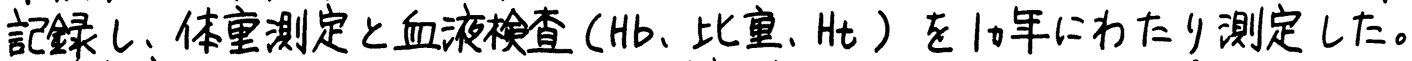

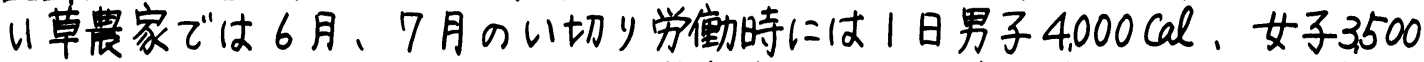

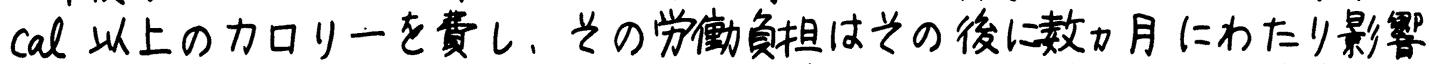
を残していることがわかった。また、い草作業では泥染めという作業があ り、これが乾燥した後、粉塺が䝁生し特にい草乾燥、い草運搬、い草織作 掌時には粉應を吸入する機会があり、い草じん肺症を発生することがわか

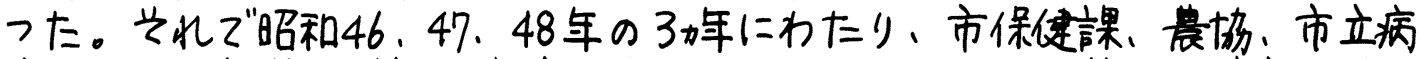
院、久留米大学医学部の環境街生の4者が协力して、い草じん肺症の検診 をおこなった。昭和46年度には200名を检診して有所見者は12\%であった 。一般にい草じん肺症は2度症以下の軽症で，20年以上の長期作業者に邓 放子。対策として、い䋨作業場の防鹿対策、マスクの着用、食生活の改 善を指導した。また、昭和47年からろ年間は日赤、聖マりア病院の協力で 子宫癌梌診灻实施した。

昭和49年には成人病検診を市立総合病院及び開業医の協力を之て実施す るとともに、ビニールハウス栽培徒事者の農菜取报いと贯菜障查の实態を 久留米大学医学部の協力を之て実施した。

対象は晨協に於属し、トマト、十ス、イチゴのいウス栽培従事者175名 
（内、男子90名、女子85名）である。 光の結果

1、11ウス栽培は稻作の裹作として 11 月から垃年の5月垻にかけて おこなわれるが、光のたの年間 の労働日数も男女とも300日以 上のものが多い。ハウスは大型 鉄骨組立で、各世带では5 10

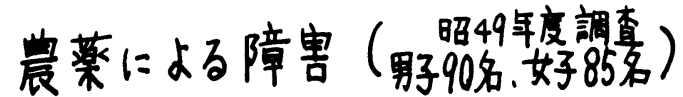
楝を所有している。

2、1ウス内で使用される震寡は一般に低毒性のものが多いが月に4〜5 回散布がおこをわれ、光れぞれの世带で動力散布器を使用し、世带主 がホースの筒先をもち、主婦はホースたぐり、ホース持ちになるのが 谱通で農菜の影響をうけるのは男子が多い。

3.震薬の年間使用回数は男女とも20〜29回のものが多く、なかには100 回以上のものもいる。

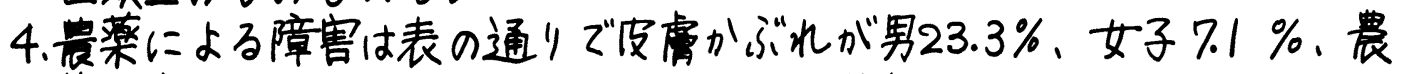
菜中毒は男子 $20.0 \%$ 、女子 $10.6 \%$ にられた。

5.1 年間の散布俊に頭痛、めまい、呕吐、眼の充血、皮䖉か心゙北などの 農菜散布との係のある所見を訴えたものは男子で33.3\%、女子では $28.2 \%$ とか方高率で

6、健康調查所見として血清GＯT，GPTの異常所見、尿中蛋白、糖の陽 性所見は男子の方が瓷生率は高かった。

7.貫菜散布によって特に健康障害が進んでいるという成績はえられなか つたが、慢性的影響については今後とも注意していかねばならない。 菠後市は医療機肉にも恵まれており，近年改策された市立総合病院を有 し、地域医師会とも連係老密にして、また久留米大学医学部の指尊と協力 をえて、地域の健康管理活動も着实に進めることができている。

これら一連の健康管理活動を通じて明らかになった点は、地域住民が

1、健康に関する意識の向上がみられること。

2、光のため受診率が著しく高まったこと。

3、有所見者で市立病院也地区の開業医で早期受診するようになつたこ と。

\section{筑後地方惯行農作業}

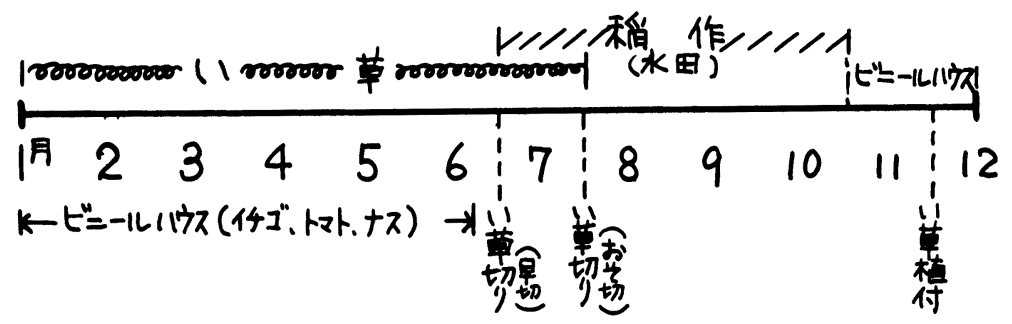




\section{9。爱媛果一患山村における健康管理活怔の10力年のあゆみ}

\section{○圈田尚不。永是宏行。八杉伸輔

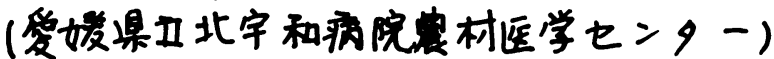

（はじのに）下大野地区は、爱媛県広見町の東北部に位置し、標高200 〜 $600 \mathrm{mg}$ 谷間にVらけた户数/ 84 户。人口73/名9貫山材である。 農業の経学規模が55 、と零細なだ、震業のみでは生活ができず、出稼 き。稼ぎ。内械に徒事している。昭和39年に、爱湲県の共同保健計画 にもとブく为|回の祘モデル地区診断が実施された下大野地区の地区ぐる

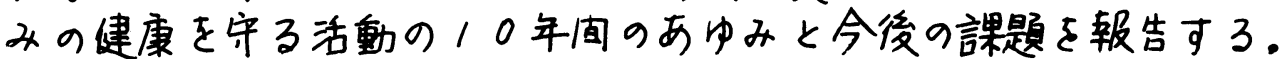

（受診状况）住民自身が自分透の健康状態走点模するとともに、地区ぐ るみの健康を守る活動の具体的な指針去つくために、20 入以上9全住 民文対象に、年1回の健康診断走实施している。受診率の推移（表／）は 昭和41年9健康診断では60\%をわった。しかし、地区組緎である健康 会議が昭和41年12月に発足して以来、受診率はしだいによくなり、昭 和 44 年以降は、80\%維持している。:れは。住民が年1回の健康診 断を必要とするようになったものと評洒、れる。

表1年次别受診率及び有病率9推移

\begin{tabular}{|c|c|c|c|c|c|c|c|c|c|c|c|}
\hline \multirow{4}{*}{ 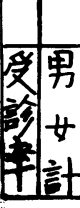 } & S. 39 & 40 & 41 & 42 & 43 & 44 & 45 & 46 & 47 & 48 & 49 \\
\hline & $53.6 \%$ & 56.7 & 55.7 & 52.6 & 63.1 & 79.8 & 73.0 & 74.6 & 72.6 & 71.0 & 31.2 \\
\hline & $75.9 \%$ & 65.4 & 61.4 & 76.1 & 80.3 & 80.4 & 84.0 & 86.2 & 84.4 & 84.3 & 86.7 \\
\hline & 65 & 61.8 & 59.1 & 66.2 & 72.8 & 80.1 & 79.1 & 81.2 & 80.5 & 78.6 & 80.2 \\
\hline & $54.9 \%$ & 78.2 & 63.9 & 56.6 & 70.4 & 50.7 & 63.0 & 57.8 & 60.9 & 83.0 & 52.6 \\
\hline \# & $61.1 \%$ & 67.8 & 60.5 & 67.2 & 73.7 & 65.6 & 72.7 & 67.0 & 30.9 & 61.9 & 60.1 \\
\hline & $58.8 \%$ & 71.7 & 61.8 & 63.6 & 72.4 & 59.2 & 68.7 & 63.3 & 66.9 & 58.5 & 57.1 \\
\hline
\end{tabular}

(有病事)

有病率の推移は。昭和48年〜 49年やや減少の候向がうかがわれるが 著明な改善とはいいがにい状況である。

(疾病像) 表2疾病順位

\begin{tabular}{|c|c|c|c|c|c|c|}
\hline 順位 & 昭和 39年 & 41 & 43 & 45 & 47 & 49 \\
\hline 为1位 & 高血圧 $28.5 \%$ & 高血压 29.8 & 高血压 32.1 & 高血圧 37.2 & 高血压 28.4 & 高血圧 26.7 \\
\hline 中2位 & 箊骨9疾患. 5.4 & 皦骨被 9.8 & 领 31.2 & 血 30.7 & 血 23.5 & 第骨疾急 24.4 \\
\hline 为 3 位 & 旰疾患 4.2 & 肝疾患 & 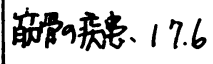 & 胃疾患 5.3 & 蝴骨9疾患.19.1 & 血 128 \\
\hline
\end{tabular}

主な疾病は，高血圧。㝠血。崩骨格系の疾患。胃疾患などである。特に 高血圧が受診者の30\%近くもあり。めだって减少する傾向はみられだヴ。 しかし、領血はやや減つてきた。荕骨格系の疾患は堌可候向にある。 
（潜在疾病水山）

潜在疾病米山推移をみる

と（四1）年口完全治湶型が 增加し、気でかず型の娍少が みられる。

\section{（国保医療統計）}

国民健康保除の医瘏統計走 みると、受診件数ののびを。 昭和40年走100として下大 野地区と全町とを比較したが 昭和 43 年以降は、下大野地 区が全町に比し、はるかに高 〈なっている。(因2) 1人当

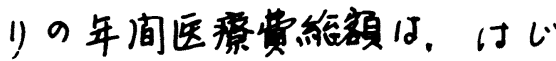
めは下大野地区の方が全町に 比して高かつたが、昭和46 年以降は送転してふり、潜在

因1潜在疾病水山

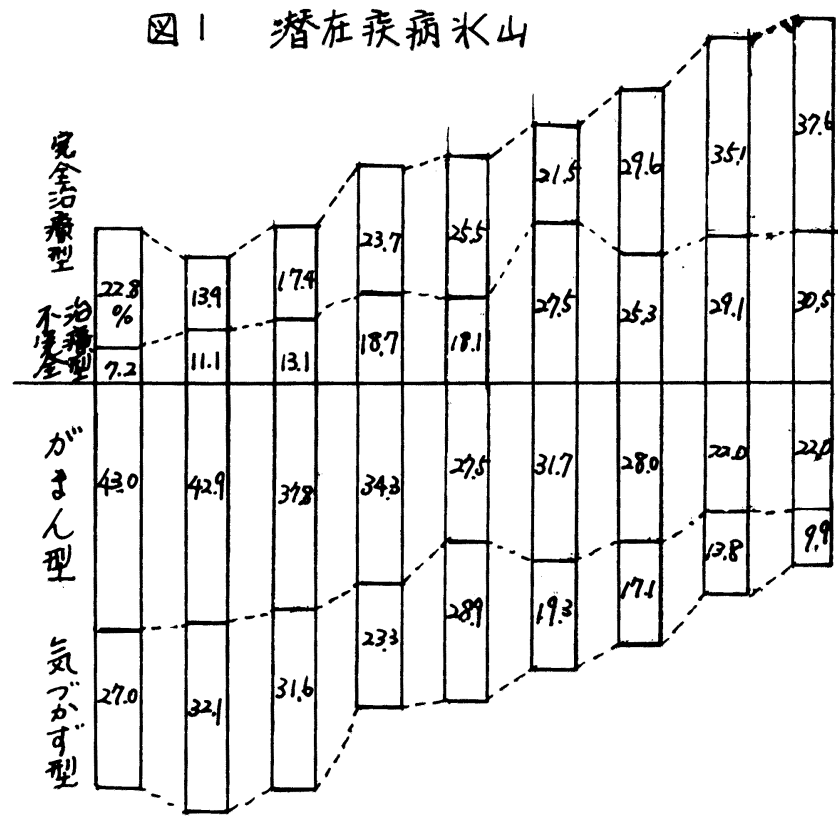

$\begin{array}{lllllllll}541 & 42 & 43 & 44 & 45 & 46 & 47 & 48 & 49\end{array}$ 疾病の隶山の推移と統合すると、疾病の早期発見。早期治病が微底しいじ めたことを示している。

因2地区别受部件数9年次推移
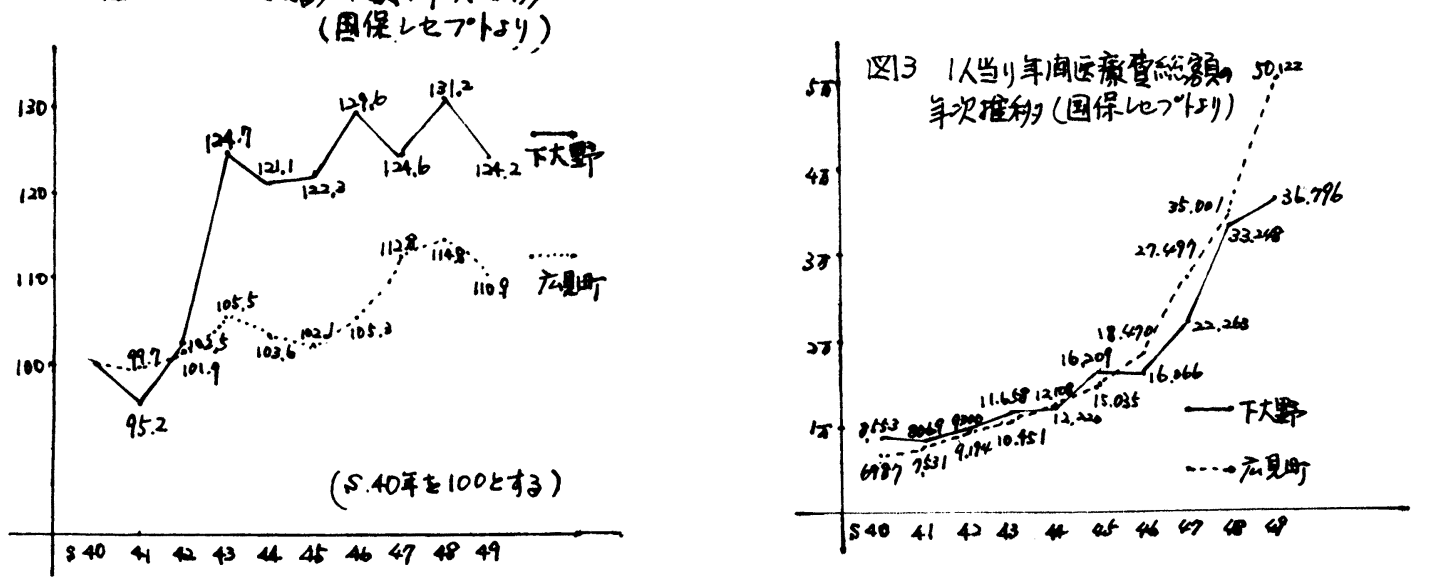

(今後の課题)

1.下大野地区9健康管理活動の 全町への波及の推進 2.共同保健体制の強化 3.健康会議の育成強化 4.保健培伀真9增員
表3 保健径生担当者9推积(広見町)

\begin{tabular}{c|c|c|c|c|c|c|c|}
\hline & 543 & 44 & 45 & 46 & 47 & 48 \\
\hline 保健謧 & 4 & 4 & 4 & 5 & 6 & 6 \\
栄养士 & 1 & 1 & 2 & 2 & 2 & 2 \\
検查技的 & 0 & 0 & 1 & 1 & 1 & 1 \\
径生係 & 2 & 3 & 3 & 5 & 5 & 5 \\
運転手 & 1 & 1 & 1 & 1 & 1 & 1 \\
\hline
\end{tabular}


130. 八千穂村健康管理と国保医㾞费の推移につんて

○井出秀楖、萩原第、饭島郁夫、晹浅道夫、

柳沢正（長野県 - 佐久総合病院）

[はじめ]

八千䅹村で健康管理をゃるようになつた一つのけい機として、国保の医療费半 皟現金空口支払の問題があ万。その空口徽収反対遇動の中から、村民の健康を守 ろらといら村長の考えと私たちの「治療より予防を」とい 与考えが一致して、几千䅹村全村健康管理が開始された。

[研究結果及び考察]

今年で】7年目になるが、全村民飞年1回の健康診断と 同時に村民に対する予防医学的啓蒙活勤を行つてきた。健 康管理の年間計画と活動内容は、ます11月下旬から一者 検診が始まり、23 部落をまわつて大体4月上旬まで続く。 それと殆んど同時に検診で要精検といわれた人達の検査か 行われる。そして部落ごとに報告会を行い、4月頃より村 の保健骕と一粕飞家庭訪問、生活指導、健康相談を行つて

表|健康管理の年間計画

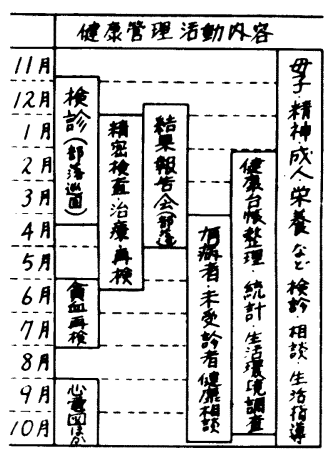

んる。（表】）てれが年間のスケシニールて あるが、健康管理はただ 1 回の検診だけで終つ てはならす、年間を通しての活動が必要である。 次に検診料の年次的推移を見乃と、5 年前は

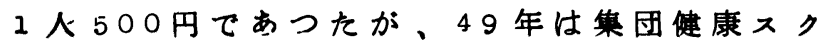
リーニンク方式に切替えたのて11人 2,800 円 と古り個人負担が500月、村の負担が 2,300

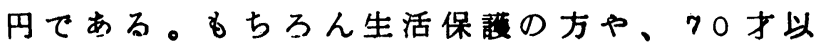
上の方は全額村負担となつている。しかしなが ら検診項目の保险点数と実際の検診费を比較す ると、かなりの開きがててている。（表2） そこで私たちは、健康管理には実際にどのく らんの費用がかかるかを原価計算で調へてみる と、1人当り 4,630 月、総頖 $9,645,000$ 月 なり、検喰料1人当り2,800円でまか子えるは すはなく、病院にとつて大を角担となってい 万。(表 3 )

ては、几千楆村における健康管理费の支出額 は総額 8,700,000円で。人口約 5,300人の村 にとつて決して多い額とはんえない。（表は）
表2. 柃部料(从当り)の年次的变動

\begin{tabular}{|c|c|c|c|c|c|}
\hline \multirow[b]{2}{*}{ 年妾 } & \multirow[b]{2}{*}{445} & \multirow[b]{2}{*}{46} & \multicolumn{3}{|c|}{ (位: A ) } \\
\hline & & & 47 & 48 & 49 \\
\hline 认ด屑担全 & 150 & 200 & 200 & 300 & 500 \\
\hline 村の角担全 & 350 & 450 & 500 & 700 & 2,300 \\
\hline 咭 & 500 & 650 & 700 & 1.000 & 2,800 \\
\hline 保除数 & 1,280 & 1,720 & 1,950 & 2,480 & 8.110 \\
\hline
\end{tabular}

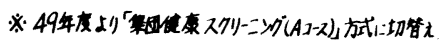

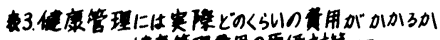

\begin{tabular}{|c|c|c|c|}
\hline & 精 说 & 人当》 & 龟用内客 \\
\hline 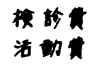 & $\begin{array}{r}6.155,692 \\
999.813 \\
\end{array}$ & $\begin{array}{r}2.955 \\
475\end{array}$ & 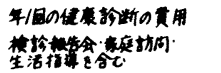 \\
\hline 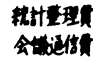 & $\begin{array}{r}2.038 .268 \\
264.444\end{array}$ & $\begin{array}{l}979 \\
127\end{array}$ & 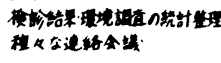 \\
\hline 耣送宾 & $\begin{array}{r}117.140 \\
79,590\end{array}$ & $\begin{array}{l}56 \\
38\end{array}$ & 极的使料 \\
\hline 言 & 644.947 & 4.630 & \\
\hline
\end{tabular}

表4.八千稳村心おけ子健康管理贯の支出額

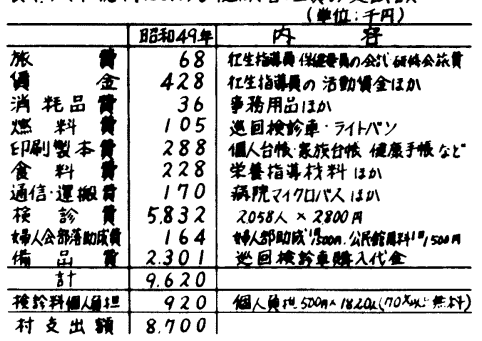


次飞国保の受診件数の推移を南佐久7ケ町村の平均と比較してみると、最初の 5 年間は、入千稳村の方かがり多くなつている、しかしその後入院件数は徐々 に低下しており、最近 5 年間は、はつりと 减少している。(因1)

次に国保の医療費はとのように・変つたか、 年間1人当りの国保医療费の変動につんてみ ると、るちろん医療费の絶対類としては、年 内医療费改訂等すあって增加はしているが、 他町村と比らへてみると、最初の5〜6年は

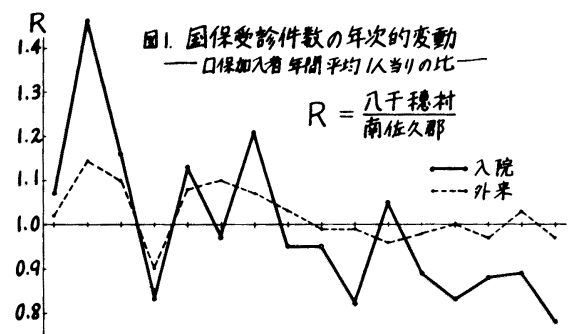

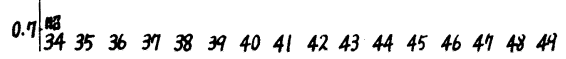
八千稳村の汪のが多くなつているが、その後 次第に下降し、49年ては八千稳村の1人当り年間国保 医療费 30,671 円飞対し、南佐久の平均は40,093 円 で約 9,000円の開音ててているてれを村全体にする と約 30,000,000円の金額とをる。とれをさらに全国 あるいは長野県の国保医療费の年次的推移を比較して みると、やはり初めのらちは八千楆村の方か上まわっ ているか、徐↔に下降してきているてとがかか。

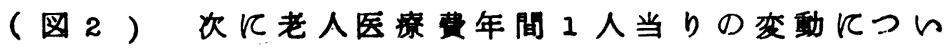
てみ石と、几千秘村の1人当りの老人医療费と南佐久 郡の平均の比較では、その差が48年に25,601円、

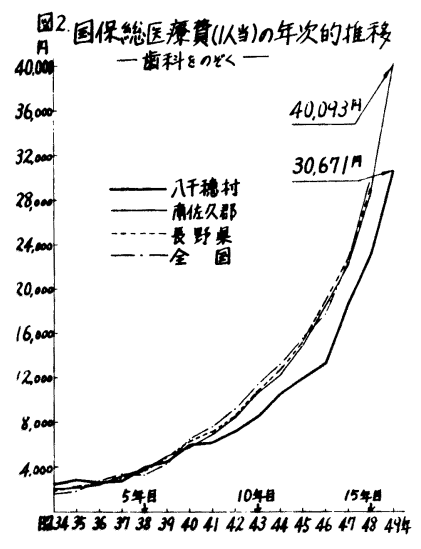
49 年に37,681月と大を開㔔てててい。 (表 5 )

次に 1 人当り国保医療费を。他の健康管理を 実施している地域との比較をしてみると、長野 県の八千稳村は23,350円と取少く、つつい て岩手県沢内村 25,108 月、つ地畏野県島 平26,754 円、岐阜県和良村 26,855 月となっ ている。(四3)

[屯とめ]

八千楆村16年間の健康管理活功は、潜在疾が娍 少したとと、手㜊れが減り、それにょる死亡の減つた てと、脳卒中のなかてる脳出血の娍少かみられたてと などが、その奻果としてあげられているが。また、一 面1人当りの国保医痖费が他町村と比へて著しく減少 した事実は、「予防は治療にまさる」と言のととを実 証していると考える。国や県は早急儿疾病の予防管理 飞対する給付を行らへをである考允る。

表5老人総医療費年間/人当りの变動

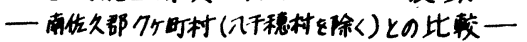

\begin{tabular}{|c|c|c|c|}
\hline & & \multicolumn{2}{|c|}{ （単位：用） } \\
\hline & $\begin{array}{r}\text { 八千稳村 } \\
(A) \\
\end{array}$ & $\begin{array}{r}\text { 南佐久郡 } \\
(B) \\
\end{array}$ & $\begin{array}{l}\text { 差 額 } \\
(B)-(A)\end{array}$ \\
\hline 48 & 94 & 120,105 & 25,601 \\
\hline 49 & 122,223 & 159,904 & 37.681 \\
\hline
\end{tabular}

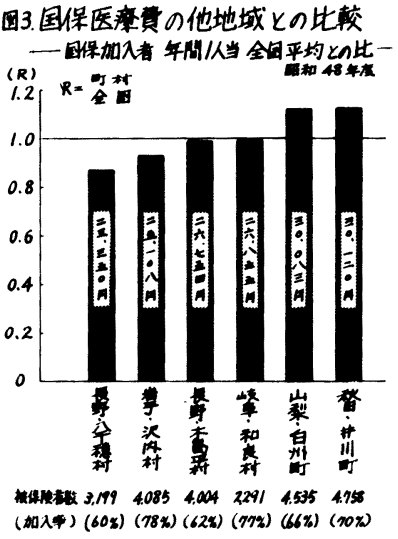


131. 朝日村健康村建設活動10年のあめय

金本 完（信州大・医・公巣）

\section{1. 本活動の基本的な考之方}

村自体による村独自の活動少展用上《てゅく中から、地域集团の健康管

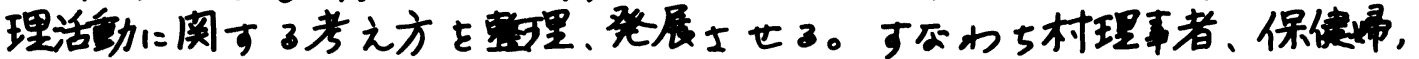

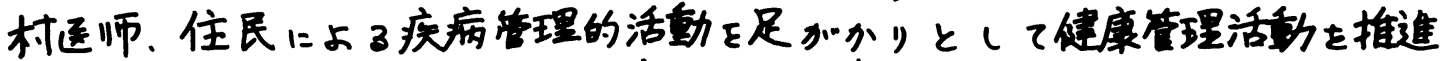

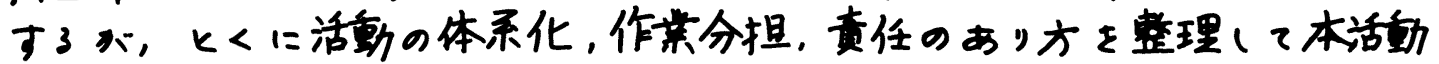
の村行政の中での定着に役立てる。

2、活動の経過

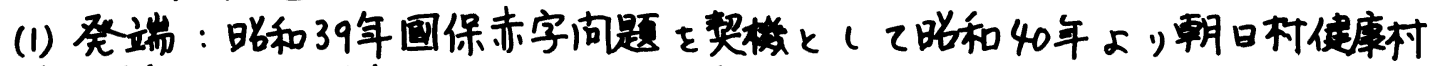

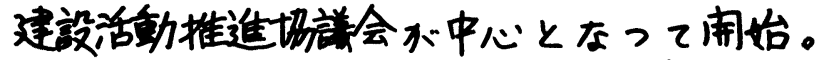

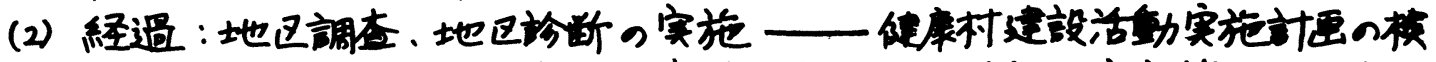

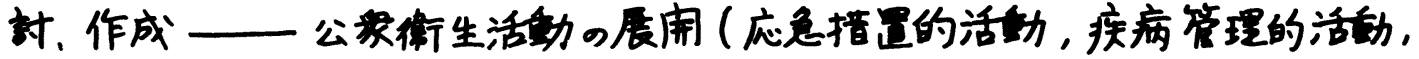

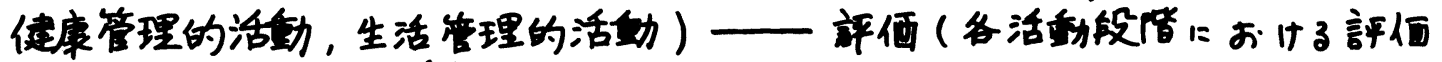
に加之、暗和49年に活勃10年目の绝合的評洒实施)

3、10年间の活動を通してみう水た成果の若干について

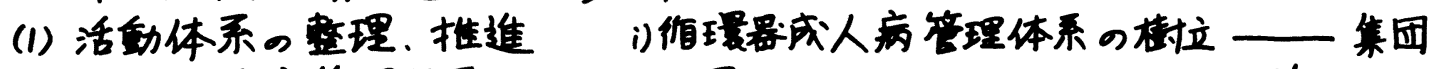

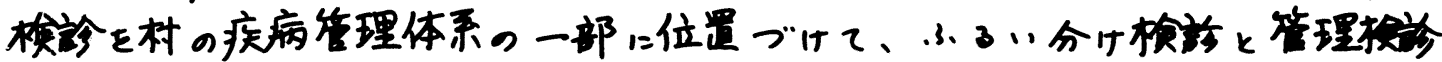

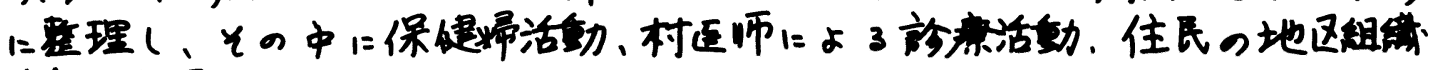
呿をを体系っ゙リた。

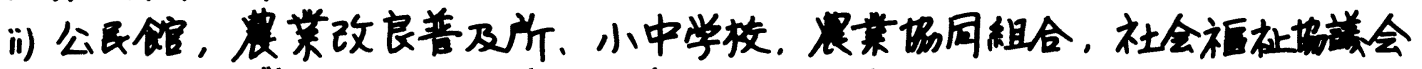

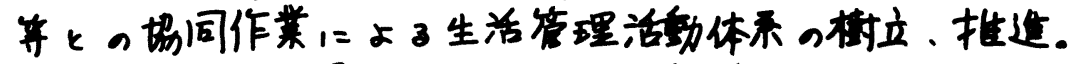

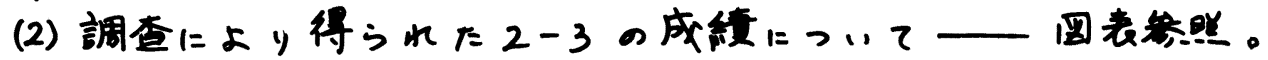
4. 活彭の今後のすすの方

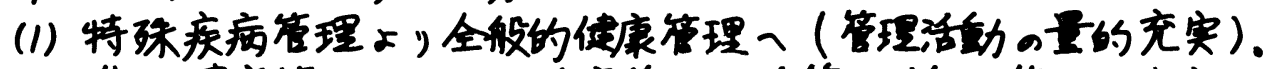

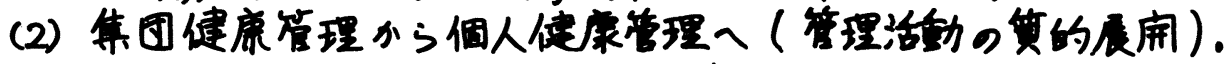

（3）受動的活钦上”主体的活勒几日枟块。

表一， 胋杂中発生状况

\begin{tabular}{c|c|c|c} 
年次 & 74オ以下 & 75朾上 & 計 \\
\hline 恠 38.39 & 21 & 4 & 25 \\
40.41 & 31 & 16 & 47 \\
42.43 & 27 & 20 & 47 \\
44.45 & 9 & 11 & 20 \\
46.47 & 6 & 3 & 9 \\
48.49 & 9 & 1 & 10 \\
\hline
\end{tabular}

表一2 腃卆中に上了死亡状况

\begin{tabular}{c|c|c|c} 
年次 & 74 以下 & 75オ以上 & 計 \\
\hline 暗 38.39 & 20 & 11 & 31 \\
40.41 & 18 & 14 & 32 \\
42.43 & 21 & 22 & 43 \\
44.45 & 12 & 19 & 31 \\
46.47 & 16 & 7 & 23 \\
48.49 & 17 & 18 & 35 \\
\hline
\end{tabular}



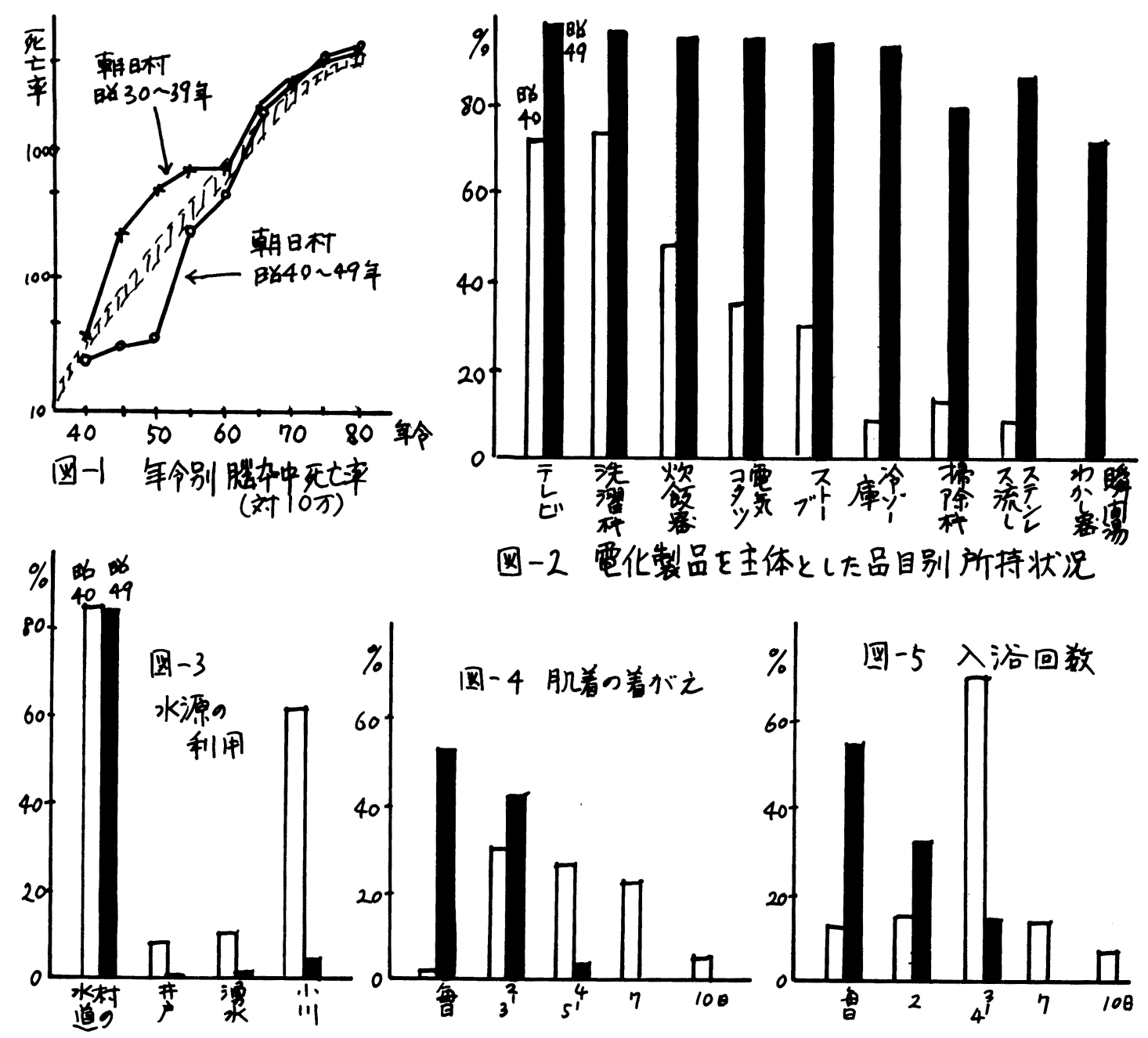

因一生要化製皿を主体とした㽞目别所持状况

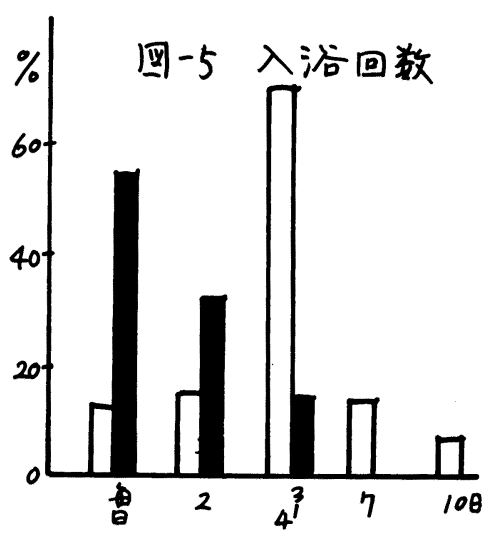

\begin{tabular}{|c|c|c|c|c|c|c|}
\hline \multirow[t]{4}{*}{ 表-3 } & \multirow{3}{*}{$\begin{array}{c}\text { 輣日村k } \\
\text { 隣接村の时 } \\
\text { 政比較 }\end{array}$} & & 面皘 $\left(\mathrm{Km}^{2}\right)$ & $人 Q^{\prime}$ & 剘政力指数 & 経常收支比率 \\
\hline & & 朝日村 & 70.4 & 4220 & 0,130 & 67.8 \\
\hline & & A 村 & 27.1 & 4945 & 0.181 & 67.8 \\
\hline & & B 村 & 59.2 & 8866 & 0.367 & 70.3 \\
\hline
\end{tabular}

表-4 国民健康保 险の实態。

(ar 42)

\begin{tabular}{|c|c|c|c|c|}
\hline & 朝日 & 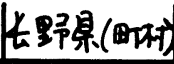 & 长野百(全) & \\
\hline $\begin{array}{l}\text { 受診 率 } \\
\text { | 件当信馀费 }\end{array}$ & $\begin{array}{l}457.2 \\
1.910\end{array}$ & 390.8 & $\begin{array}{l}400.3 \\
2,499\end{array}$ & $\begin{array}{r}388.1 \\
2,665\end{array}$ \\
\hline |人当り診痻 & 8.735 & 9.740 & 10,006 & 10,344 \\
\hline
\end{tabular}

表-5 同

(绝 48)

\begin{tabular}{|c|c|c|c|c|}
\hline & -1 & द地堡 & 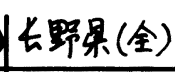 & 全 \\
\hline $\begin{array}{l}\text { 受診 率 } \\
\text { |件当り診冻费 }\end{array}$ & $\begin{array}{r}58 \\
4,0\end{array}$ & $\begin{array}{l}54 \\
59\end{array}$ & & \\
\hline 人当り文 & 23,584 & 31,273 & 31,6 & \\
\hline
\end{tabular}




\section{城田健夫(别府市鹤見病院)}

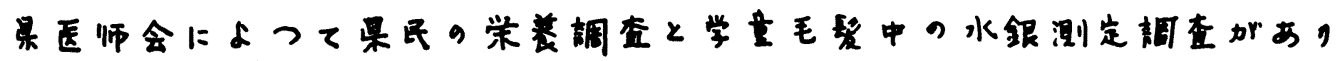

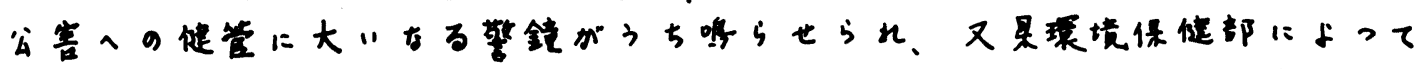

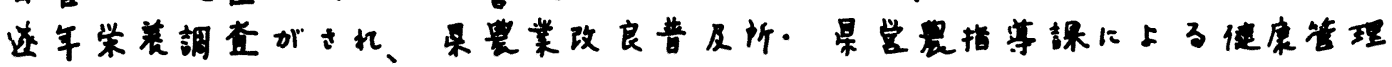
特别事类として12年余に亘了ボークング的户别健康生活指等加行かれて

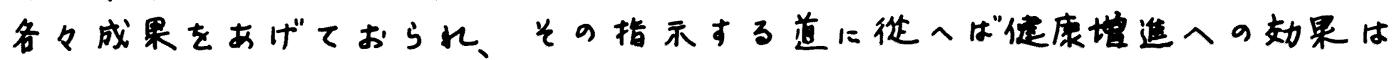
镇いをはさを余地はないと信い゙られる。

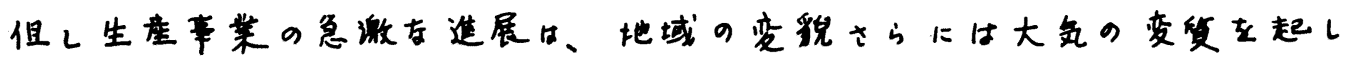

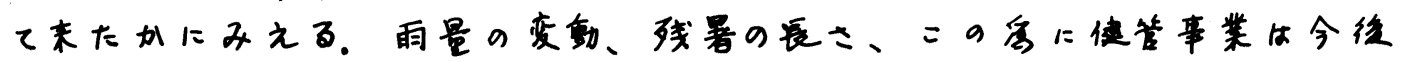

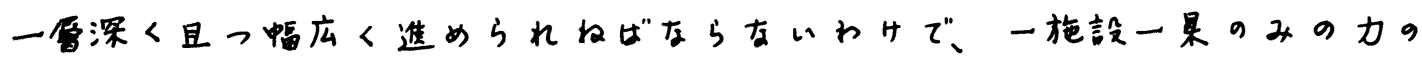

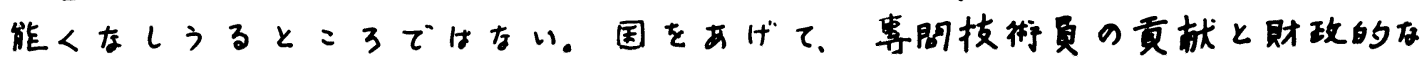
後援の堽大を求めたい。

扱飞私共の施設は昭和制の别府りハビリ施設として昭和18年看

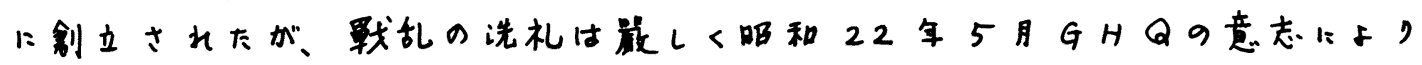

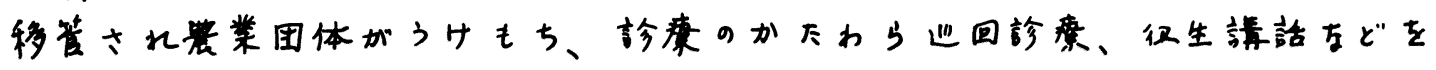
綨けて来た。

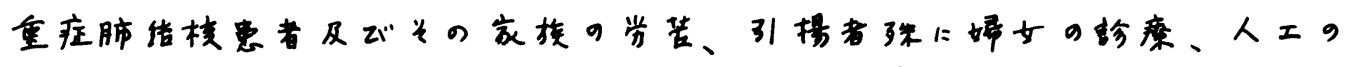

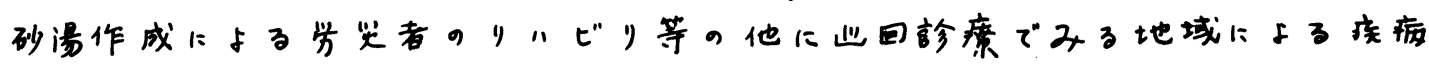
の特異性产舆味深く钼客した。

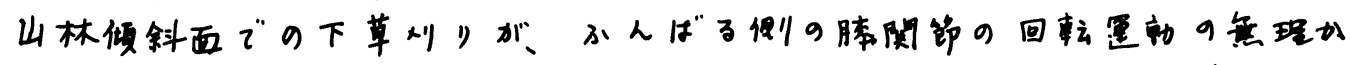

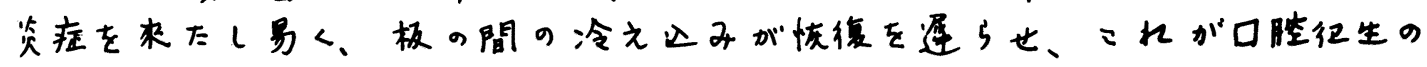

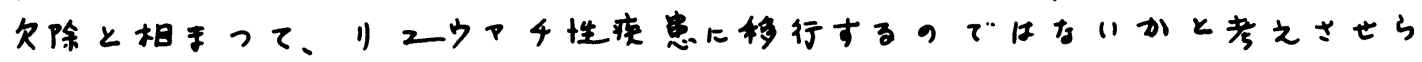
れた時は健康を保つコツといつたものを、かいまみた思いたかられた。

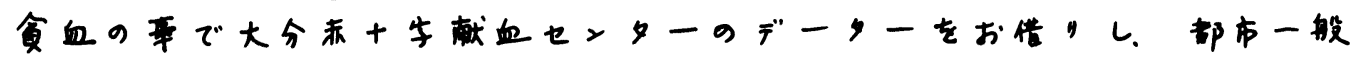

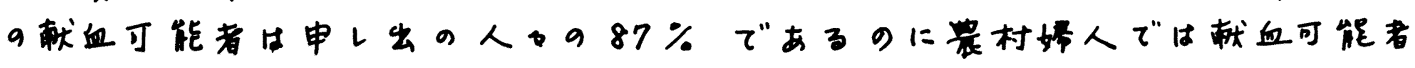

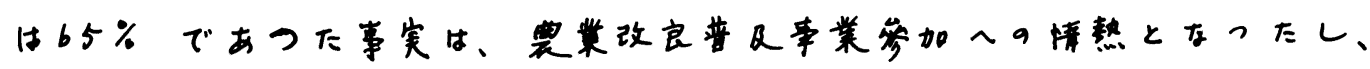

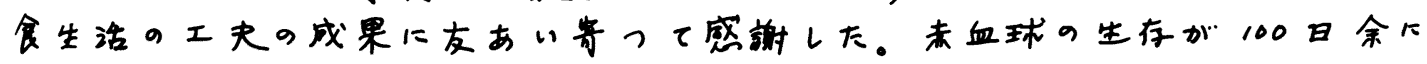

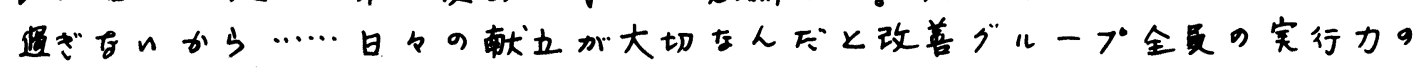
源泉がわれあがつた事もあつた。

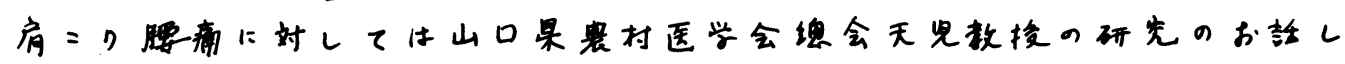

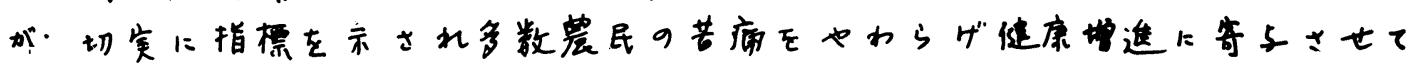

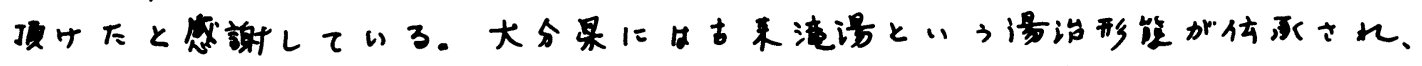

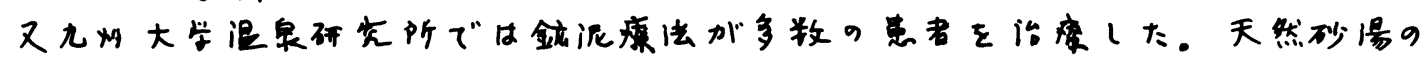

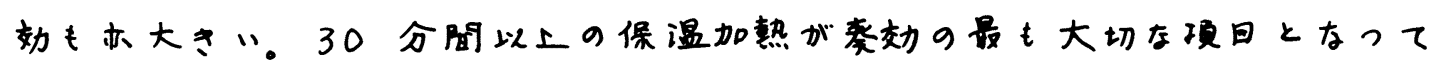




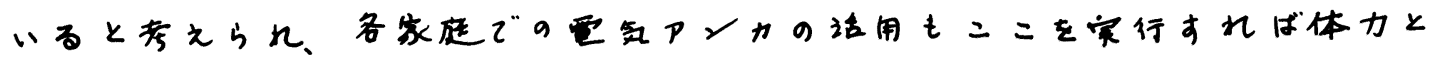
相”手つて奏轩が期待され了。

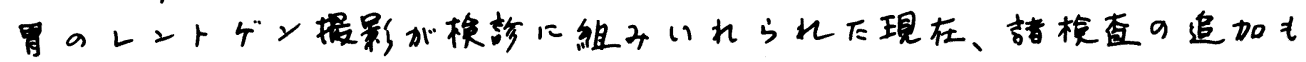
术め的れて巡回检查の限的れたスタフバは果し得なくなった。大分果原生

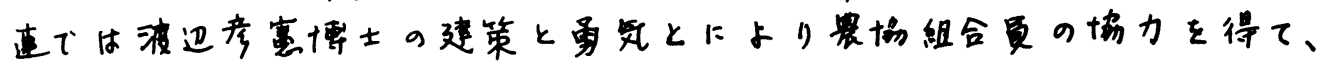

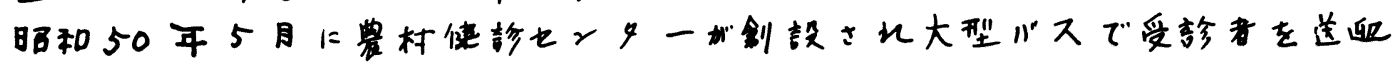
3 時間ドックが発足した。9月现在2700名受噇。

地域别病病厸椎别疾病などの把挃みでに到つてはいむいが

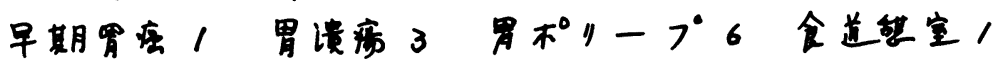

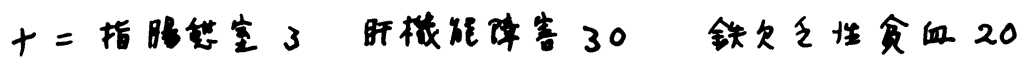

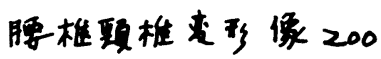

をみている。5000名を超之た時に䋘計值を兴表する子定である。

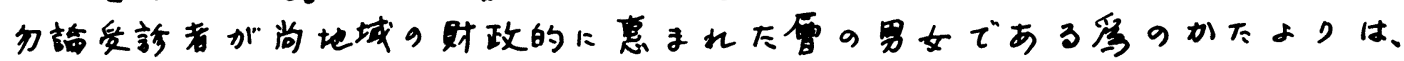

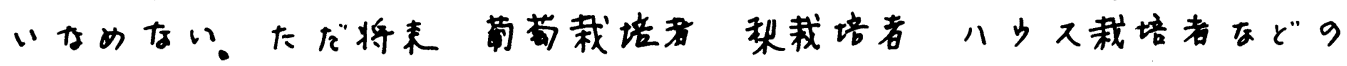

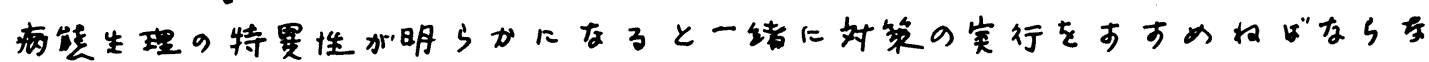

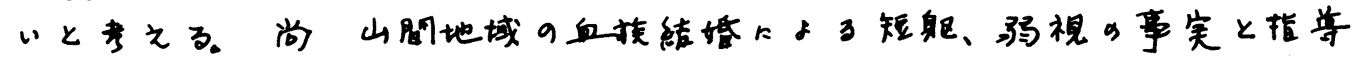

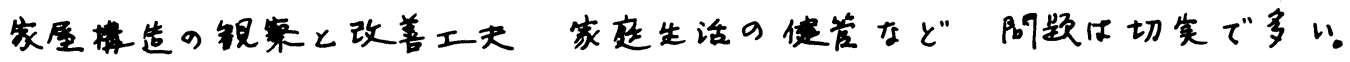


衛生 統計

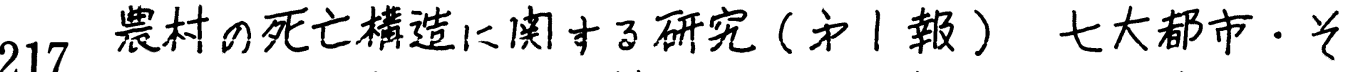 の他の市部との比較からみた郡部死亡の特徵}

\section{江崎廣次（福岡大・医・衛生）}

(目的)農村の死亡構造の特徽を知る目的で七大都市、年の他の市部と 比較しながら統計的解析を試みた。今回は昭和45年の成績を主に報告する

(方 法)基硬资料として厚生省統計情報部編の主要死因别死亡率、械業 座業别人口動態統計、覀性新生物死亡統計を用いた。

〔結果〕昭和45年人口は、七大都市1956 万、年の他の市部5475 万、郡部 2811 万(郡部 $27.3 \%$ ) である。昭35全国人日を基隼にした訂正死亡率は、 とれどれ人口10万䇃560.3、579.5、614.5 である。七大都市を100とし太訂正 死亡率指教を主要死因别に短察すると国 のように、統死亡で12\%の死亡超週 であり、脳血管疾患、不虍の事故、肺关 気管支炎、自殺が多く、ガン、高血圧、 結核、肝硬变汃少ない。表|には七大都 市にくらべた死亡增减を示した。郡部の 死亡超通は、期待敖にくらべて男/2.700、 女6700であり、この超過の多いものは、 男女と者脳血管疾忠、不虑の事故が目立 ち、一方少ないものは、がン、虚血性心゙ 满病、高血圧、肝硬变などであつた。 因2で性别、主要死因别、年令别に険討作。

〔むすび〕郡部は七大都市にくらべ全年 令栺級とも死亡超過であり、特に25一 29 才では58\%超過、二北は膇血管疾忽、不 虑の事故が吕の主因である。

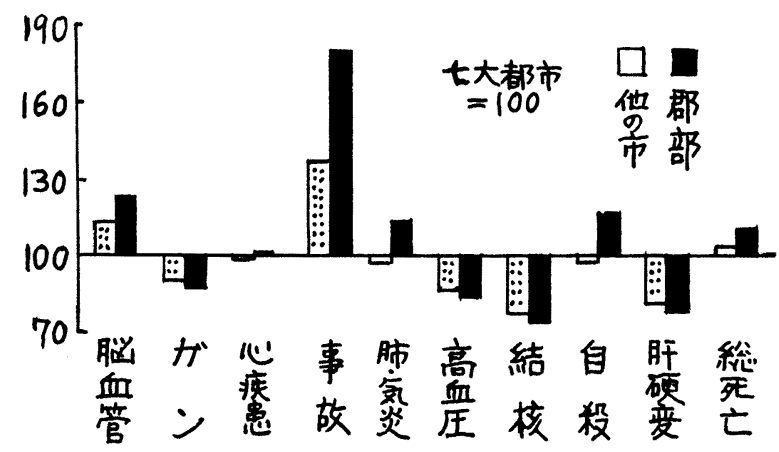

图1. 訂正死亡率指敖 㽖計 昭45

表| 死因别訂正死亡事指教 およで死亡增減 七大都市 $=100.545$

\begin{tabular}{|c|c|c|c|c|}
\hline \multirow{2}{*}{ 死 因 } & \multicolumn{2}{|c|}{ 男 } & \multicolumn{2}{|c|}{ 女 } \\
\hline & 指教 & $0-E$ & 指敖 & $0-E(E$ \\
\hline $\bar{z}$ 死 & 112 & 127 & 107 & 67 \\
\hline 核 & 73 & -13 & 77 & -5 \\
\hline 全がン & 89 & -39 & 87 & -26 \\
\hline & 97 & -5 & 94 & -5 \\
\hline 帕 & 70 & -10 & 71 & -4 \\
\hline 乳房 & & & 83 & -4 \\
\hline 子宫 & & & 57 & -5 \\
\hline 白血病 & 100 & 0 & 97 & 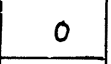 \\
\hline 糖尿病 & 78 & -5 & 100 & 0 \\
\hline 心疾忠 & 101 & 3 & 100 & -1 \\
\hline 虚血性 & 87 & 12 & 83 & -13 \\
\hline 血圧 & 86 & -5 & 86 & -6 \\
\hline 脑血管 & 124 & 71 & 19 & 52 \\
\hline 帅気管支炎 & 112 & 4 & 12 & 5 \\
\hline 消化溃癌 & 119 & 3 & 107 & 1 \\
\hline 肝硬变 & 75 & -8 & 87 & -2 \\
\hline & 136 & 5 & 14 & 12 \\
\hline 不䖘の事故 & 183 & 51 & 51 & 12 \\
\hline 自動事 & 194 & 26 & 149 & 4 \\
\hline 溺 死 & 266 & 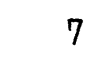 & 425 & 4 \\
\hline 殺 & 118 & 4 & 131 & 2 \\
\hline
\end{tabular}




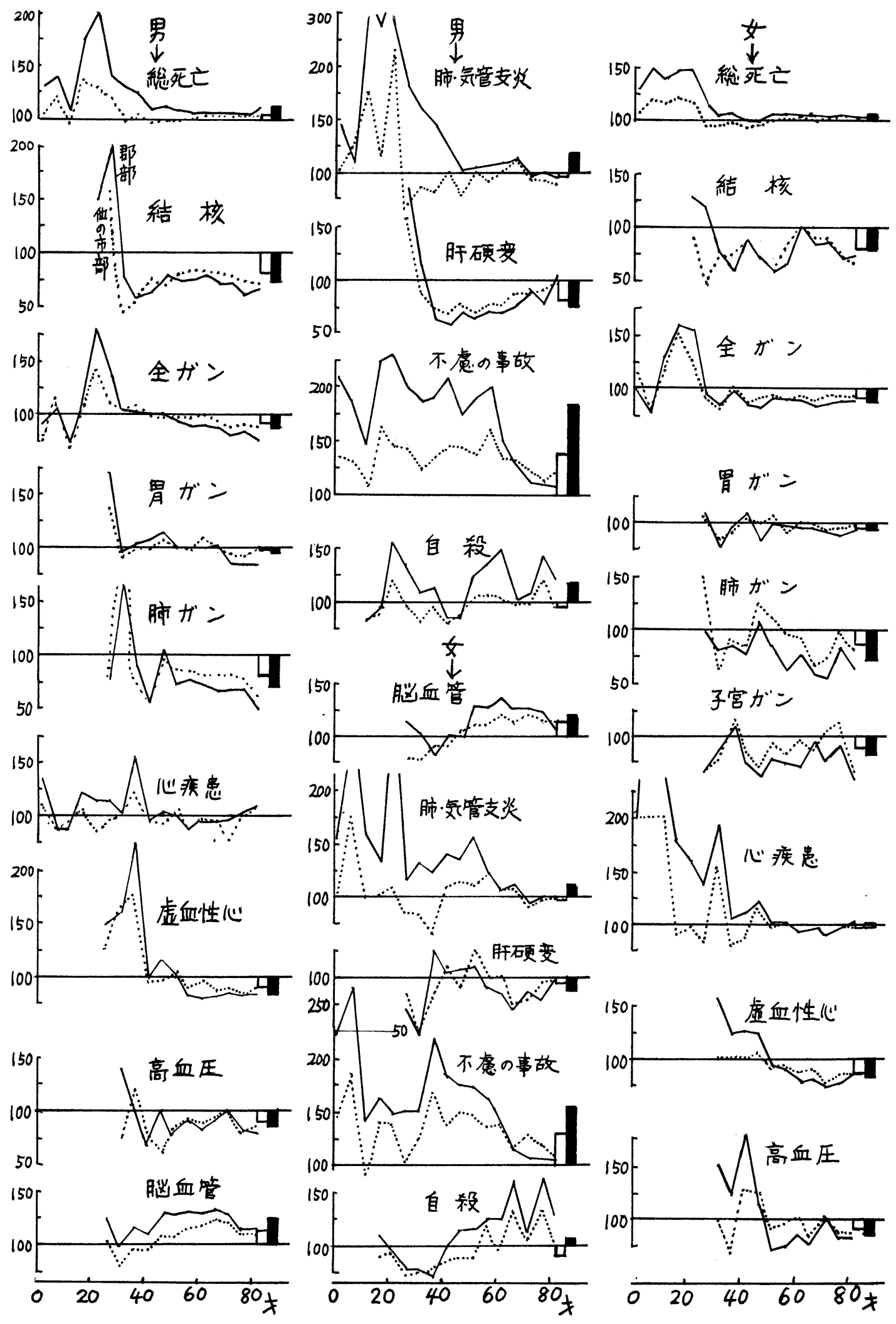

図2 訂正死亡率指敖男女别·年令别昭45. 七大都市 $=100$ 


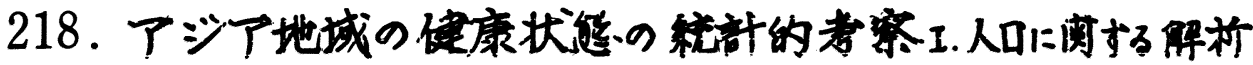

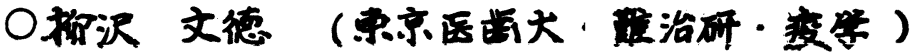

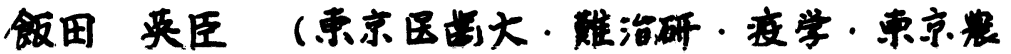

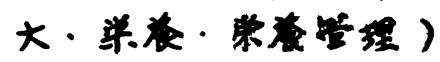

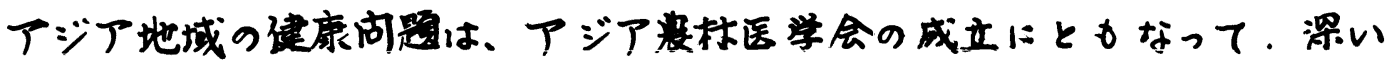

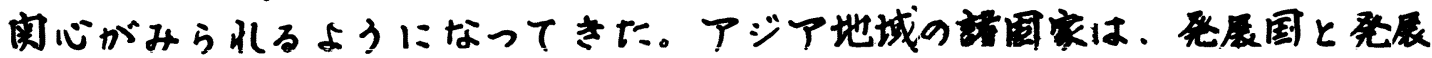

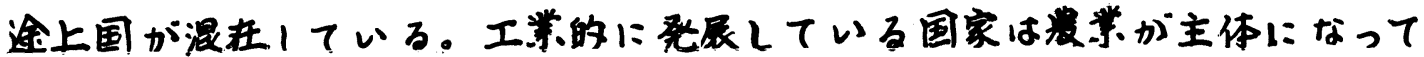

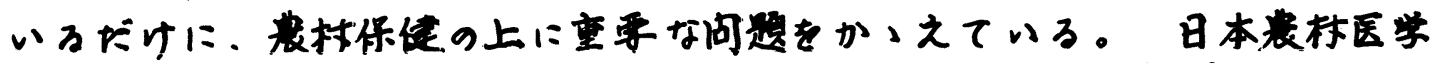

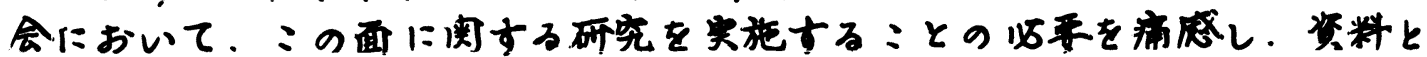

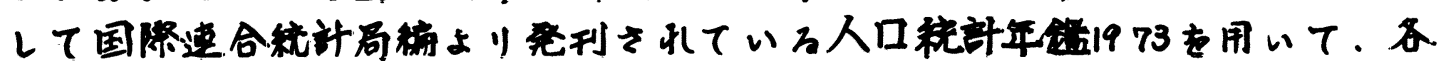
国家の相连を分析すべく研究を用始したが、今回は先ず人口9实造根要: ついて教告する。

\section{表1国名上事号の阅你}

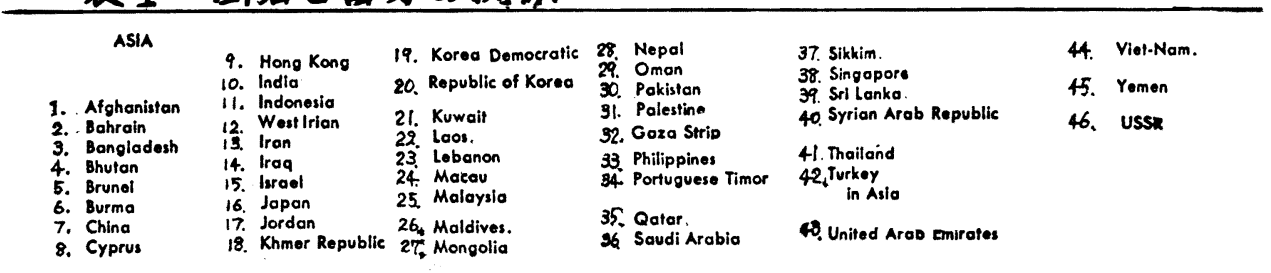

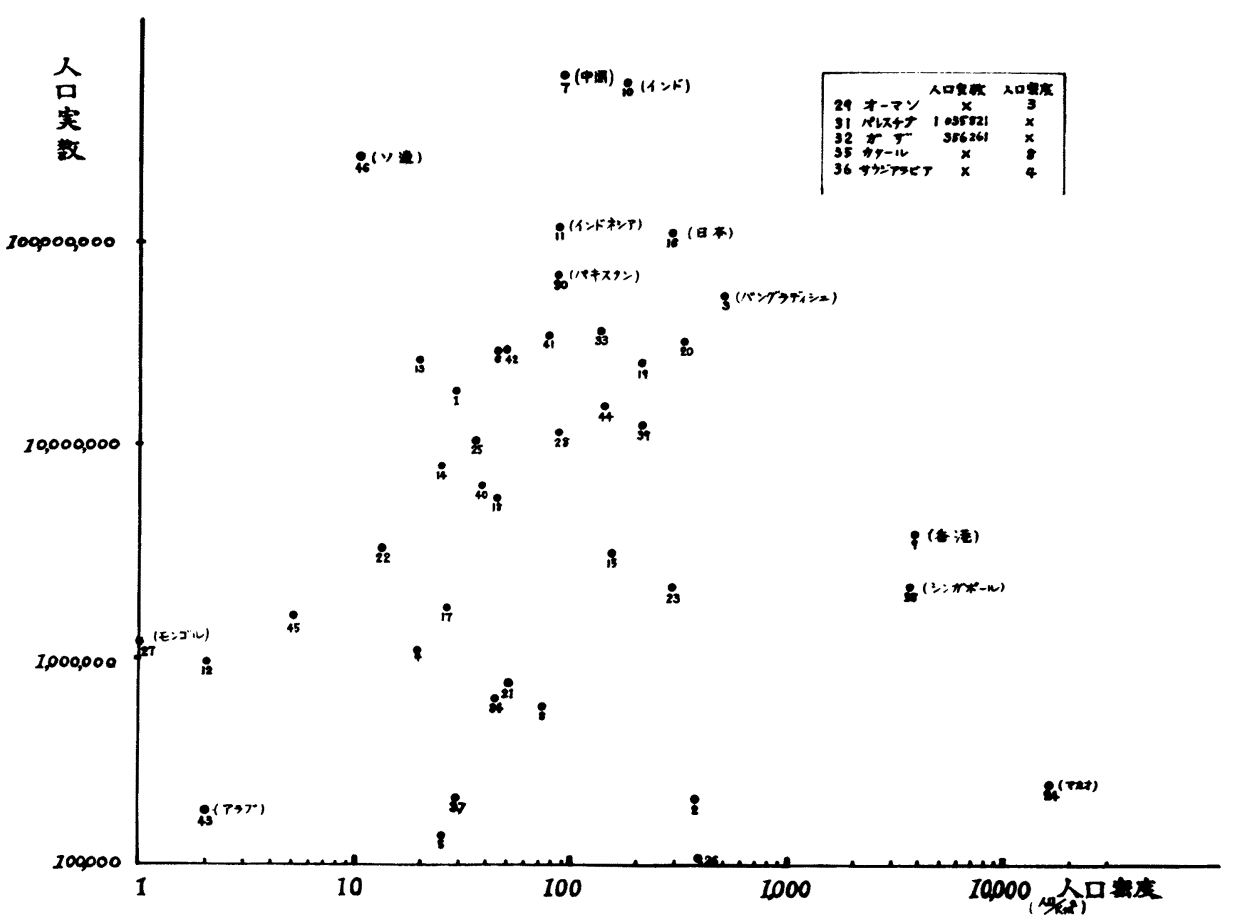




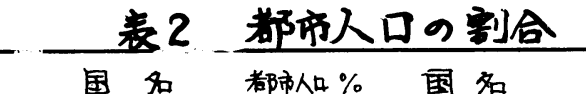

\begin{tabular}{|c|c|}
\hline fahani & Iran \\
\hline 2. Bahrain & 78. 1 14. Irag \\
\hline 5. Brunei & 63.675 . Israel \\
\hline Cyprus & 43. 1 16. Japan \\
\hline dia & $20.2 \%$ Jordan \\
\hline onesia & 17. 5 20. Korea, $\operatorname{Re}$. \\
\hline (ri & 16.2 \\
\hline
\end{tabular}

都市人 \% 国名
42.6 22. Laos
61.4 23. Lebanon
84.3 24. Macau
72.1 26. Maldives
43.0 27. Mongolia
41.2 28. Nepal
22.130 . Pakistan
都市人口 \%
围名
26.846. USSR

都市人鲐

14.7 33. Philippimes 31.7

60.137. Sikkim 5.3

97.1 39. Sri Lanka 22.4

11.340 .Syrian $\quad \mathbf{4 3 . 5}$

46.4 47. Thailand 13.2

4.0 42. Turkey $\quad 38.6$

59.2

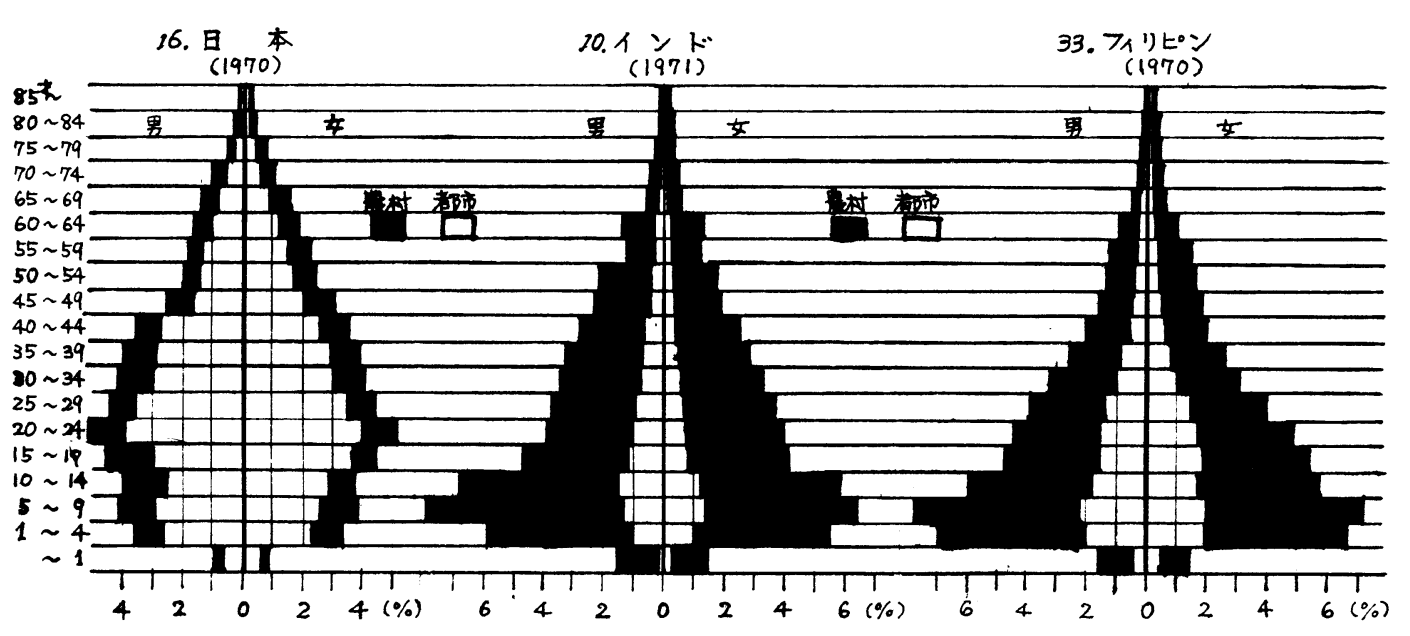

国2人口样成

成精アジア諸国は、国家の统一、分梨などで问题が存するが资料に よった国家は岎の国である。半れにン連をつけて吟味することにした。ま

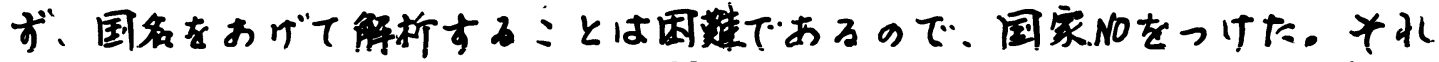

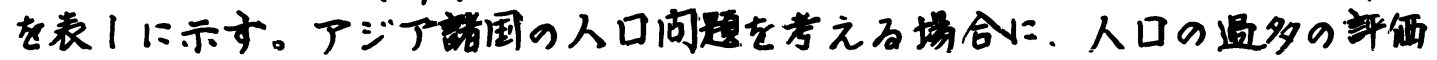

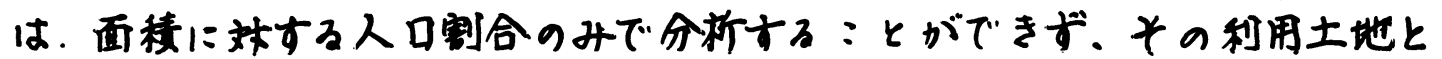

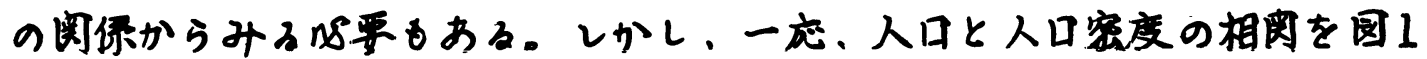
に示しておく、:のような实䑨をふはえて考察する资料としなければなう

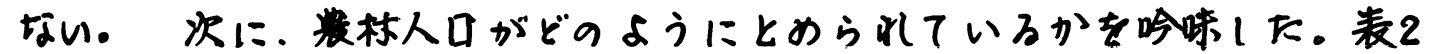
に示す、:玌は都市人口9制合を示しているが、将羍国であるかどろかの 基本的な分析をしてみた。日本は都市人口72\%であるに坟しイラン $42.6 \%$ タイでは13.2\%というよ3である。:の点について国民折得との相成を吟

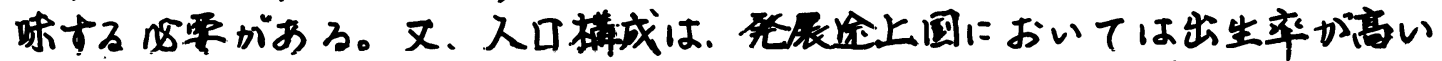
:とからピラミッド型(インド)、出生率低下、死亡产激减の国ではツボ 型で日本はキの代着である。全部について国示する：とができないのでる フの国とした。

まとめアアジア地域国家の实管算析する:とは。アジアの一部に位置レ

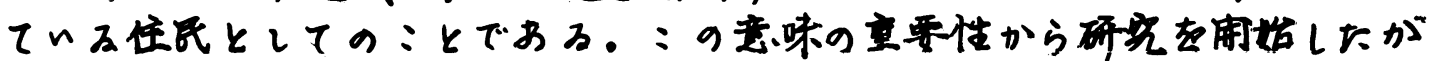

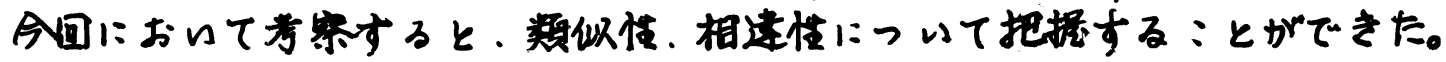


219. 串村媂人の食血の实能，它の社会的背景

肉龍太郎。高椅昭雄（島根累松江保健所）

はビめと

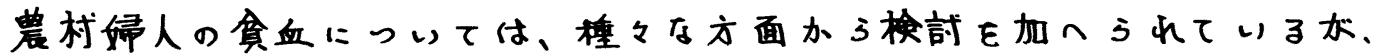

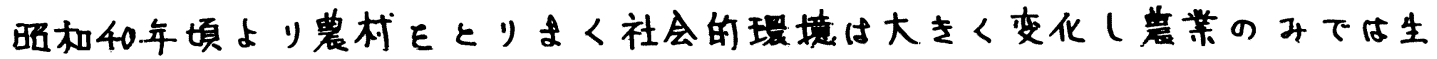

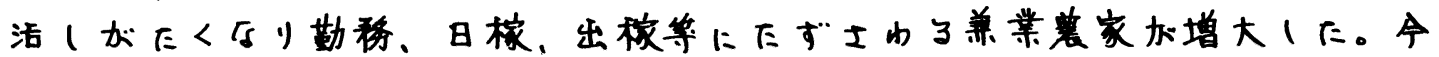

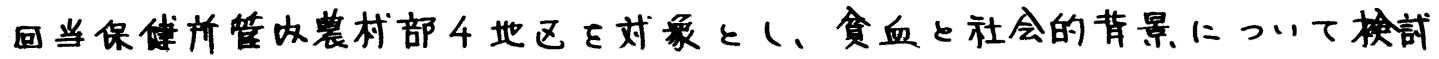
$1 \tau$ 。

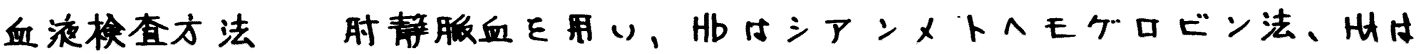
毛細管法で行った。

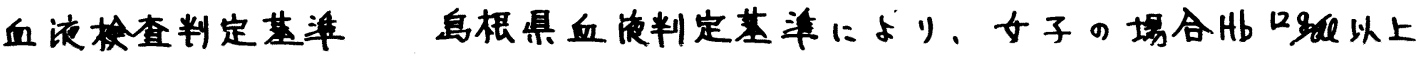
H36\%以上正常值とし，をれ未满と異常值と1に。

刘象地区の概㑆

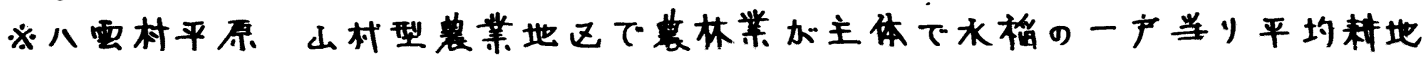

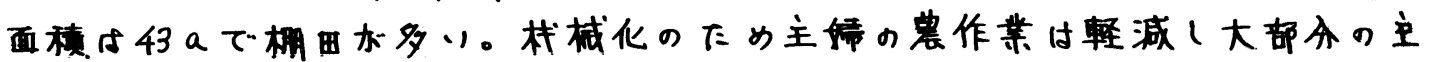

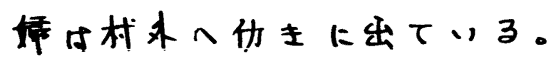

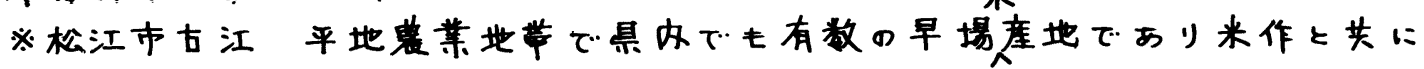

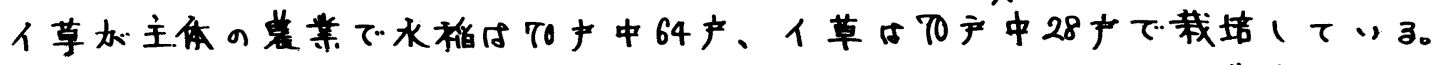

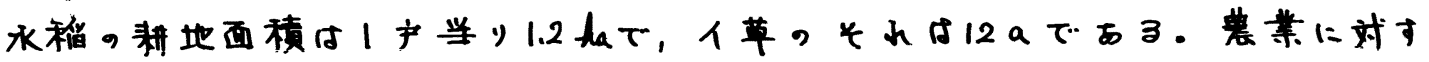

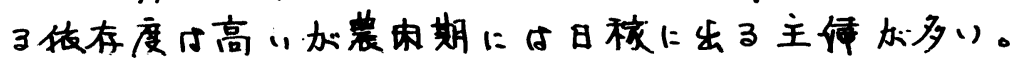

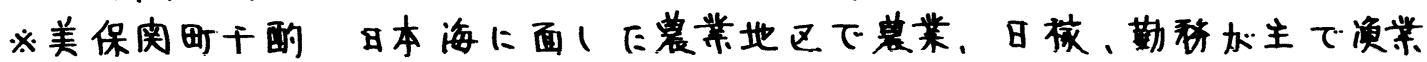

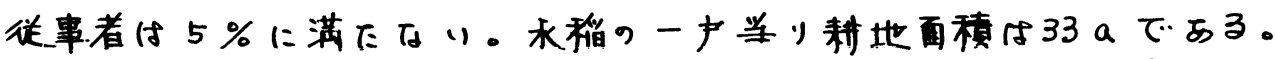

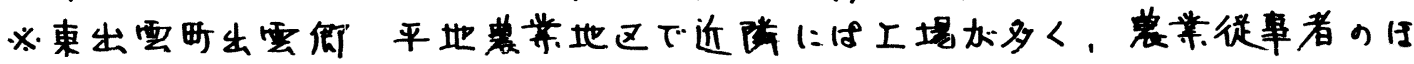

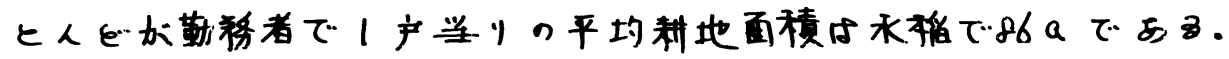

榓業収入について

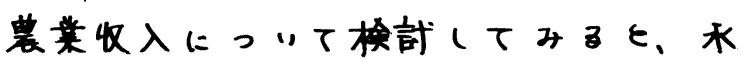

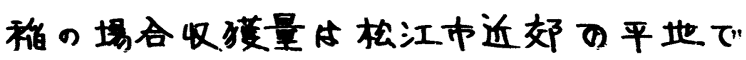
480 kgroa, 山地で411 k9 度政府受上価格は3等米で $30 \mathrm{~kg} 7.800$ 用 表工一当りの木椎による純益

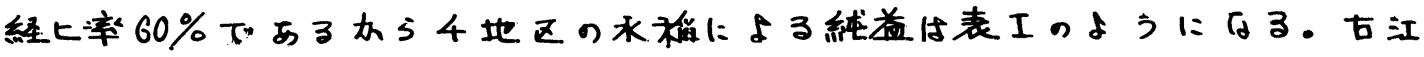

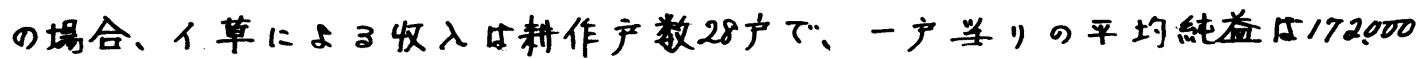
用にする。他地区にふいて指作以外の收入けごく佳である。 
山村型の平原汃低い。团2の年代别異学者来では 全体に30代加高く，40，50，60代と低くなつて”

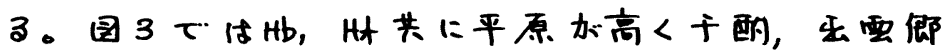
古江の順で低下にている。国4です30代汃低く， $40 \sim 60$ 代に余》差汃的”。

\section{考察}

服和30，40年代9高度经清成長政策，减反政策

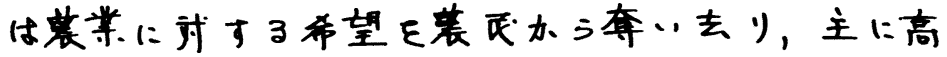

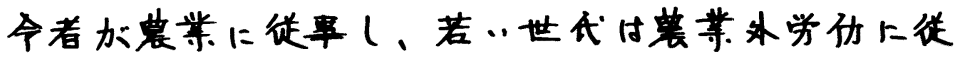

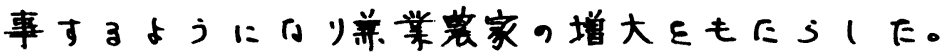

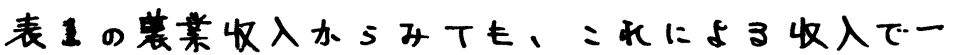

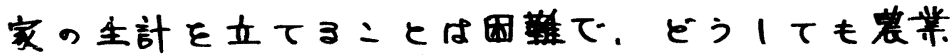

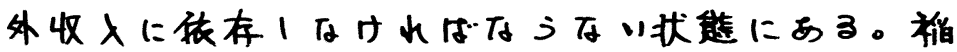

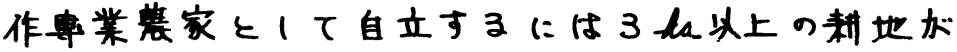

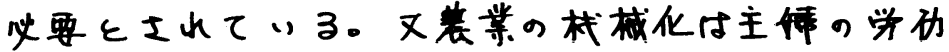
軽堿へっなが二たが：の供却のために办之つて

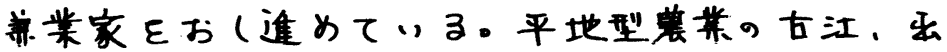
要唧地区で罢常者加多“的料地面槙汃平原，广

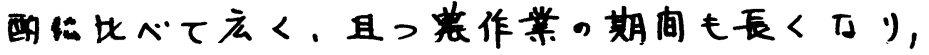
持に古江で、イ草加巨る阅你上徒事日数も長くな

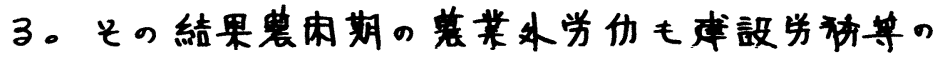

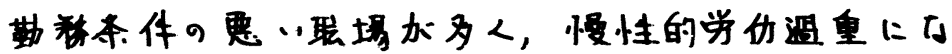
り異常者加多”結果になっていると思わらる。

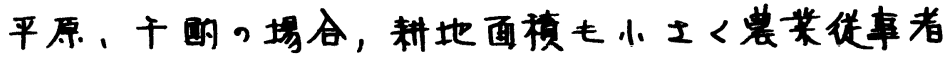
も50，60代加多く30，40代の主作比子部品工场

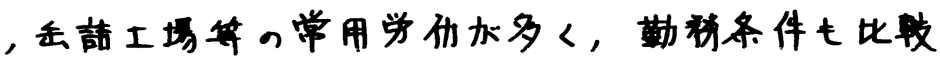

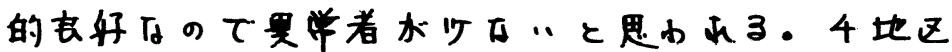

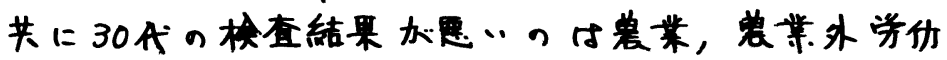
の外に育览，家事等的页担の多く办加年代下゙

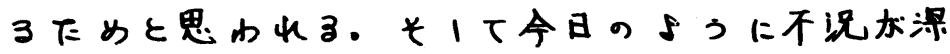

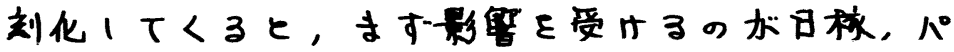
一十等の不安定小座用条件の者でらり基家の多く

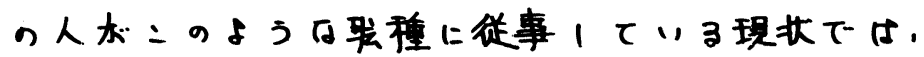
不识と共に璉金收入の低下をもたらし，长のしい

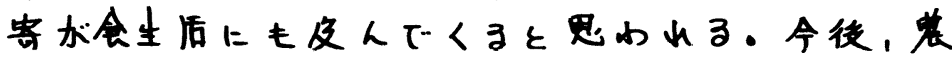

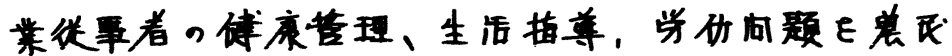
に一番身近な縕絾でらる幕恊がリーダーとなっ丁

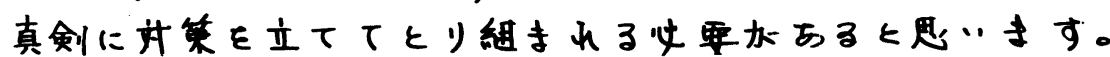

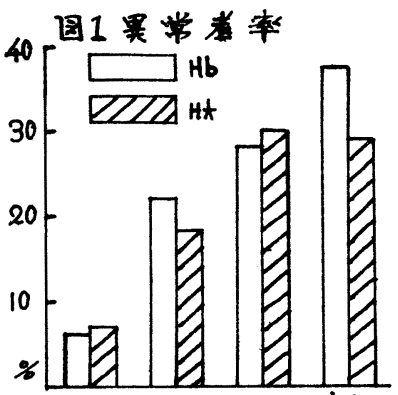

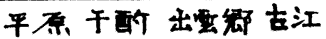
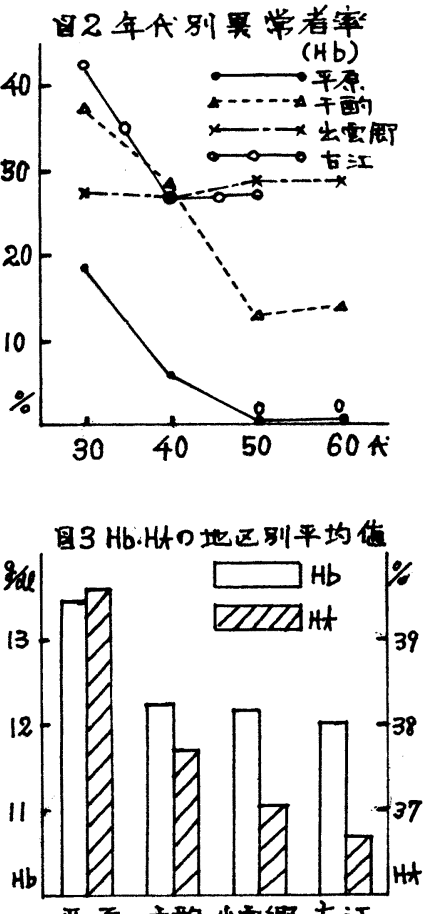

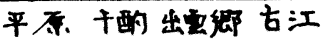

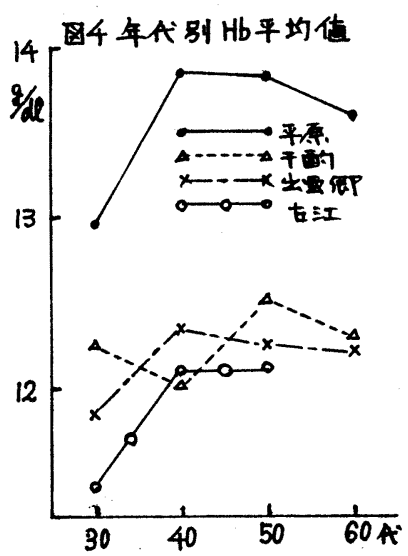


220. 合関する個人的, 社会的青景について

$$
\begin{aligned}
& \text { の小池恵美子宫原伸二吕川テル三浦礼子 } \\
& \text { 土井一美 (秋田具上郎部療所) }
\end{aligned}
$$

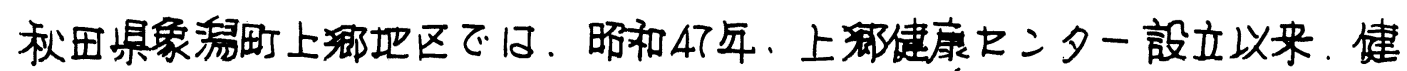

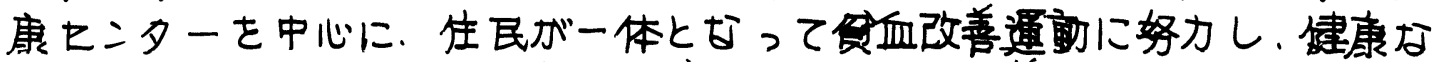
世区作りをめさしてきた。实察，貧血け年ごとに改善を示してきている。

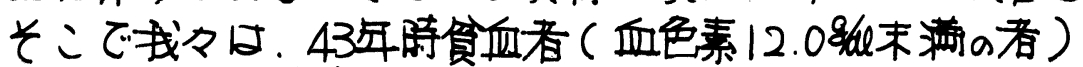
とさ水た者 させ貧血改善の阳寒因子を見いだすとともに，地区内に みら水る部落間の血浓值の格差の原因を透求すべく、買 血改善に関与するであろう们人的. 社会的条件をできる かぎリ多面的に分析し、尚一扈の筧血改善をは心るもの である。

因1血液性状。改善实態(成人)

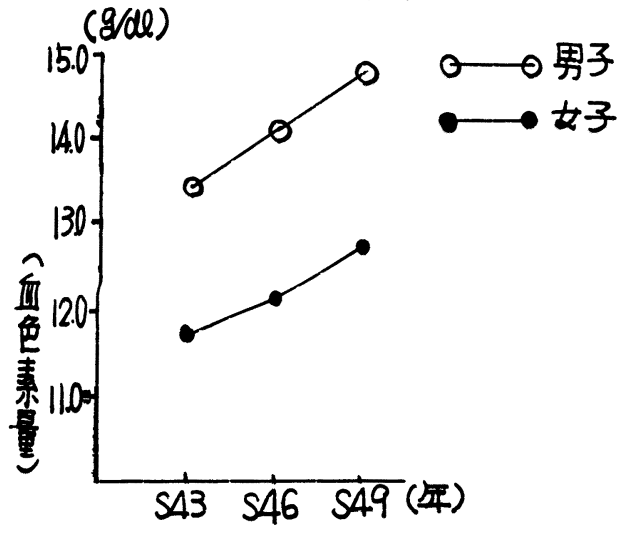

四2 血泿性状。改善实態(小学生) (adele

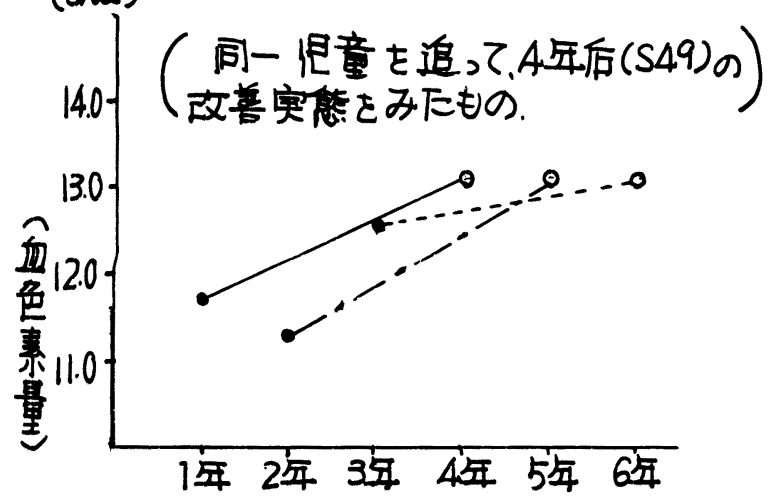

血液值上関才る社会的条件

\begin{tabular}{|c|c|c|}
\hline & 横同部落 & 長岡部落 \\
\hline 血色素平均值 & $12.0 \mathrm{~g} / \mathrm{de}$ & $13.2 \mathrm{~g} / \mathrm{dl}$ \\
\hline 立地条件 & \multicolumn{2}{|c|}{ 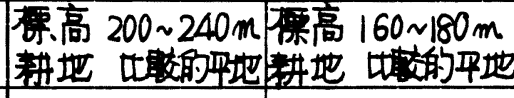 } \\
\hline 平均耕作面视 & $1.40 \mathrm{ha}$ & $1.42 \mathrm{ha}$ \\
\hline 農業形態 & 専啨琹 & 兼業型 \\
\hline $\begin{array}{l}\text { 肉食デー } \\
\text { 利用状況 }\end{array}$ & $27 \%$ & $65 \%$ \\
\hline 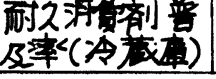 & $80.4 \%$ & $106.8 \%$ \\
\hline
\end{tabular}

表|社会的条件。匹影 (S49)

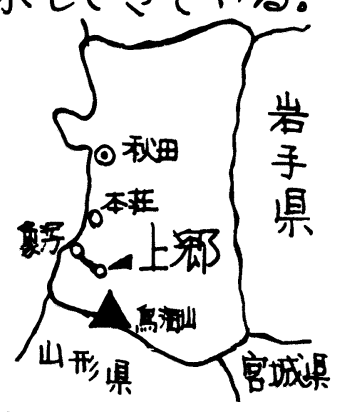




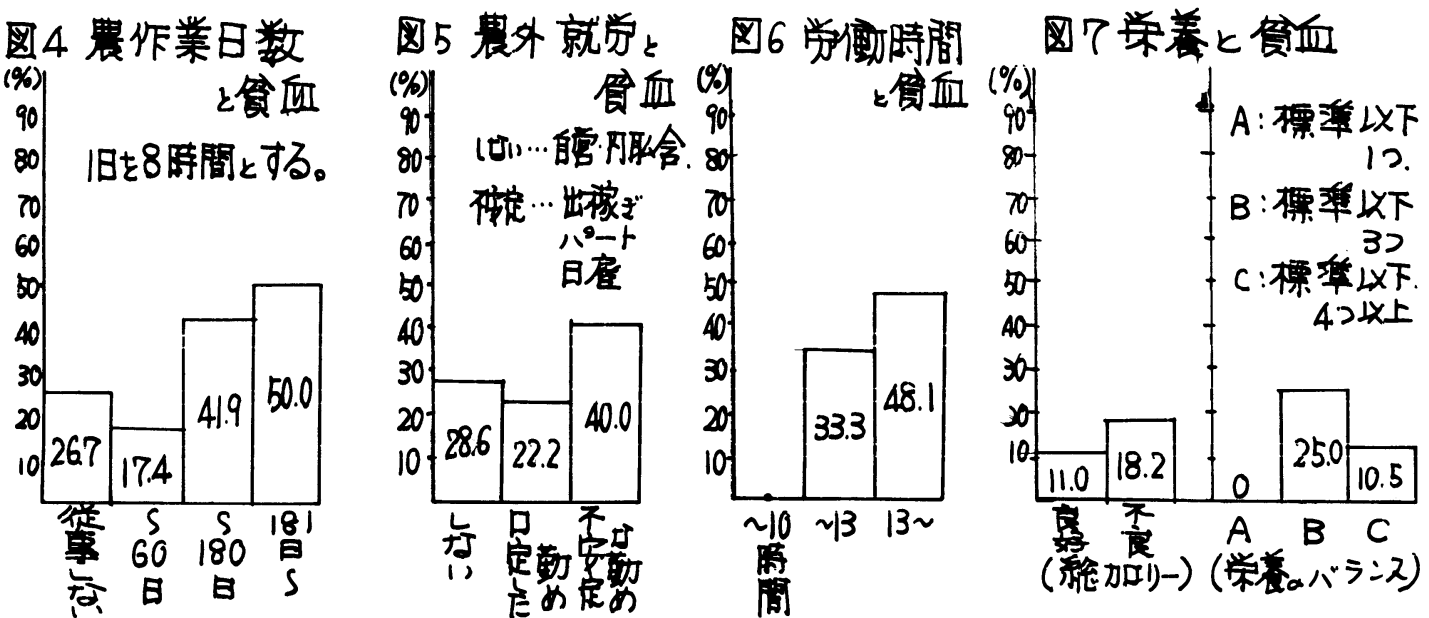

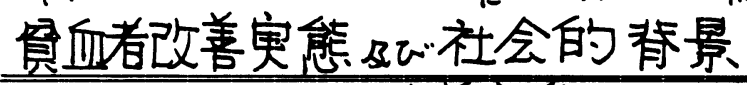

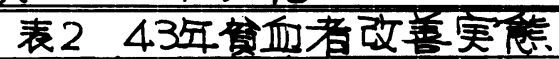

\begin{tabular}{|c|c|c|c|}
\hline & 543 & St & \\
\hline $\begin{array}{r}\sim 9.9 \\
8 / d l\end{array}$ & $10(10.8)$ & $\begin{array}{l}6 \alpha(60.0) \% \\
4(40.0)\end{array}$ & 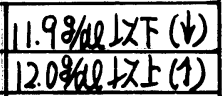 \\
\hline 10.0 & & \begin{tabular}{|ll}
9 & $(47.4)$ \\
\end{tabular} & $\downarrow$ \\
\hline$\sim 10.9$ & $19(20.4)$ & $10 \quad(52.6)$ & $\uparrow$ \\
\hline $\begin{array}{l}11.0 \\
\sim 11.9\end{array}$ & $64(688)$ & $\begin{array}{ll}19 & (29.7) \\
45 & (70.3)\end{array}$ & $\frac{\downarrow}{\uparrow}$ \\
\hline 言 & $93(100.0)$ & $\begin{array}{ll}34 & (37.0) \\
59 & (63.0)\end{array}$ & $\frac{\downarrow}{\uparrow}$ \\
\hline
\end{tabular}

表了血色来推多a棁式

。改善型 啡改善型 喓仕型里 4名

(注) 46 年を|つのポイントとに、 43 年

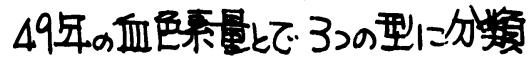
改善型・酒色素が12.0\%比上

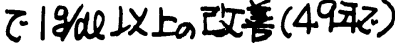

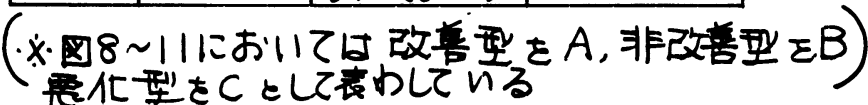

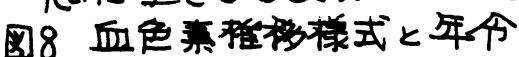

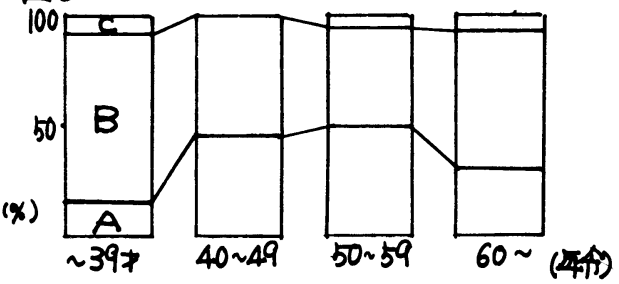

园10血色素推移碌式上收入

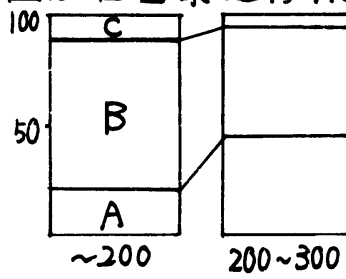

四9血色素推移美式と耕作反别

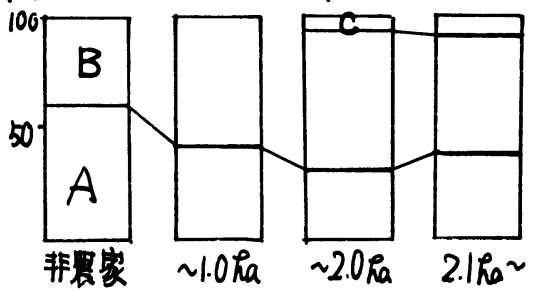

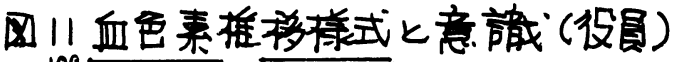

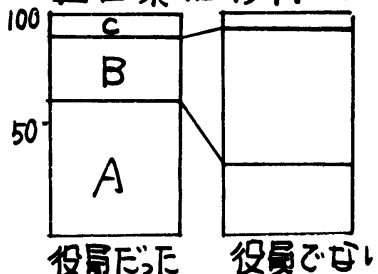

役只…地区、描等 的立場に极。

以上のデーター（一部秪面の都合上除く）及び47年来行むか水て来た

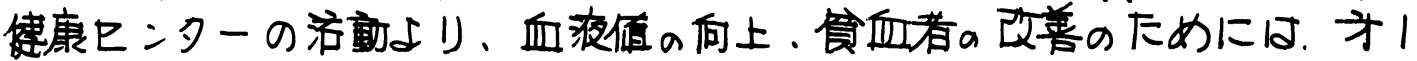

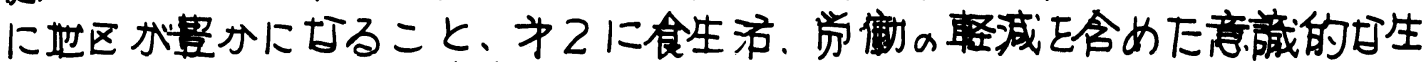

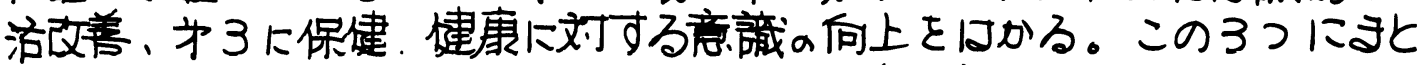
まるさうである。尚、社会調査は東洋太学社会学部の協刀にさる。 


\section{1. 農村婦人の貧血に関する研究、とくに栄養摂取と農業 形態ならびに、改善施策の効果について}

○坂東玲芳 村田 孝 久保 博 居村 剛 （徳島県厚生農協連 麻植協同病院）

はじめにこの研究の目的は, 農村婦人の貧血の実態を, 農業形態, 栄養, 季節変動の面等よ り総合的に捉えて，実態に即した改善策を講ずることにある。昨年，私達は，本学会において， 農村婦人の夏季貧血が, 病院勤務者より強く表われること, 貧血と血清鉄値の相関係数は, 病院 勤務者では 0.57 と高く, 農村婦人では 0.19 と低いこと, 農業形態の差により, 貧血の程度に 差がみられること等より, 農村婦人の貧血発現の原因として, 農業労働の影響を重視すべきであ ることを強調した。

今回は, 昨年の貧血調査と同時に施行した栄養調査の結果を検討するとともに，もっとも貧血 の強かったハウス農家婦人の貧血に対する改善施策の効果について報告する。

対象と方法 調査対象農婦人は, 全て昨年の人々である。改善施策検討の対象ハウス農家は, 表 2 に示した大型ハウス団地で, この団地に対する農業改良普及所の指導事業に，医学面より私 達が協力したものである。栄養調査の方法は，国民栄養調査に準じ，貧血検査は，昨年報告の方 法である。

結果と考察、表 1 に専業農家形態別の血色素量と, 栄養摂取状況とを対比して示した。結果を 概観すると, 多くの報告と同様な農家の特徵がみられ, 熱量はほぼ十分ながら, ミネラル，ビタ ミン等に規準量に達しないものが多く，ことに Ca , Fe において不足が目立っている。貧血群， 非貧血群，そして対照群との間には，ものにより若干の差がみられるが，血色素量の差に匹適す るほどではない。酪農農家群は，栄養摂取面では，もっともすぐれていると考えられるが，貧血 群に属し, 休養面, 労働のあり方に問題があるものと言えよう。そこで, 私達は, 団地であるた

表 1 農業形熊別にみた農家婦人の血色素量と栄養摂取状況（ 49 年7月）およびハウス農 家 昨年と今年の対比

\begin{tabular}{|c|c|c|c|c|c|c|c|c|c|c|c|}
\hline & 業 形 態 & $\begin{array}{c}\text { 血色素量 } \\
\mathrm{g} / \mathrm{dl}\end{array}$ & $\begin{array}{c}\text { 熱量 } \\
\mathrm{cal}\end{array}$ & $\begin{array}{c}\text { 蛋白質 (動蛋) } \\
\mathrm{g}\end{array}$ & $\begin{array}{c}\text { 脂肪 } \\
\mathrm{g}\end{array}$ & $\begin{array}{l}\mathrm{ca} \\
\mathrm{mg}\end{array}$ & $\begin{array}{l}\text { 鉄 } \\
\mathrm{mg}\end{array}$ & $\begin{array}{l}\mathrm{VA} \\
1 \mu\end{array}$ & $\begin{array}{c}\mathrm{VB}_{\mathrm{i}} \\
\mathrm{mg}\end{array}$ & $\begin{array}{c}\mathrm{VB}_{2} \\
\mathrm{mg}\end{array}$ & $\begin{array}{r}\mathrm{VC} \\
\mathrm{mg}\end{array}$ \\
\hline \multirow{7}{*}{ 貧血群 } & 病院看護婦 & 12.2 & 1724 & $64.2(28.4)$ & 38.0 & 423 & 12.0 & 1024 & 0.94 & 0.99 & 81 \\
\hline & つけもの & 13.1 & 2087 & $60.9(20.5)$ & 36.3 & 403 & 10.5 & 890 & 0.70 & 0.63 & 70 \\
\hline & 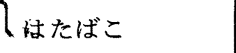 & 12.7 & 2066 & $59.6(22.2)$ & 33.7 & 396 & 10.1 & 818 & 0.77 & 0.61 & 62 \\
\hline & 蔬 菜 & 11.9 & 1952 & $=59.0(23.9)$ & 33.9 & 405 & 10.4 & 966 & 0.77 & 0.71 & 79 \\
\hline & 酪 農 & 11.7 & 2185 & $68.4(29.4)$ & 41.4 & 545 & 11.3 & 1138 & 0.80 & 0.86 & 70 \\
\hline & ハウス 49 年7月 & 10.8 & 2015 & $58.0(23.2)$ & 36.3 & 448 & 9.5 & 1208 & 0.79 & 0.75 & 89 \\
\hline & 50 年7月 & 12.9 & 1985 & $63.8(20.0)$ & 29.8 & 406 & 100 & 934 & 0.88 & 0.88 & 107 \\
\hline
\end{tabular}


め協力, 指導が比較 的容易であり, 貧血 がもっとも高度であ ったハウス農家を対 象として改善策とと りくんだのである。 その方法は, 表 3 に示したようなもの である。栄養面での 結果は, 表 1 の下段 の如きもので, この 面では,さしたる改 善はみとめられない。 血液面での効果をみ ると, 表 4 の如く,

8,9 月には若干の 貧血を示すが， 49 年 7 月ほどではなく かなりの改善と考え られる。

表 2 徳島県土成町中央温室園芸組合の経営状況

\begin{tabular}{|c|c|c|c|c|}
\hline 農家数 & $\begin{array}{c}\text { 団地のハウス } \\
\text { 平均経営面積 }\end{array}$ & $\begin{array}{c}\text { 団地以外の } \\
\text { 平均経営面積 }\end{array}$ & 家族数 & 農業従事者数 \\
\hline 10 & $26 \mathrm{a}$ & $127 \mathrm{a}(80 \mathrm{a} \sim 200 \mathrm{a})$ & $5 \cdot 7$ & $3 \cdot 2$ \\
\hline
\end{tabular}

表 3 貧血改善, 健康管理のための諸々の施策
A 栄養面について: 栄養調查, 指導. 料理講習会. 共同購入, 冷 蔵庫利用. 牛乳飲用推進. 献立表配布など。
B 労働と環境面について：労働実態調査. 気温. 湿度調査, 家族 別労働配分の工夫．休養時間の確保ととり方の工夫. 睡眠時 間確保, 休養室の作製など。
C 健康管理面について：健康診断, 疲労, 農夫症調査, 農民体操 の実施、体力テスト、講習会など。
D 全般的な意見の交換, 反省会など。

表 4 大型ハウス農家農民の 1 年余の血液性状の推移

\begin{tabular}{|c|c|c|c|c|c|c|c|c|c|}
\hline & 人数 & 年令 & & 4 9年7月 & 50年2月 & 6月 & 7月 & 8月 & 9月 \\
\hline \multirow{4}{*}{ 子 } & & \multirow{4}{*}{3} & 量 $\varepsilon$ & 08 & $152 \pm 10$ & $149 \pm 1.1$ & $150 \pm 10$ & $14.1 \pm 1.1$ & $15.1 \pm 17$ \\
\hline & & & 赤血球数 万侐 & $433 \pm 380$ & $9 \pm 344$ & $464 \pm 228$ & $464 \pm 32.1$ & $435 \pm 348$ & $439 \pm 423$ \\
\hline & & & 血清鉄 $r / d 1$. & $114 \pm 427$ & $=346$ & \pm 318 & 18.4 & $116 \pm 48.1$ & $107 \pm 233$ \\
\hline & & & 血清蛋白量 \% & $6.7 \pm 0.4$ & $73 \pm 08$ & $67 \pm 05$ & - & - & $69 \pm 0.67$ \\
\hline & \multirow{4}{*}{10} & \multirow{4}{*}{3} & 血色素量 $\mathrm{g} / \mathrm{d} 1$ & $10.9 \pm 1.1$ & $130 \pm 15$ & $123 \pm 14$ & $129 \pm 1.1$ & $115 \pm 12$ & $118 \pm 13$ \\
\hline & & & 赤血球数 万/皿 & $382 \pm 304$ & $412 \pm 323$ & $7 \pm 335$ & $400 \pm 287$ & $381 \pm 345$ & $382 \pm 37$ \\
\hline & & & 血清鉄 $\quad r / d 1$ & $82 \pm 223$ & $108 \pm 37.1$ & $2 \pm 277$ & 17.2 & $95 \pm 20.3$ & $97 \pm 20.1$ \\
\hline & & & 血清蛋白量％ & $6.9 \pm 0.4$ & $7.6 \pm 0.6$ & $7.2 \pm 0.5$ & - & - & $73 \pm 02$ \\
\hline
\end{tabular}

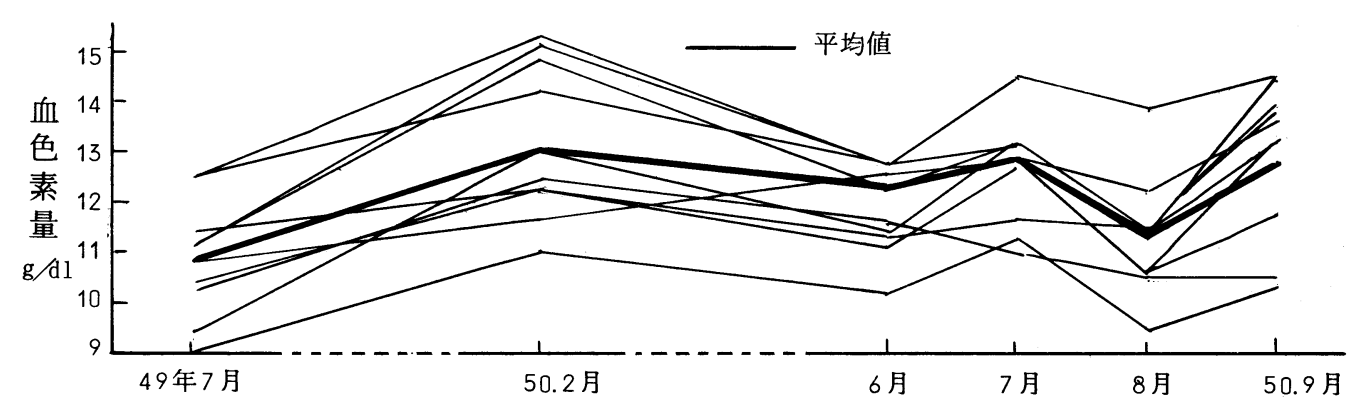

四 1 八ウス農家婦人の血色素量の個人変動 $(49,7 \sim 50,9)$

上記の諸施策, ことに休養面での工夫が効果を示したものと考えたい。図 1 には個人別の变動 を示したが, 血色素量低值の人は, 年間を通じて低い傾向にあり, 個人別の指導の必要が考えら れる。なおこの調査, 指導で痛感せられることは, 健康に関する意識の昂揚の重要性と, 栄養面 では一家をあげてのこれに対する知識の向上の必要性である。

おわりに 責血の有無は, 健康の指標と言うべく,その意味で, 負血の改善運動には, 栄養面は 勿論, 農業労働, 農家生活そのものの改善が重要であり, この一例を農業形態と栄養摂取, 八ウ ス農家の改善運動の面より報告した。 


\title{
222. 愛知県海部地区に於ける貧血実態調查（第 2 報）
}

\author{
荒川忠男荒木紹一 \\ 戸谷久美子井上一夫
}

(愛知県厚生連海南病院)

前回，鍋田干拓地区の総合保健調查の一環として貧血の実態調查を行い， 本学会にて報告したが, 今回は海部地区で輪中を形成する立田村の貧血実 態調查を農山漁家家族労働適性化特別事業の中で 49 年よりとりあげたので, その内容を第 2 報として報告する。調查方法は，鍋田干拓と同じく早朝空 腹時に行った。部落構成は, 米作農家, 酪農家, 温室栽培と多種で立田村 小茂井地区は戸数にして 65 世帯である。

\section{成績及び結語}

1) 図 1 は, 前回の対象地区であった鍋田干拓と立田村の比較 $\mathrm{H} \mathrm{b}$ 異常出 現率であり，男子の 49 年度では全体で $25.4 \%$ の高率をしめて特に，40才代 が高く同年代別でみると 40 才代より 39 才以下が $36.4 \%$ の高值を示した。 50 年度では全体で $11.1 \%$ と前年に較べ $56.3 \%$ の大巾減少であった。女子では 全体で，50.9\%の高率であり，40才代に多く同年代で $61.3 \%$ 異常群を見 いだした。50年では全体で $35.6 \%$ で前年に較べ $30.1 \%$ の減少で 40 才台でも $24.4 \%$ の出現率であったが, 同年代をとってみても $45.8 \%$ と約半数に近い 出現率で全体では40才代が男女共高い出現率をしめした。

2) $\mathrm{H} \mathrm{b.} \mathrm{H} \mathrm{t}$ の 49 年, 50 年度の平均值を表わしたものが, 図 2 であり 49 年 より 50 年度の方が高值, 即ち正常レベルにより近くなってきたことがわか る。

3） $\mathrm{Hb}$ の異常出現頻度別に表わしたのが図 3 であり，49年度では男子に $12.9 \mathrm{~g} / \mathrm{d} 1$ 以下の人が $25.4 \%$ あり, $11.9 \mathrm{~g} / \mathrm{d} 1$ 以下の人が $9.1 \%$ めむた。 女子では, $11.9 \mathrm{~g} / \mathrm{d} 1$ 以下に $26.3 \%, 10.9 \mathrm{~g} / \mathrm{d} 1$ 以下に $24.5 \%$ 高率をしめし た。 50 年度では, 男子で $12.9 \mathrm{~g} / \mathrm{d} 1$ 以下は $11.1 \%$ 前年に較べ著明に減少し $11.9 \mathrm{~g} / \mathrm{d} 1$ 以下は 0 でした。女子でも $11.9 \mathrm{~g} / \mathrm{d} 1$ 以下が $22.2 \%, 10.9 \mathrm{~g} / \mathrm{d} 1$ 以下 が $13.3 \%$ と減少した。

4) 表 1 は, $\mathrm{Hb}, \mathrm{Ht}$ 等を平均值 $\pm \mathrm{SD}$ で表わしたものですが, 男子の $\mathrm{Hb}$ では平均值が前年度より $0.7 \mathrm{~g} / \mathrm{dl}, \%$ で，\%にして $(11.4 \%)$ と上昇した。女子でも $\mathrm{Hb}$ $\%) ， \mathrm{Ht}$ t $4.2 \mathrm{~g} / \mathrm{d} 1 ％$ にして $(12.9 \%)$ それぞれ上昇した。

結語以上の様に 2 年次目は初年度と比較した場合，かなり良くなってい た。その原因として，(1) 部落全体の健診に対する心がまえ。(2)健康保持の 為の啓蒙運動。(3)データー還元による説明会及び講演。(4)料理構習等を行 った。以上の様に部落全体として此の事業に取り組んだ住民の力を評価し なければならないが, しかし他地域と比較した場合, 尚, 高異常出現率は 
高く，特に40才代において高值を示した。この原因については不明の点が 多く, 今後の課題としたい。

表 1 年度別対比表

\begin{tabular}{|c|c|c|c|c|c|c|c|}
\hline 性別 & 年 度 & $\mathrm{H} \mathrm{b}$ & $\mathrm{H} \mathrm{t}$ & R B C & $\mathrm{MC} \mathrm{V}$ & C I & $\mathrm{S}-\mathrm{Fe}$ \\
\hline \multirow{4}{*}{$\hat{\delta}$} & 49年度 & $13.4 \pm 1.1$ & $34.3 \pm 2.6$ & $397 \pm 31$ & $98.7 \pm 4.9$ & $1.05 \pm 0.07$ & $107 \pm 45$ \\
\hline & 50 年度 & $14.1 \pm 0.9$ & $39.1 \pm 4.2$ & $425 \pm 37$ & $91.9 \pm 5.9$ & $1.04 \pm 0.07$ & $127 \pm 49$ \\
\hline & 年度差 & 0.7 & 4.8 & 28 & 6.9 & 0.01 & 20 \\
\hline & 增減率 & $5 \%$ & $11.4 \%$ & $7 \%$ & $\triangle 7 \%$ & $0 \%$ & $19 \%$ \\
\hline \multirow{4}{*}{ 우 } & 49年度 & $11.7 \pm 1.3$ & $32.7 \pm 7.0$ & $369 \pm 32$ & $97.0 \pm 6.2$ & $0.99 \pm 0.12$ & $98 \pm 55$ \\
\hline & 50年度 & $12.7 \pm 1.1$ & $36.9 \pm 3.7$ & $397 \pm 29$ & $93.2 \pm 6.6$ & $0.96 \pm 0.08$ & $108 \pm 40$ \\
\hline & 年度差 & 1.0 & 4.2 & 28 & 3.8 & 0.03 & 10 \\
\hline & 増減率 & $8.5 \%$ & $12.9 \%$ & $7.6 \%$ & $\triangle_{3.9 \%}$ & ${ }^{\Delta} 0.3 \%$ & $10.2 \%$ \\
\hline
\end{tabular}

図 1

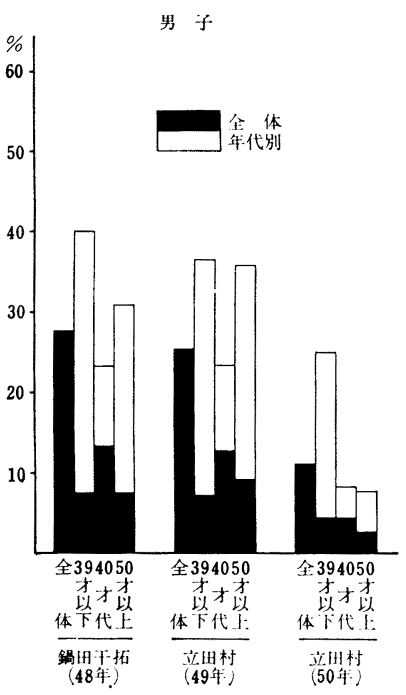

$\mathrm{Hb}$ 異常出現率

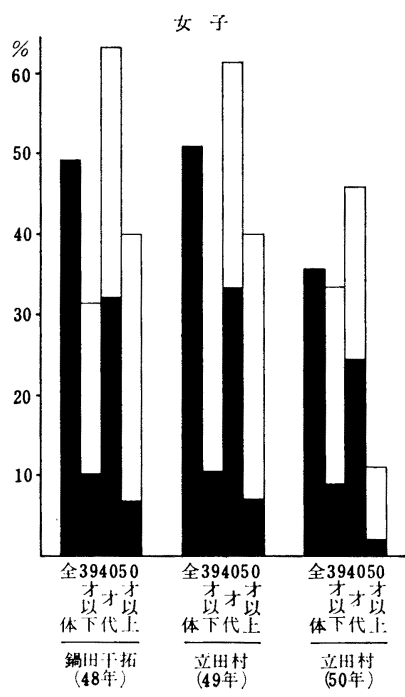

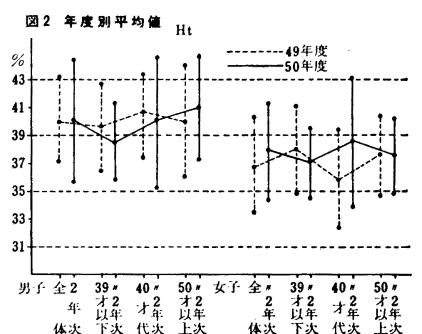

$\mathrm{Hb}$

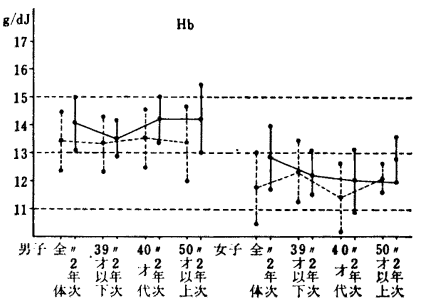

$3 \mathrm{Hb}$ 具需出理 $8 / \mathrm{dL}$

49年度
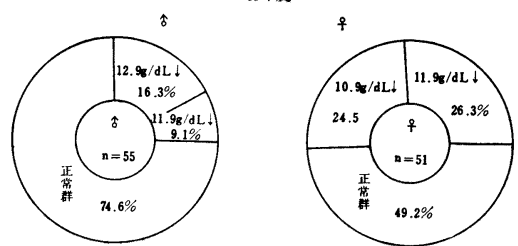

50 年度
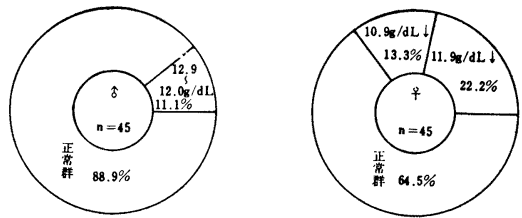


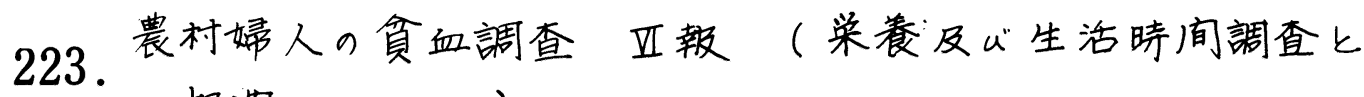

の相闺以ついマ)

\section{O小川美替子(现珂保健所)}

䃇田紀孝長尾康子(宇部短期大)

農村媂人の頜血の成因及心゙实態の把握と对策の樹立を目的として更下

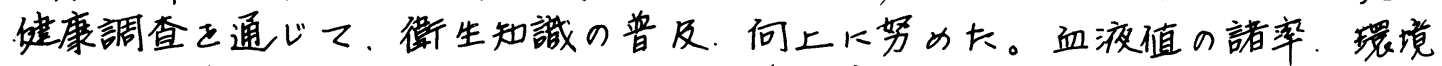

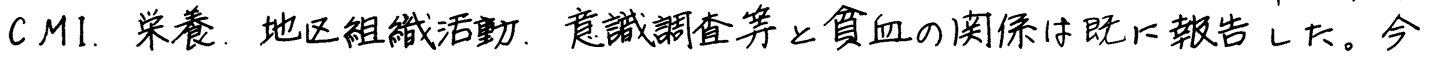

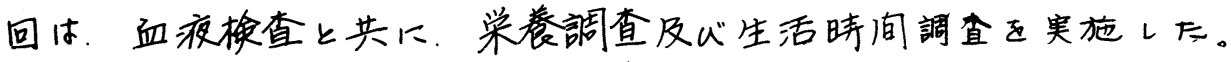

I 調查方法: 山口県東部の震村の20才以上の男子60名、女子《名卜つ いて突施し下。調查時期は49年8月である。血疾検查の一部以ついては。

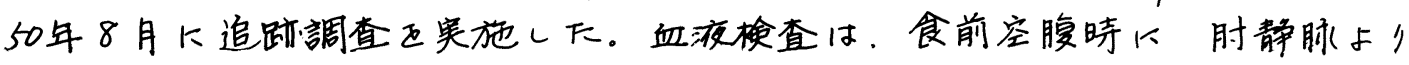
採血し下。赤血球( RBC) は自動血球計算器を便用し。血色素( Hb)は洱汹卜

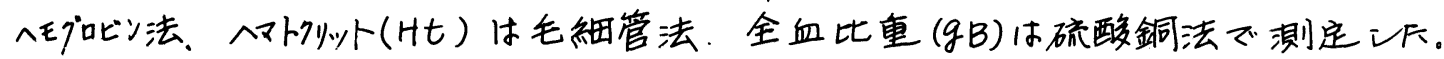

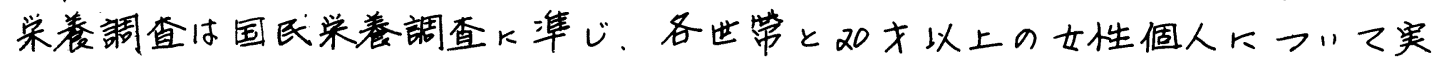

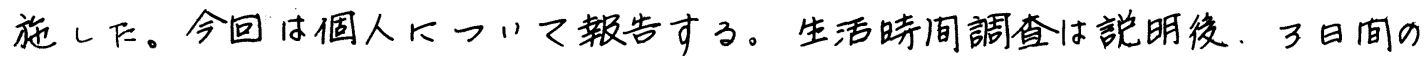

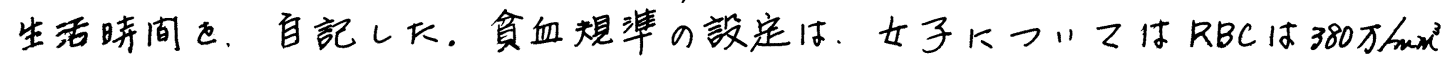
Hbは. $12 \%$ / d . Htは $36 \%$ 。 gBは1.052の各值の未渵とし下。

II調查成绩：1）性别。血疫性状别平均值及心゙標準偏差は。表正下 示レ下。H有的は有意差が認力ら水大。女子の工回正回の成績也比較し

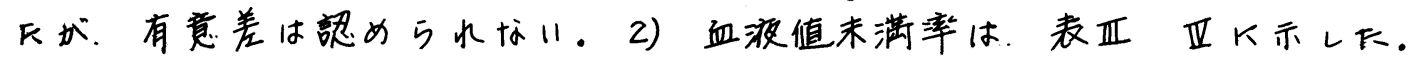

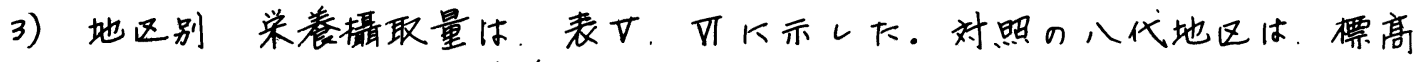

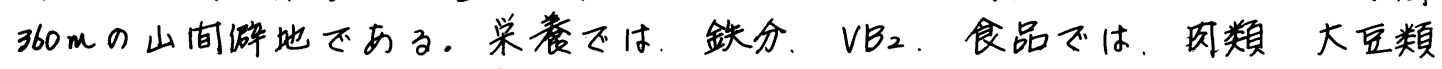

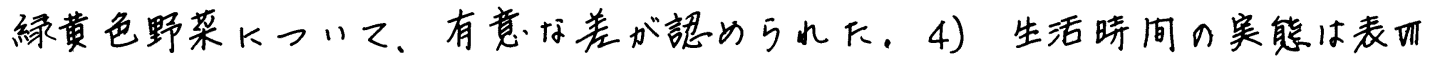

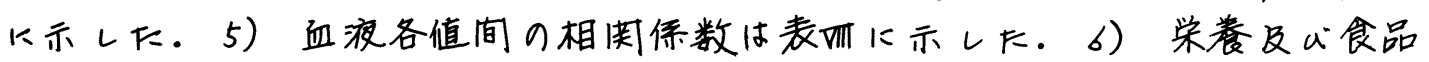

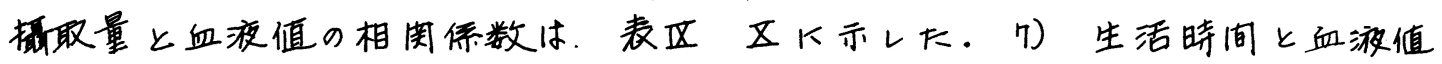

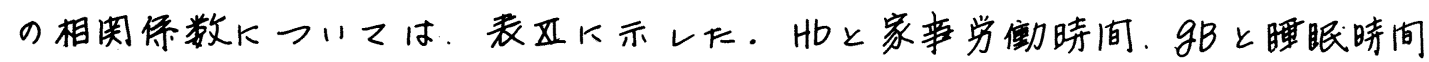

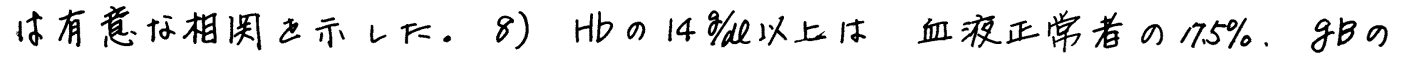

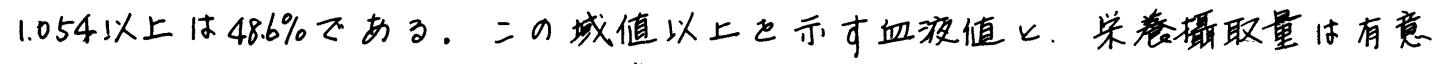

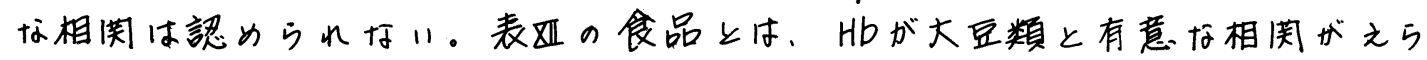

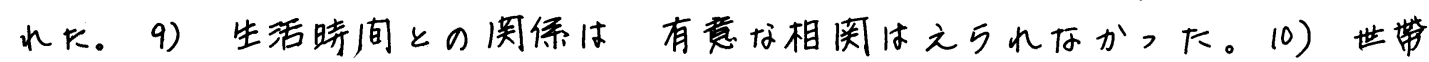

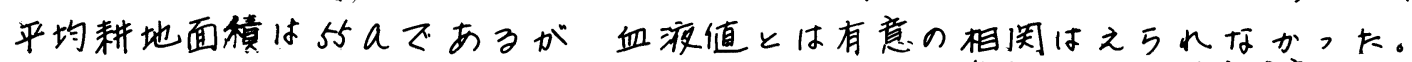

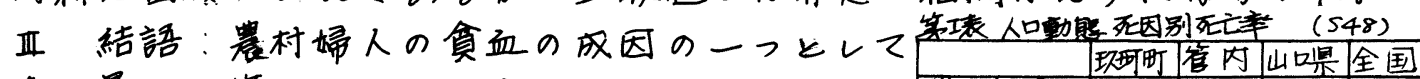
染秦の量及心算の欠陌を指绱して113。血液值と

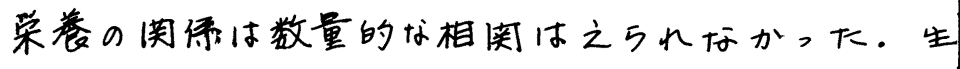
活時间上血液值の一部は，数量的标相闺优認的

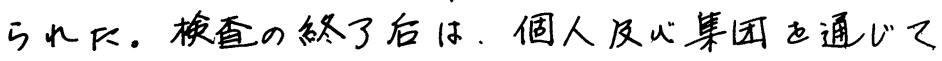
建康ブくりの推進下努め下。

\begin{tabular}{|c|c|c|c|c|}
\hline 里 & & & & \\
\hline$\frac{4 \pm 1}{5}$ & 17.0 & 15. & 17. & \\
\hline $\mid$ & 9.4 & 9.5 & 8. & \\
\hline 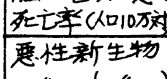 & 81.6 & 279. & 208. & \\
\hline 心疾急北方 & 13.4 & 142. & 146 & \\
\hline
\end{tabular}




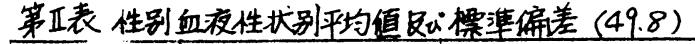

\begin{tabular}{|c|c|c|c|c|}
\hline & \multicolumn{2}{|c|}{ 男 (60名) } & \multicolumn{2}{|c|}{ 女(111名) } \\
\hline & 平均值 & 镍偏差 & 平均值 & 酳偏差 \\
\hline 赤血球甭 & 405.69 & 62.20 & 391.85 & 41.03 \\
\hline 血色意 $\mathrm{g} / \mathrm{dl}$ & 15.12 & 1.78 & 13.33 & 1.69 \\
\hline$\Delta$ 가네나 & 42.07 & 3.68 & 38.33 & 3.66 \\
\hline 全血比重 & 1.0550 & 0.003 & 1.0529 & 0.003 \\
\hline 血清蛋白 $\mathrm{g} / \mathrm{dl}$ & 7.28 & 0.46 & 7.45 & 0.56 \\
\hline 血清鉄 ${ }^{m g} / d e$ & 95.69 & 23.68 & 84.00 & 37.33 \\
\hline 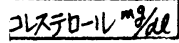 & 135.83 & 19.26 & 146.36 & 30.65 \\
\hline
\end{tabular}

第武地区别策食攝取量（女）

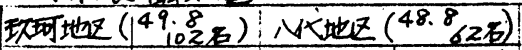
平均値標萃偏差平均侹標藮偏差

\begin{tabular}{|c|c|c|c|c|}
\hline 蛋白算(g) & 51.41 & 13.82 & 54.28 & 16.76 \\
\hline 分 $(\mathrm{mg})$ & 11.09 & 4.21 & 9.73 & 3.46 \\
\hline $1.82(\mathrm{mg})$ & 0.78 & 0.40 & 0.58 & 0.20 \\
\hline
\end{tabular}

第正表生活時间調查平均值（女）

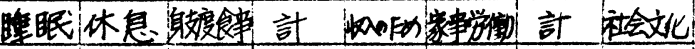

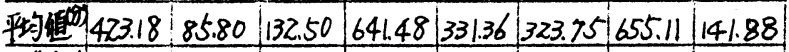
\begin{tabular}{|l|l|l|l|l|l|l|l|l|}
\hline & 36.97 \\
\hline
\end{tabular}

\begin{tabular}{|c|c|c|c|}
\hline 第正表 & 别血渡 & 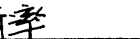 & $(49: 8)$ \\
\hline & 害 & 4 & $x^{2}$ \\
\hline 赤血球 & $26.7 \%$ & $36.0 \%$ & 1.16 \\
\hline 血色素 & 20.0 & 12.6 & 1.13 \\
\hline ヘマト7リット & 30.0 & 20.7 & 0.14 \\
\hline 全血比重 & 45.0 & 33.3 & 1.79 \\
\hline
\end{tabular}

\begin{tabular}{|c|c|c|c|}
\hline & 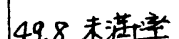 & 1508 未满主 & \\
\hline 赤血球 & 36.0 & 39.39 & 0.08 \\
\hline 血色委 & 12.6 & 21.21 & 1.70 \\
\hline ヘマトフリット & 20.7 & 15.15 & 1.25 \\
\hline 全血比重 & 33.3 & 19.70 & $\times 4.50$ \\
\hline
\end{tabular}

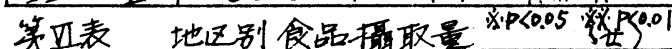

\begin{tabular}{|c|c|c|c|c|}
\hline & \multicolumn{2}{|c|}{ 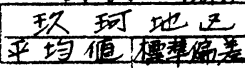 } & \multicolumn{2}{|c|}{ 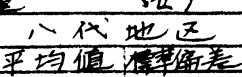 } \\
\hline 夏 $(g)$ & 55.88 & & 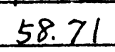 & \\
\hline$=$ & & & 4. & \\
\hline 54 & 42. & & & \\
\hline 乳㓶品(趹) & 82 & & & \\
\hline & & & & 44. \\
\hline 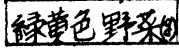 & & & 36.5 & $42.3=$ \\
\hline
\end{tabular}

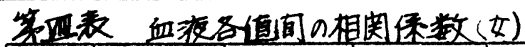

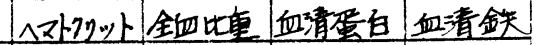

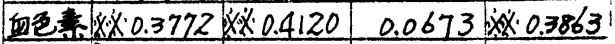

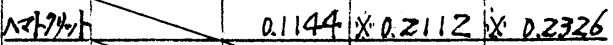
铎地里 $\quad 0.0565 \times 0.2286$

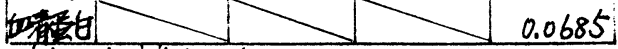
$x<0<0.05 \times x<0.01$

等又表食品群上血源值a相园保教（世）

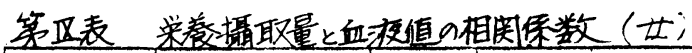
血色素、汁7归全血比重血清蛋白血清金失 \begin{tabular}{|l|l|l|l|l|l|}
\hline 蛋自鿓 & 0.0152 & 0.1750 & -0.1856 & 0.0025 & -0.0334 \\
\hline
\end{tabular}

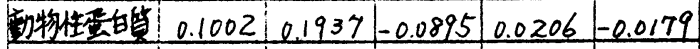
\begin{tabular}{ll|l|l|l|l|l|}
\hline 鉄 分 & 0.1083 & 0.1645 & -0.0729 & 0.0073 & 0.0656 \\
\hline
\end{tabular} \begin{tabular}{l|l|l|l|l|l|l|} 
v. BZ & 0.1163 & 0.1629 & -0.0219 & 0.1121 & 0.1207 \\
\hline
\end{tabular}

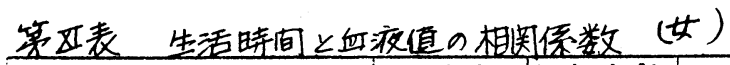

\begin{tabular}{|c|c|c|c|}
\hline & 血色素 & 全血比重 & 血清釷 \\
\hline 重介類 & 0.0935 & -0.1117 & -0.1757 \\
\hline 肉類 & 0.0314 & -0.0246 & 0.0838 \\
\hline 皿 & 0.0833 & -0.0618 & 0.1207 \\
\hline 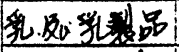 & 0.0077 & -0.0526 & 0.0696 \\
\hline 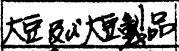 & 0.1618 & 0.1778 & -0.0019 \\
\hline 逐萑色野菜 & 0.0182 & -0.0111 & -0.1161 \\
\hline
\end{tabular}

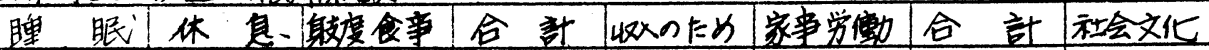
\begin{tabular}{l|l|l|l|l|l|l|l|l|}
\hline 血色素 & 0.0373 & -0.0017 & -0.0518 & 0.0028 & 0.0870 & $\times 0.3292$ & -0.0881 & 0.2565 \\
\hline
\end{tabular}

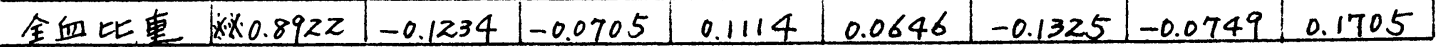
$P<0.01$

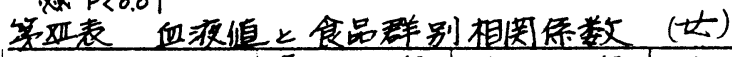

\begin{tabular}{|c|c|c|c|c|c|c|}
\hline & 重介類 & 類 & 㯰 & 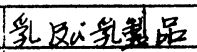 & 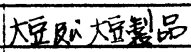 & 粶英色野菜 \\
\hline 色素 & -0.2738 & -0.1594 & 0.0615 & -0.0770 & $\dot{x} 0.4845$ & 14 \\
\hline 血比重 1.054 ! 2 上(36) & -0.2739 & -0.1227 & -0.1175 & -0.0404 & -0.0395 & 0.1410 \\
\hline
\end{tabular}
$x \cdot p<0.05$

第而表血疫值と生活時闻别相园保数（世）

\begin{tabular}{|c|c|c|c|c|c|c|}
\hline & 腄 & 休 & 身支度食事 & H又XのEめ & 家事労働 & 社会文化 \\
\hline 血色䇣 $14 \%$ \% 次(17人) & -0.2926 & -0.0439 & 0.4216 & -0.3924 & -0.3629 & -0.1335 \\
\hline 锰比重10541x上(36人) & 0.0609 & -0.2533 & -0.0119 & 0.0511 & 0.0116 & 0.0324 \\
\hline
\end{tabular}


224. 佐唭県における農村婦人の圓血につりて。

津田宏( 作贺景社会保俟作乫病院)

\section{(はじめに)}

传贺具にお、ては昭和35年度上り佐賀具共济速の主催で蕽村巡回健康租 談を实施し昭和41年度からは一家の中心となつて仂く帪村媂人を対象とし た震村媂人健康相談に切换えて現在も続けて居了加昭和45年度以降の分で 貪血の推移につりて統計的钼察を試子ることとする。

(娭查方法)

肘静脉血採血により毛細管法によるへマトワリツ下檤の测定を行なつて 35\%を貪血疑りとし $34 \%$ 以下を莫血として集計した。

( 成績)

\begin{tabular}{|c|c|c|c|c|c|c|}
\hline 年度 & 实施時期 & 組合数 & 受診者数 & 食血疑(114 35\%) & 食血 (Ht 34\%以下) & 合計 \\
\hline & 7 月 9月 & 21 組合 & 1980 名 & 213 名 $(10.8 \%)$ & 389 名(19.7\% & 602 名 $(30.4 \%)$ \\
\hline & 7月一 -9月 & 19 & 1950 & $194 "(10,0 \%)$ & $367=(18.8 \%)$ & $561 "(28.8 \%)$ \\
\hline 47 & 丁月 $~ 2$ 月 & 18 & 1675 & $211 "(12,6 \%)$ & $384 "(22,9 \%)$ & $595 \cdot(35.5 \%)$ \\
\hline & 7月一 9月 & 25 & 3068 & $395 "(12.9 \%)$ & $\mid 468 \%(15,3 \%)$ & $863=(28.1 \%)$ \\
\hline 49 & 7 月 $~ 1$ 月 & 34 & 3916 & $327=(8.4 \%)$ & $596=(15.2 \%$ & $923=(23.6 \%)$ \\
\hline 合 & & $1 / 7$ & $12589=$ & $1340:(10.6$ & $2204:(17.5 \%$ & $3544 "(28.1 \%)$ \\
\hline
\end{tabular}

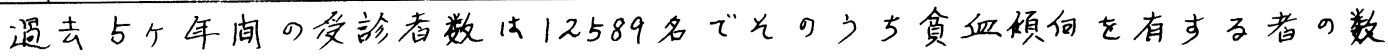
は3544名で28.1\%に達した。年度别で47年度を除いて年々好転している。

\begin{tabular}{|c|c|c|c|c|c|c|c|c|c|c|}
\hline 表 2 & $\sim 29 才$ & $-39 \pm$ & $\sim 49 \pm$ & $\sim 59$ 戈 & 60 戈〜 & $\sim 29 x$ & $\sim 39$ 戈 & $\sim 49 x$ & $\sim 59$ 戈 & $60 \mathbb{1} \sim$ \\
\hline 45年度 & $30.6 \%$ & $20.3 \%$ & $19.7 \%$ & $16.4 \%$ & $11.8 \%$ & $13.5 \%$ & $10.8 \%$ & $10.0 \%$ & $10,5 \%$ & $15,8 \%$ \\
\hline 46 & $24.1 \%$ & $19.7 \%$ & $19.8 \%$ & $13.6 \%$ & $19.4 \%$ & $12,7 \%$ & $10.3 \%$ & $9.5 \%$ & $9.9 \%$ & $9.7 \%$ \\
\hline 47 & $24.5 \%$ & $21.8 \%$ & $24.1 \%$ & $22,7 \%$ & $19.7 \%$ & $10.2 \%$ & $13.9 \%$ & $11.5 \%$ & $13.9 \%$ & $11.8 \%$ \\
\hline 48 & $12.1 \%$ & $17,4 \%$ & $15.7 \%$ & $12.9 \%$ & $13.4 \%$ & $15,8 \%$ & $13.4 \%$ & $12.0 \%$ & $14.2 \%$ & $8,5 \%$ \\
\hline 49 & $17.8 \%$ & $15.6 \%$ & $16.4 \%$ & $13.5 \%$ & $10.9 \%$ & $9.5 \%$ & $7.8 \%$ & $8,3 \%$ & $8.8 \%$ & $7.8 \%$ \\
\hline 計 & $19.5 \%$ & $18,3 \%$ & $18.5 \%$ & $15.0 \%$ & $14,1 \%$ & $12.3 \%$ & $10,9 \%$ & $10.2 \%$ & $11.1 \%$ & $9,9 \%$ \\
\hline & \multicolumn{5}{|c|}{ 貟血 (Ht 34\% bर下) } & \multicolumn{5}{|c|}{ 貪血疑”( H $35 \%$ ) } \\
\hline & $\sim 29 x$ & $\sim 39$ 戈 & $\sim 49 \pm$ & $\sim 59 x$ & 60才⿺辶 & & & & & \\
\hline 綘計 & $31.8 \%$ & $29.2 \%$ & $28.6 \%$ & $26,0 \%$ & $24.0 \%$ & & & & & \\
\hline
\end{tabular}

年令别に子ると若年者はど食血率が高くなつている、又40戈代までは全体

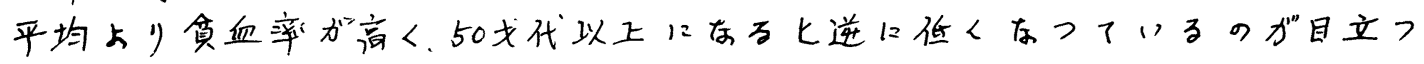
ている。 
尚へマトクリツト值を实施組合别に受診者平均值をとつて48年度と49年 度を比較して子ると48年度はへマトクリツト值36\%の地区が5瓶合37\%の 地区が14組合，38\%の地区が4組合３９％の地区が之組合わつたのに対し49年 度は36\%の地区が4組合３7\%の地区加14組合，38\%の地区加1/組合，39\%の地 区が2組合4 $40 \%$ の地区加2组合であフた。徜48年度は实施時期が7月むり 9月までであつたが、49年度は7月より翌年1月までにがけて实施したので 全体的には49年度が好転しているが49年度の7月がら9月までの分を対比 してみると48年度とは龙人ど变少が認められない。大体7月から9月まで

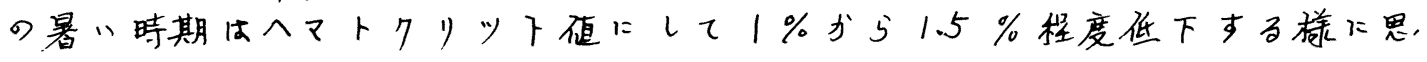
われる。

\section{(参考事项)}

1. 睡眠時间

\begin{tabular}{|c|c|c|c|c|c|c|c|c|}
\hline & \multicolumn{4}{|c|}{ 曹 繁 期 } & \multicolumn{4}{|c|}{ 農 闲 期 } \\
\hline & ～与時闲 & 6 時间 & 7 時自 & 8 時间 & $\sim 5$ 時间 & 6 時间 & 7 待间 & 8 间 \\
\hline 44 年 & $19.7 \%$ & $32.5 \%$ & $33.9 \%$ & $14.7 \%$ & $2: 3 \%$ & $13.7 \%$ & $37,2 \%$ & $46.8 \%$ \\
\hline .49年 & $9.0 \%$ & $30.1 \%$ & $40.0 \%$ & $20.9 \%$ & $2.0 \%$ & $10.9 \%$ & $37.1 \%$ & $50.0 \%$ \\
\hline
\end{tabular}

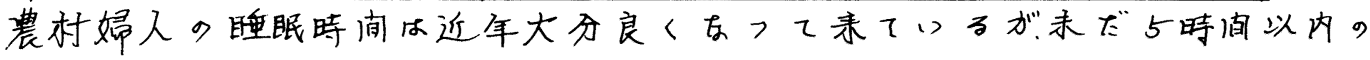
睡眠しかとない人戊居る樣である。

2 但蛋白血( $6.4 \mathrm{~g} / \mathrm{de}$ 以下)

低蛋白血者は48年度には9.2\%に認められにが49年度では6.6\%の率であつ

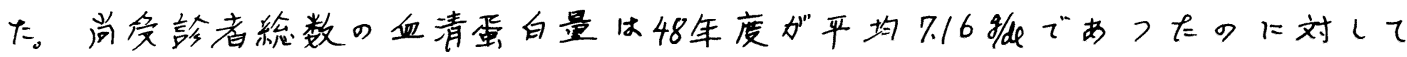
49年度は7.24 g/al 飞若干好転していた。

3. 震夫症

\begin{tabular}{|l|c|c|c|c|c|}
\hline & 45 年 & 46 年 & 47 年 & 48 年 & 49 年 \\
\hline 曹夫症 & $10.3 \%$ & $9.9 \%$ & $10.3 \%$ & $10.4 \%$ & $7.3 \%$ \\
農夫症督“ & $48.8 \%$ & $48.9 \%$ & $47.3 \%$ & $46.4 \%$ & $44.5 \%$ \\
合計 & $59.1 \%$ & $58.8 \%$ & $57.6 \%$ & $56.8 \%$ & $51.8 \%$ \\
\hline
\end{tabular}

裳夫症は年々減少刀碩向 を示して居るが未だ箼夫症 症候群の全く算〉と思われ

4. 産前座後9農作丵休止期间。

る者は遏半数に淦たない。

現在40戈以上の人が昔姓娠時期に心産前私人ど费作菜を休ま左り率が $95 \%$ 程度であつにが現在20戈代の入は74\%程度に減少して来ている。

産後においては1週间程度の休養で晨作羓吉始める人は叺代では殁人

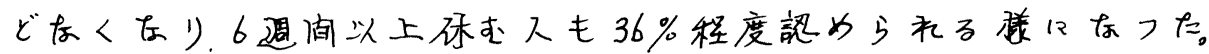

(むすで)

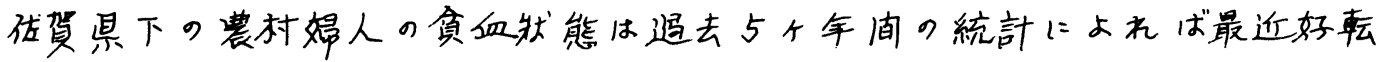

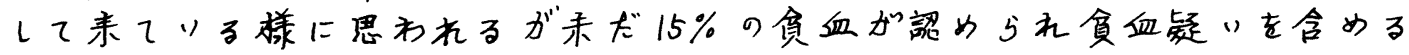
と24\%の高率となり、当累においても農村婦人に貪血加多り事を示している。 農村嫜人に盆血が多》原因につ、ては今尚判然としていはいが少なくとも 生活環境の改善によつて尚一層好転が期待される事だけは间遗いないと考 之るので生活指售員等の協力によつて向上に努めて行きたり。 


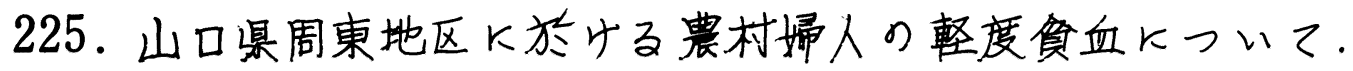

○浜田克裕，有馬和雄，三宅隆生，新福輔載， 最所陽太郎，神田悟，沃本延高

研究目的：

(山口杲, 周東铰合病䟚)

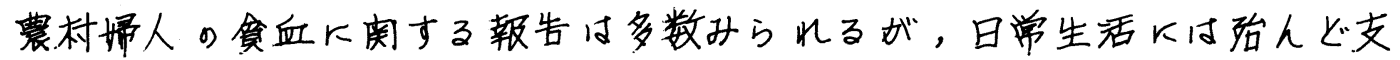
障を来与告い程度の，所謂，軽度貧血についての報告はあるりみられるい。 そ乙で我々は，厚生省委託研究の一環として，山口萛周束地区以於りる， H $10.0 \sim 11.98 / 2$ 程度の整度畕血を有する震村婦人Kついて，その原因・性 状等火ついての实態調查を試み火。

研究方法:

山口深周東地方より，日積地区(曹山村) 及代平生地区（半整半渙村）

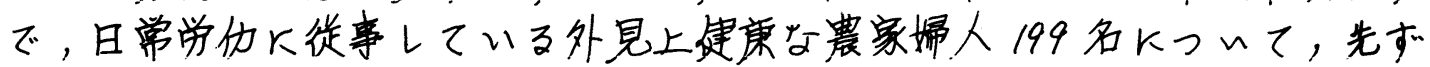

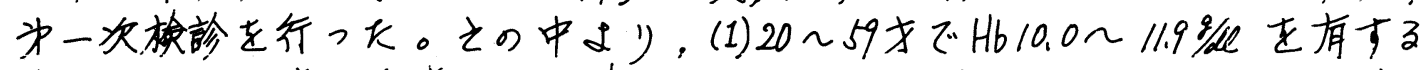

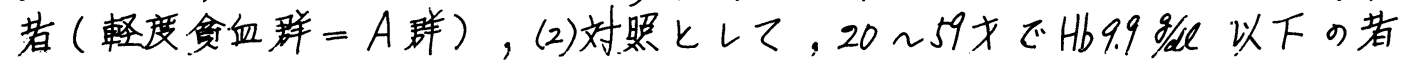

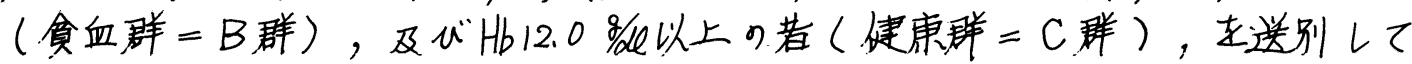
为二次検診を行をった。

研究成積:

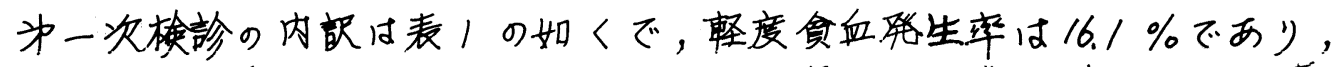
$30 \sim 40$ 才代K多的。調查地区別Kみると(表2)，震山村不ある日積地区

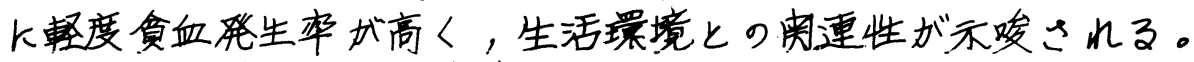

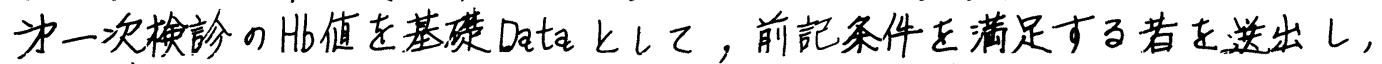

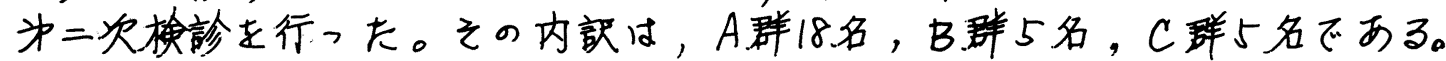

(1)年令别発生率; 表了の如くで，A群18例中11例(61.1\%) 1400代の

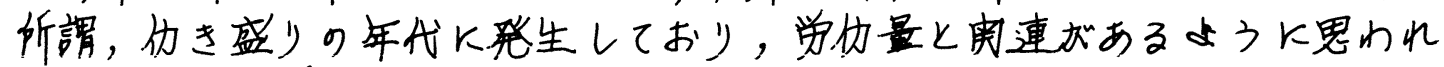
る。B群も同様である。

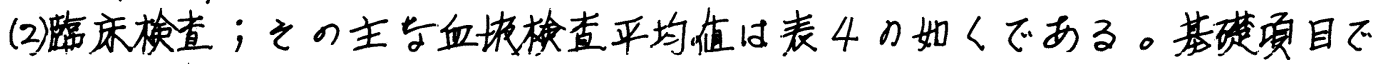

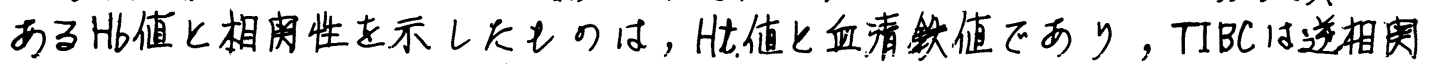

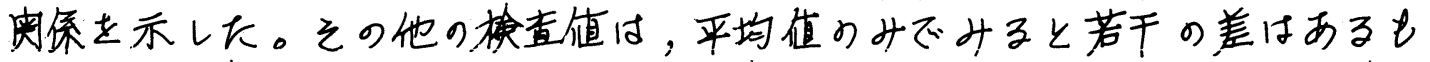
の〉，個人值のばらつき加大きく，有意差飞は判定出来与办つ下。B群付 全て铁欠乏性筫血を示しKの大対し，A群では18例中14例小铁久乏性，4

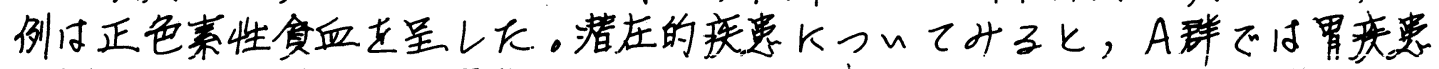

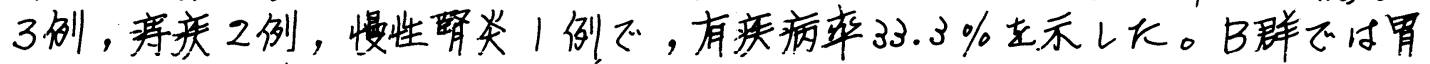

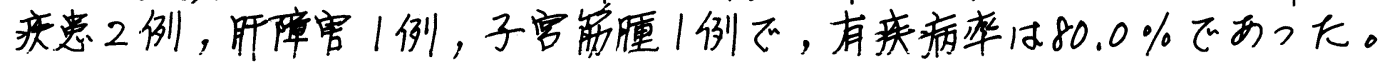
これらの疾病が，直ち飞貧血の原因である飞は断定出来をいが，外見上， 健康火みえる者火ン，がりの潜在疾患汃存在している事加判明しK。

(3)自党症状・之の他; 主与自賞症状然現率山表与の如く飞゙，易波労威， 


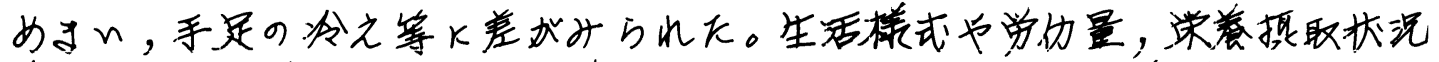

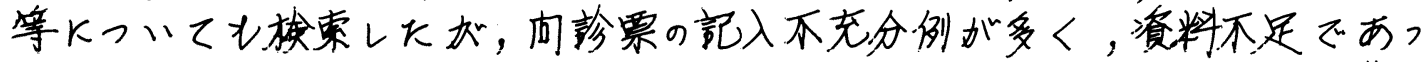

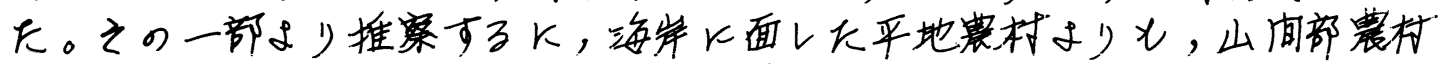

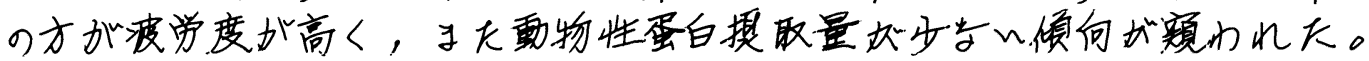

结㖮:

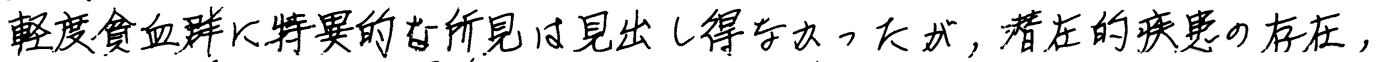

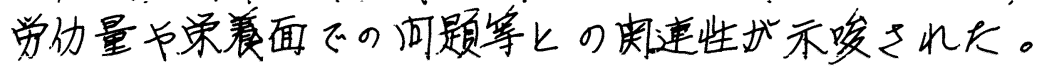

表 1: 为一次桧彭年代别 Hb.

\begin{tabular}{|c|c|c|c|c|}
\hline 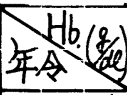 & 12.001 上 & $\begin{array}{l}10,0 \\
\sim 11,9\end{array}$ & 9.9 以下 & 計 $(\%)$ \\
\hline $20 \sim 29^{7}$ & 5 & 11 & $0^{k}$ & $6^{2}(3,0)^{\circ}$ \\
\hline $30 \sim 39$ & 23 & 10 & I & $34(1 \% .1)$ \\
\hline $40 \sim 49$ & 40 & 12 & 6 & $58(29.1)$ \\
\hline $50 \sim 59$ & 58 & 2 & 0 & $60(30.2)$ \\
\hline $60 \sim$ & 34 & 7 & 0 & $4 /(20.6)$ \\
\hline 計 $(\%)$ & $160_{(804)}^{4}$ & $32(16,1)$ & $7_{(35)}$ & $199(100.0)$ \\
\hline
\end{tabular}

表了；为二次检新年代别 H .

\begin{tabular}{|c|c|c|c|c|}
\hline 年令 & 12,0 W & $\begin{array}{l}10.0 \\
\sim 11.9\end{array}$ & 9.9 W $F$ & 計 (\%) \\
\hline $20 \sim 29^{7}$ & $0^{1}$ & $1^{\lambda}$ & $0^{x}$ & $I^{1}(3.6)$ \\
\hline $30 \sim 39$ & 2 & 4 & 0 & $6(2 / 14)$ \\
\hline $40 \sim 49$ & I & $1 /$ & 5 & $17(60,3)$ \\
\hline $50 \sim 59$ & 2 & 2 & $\overline{0}$ & $4(14.3)$ \\
\hline 計 & 5 & 18 & 5 & $28(100.0)$ \\
\hline
\end{tabular}

表5；自賞症状现率

\begin{tabular}{|c|c|c|c|}
\hline 症状臂 & A & $B$ & C \\
\hline 易疲学感 & $44,4^{\%}$ & $100.0^{\%}$ & $20.0^{40}$ \\
\hline めるレ & 38.9 & 60.0 & 20.0 \\
\hline 動悸息找水 & 33.3 & 60.0 & 40.0 \\
\hline 手足の次之 & 27.8 & 40.0 & 0 \\
\hline 喤 & 5.6 & 20.0 & 0 \\
\hline 肩沙腰痛 & 72.2 & 100.0 & 100.0 \\
\hline
\end{tabular}

表2；地区别整度食血発生率

\begin{tabular}{|c|c|c|c|}
\hline 地区 & 受钐者数 & 雱度拿 & 発生率 \\
\hline 平生地区 & $125^{\wedge}$ & $16^{\wedge}$ & $12.8^{\%}$ \\
\hline 日積地区 & $74^{\wedge}$ & $16^{\lambda}$ & $21.6^{\%}$ \\
\hline
\end{tabular}

\begin{tabular}{|c|c|c|c|}
\hline 項目群 & $A$ & $B$ & C \\
\hline$H b(\mathrm{~g} / \mathrm{de})$ & 11.2 & 9,3 & 13.9 \\
\hline Ht. $(\%)$ & 35,2 & 31.0 & 40.6 \\
\hline$R B C\left(\frac{x 10^{*}}{\text { cing }}\right.$ & 375 & 364 & 426 \\
\hline$W B C(/ \mathrm{cm}$ & 5005 & 4080 & 6380 \\
\hline 血小板 $\left(\times 10^{4}\right.$ & 20 & 25 & 29 \\
\hline 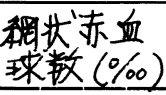 & 7.6 & 8.0 & 7.0 \\
\hline 血清鉃( & 63.1 & 25.4 & 93.2 \\
\hline TIBC & 372.4 & 449.2 & $3 / 4.8$ \\
\hline 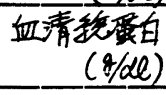 & 7.5 & 7.3 & 8.0 \\
\hline$A / G$ 比 & 1.49 & 1.29 & 1.49 \\
\hline
\end{tabular}


226. 熊本県下。会血の实態と経年的堆移

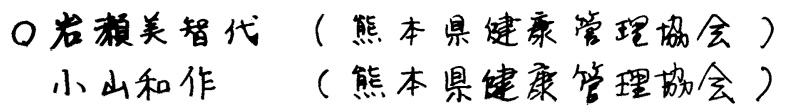

（はじめに）私供が焦本県下で行なっている絵合的な健康部断の中から 昭和 49 年度a受診者8,661人（男性2,069人，女性6,582人）の貧血检查成積志 もとにした鼻血の实態と、先に熊本農村医学研究会が行なった昭和42年か ら46年までの農村妇人の贫血检直成績とを比較、検討し、号の释年的变化 を子たのでここに辄告する。梌直项目は血色素量测定、判定は男性13.0 秋 未满、女性は12.09的末满を盆血とした。

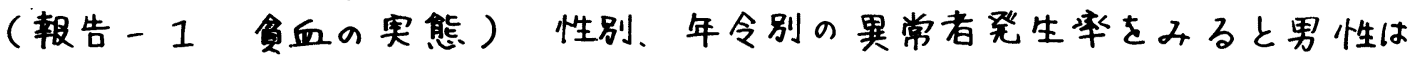
加令と兴に鿖血倾向となり、女性では40夫代に異血者が多くなつている( 四-1，2）。又、季節的には冬埸に釡血異常者が減少している:とはあきら かである(因一ろ)。娥種别に贫血発生率をみると、男女とも为一種兼業震

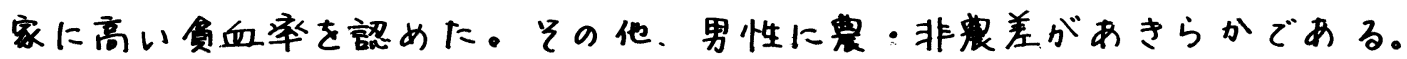
(回-4)。次に都市（男性438 名，女性355名) と農村(男性301名，女 性/714名) を年令橉成，梌查季節等を考虑して比較してみると、女性では

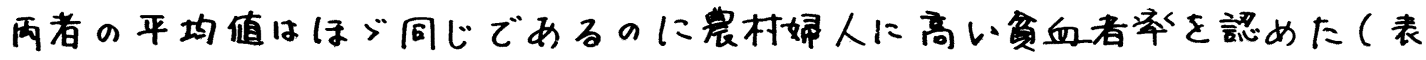

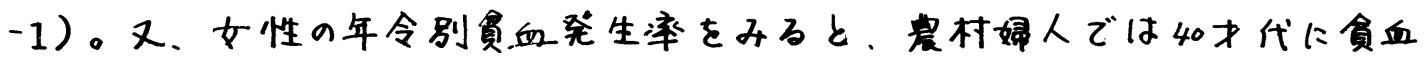
者が为いのに対し、都市に少ないといつた、はつたく連う会血発生率形熊

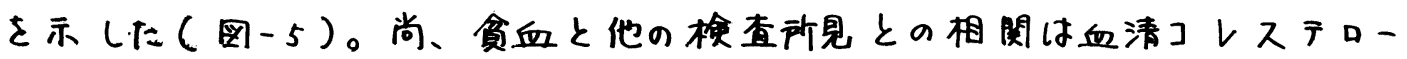
ル值が筫血者に低い烦向を示した心は、䀒楼能，血清中性脂肪等有意の差 は琵めなかった。

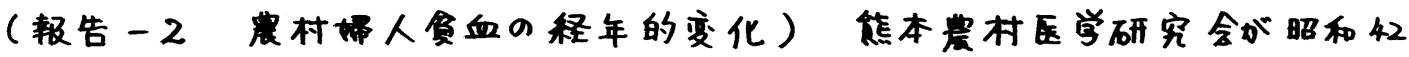

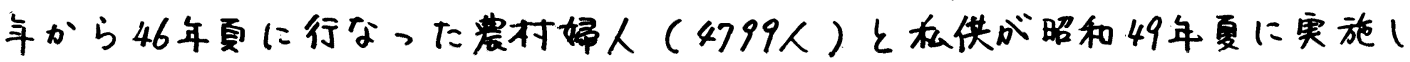

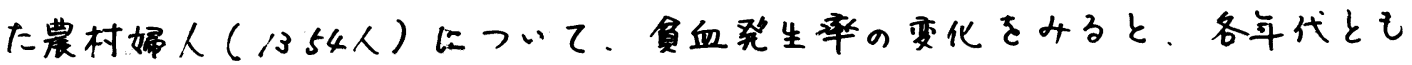
明らかに减少しており、特に若年属、改善が著しい(因-6,7８）。またそれ を各地区别にみると、以前高率を詪めた松棉，三角地区等に改善が著しく 全体として地区差があまりなられなくなった（因一）。また会血と高血压

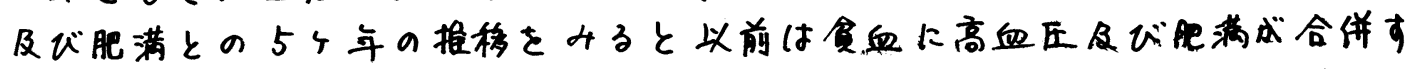

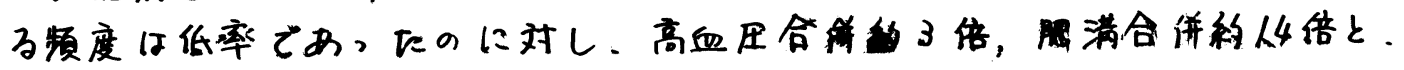
急速に高くなつろいる(国一10)。

(士すび) 1。昭和49年度心於ける会血者率は、男性43\%，女性143\% 女。 以前に比ベ减少はしたが、いまなお女性の主な疾病のけつである。

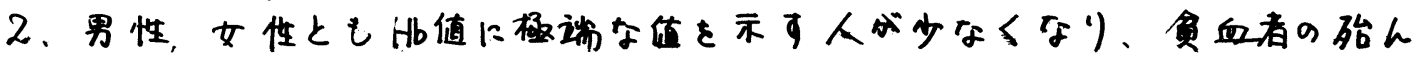
ぞの人が境界城に集まつている。

3、今回の成紿で贫血高血圧合併症及び肥满合併症の人が增加している事 


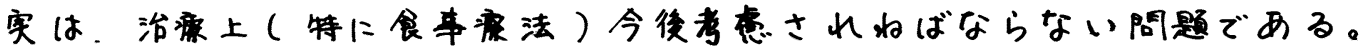

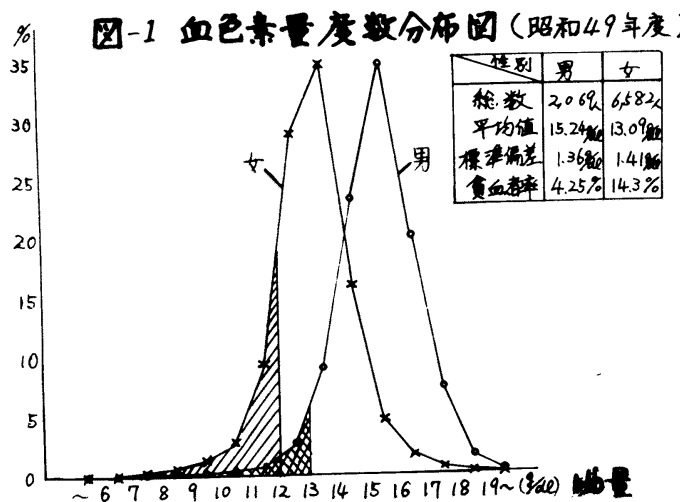

因. 2 年令别血色素量具常者辛
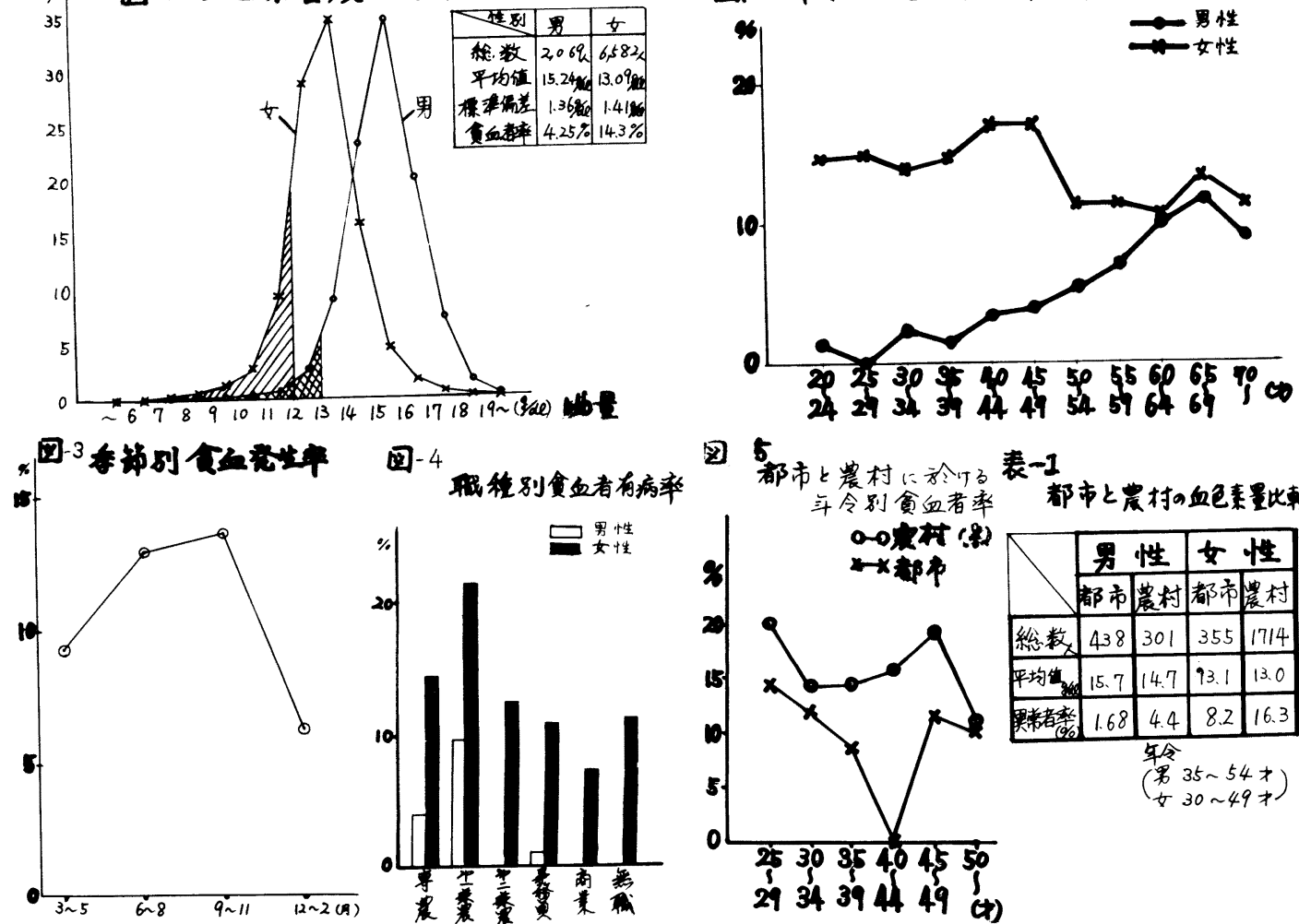

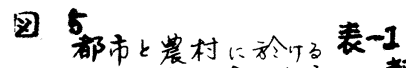

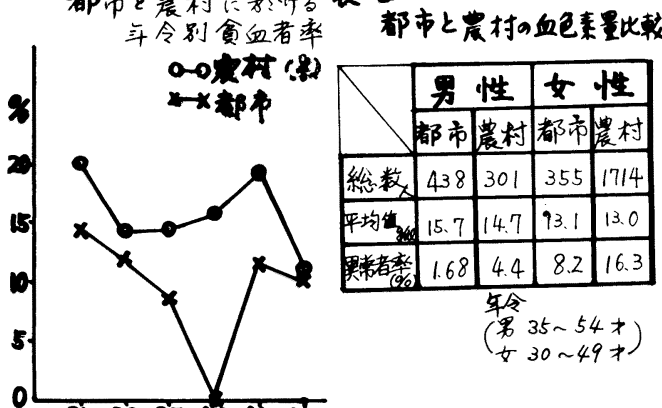

253035404550 293439449 (t)

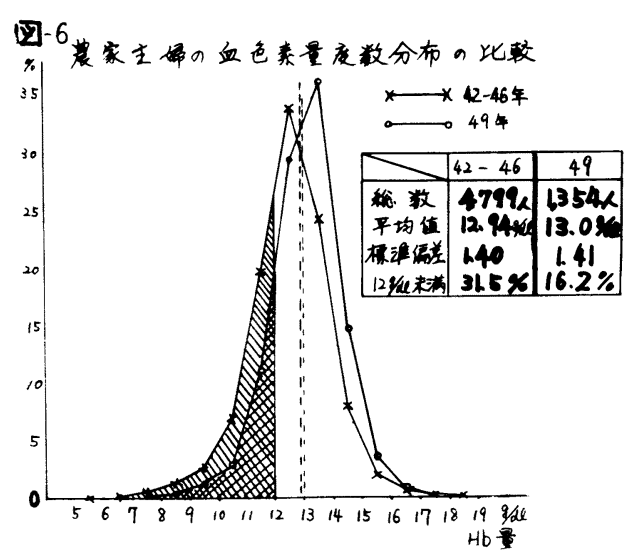

田.7貧血老生率a経年的变化

回8 年度别, 年令别食血登生率
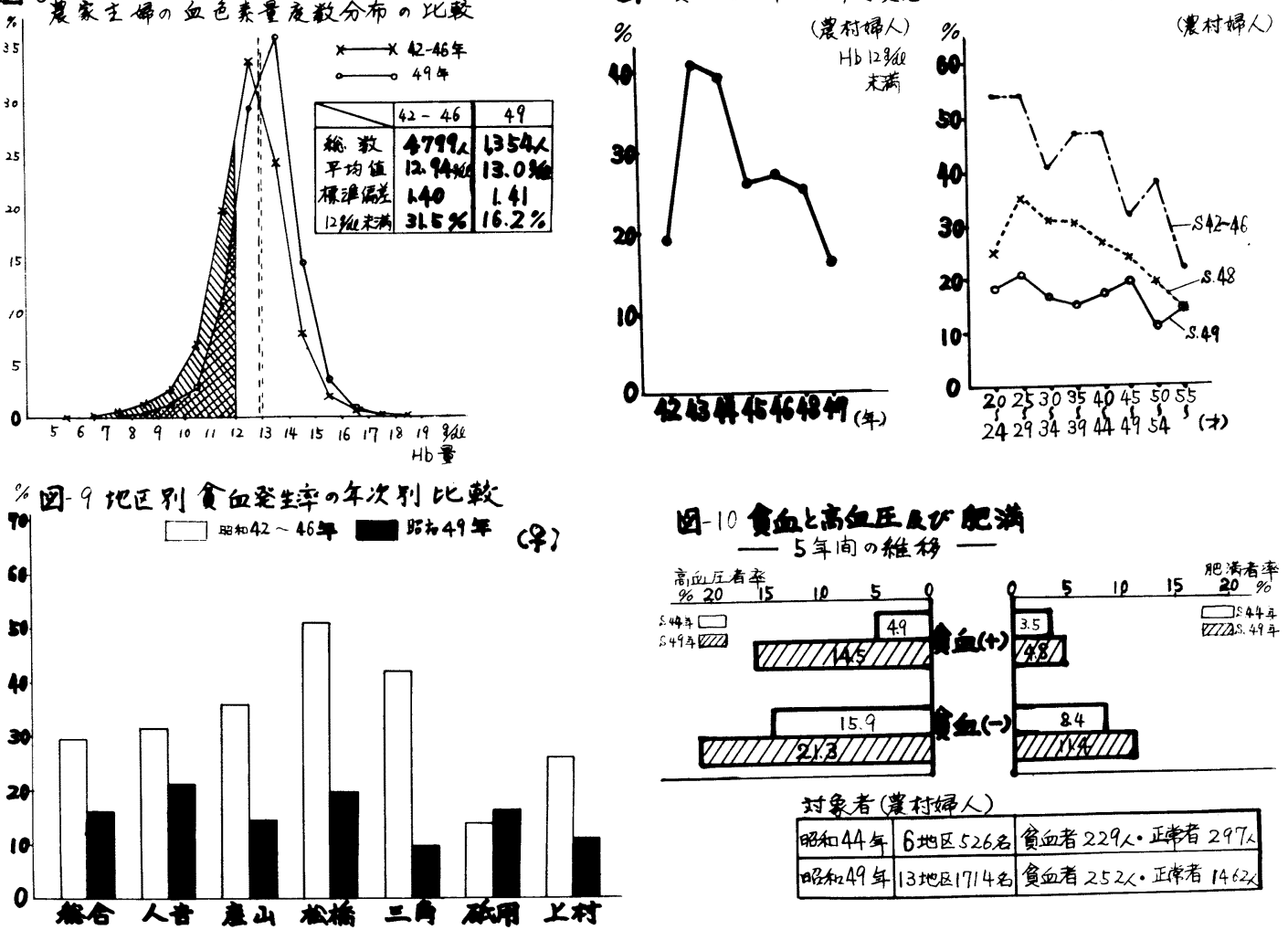


\section{変化につんて（第 3 報）}

$\bigcirc$ 横山孝子、笠置英子、田中範子、高山千恵子、 佐々木弘子、樫山美智子、市川順子、桜井賢彥

(長野県・佐久総合病院)

八千穂村の全村健康管理活動は、今年で を開始した昭和 34 年頃から、日本の経済は急速に成長孝しはしめ、農村に兼業化

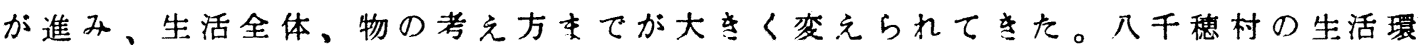
境要因も本た、図1の如く、総人口の減少、所得の增加、特に農外所得の大巾古

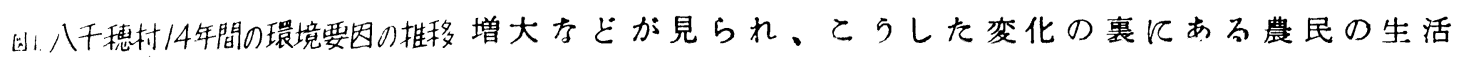

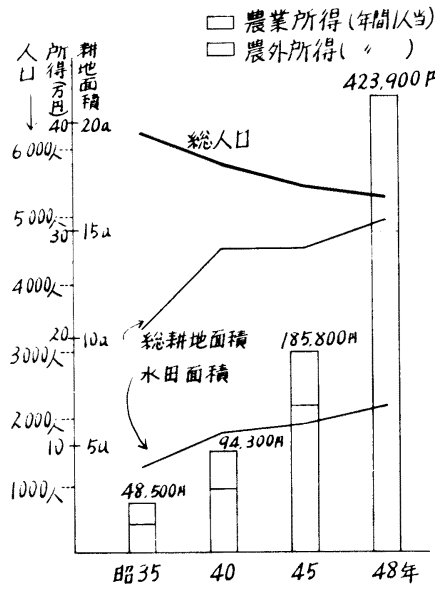
や健康面を追求すると共に、地域く万五の健康管理活動

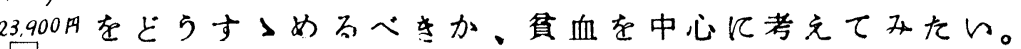

\section{1, 調査方法}

調查対象は表 2 の如くて、昭和 45 年〜 49 年の検診結果 で、負血のあつた人と、んつも正常であつた人について 45 年から48年への生活要因の推移を比較した。

貧血の判定は、WHOの基準飞徒い、Hb值て男 $13 \mathrm{~g} / \mathrm{d} \ell$ 未满、女 $12 \mathrm{~g} / \mathrm{a} \ell$ 末满を責血とした。

2 , 調查結果

(1)全村の 5 年間の貧血者率の変化村全体の各年度の 貧血者率は表2 の如くでる。48年49年度に男女ともか

表1、調查対象人崱

\begin{tabular}{|c|c|c|c|c|}
\hline & \multicolumn{3}{|c|}{ 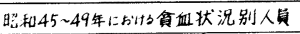 } & \multirow[b]{2}{*}{ 合計 } \\
\hline & $\begin{array}{l}\text { Wつも正常 } \\
\text { (贫四なL) }\end{array}$ & $\begin{array}{l}\text { 回のम } \\
\text { 貟衈 }\end{array}$ & $\begin{array}{c}2 \text { 回以上 } \\
\text { 貟血 }\end{array}$ & \\
\hline 男 & 1.229 & 54 & 29 & $1,302^{人}$ \\
\hline 女 & 1.406 & 146 & 103 & 1.655 \\
\hline 計 & 2635 & 200 & 132 & 2.957 \\
\hline
\end{tabular}

国2. 性・年代别会血率の年次推移

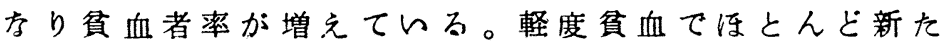
に負血にるつた者であるが。不況をどによる職業の変 化も関係していると思われる。性 ・年代別の賽血者率 の推移を図2に示した。 5 年間平均でみると、やはり 高令者と女性の20〜40才代に多くなつている。

(2) 貧血の原因

5 年間に重血のあつた人 319 人につ w086420 0 2 $46810121416 \%$ \%

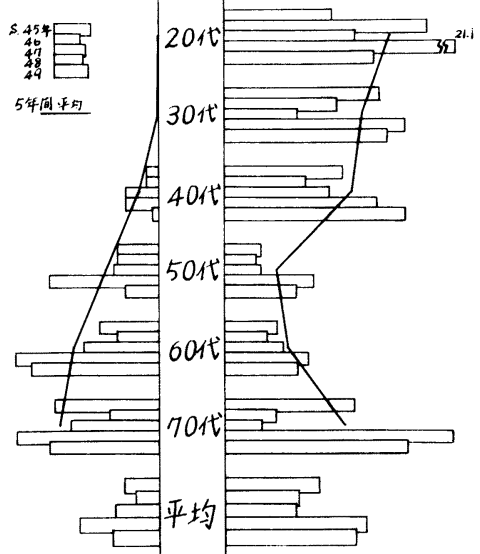
因となつていると考えられた疾患をあげると表了の如 くである。男で2回以上も賓血が出現するよ5な人に 表2.八千穗材におけ最近5年間嘪血者率の推移 は、やはり

\begin{tabular}{|c|c|c|c|c|c|c|}
\hline & & 年度 & 6年度 & 7年度 & 48年度 & 495 \\
\hline & & $\frac{24}{877}$ & $\frac{16}{810}$ & $\frac{28}{824}$ & $\frac{46}{752}$ & 22 \\
\hline & & $7 \%$ & $2.0 \%$ & $3.4 \%$ & $.1 \%$ & .0 \\
\hline & & $15.6 \% / d$ & $15.7 \% / d d$ & $15.1 \% / \mathrm{de}$ & $5.0 \mathrm{~g} / \mathrm{dl}$ & $15.2 \mathrm{~g} / \mathrm{de}$ \\
\hline & & $\frac{89}{1236}$ & 108 & $\frac{63}{1153}$ & $\frac{13}{1036}$ & 56 \\
\hline & & & 5.7 & & 10.8 & \\
\hline & & & & 136 & $133^{4}$ & 134 \\
\hline
\end{tabular}

胃潰瘍をど 身体的孛原 因があ場 合が多いて とかわかる。 女性では、 疾患をどよ 
り、栄食その他生活側からの原因も多いと考えられる。

(3)生活要因との関係図3,4,5,6亿より、生活状況の45年加 48 年への推移 を比較すると、乳卵摄取量では、男の2 回以上貧血者が48年には摄取を增量し ており、筫血改善のために努力していると思われるが、他の群では正常者に比へ、

貧血者が摄取が少ない傾向である。

総所得は、男のI回䞄血者を除、他 は全て負血者が正常者より低い。耕地面 積で、全村の平均より筫血者に、は人 当面積が多く、48年にはさらにとれが増 加している。少をん人手で農業を多くゃ 万無理が考えられる。

本人の職業では、筫血者の方に「農業 か主て、日雇ん、ハート、内職をする」 とい5人がく、特に男の暑血者に48年 にゃ〉てれが增えているのが注目される。

\section{$3 ;$; 女め}

社会経済的な動きが、確実に農村の生 活や健康飞影䡬を与えており、地域ぐる みで問題を見つめ、栄盖グループをどの 地区組織の活動が、更飞高本万上5啓蒙 する必要かあると思われる。

16 年間の健康管理活動の中で、八千穂 村民の1人当り国保医療費（年間）が、 他町村と比へ著明飞減少しているととは 手おくれ病の減少を意味し、早期発見、 早期治療の習慣がいつの东にか身につん たと考えてょいと思 5 が。健康よりも経 済優先の風潮の中で。これを広範囲に進 めるには、現在の医療制度の実状含め。 末だ、多くの問題が残されている。

因6. 耕地面積(世带认当)の变化の比較

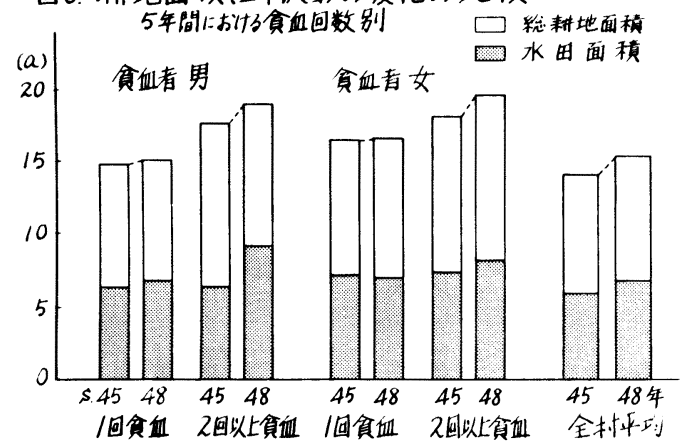

\section{表3. 食血の原因}

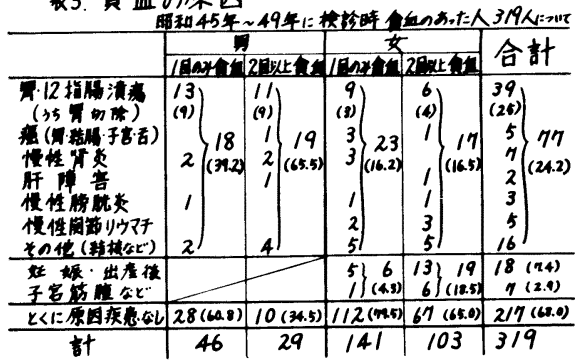

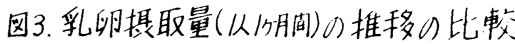
5 年间の頜但回数别

$\square$ 牛乳㟄乳

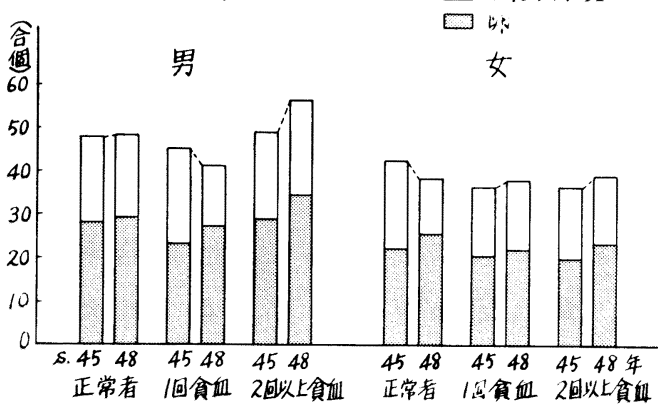

图4.年間/人当所得の推移の比較

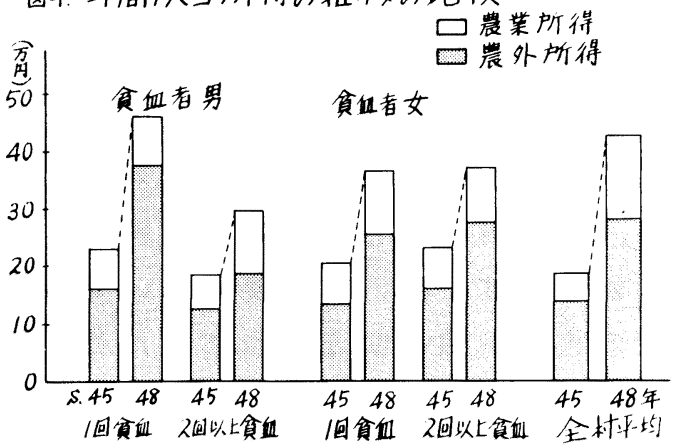

图5. 本人の䎳鄴の推移の比較

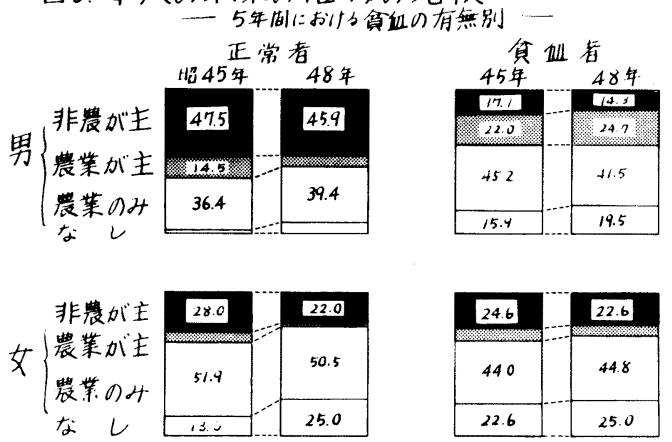


228. 木島平村における血の助向について

長野県厚生連北信総合病院

黒谷幸子泉山富雄他

〔はじめに〕

過去 10 年間、健康管理検診を実施 してをた木島平村において、昭和49 年度が 48 年度に対し負血者率低下、 血色素量の上年を見をのでとこに報 告する。

[成績〕

表 1 のように昭和 49 年度は 48 年度 飞対 L, 平均血色素量男 $0.6 \mathrm{~g} / \mathrm{d}$ 工、女 $0.58 /$ d I 上昇を見、貧血者率子著 しん変化を見せた。

図1. 2 年令別飞見ても男は年令と共 に、貧血傾向が高まり、女では働き さかりの30〜40才代が高く、曲線の 傾向は 49 年 48 年と似ているが、全体 に改善された。農村の筫は。会生 活のアンバランス、労働の過重等が 主な原因として考えられているので 私達は検診時、筫血の人達に対して は、食事を中心として毎年指導をし ているわけだが、49年度におんて個 別の指導が数年間なされていたとと が効を奏したとも考えられるい、及 出稼者が少なくなり、労働が 48 年に 比較し、軽くなったとも考えられる 48 年度貧血者、及び 48 年 49 年と $\mathrm{H} \mathrm{b}$ 值が $1.0 \mathrm{~g} /$ d I以上の変動のあった正 常者に対しアンヶート調査をしたと ころ表 2 のように食事の注意をして よくなった人が合計 405 人で。食生活の注意によりHb值の上昇を見るととがわか っ。

図3. 4、部落別に貧血者率を見ると数部落を除んて、大部分の部落の貧血が改善 された。改善された部落の中には、保健婦に自分達の部落の中に貧血が多いとと 
を指摘され、母子衛生部長が中心となり、衛生 自治会、婦人会の話し合いの中で、自主的な負 血改善運動が 48 年発足した。具体的には、役場 農協および当病院の協力老得ながらの貧血検診 料理講習会などを開らを、49年度には著しい改 善を見た。今年度になり、その一部落の貧血改 善運動が、他の部落にも刺激を与えるととにな り、農協を通してのレバ一共同購入。緑黄色野 菜を積極的に作ったり、食へるようにするとと を村くるみで央施するよらになった。 〔むとめ]

貧血につんては食事ばかりでなく、労㗢の問

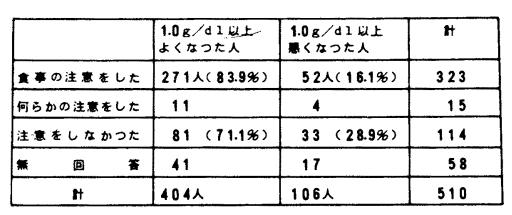

\begin{tabular}{|c|c|c|c|c|}
\hline & $\begin{array}{l}1.0 \mathrm{~g} / \mathrm{d} / \mathrm{LL} \\
\mathrm{\alpha}<\mathrm{s} \partial \mathrm{A}\end{array}$ & 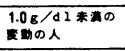 & $\begin{array}{l}1.0 \mathrm{~g} / \mathrm{d} 1 \mathrm{LL} \\
\mathrm{C} / \mathrm{s} \partial \mathrm{t}\end{array}$ & it \\
\hline 苚の注をした & 134 & 98 & 8 & 240 \\
\hline 何らかの注家した & 5 & 7 & & 12 \\
\hline 注㫣しかかつた & 12 & 17 & 3 & 32 \\
\hline 製 回 & 8 & 6 & & 14 \\
\hline it & 159 & 128 & 11 & 298 \\
\hline
\end{tabular}
題、季節の問題など、まだをだ住民と一緒に考 えていかなければならないと 思らが。ととに自分達の健康 は自分達で守ろらとする意識 が芽ばえてをたととは、今ま での木島平村の歴史にはない とんってもんんほどで、自発 的な、との運動に対 人、目を みはるべを゙と思らます。負 血改善運動を手がけたととが きっかけとなって、しだいに

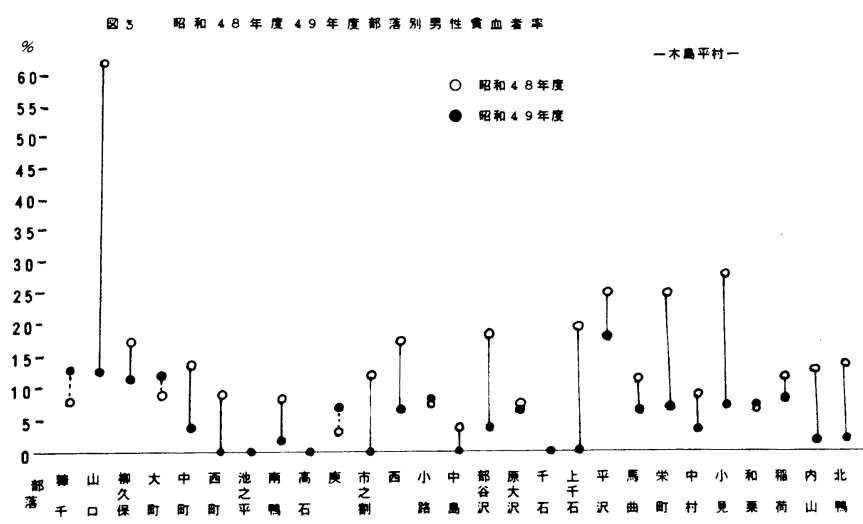
総合的な生活の改善、合理化 に発展していくよら、私達は 側面から援助していかなけれ ばならないと思う。単に村の 健康作りは、健康管理検診だ けでなく、そこにくらにをか える活動が、上かも、与をる のではなく、自ら実施する意 欲をもって住民加自主的飞や って行くてとによって生まれ るものであり、住民と行政と

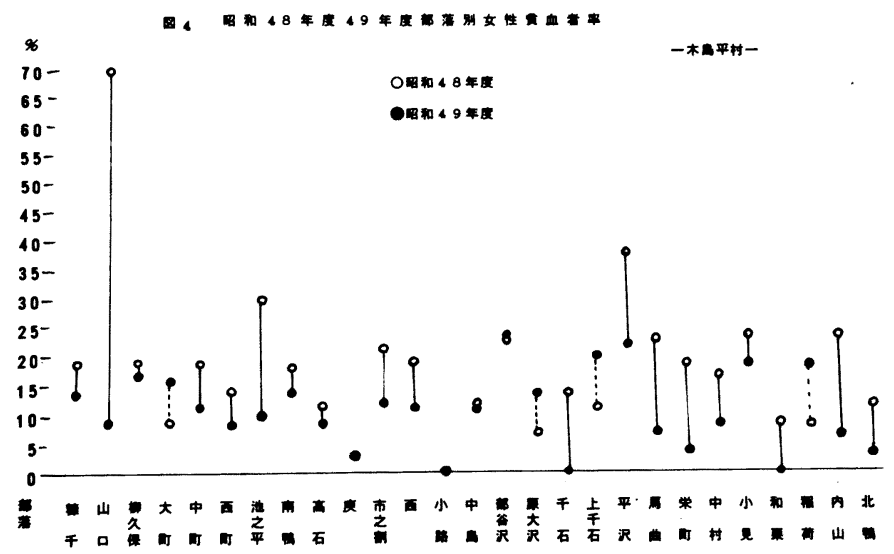
医療てして他の関係機関が一 体となってはじめて健康作りされるように疗るのが望むしんととだと思う。 
1 は じめ

当県では、農協の婦人部が中心となり、農村に働く人々の健康状態、なかでも薄い血問題を強 く取り上げ当協会が協力し、血色素量、血球容積を中心とした検診が昭和 46 年度より実施され ている。当初は、受診団体個々の成績のみを重視し指導の目安として地域に還元してをたが、 数年その成績を追つてみると各地域における極端な成績のバラッキが生じてをた。営農形態、 季節、年令等により成績の変化のみられるととは、すで報告されているてとであるが、それか ら全国各地区の傾向を知るとともに、当県における検診データ一の集計・分析が急がれている。 今回は、一つの手掛かりとして地域的にも遠隔て、営農形態も異なる県内 3 地区を選び、血液 性状の季節的な変動を追つてみた。

2 研究方法

県内上り 3ブロックを選び20〜 59 オまでの男女を調査の対象とした。Aブロックは県北に 位置し畑作及び山林が主、Bブロックは県中央部に位置し県都 M市の近郊農業、Cブロックは県 南部に位置し水田(䅛作)であるとともに近郊及び遠隔地の野菜栽培が盛んである。

表 1 調査対象地区の営農形態及び検査人数

\begin{tabular}{|c|c|c|c|c|c|c|c|c|c|c|c|}
\hline \multirow{2}{*}{\multicolumn{2}{|c|}{ 多多耕作面積 }} & \multicolumn{5}{|l|}{ ha } & \multirow{2}{*}{\begin{tabular}{|l|} 
農 \\
専 農 \\
\end{tabular}} & \multicolumn{2}{|c|}{ 家 数 } & \multirow{2}{*}{\multicolumn{2}{|c|}{ 検 查 人 数 }} \\
\hline & & 水 田 & 果 樹 & 畑 & {$\left[\begin{array}{l}E=\pi \\
\text { 吸 }\end{array}\right.$} & 他 & & 第一種兼 & 第二種兼 & & \\
\hline $\mathrm{A}$ & $3,36 \frac{6}{3 a}$ & 760 & 8 & 2,331 & - & 267 & 188 & 1,068 & 1,171 & 547 & 1,198 \\
\hline B & 6,062 & $4,1 \bigcirc 4$ & 371 & 601 & 974 & 12 & 443 & 1,854 & $1,6 \quad 31$ & 616 & 2,870 \\
\hline $\mathrm{C}$ & 9,088 & 7,496 & 128 & 702 & CE" $=-$ & $\begin{array}{l}\text { ハ⿱宀八大亏 } \\
759\end{array}$ & 638 & 2,791 & 3553 & 328 & 2,137 \\
\hline
\end{tabular}

調查期間は昭和 4 8年〜 49 年の 2 ケ年とする。(春：3〜5月、夏：6〜8月、秋：9１1月、冬：12〜2月）

検査項目は、血色素量（シアンメトへモグロビン法）、血球容積である。

3 結果

表2 各ブロック別 血液性状の季節的推移

\begin{tabular}{|c|c|c|c|c|c|c|c|c|c|c|}
\hline $\mathrm{Ht}$ & $\begin{array}{l}\text { ブロ } \\
\text { ック }\end{array}$ & 春 & 夏 & 秋 & 冬 & $b$ & $\begin{array}{l}\text { 春 } \\
\end{array}$ & 夏 & 秋 & 冬 \\
\hline \multirow{3}{*}{ 子 } & A & $9 \pm 3.1$ & $43.8 \pm 3.8$ & $45.1 \pm 3.5$ & $46.7 \pm 3.2$ & & $5.0 \pm 10$ & $14.7 \pm 1.3$ & $15.6 \pm 13$ & $56 \pm 12$ \\
\hline & $\mathrm{B}$ & 3 & 42.6 & .0 & $.0 \pm 3.6$ & & $149 \pm 1.2$ & $14.0 \pm 14$ & $14.5 \pm 1.3$ & $144 \pm 1.1$ \\
\hline & C & $44.1 \pm 3.5$ & $41.7 \pm 4.1$ & $42.5 \pm 4.0$ & $44.4 \pm 3.9$ & & $14.4 \pm 13$ & $13.7 \pm 1.2$ & $14.0 \pm 13$ & $14.7 \pm 18$ \\
\hline \multirow{3}{*}{ 女 } & $\mathrm{A}$ & $39.5 \pm 3.9$ & $36.8 \pm 3.3$ & $39.2 \pm 3.6$ & $40.3 \pm 4.0$ & \multirow[b]{3}{*}{ W } & 12.8 土 1.4 & $12.2 \pm 1.4$ & $13.0 \pm 1.2$ & $13.4 \pm 1.2$ \\
\hline & $\mathrm{B}$ & $38.8 \pm 3.8$ & $37.0 \pm 3.4$ & $380 \pm 3.2$ & $38.2 \pm 3.7$ & & $12.7 \pm 1.4$ & $12.1 \pm 13$ & $12.5 \pm 1.2$ & $12.5 \pm 13$ \\
\hline & C & $38.0 \pm 3.3$ & $35.7 \pm 3.5$ & $36.3 \pm 3.3$ & $39.0 \pm 3.8$ & & $12.2 \pm 13$ & $11.9 \pm 1.5$ & $12.0 \pm 1.2$ & $12.4 \pm 15$ \\
\hline
\end{tabular}

各ブロック別の血液性状の季節的推移をみると表一2の如くである。これょり血色素量及び血球 容積とも夏低く、冬に高い值であるととが認められるが、その変動の程度が各ブロックにょりか なり相違のあるととが明らかにされた。特に男女ともAブロックでの成積が他ブロックに比較し て良く夏季に一時的な低下はみられるものの秋季にかけての快復度は非常に早い。夏季に著しい 


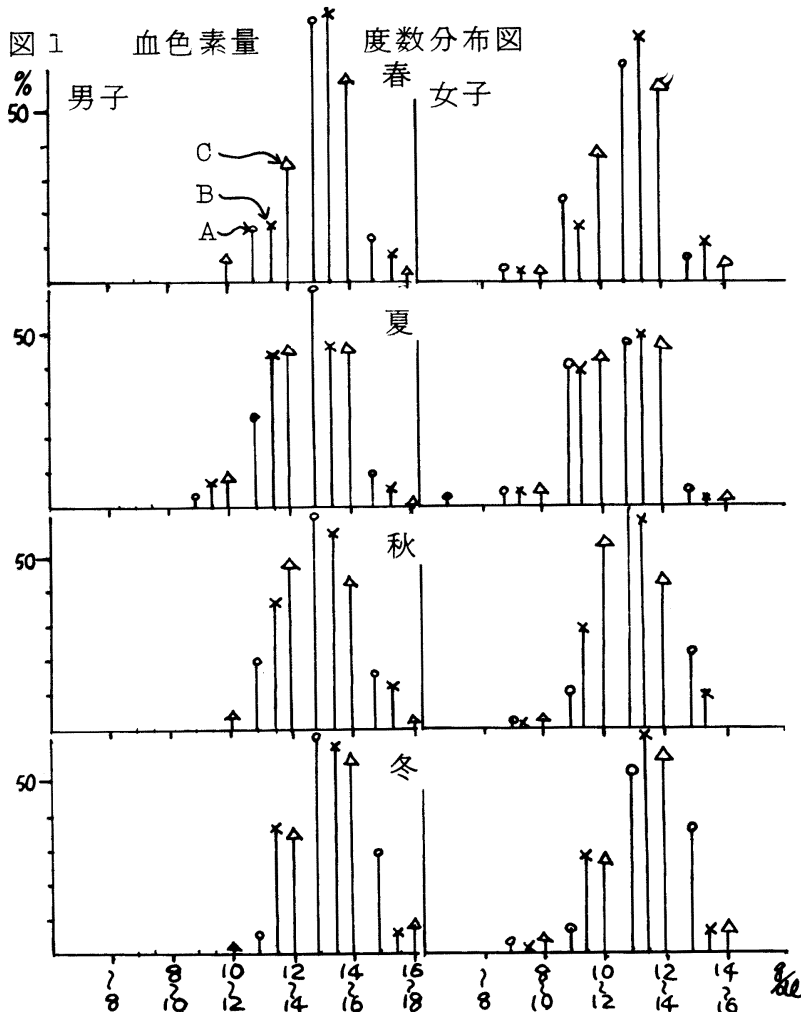

低下を見せるのはCブロックであり、こ こでは秋季にかけての快復度も遅くなつて らる。血色素量の度数分布は図一1の 如くである。とれより各ブロックの季節 的変動が明らか飞示される。

図2より、男子ではAブロックと比較す ると、 B 及び C ブロックの変動傾向が顕著 である。B及びC ブロックでは 40 代, 50 代 几夏季の血色素量低下が明らかである。 女子では、各年代ともその差はあまり明ら かではなが、若い年代程、血色素量の低 下がみられる。

\section{4 考察}

今回の成績よりブロックどとの比較では らずれも夏低く冬高い血液性状を示したが、 それぞれにパターンも異なり程度の違らす みられた。特に注目されたいのは、A

図2 年代別にみた各ブロックの血色素量の季節的推移
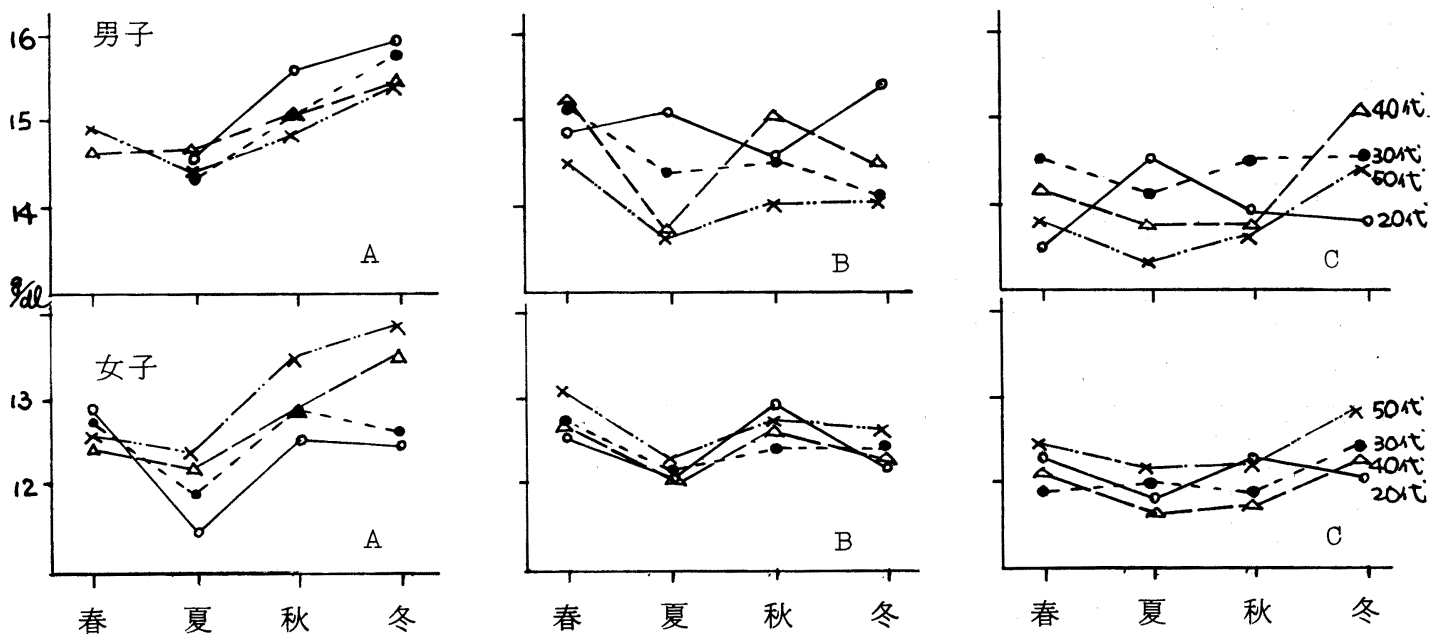

ブロックは他のブロックに比較して、高值を示したというととである。このブロックは、畑、山 林を主とした兼業農家であり県内でる出嫁ざ者多数の低所得者地帯である。 従来多くの報告 が行なわれている貧血の成立要因として、米の収獲量が少なく、低所得者層及び兼業農家といら 点からみた限りでは、今回の成績は全く逆の結果を示した。 貧血の発生率 (W H O 1968 Hb

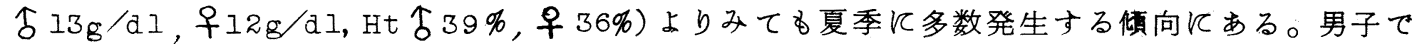
は40〜50代に激増、女子においては、若年層程低下がみられる。更に女子の発生率が男子の約 2 倍という点等、地域の健康管理指導上の多くの問題点がうを医りにされたと思う。 


\section{泰薬中毒 I}

317.

$S \cdot S \cdot$ オプレーターの健康管理方式に闺する一提案

（特に血清及で血球コリンェステラーゼ值を中心として）

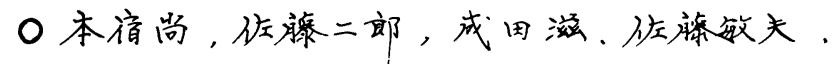

(福息景。公立湶田䓡合病院)

儿、目的、昭和46年强毒性有栈燐剂パラチ才ンの仗用禁止を国が決定し

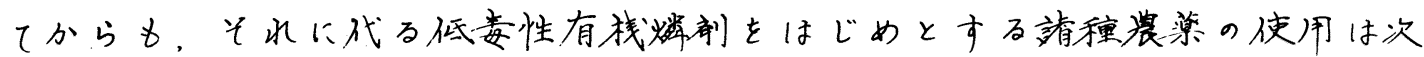
第以增加す万傾向にあり、労仂力の節琙，生座性の向上の二点からだけ見

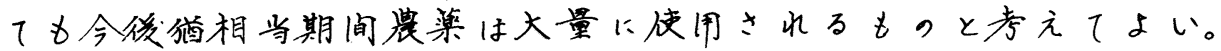
一方装真使用による副座物として使用省口急性中妻，作物における残留、 環境污染の问题等が生じてきた。低毒性有栈燐剂の慢性中毒例は現在

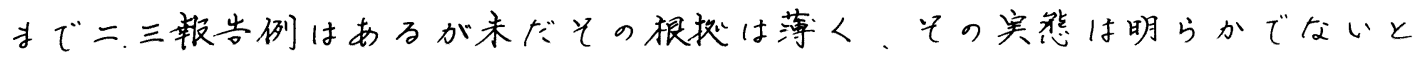
云ってよい。当院においても自殺例を含子誤即誤用例によ及急性中毒 例にはしばしば遭遇するが明碓な慢性中毒例の经邪はない。

そ己で我及は昭和 4 b年以降スピードスプレメー（SS）、才プレータ一を 中心とする健康調查を試从。はたして彼等の中に有栈燐による慢性中毒忠 春と思内れる北のが存在するかどうか、又次の健争管理の現状がどうなっ ているかを追求した。才ぺレータ一を選んだ理由としては、宁の多くが

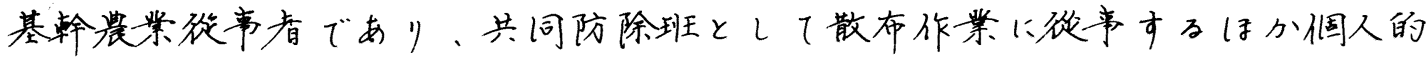

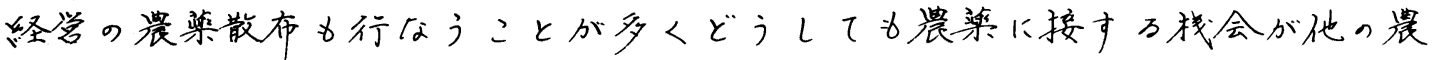
民に比して多いと考六たからである。

2、調查対象、福岛梁北部の果榯 地带を選んだ.才ぺレ一夕一の造 双基渠は表一に示すように管草な もので散布前の硬康診断等は全く 行ないれていない、散布從事年数 は表二の如く光の大部分が/年以 上で、パラチ才ン全盛時代から今

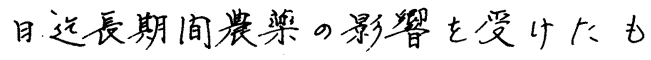
のが多い、出郭可数は10回から/5 回が大部分であるが/回の实労仍 時间の差、㑑人散布時)间の养に上 り表にあられれたい㑑人差が相当 あると考元られる。使用された震 桨はスミ千オン、ダイアジノン等 の有找燐製剂が多くとの他ケル七 ン、ニッソール、ポリオキシン モノックス、硫酸二コチン、栈㭜

表一、SSオプレータ一選双基淮

\begin{tabular}{|c|c|c|c|c|c|c|c|}
\hline 班，名 & 国胃 & 国自 & 桑折 & 湯野 & 野田 & 涌入 & \\
\hline 基㴖 & (橆思) & 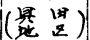 & & & & $A$ & $B$ \\
\hline 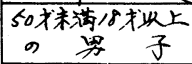 & & & & & 0 & 0 & \\
\hline 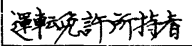 & & & & & 0 & 0 & \\
\hline 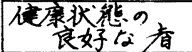 & & & & & 0 & & \\
\hline 裳祭後继省 & & & 0 & 0 & & & \\
\hline 農劦職真 & & & & 0 & & & \\
\hline 特になし & 0 & O & & & & & 0 \\
\hline
\end{tabular}

表二、対象オぺレータ一の年令别

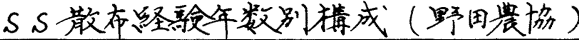

\begin{tabular}{|c|c|c|c|c|c|}
\hline 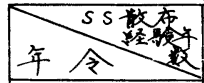 & 0几4年 & 5〜9年 & 10年以上 & 不敦 & 計 \\
\hline$\sim 19 才$ & & & & & \\
\hline $20 \sim 29 t$ & 10 & 12 & & & $2 \alpha$ \\
\hline $30 \sim 097$ & & & 57 & $\alpha$ & 59 \\
\hline $40 \sim 49 才$ & & & 76 & $v$ & 79 \\
\hline so $\sim \operatorname{sg} \neq$ & & & 26 & 4 & $\infty$ \\
\hline 60才以上 & & & & 1 & 1 \\
\hline 計 & 10 & 12 & 169 & 10 & 19 \\
\hline
\end{tabular}


油等实に多種多样を極めている。柃訡特期としては年2回实施ブループは

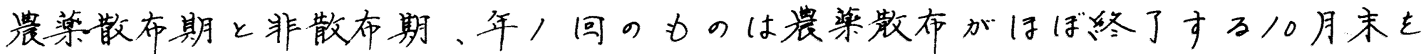
避んだ。

表三，血清ChE值

\begin{tabular}{|c|c|c|c|c|}
\hline 地区 & $\begin{array}{r}\text { 高庭低下 } \\
\sim 0.29\end{array}$ & 中第度砥下 & $\begin{array}{l}\text { 腈变低下 } \\
0.6 \sim 0.79\end{array}$ & $\begin{array}{l}\text { 正常 } \\
0.8 \text { 以上 }\end{array}$ \\
\hline 㫕 & & & ' & 7 \\
\hline 折 & & ' & 11 & $3 \alpha$ \\
\hline$\frac{2 x}{5}$ & ' & 7 & 7 & 5 \\
\hline 野 & I & 11 & $6 \alpha$ & 67 \\
\hline 南福禹 & & & 4 & 19 \\
\hline
\end{tabular}

了、湌查結果、(表略)、慢性肾炎 $\alpha$ ，

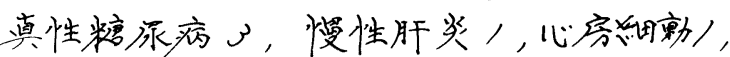
の具常者が発見され一時才でレータ一 より除外した。血清及で血球ch一E 值は表三表四に示す如く中等度以下の

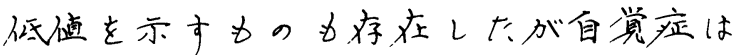
いずれの例で丮認められなかつた。

贯染使用時，非使用時年二回の柃查結果 では明らかに使用時の方が低值を示す ブループと、なんの候向も認められ视 いグループとがあり使用時に血清及び 血球Ch-E值が低值を示すと云うには仗

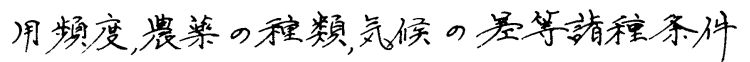
の吟味が更に仪要と思的水る。

4、まと也、た末たま当院で遭遇した 有栈燐剂誤崌例(表略) で血清Ch-E值の 方が敏试であることが实証されたので 共同防除省のフォアチエックとしては 先に示した检部内容上り血球Ch-E䛧の 测定を除之血消Ch一E值が低磕を示した ものにの从一週间装策に接する:とを 避け上火請種肝栈能以加六て元こで、は じめて血清及び血球Ch-E䛧の检查を案 施才及のが時间的にも经济的にも現实 性があるようである。

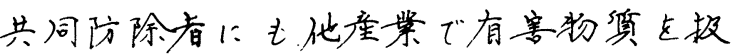
j労仂省上同程度の健康管理を法制化 すべきであることを提言したい。
表四，血球ChE值

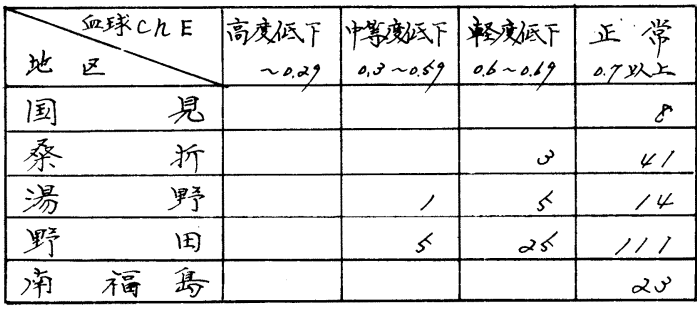

表五、血清Ch一E猚移 3月非使用时

8月使用時

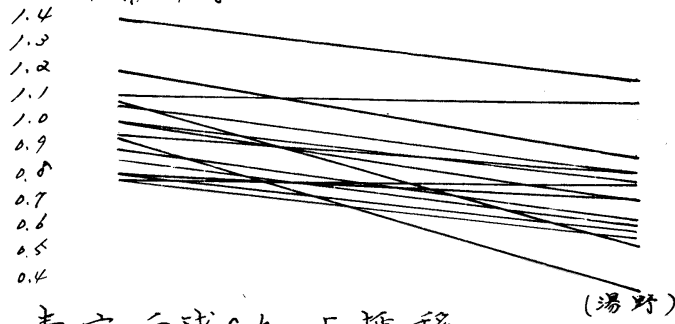

表六，血球Ch一E推移 3月非使用时

8月使用時

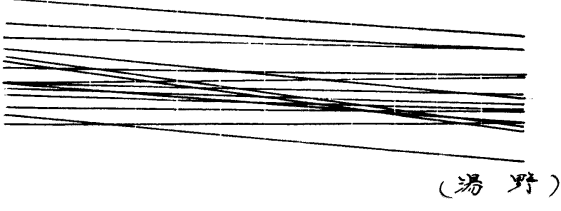

表七，血清c几一E推移 10月使用時 5)月非使用時

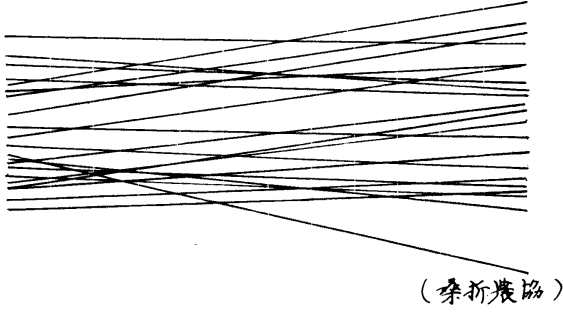

表八, 血球Ch一推移 $(R)$ 10月使用時

5月非使用时

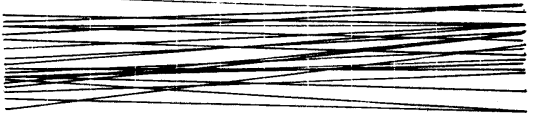

(条析裳坮) 


\section{S Sオペレーターの健康追跡調查}

$$
\begin{aligned}
& \text { 永田丕泉山富雄鐮田一男 } \\
& \text { 高野四郎斉藤正武他 }
\end{aligned}
$$

長野県厚生連・北信総合病浣

目的了

長年月多量の農薬散布飞従事する S S ペレーターの健康状態を、前年度飞ひ きつづき追跡調査し、農薬慢性中毒発見の手がかりをるぬる。

\section{対象了}

48年と同じ中野地区オペレーター41名を主たる対象とに、比較の対照として、 49年はじめてSS検診を開始した 中野地区外オペレーター124名を 加えた。

\section{方法了}

中野地区は前年度飞㹸ひとに く、対照地区は血液化学検査の一 部と脳波検査を省的た。

調 查時期了

中野地区は49年 5 月, 7 月, 12 月飞 3 回、対照地区は49年7月下 旬〜 8 月上旬飞 1 回。ただに脳波 検査岋非散布期、49年4月上旬飞 行った。

結果了

1)。中野地区では、40年に比に 49年には、オペレーター数の減少平 均年令の上昇( $32.4 \sim 41$. 牙) S S 散布面 積の減少が著明である。S S の機 種をみると、との2〜3年、中野 市全域飞、個人防除用小型 S S が 急速江普及した（図 1 ）。共同防 除組織つ衰退。農薬散布個人化が 著明となった。

2)。中野地区受診者減少( 48 年 $57 \rightarrow 49$ 年 41 ) の原因を調査すると 胃がん死亡1，慢性肝障害で果樹 生産廃止 1 , 共同防除脱退 4 , 離 農あるいは生産転換 4 , 計10名が

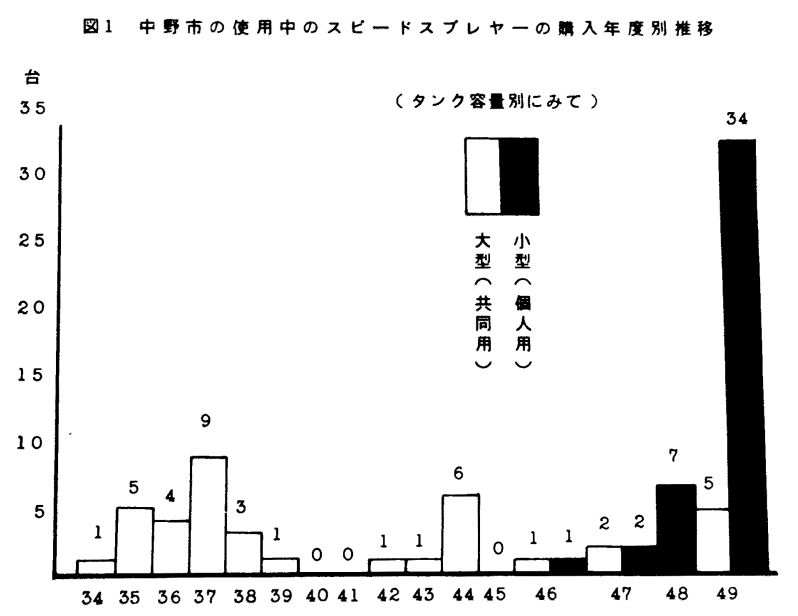

\begin{tabular}{|c|c|c|c|c|}
\hline & 5 月 & $\begin{array}{l}\text { 地 } \\
\text { 8月 }\end{array}$ & $\begin{array}{l}\text { 区 } \\
12 \text { 月 }\end{array}$ & $\begin{array}{c}\text { 対照地区 } \\
7 \text { 月 }\end{array}$ \\
\hline $\mathrm{b} \sim 13.9 \mathrm{~g} / \mathrm{d} \mathrm{l}$ & $35.5 \%$ & $29.7 \%$ & $4.0 \%$ & $29.0 \%$ \\
\hline $\mathrm{H} \mathrm{b} \sim 12.9 \mathrm{~g} / \mathrm{d} \mathrm{l}$ & 16.1 & 10.8 & 0 & 7.3 \\
\hline 赤血球数 $\left(\sim 400\right.$ 万 $\left./ \mathrm{m} \mathrm{m}^{3}\right)$ & 3.2 & 2.7 & 0 & $x$ \\
\hline$\left(\sim 1 万 / \mathrm{m} \mathrm{m}^{3}\right)$ & 6.5 & 2.7 & 4.0 & $x$ \\
\hline$\left(\sim 4000 / \mathrm{m} \mathrm{m}^{2}\right)$ & 3.2 & 2.7 & 0 & $\times$ \\
\hline 镊度低下 & 19.4 & 8.1 & 16.0 & 11.3 \\
\hline Ch $\mathrm{E}$ 人第度低下 & 0 & 2.7 & 0 & 0.8 \\
\hline G P T $(36 \uparrow)$ & 0 & 0 & 0 & 1.6 \\
\hline GOT $(41 \uparrow)$ & 0 & 0 & 0 & 1.6 \\
\hline $\mathrm{ZTT}(12.1 \uparrow)$ & 0 & 0 & 0 & 0.8 \\
\hline $\operatorname{ALP}(10.0 \uparrow)$ & 3.2 & 2.7 & 0 & 8.1 \\
\hline LAP $(200 \sim)$ & 3.2 & 5.4 & 0 & $x$ \\
\hline ヒリルピン (1.0〜) & 6.5 & 18.9 & 4.0 & $\times$ \\
\hline$\gamma-\operatorname{GTP}(80 \sim)$ & 3.2 & 2.7 & 0 & $x$ \\
\hline OCT $(9.0 \sim)$ & 0 & $x$ & $x$ & $x$ \\
\hline 尿蟫白（虂性） & 3.2 & 0. & 0 & 0 \\
\hline$(" \prime)$ & 0 & 2.7 & 0 & 8.1 \\
\hline 潜 血( ”) & 0 & 0 & 0 & 4.0 \\
\hline 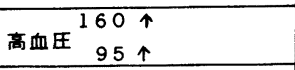 & 3.2 & 27 & 4.0 & 13.7 \\
\hline 受粀者数 & 318 & 37 名 & 25 名 & 1248 \\
\hline
\end{tabular}

表1模查成地区の比 2 ( 1949 年) 
退任。当人離農S Sだけ手伝 らが検晾飞出られぬ3, 組合 の連絡悪い3, 計 6 が受診不 能であった。

3 )。検殓結果は（表1）。 $\mathrm{H} \mathrm{b}$ 值、ChE值は両地区にあ まり差がない。中野地区では ZTT, G P T, G O T は異常者を 認めず、他の肝機能も好転にた。 防衣・防具着用率壮（図2）、中 野地区は対照地区より良好である 高血压者子対照地区にや〉高々

4)。脳波検查は散布期 39名（前 年度報告）非散布期 32 名の受猃者 中、2 回上子受診せる26名につん てみると、a)非散布期に挑的て散 布期より脳波異常所見の好転する のあり（表2）。b）異常所見の 種類壮表 3 , 表 4 のでとくで、徐 波出現が多的。脳波異常出現頻度 がかなり高いととは注目すべで ある。

結語了

1 。農莧共同防除組織江衰退 1 つつあり、個人散布が軽量S S で 行われる傾向にあり、再び農薬中 毒者の増加加懸念される。 2 。 $\mathrm{S}$ Sオへンーターには脳波異常所見 を呈するものが、かなり多く認め られ、これと農薬による慢性中毒 との関係はさらに検討を要する。

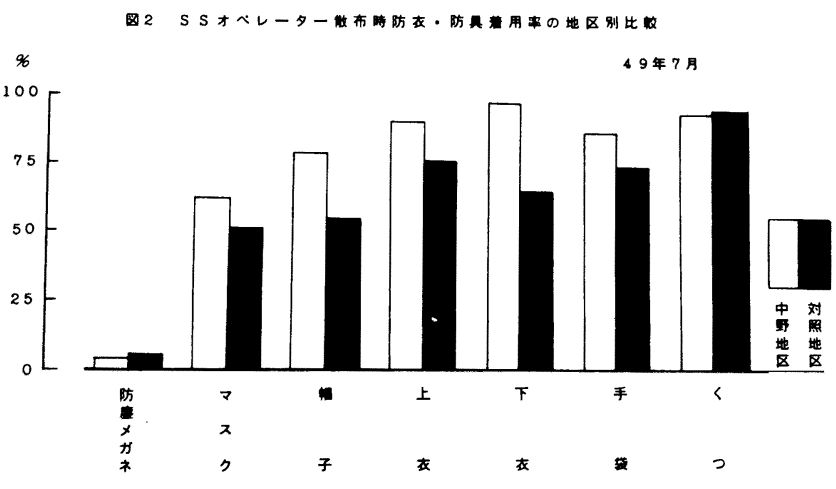

表2暴常脳波出現率 一両時期とも受路したものについてー

\begin{tabular}{l|c|c|c|c} 
& 異 常 & 境 界 & 正 常 & 受胗者 \\
\hline 散布期 & $\begin{array}{c}4 \\
(15.4 \%)\end{array}$ & $\begin{array}{c}9 \\
(34.6 \%)\end{array}$ & $\begin{array}{c}13 \\
(50.0 \%)\end{array}$ & $\begin{array}{c}26 \\
(100 \%)\end{array}$ \\
\hline 非散布期 & $\begin{array}{c}2 \\
(7.7 \%)\end{array}$ & $\begin{array}{c}10 \\
(38.5 \%)\end{array}$ & $\begin{array}{c}14 \\
(53.8 \%)\end{array}$ & $\begin{array}{c}26 \\
(100 \%)\end{array}$
\end{tabular}

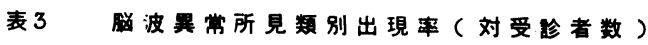

\begin{tabular}{|c|c|c|}
\hline & 散布 期 & 非数布期 \\
\hline 9 cps 未倳 slow alpha群 & $4(16.7 \%)$ & $3(11.5 \%)$ \\
\hline diffuse alpha群 & $7(26.9 \%)$ & $9(346 \%)$ \\
\hline 徐波出現高度群 & $6(23.1 \%)$ & $5(19.2 \%)$ \\
\hline 無作波 ( $\mathrm{spike，sharp)}$ & $3(11.5 \%)$ & $2(7.7 \%)$ \\
\hline 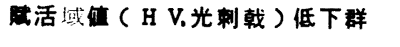 & $6(23.1 \%)$ & $3(11.5 \%)$ \\
\hline 左右差 & $4(16.7 \%)$ & $3(11.5 \%)$ \\
\hline 受 此 者 事 & $26(100 \%)$ & $26(100 \%)$ \\
\hline
\end{tabular}

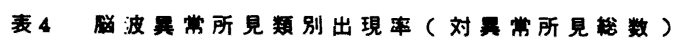

\begin{tabular}{|c|c|c|}
\hline & 散布期 & 非数布期 \\
\hline $9 \mathrm{cps}$ 末满alow alpha群 & $4(13.3 \%)$ & $3(12.0 \%)$ \\
\hline diffuse alpha群 & $7(23.3 \%)$ & $9(36.0 \%)$ \\
\hline 徐波出現高度群 & $6(20.0 \%)$ & $5(20.0 \%)$ \\
\hline 眐作波 ( $\mathrm{spike，sharp)}$ & $3(10.0 \%)$ & $2(8.0 \%)$ \\
\hline 活域值 ( H V. 光剩载) 低下群 & $6(20.0 \%)$ & $3(12.0 \%)$ \\
\hline 左右差 & $4(13.3 \%)$ & $3(12.0 \%)$ \\
\hline 掌所見数計 & $30(100 \%)$ & $25(100 \%)$ \\
\hline
\end{tabular}

住) d iffuse $\alpha$ 群： $\alpha$ 波の後頭倀位がくずれ、同期化倾向の強 いもの

活域值低下群：墖呼㖟または光刺戟により高振巾、徐波化 の強いもの 
319.震菜オベレータ一のアキレス腱反射について

○成田嵫, 本宿尚(福島景公立藤田紿合病院) 传々木盛德(福鳥景大原綜合病院)

星鹪落一郎福岛医大径生学教室)

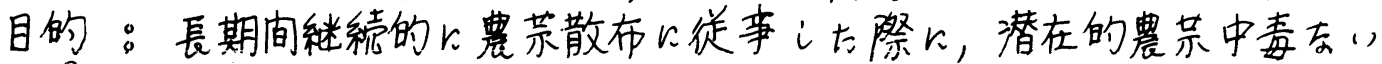

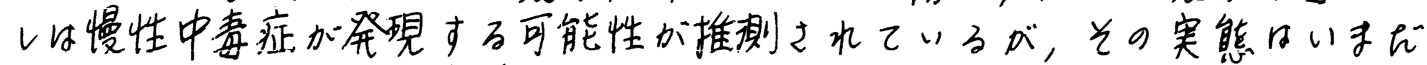
明らかでない。我々は䢅菜Operatoraアキレス腱反射（ATR）以具常か 站水るかどうかを検訣するため次の調查を行をつた。

方法: 䢅葉Operator (Group I) 115名（男），一般典民（Group II) 259 名（男39，女220）およu非曹健常者（以下健常者）409名 （男259，女150）を汶象とiて，Lawsonの方法潐にた装置によりATRの

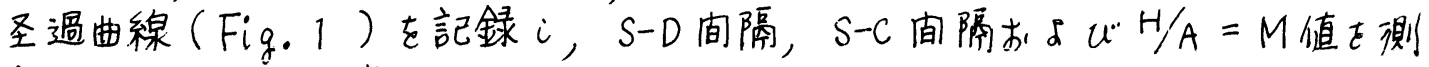

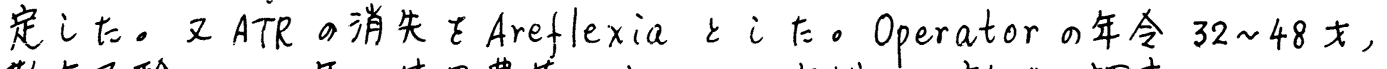
散布圣験1 $0 \sim 17$ 年, 使用農菜は主として有栈りン剂で, 調查は20 40日间

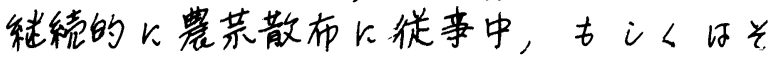
の直後に行寺つた。 Operatorにっいては 未梢血去よび若干の生化学的检索も同時 に行寺つた。

結果: (1)末梢血, 生化学的検查。沓 均值に異常は加的水去かつた。( Tab, 1)

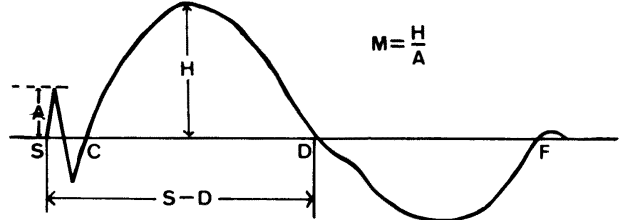

Fig.1. ATR Tracing Curve.

この詳細とついては, 今学会において本宿が報告しているが, 一般検查 からは明的か奇曹菜中毒例は加的水かつた。(2)ATRの平均值には了群の

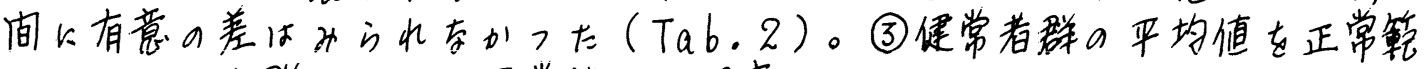

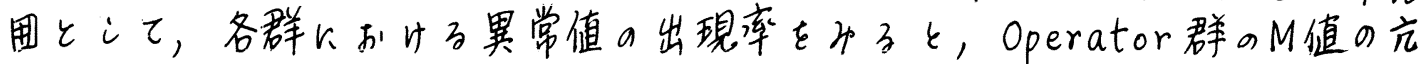

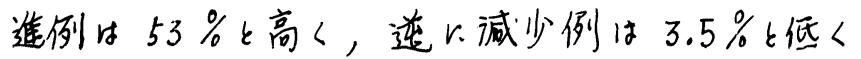
いづ水も有意の差を示之た（Tab.3）。

(4)生化学的検查項目と各ATR值口间的相闺 々係は的北夺かた。

考按: 腱反射a测定山神経・筇杙能を表

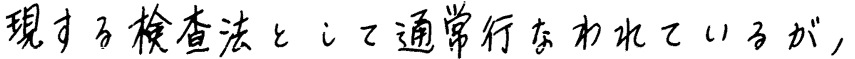
腱反射曲線吉詔睩することによってさら火詳 細去分析加可能を夺った。即古ATR曲線aj

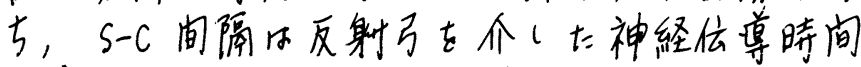
が含ま水ており，S一D间隔はS S C 间隔に筋收 縮時间巨加元长ものであ万。又M值はATR。 元進太いしは减弱を振幅比として表現门たも のである。今回の調查では，S-D, S-C両间

Table I. Mean Value of Laboratory Findings. 115 Operators.

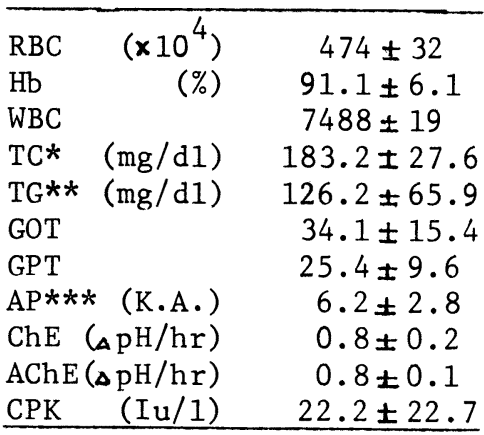

*Total Cholesterol

**Triglyceride

***Alkaline Phosphatase 
Table 2. Mean of S-D Interval, S-C Interval and M Value in Group I (Operators:Spraying Pesticides), Group II (Farmers:Non-Operators) and Healthy Controls.

\begin{tabular}{|c|c|c|c|c|c|c|c|}
\hline \multirow{5}{*}{$\begin{array}{c}S-D \\
\text { Interval } \\
(\mathrm{msec})\end{array}$} & \multirow{3}{*}{$\begin{array}{c}\operatorname{Age}(y r) \\
15-24\end{array}$} & \multirow{2}{*}{$\begin{array}{c}\text { Group } \\
\text { I } \\
\text { Male }\end{array}$} & \multicolumn{3}{|c|}{$\begin{array}{c}\text { Group } \\
\text { I I }\end{array}$} & \multicolumn{2}{|c|}{$\begin{array}{l}\text { Healthy } \\
\text { Controls }\end{array}$} \\
\hline & & & \multicolumn{2}{|c|}{ Male } & Female & \multirow{2}{*}{$\begin{array}{c}\text { Male } \\
238(106) \\
\pm 24\end{array}$} & \multirow{2}{*}{$\begin{array}{l}\text { Female } \\
248(55) \\
\pm 28\end{array}$} \\
\hline & & $\underset{ \pm 0}{260(2) *}$ & $\begin{array}{l}230( \\
\pm 10\end{array}$ & 2) & $\begin{array}{l}260(\quad 5) \\
\pm 17\end{array}$ & & \\
\hline & $25-44$ & $\begin{array}{l}261(67) \\
\pm 22\end{array}$ & $\begin{array}{l}276( \\
\pm 63\end{array}$ & 63) & $\begin{array}{l}277(92) \\
\pm 29\end{array}$ & $\begin{array}{l}248(95) \\
\pm 24\end{array}$ & $\begin{array}{l}263(63) \\
\pm 28\end{array}$ \\
\hline & $\begin{array}{l}45 \text { or } \\
\text { over }\end{array}$ & $\begin{array}{l}264(36) \\
\pm 28\end{array}$ & $\begin{array}{l}269( \\
\pm 26\end{array}$ & 18) & $\begin{array}{l}291(108) \\
\pm 34\end{array}$ & $\begin{array}{l}257(35) \\
\pm 24\end{array}$ & $\begin{array}{l}257(14) \\
\pm 28\end{array}$ \\
\hline $\begin{array}{c}\text { S-C } \\
\text { Interval } \\
\text { (msec) }\end{array}$ & Al1 Age & $\begin{aligned} & 72(105) \\
\pm & 13\end{aligned}$ & $\begin{aligned} & 77( \\
\pm & 16\end{aligned}$ & 83) & $\begin{array}{l}74(205) \\
\pm 13\end{array}$ & $\begin{array}{l}69(236) \\
\pm 13\end{array}$ & $\begin{array}{l}72(132) \\
\pm 13\end{array}$ \\
\hline $\begin{array}{c}M \\
\text { Value }\end{array}$ & A11 Age & $\begin{aligned} & 8.8(105) \\
\pm & 4.8\end{aligned}$ & $\begin{array}{r}6.0( \\
\pm 4.6\end{array}$ & $83)$ & $\begin{aligned} & 4.0(205) \\
\pm & 5.0\end{aligned}$ & $\begin{aligned} & 4.6(236) \\
\pm & 2.7\end{aligned}$ & $\begin{aligned} & 4.4(132) \\
\pm & 2.6\end{aligned}$ \\
\hline
\end{tabular}

* Numbers in parenthesis indicates the number of cases.

Table 3. Frequency Distribution of the Subjects with Abnormal ATR Value in Group I (Operators:Spraying Pesticides), Group II (Farmers:Non-Operators) and Healthy Controls.

\begin{tabular}{|c|c|c|c|c|c|c|}
\hline \multirow[b]{2}{*}{ No. of } & \multirow[b]{2}{*}{ Subjects } & \multirow{2}{*}{$\begin{array}{c}\text { Group } \\
\text { I } \\
\text { Ma1e } \\
115\end{array}$} & \multicolumn{2}{|c|}{$\underset{\text { I I }}{\text { Group }}$} & \multicolumn{2}{|c|}{$\begin{array}{l}\text { Healthy } \\
\text { Controls }\end{array}$} \\
\hline & & & $\begin{array}{c}\text { Male } \\
39\end{array}$ & $\begin{array}{c}\text { Female } \\
220\end{array}$ & $\begin{array}{r}\text { Male } \\
259\end{array}$ & $\begin{array}{c}\text { Female } \\
150\end{array}$ \\
\hline$S-D$ & Prolonged & $21.7 \%$ & $25.6 \%$ & $28.2 \%$ & $12.0 \%$ & $23.3 \%$ \\
\hline Interval & Shortened & 8.7 & 2.6 & 7.7 & 22.0 & 10.7 \\
\hline S-C & Prolonged & 11.3 & 20.5 & 16.8 & 9.6 & 10.7 \\
\hline Interval & Shortened & 1.7 & 2.6 & 4.6 & 12.4 & 10.0 \\
\hline$M$ & Increased & $53.0^{*}$ & 33.3 & 20.0 & 12.0 & 11.3 \\
\hline Value & Decreased & $3.5^{*}$ & 12.8 & 22.7 & 15.8 & 18.0 \\
\hline Areflexia & & 8.7 & 2.6 & 6.8 & 8.9 & 12.0 \\
\hline
\end{tabular}

\section{* Significantry different}

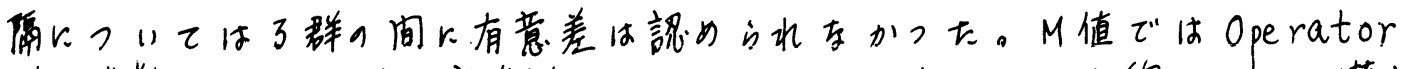

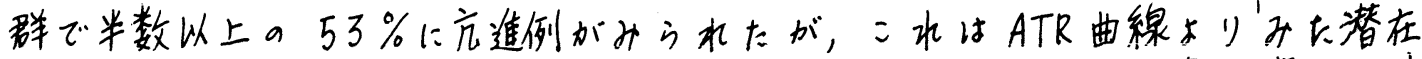
的腱反射方進例が多かったことを示てている。このよう索像が震䒬を使

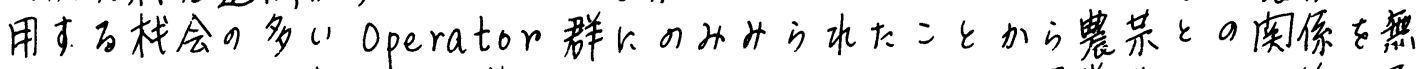
視することが出来ないと考えら水るので、こ北的ATR異常者の并の後の圣

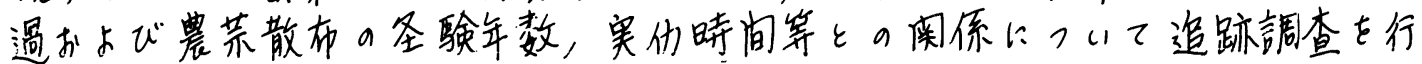
夺う予定である。

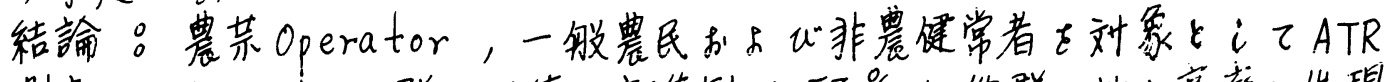

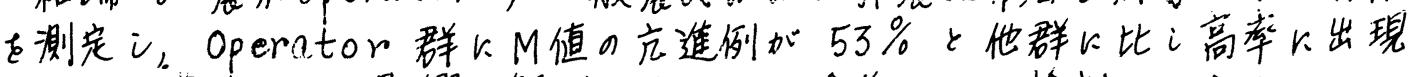

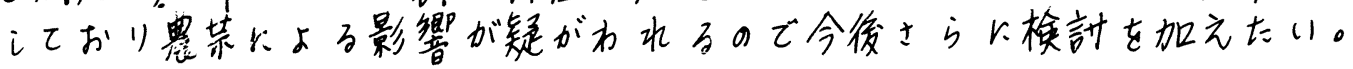


320. 不儎布製防除衣について

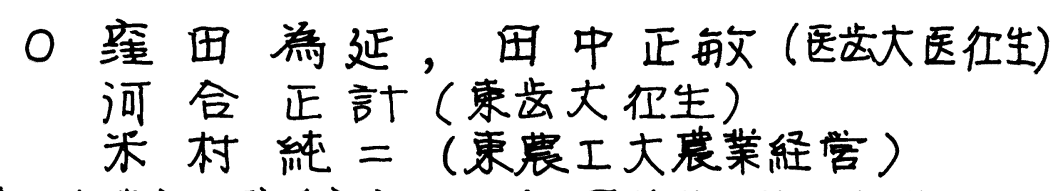
目的：曹莱防除用作業衣(防除衣) は、光の目的から殊々な特性が要 求されるが、高温多湿下で衣服に要請される特性の多くは、これら特性と 排反する。我々はこれら相反する特性を或程度消足されるものといて，経 浲性，栈能性の高いと思われる不践布を用い防除衣を試作した。本研究は この不織布性防除衣の物理的特性，着用時の温热生理的特性を実䓉的に求 め、これの有用性を検討した。

方法：温热負荷は、気温 $32 \pm 1^{\circ} \mathrm{C}$, 湿度 $70 \pm 10 \%$, 文流 $30 \mathrm{~cm} / \mathrm{sec}$ と 。 作業負荷はトレッドミ儿步行 $4 \mathrm{~km} / \mathrm{hr}$ (RMR: 2.0 ) で、安静 $40 \mathrm{~min}$ ，步行 $30 \mathrm{~min}$, 回復 30 分を 1 実曋单位とし. 合計 12 实験を行った。

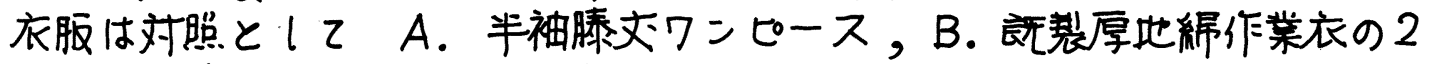
㮔を、防除衣とＩZC．不織布性，D. 市骐ビニー儿製レーニコートの

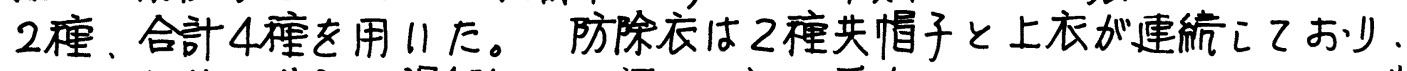
手首，足首，首部は閉頳的で、䫓の一部が露出されているのみである。勒 は白色连動新で, 鞀下は用いなかった。

测定項目は，各部温度、体重、局所発汗量，胍拍、血压、㴜热感等である。

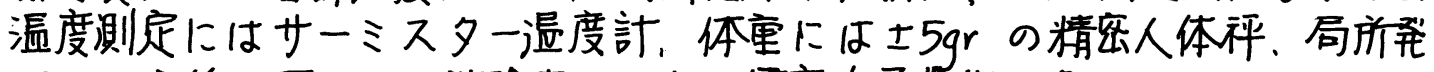
汗には沪紙を用いた。被験看は2才の庭康女子学生3名である。

結果: 衣服材料といて不躘布は厚さ，平面重，比重にすぐれ，また通 武性。耐水生は防除衣とにてビニールに次ぐ。（整い，防除的）一表1一

皮虚温：体幹部と末端部との差は少ない。図1の如く，安静时には呅

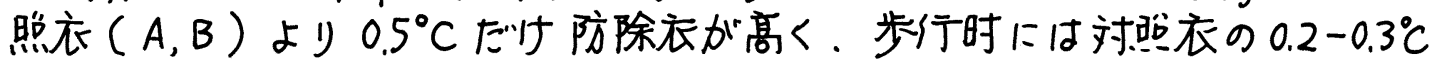
上异に对し，防除衣は $0.8^{\circ} \mathrm{C}$ の上㫒で、回得もお方かった。作業时におけ

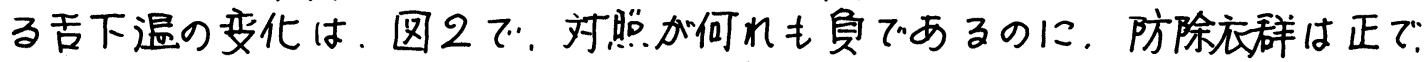
CはDより变化が少ない。平均体温の变化も舌下温の場合と同椂であつた。

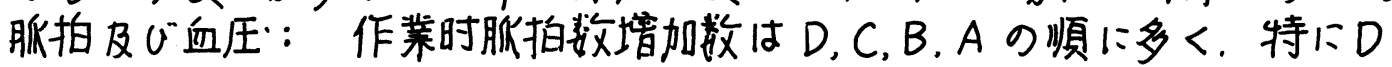
では 130/min に连し $A, B$ の $103 / \mathrm{min}$ に対し差が著るしい。血压の作莱时 变化も胍拍に渠で、DとA，B，C9间に有意差がみられる。

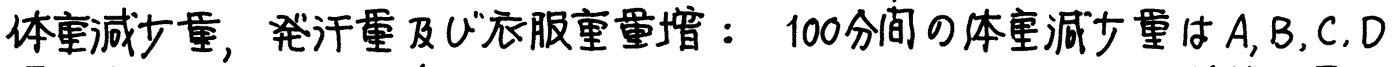
の順に多くなり夫マ平均 $230 \mathrm{gr} ， 290 \mathrm{gr} ， 295 \mathrm{gr} ， 350 \mathrm{gr}$ で, 局所并汗量及

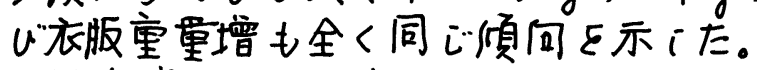

暑热感及し不快威：両看ともABCD順に強くなりDの值は他と有意 差が外られた（国3） 
表1

\begin{tabular}{|c|c|c|c|c|c|}
\hline & $\begin{array}{l}\text { 厚 さ } \\
\mathrm{mm}\end{array}$ & $\begin{array}{l}\text { 平面重 } \\
\mathrm{mg} / \mathrm{cm}\end{array}$ & $\begin{array}{l}\text { 比重 } \\
\mathrm{g} / \mathrm{cm}\end{array}$ & $\begin{array}{c}\text { 通気性 } \\
\mathrm{mI} / \mathrm{cms} \theta \mathrm{c}\end{array}$ & $\begin{array}{l}\text { 耐水圧 } \\
\mathrm{cmH} 0\end{array}$ \\
\hline A ワンピース & 0,27 & 13,2 & 0,48 & 12,1 & 0 \\
\hline B 一般作行衣 & 0,41 & 20,9 & 0,51 & 9,3 & 21 \\
\hline C 不織, 布 衣 & 0,16 & 4,2 & 0,26 & 1,4 & 42 \\
\hline D ヒニニール 衣 & 0,18 & 13,6 & 0,76 & 0 & 100以上 \\
\hline
\end{tabular}
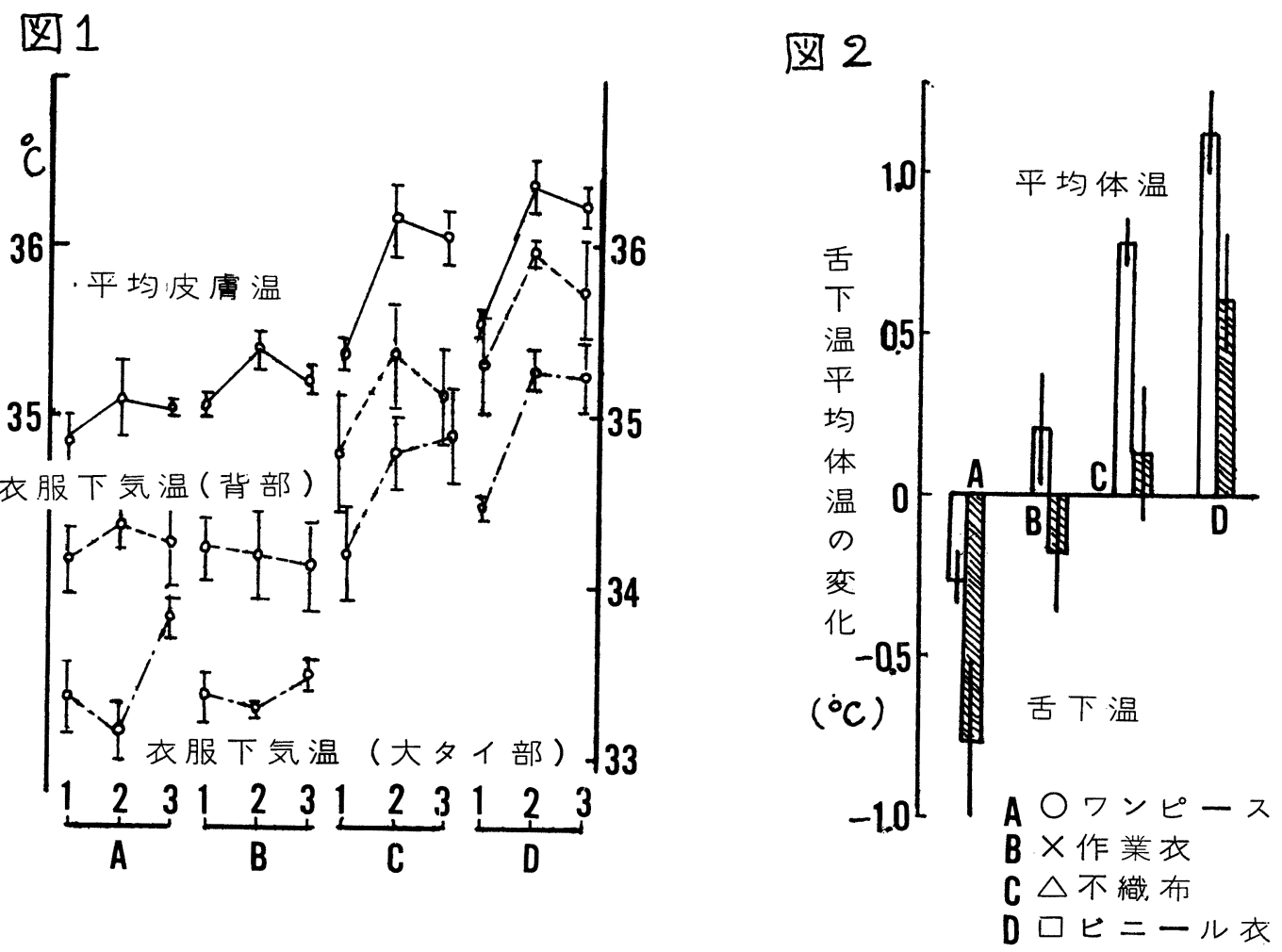

図3

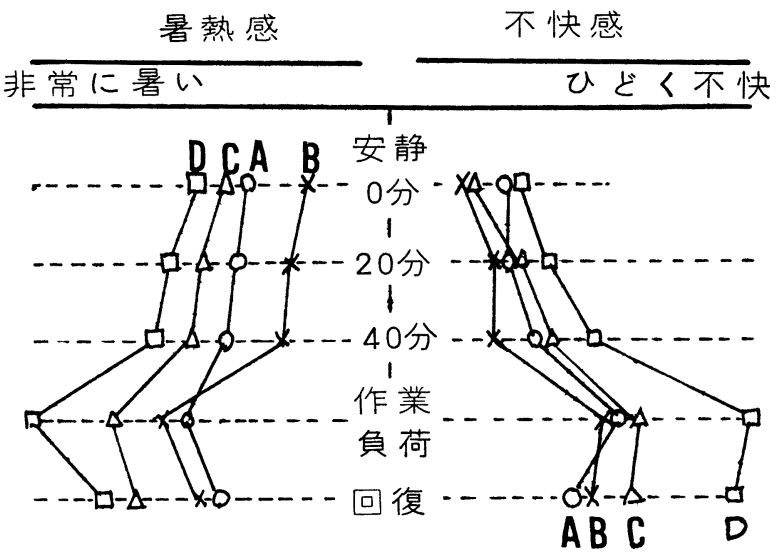

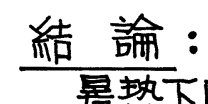

暑热下防除作亲を想定乙。

3名の被倹者について不裁 布梨防除衣の奉用性を検討 [E結果。生理的负担度が 或程度少い，轻い，かなり

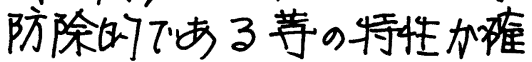
認され，有用であると考之 られる。 


\section{農薬中毒 II}

\section{DithIOCARBAMATE 剂による接触皮慮炎発生に送する}

\section{㕬下敏夫 有松德樹 葍尾利江（熊大．医．公征）}

\section{【目的〕}

Dithiocarbamate 刘およ心゙その荓連物真の接触皮虚炎の態様を实倹的に明 ら加にすること。

[検討項目および方法]

(1) $\mathrm{pH}$ 值 の测定 (10，5，2，0.5\%液を pH-meter にて测定） (2)ラットの 皮下投与による皮下刺敫反太(稀积液 $0.5 \mathrm{ml}$ 皮下注) (3モルモットの

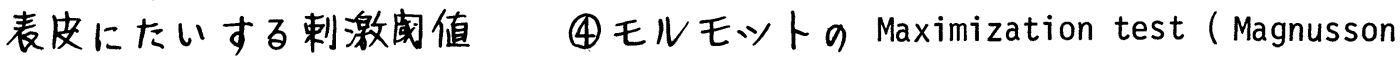
\& Kligman) による威作性の検討

\section{[成瞔]}

(1)表1に示すと同一物傎どおいて，Maneb 8.85-8.44, Manzeb 7.56-7.84, Ethylene thiourea 9.56-9.16, Thiram 6.70-7.80, Dimethyl dithiocarbamic acid

\section{表1、ラットの皮下投与による皮下刺激反応}

\begin{tabular}{|c|c|c|c|}
\hline 物 傎 & 桸釈濃度 & 反 & Thiophanate-methy $\quad 5.50-5.75$ \\
\hline Maneb (manebdi thane ${ }^{(\mathbb{M})}$ & $\begin{array}{lr}x & 2 \\
x & 5 \\
x & 10\end{array}$ & $\begin{array}{c}(++) \\
(++) \\
(+)-(++) \\
\end{array}$ & である。 \\
\hline Manzeb (Zimandithane ${ }^{(\mathbb{B})}$ & $\begin{array}{rr}x & 2 \\
\times & 5 \\
\times & 10 \\
\end{array}$ & $\begin{array}{l}(++) \\
(++) \\
(++) \\
\end{array}$ & 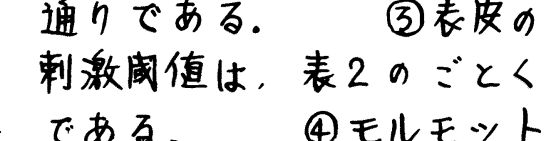 \\
\hline Ethylene thiourea & $\begin{array}{lr}x & 2 \\
x & 5 \\
x & 10\end{array}$ & $\begin{array}{c}(+) \\
(+) \\
( \pm)-(+)\end{array}$ & 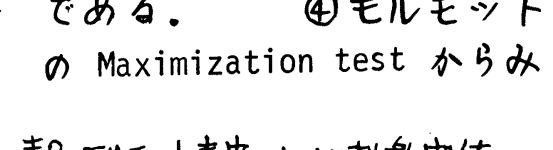 \\
\hline & $\times 2$ & $(++)$ & 敖闻值 \\
\hline Thiram * & $\begin{array}{rr}\times \quad 5 \\
\times 10 \\
\end{array}$ & $\begin{array}{l}(++) \\
(++) \\
\end{array}$ & 物盾 \\
\hline $\begin{array}{l}\text { Dimethyldithiocarbamic } \\
\text { acid sodium salt }\end{array}$ & $\begin{array}{lr}x & 2 \\
x & 5 \\
x & 10\end{array}$ & $\begin{array}{c}(++)-(+++) \\
(++) \\
(+)-(++)\end{array}$ & $\begin{array}{l}\text { Maneb (Manebdithane }{ }^{(\mathbb{B}} M \text { ) } \\
\text { Manzeb (Zimandithane }{ }^{(\mathbb{B})}\end{array}$ \\
\hline $\begin{array}{l}\text { Thiophanate-methyl } \\
\left.\text { (Topsin } \mathbb{B}_{M}\right)\end{array}$ & $\begin{array}{lr}x & 2 \\
x & 5 \\
x & 10\end{array}$ & $\begin{array}{l}(+) \\
( \pm)-(+) \\
( \pm)-(+)\end{array}$ & Ethylene thiourea \\
\hline 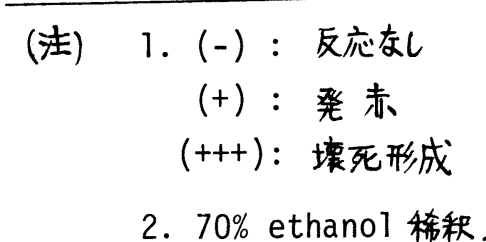 & $\begin{array}{l}( \pm): 7 \\
(++): t\end{array}$ & $\begin{array}{l}\text { 不明瞭原赤 } \\
\text { 著明発赤·浮腄 }\end{array}$ & $\begin{array}{ll}\text { Dimethyl dithiocarbamic } & 10 \% \text { 以上 } \\
\text { acid sodium salt } & \\
\text { Thiophanate-methyl } & 10 \% \text { 以上 } \\
\text { (Topsin } & \end{array}$ \\
\hline
\end{tabular}


表了。モルモットの MAXIMIZATION TEST からみた感作性

\begin{tabular}{|c|c|c|c|c|c|}
\hline \multicolumn{3}{|c|}{ Induction } & \multicolumn{2}{|l|}{ Challenge } & \multirow{2}{*}{$\begin{array}{l}\text { Allergeni- } \\
\text { city }\end{array}$} \\
\hline 物 & 皮内擞度 & 涂布铸度 & 物 & 涂布涶度 & \\
\hline \multirow{2}{*}{$\begin{array}{l}\text { Maneb } \\
\text { (Manebdithane } \mathbb{B}_{M} \text { ) }\end{array}$} & \multirow[t]{2}{*}{$\%$} & \multirow{2}{*}{$\begin{array}{r}\% \\
25\end{array}$} & Maneb & $2^{\%}$ & $\begin{array}{ll}V & (100) \\
V \quad(100)\end{array}$ \\
\hline & & & Thiophanate-methyl & $\begin{array}{l}2 \\
1 \\
\end{array}$ & $\begin{array}{l}\text { III }(30) \\
\text { III }(20) \\
\end{array}$ \\
\hline \multirow{2}{*}{$\begin{array}{l}\text { Maneb } \\
\text { (Manebdithane } \mathbb{B}_{M} \text { ) }\end{array}$} & \multirow[b]{2}{*}{5} & \multirow[b]{2}{*}{25} & Maneb & $\begin{array}{l}2 \\
0.5\end{array}$ & $\begin{array}{ll}V & (100) \\
V & (100)\end{array}$ \\
\hline & & & Thiram* & $\begin{array}{l}2 \\
0.5\end{array}$ & $\begin{array}{l}\text { III }\left(\begin{array}{l}50) \\
\text { II }\end{array}(20)\right.\end{array}$ \\
\hline \multirow{2}{*}{$\begin{array}{l}\text { Manzeb } \\
\text { (Zimandithane }{ }^{\circledR} \text { ) }\end{array}$} & \multirow[b]{2}{*}{5} & \multirow[b]{2}{*}{25} & Manzeb & $\begin{array}{l}2 \\
0.5\end{array}$ & $\begin{array}{ll}V & (100) \\
V & (100)\end{array}$ \\
\hline & & & Thiram* & $\begin{array}{l}2 \\
0.5\end{array}$ & $\begin{array}{l}\text { III }(60) \\
\text { III }(30)\end{array}$ \\
\hline \multirow[b]{2}{*}{ Ethylene thiourea } & \multirow[b]{2}{*}{5} & \multirow[b]{2}{*}{25} & Ethylene thiourea & $\begin{array}{l}2 \\
0.5\end{array}$ & $\begin{array}{ll}\text { IV } & (70) \\
\text { II } & (10)\end{array}$ \\
\hline & & & Thiram* & $\begin{array}{l}2 \\
0.5\end{array}$ & $\begin{array}{rr}\text { II } & \left(\begin{array}{r}20 \\
\text { I }\end{array}\right. \\
\end{array}$ \\
\hline \multirow[b]{2}{*}{ Thiram* } & \multirow[b]{2}{*}{10} & \multirow[b]{2}{*}{25} & Thiram* & $\begin{array}{l}2 \\
0.5\end{array}$ & $\left.\begin{array}{ll}I & (10) \\
I & (10\end{array}\right)$ \\
\hline & & & Maneb & $\begin{array}{l}2 \\
0.5 \\
\end{array}$ & $\left.\begin{array}{cc}\text { III } & \left(\begin{array}{r}40 \\
\text { I }\end{array}\right. \\
0\end{array}\right)$ \\
\hline \multirow{2}{*}{$\begin{array}{l}\text { Dimethyl dithio- } \\
\text { carbamic acid }\end{array}$} & \multirow[b]{2}{*}{10} & \multirow[b]{2}{*}{25} & $\begin{array}{l}\text { Dimethyl dithiocar- } \\
\text { bamic acid }\end{array}$ & $\begin{array}{l}2 \\
0.5 \\
\end{array}$ & $\begin{array}{rr}\text { II } & \left(\begin{array}{r}20 \\
\text { I }\end{array}\right. \\
\end{array}$ \\
\hline & & & Maneb & $\begin{array}{l}2 \\
0.5\end{array}$ & $\left.\begin{array}{lll}I & ( & 0 \\
\mathrm{I} & ( & 0\end{array}\right)$ \\
\hline \multirow{2}{*}{$\begin{array}{l}\text { Thiophanate- } \\
\left.\text { methyl (Tops in } \mathbb{B}_{M}\right)\end{array}$} & \multirow[b]{2}{*}{5} & \multirow[b]{2}{*}{25} & Thiophanate-methyl & $\begin{array}{l}2 \\
1\end{array}$ & $\begin{array}{c}\operatorname{III} \\
\operatorname{I}\left(\begin{array}{r}30 \\
0\end{array}\right)\end{array}$ \\
\hline & & & Maneb & $\begin{array}{l}2 \\
1\end{array}$ & $\begin{array}{l}\text { IV }(70) \\
\text { III }(40)\end{array}$ \\
\hline
\end{tabular}

（注）1.AllergenicityはGradeで。また( 内は感作された動物の頻度を示す。

2. *：70\% ethanol稀釈。他は絍水稀种に上る。

た威作性の検討は，表ろのごとくである。Manebおよび Manzeb刘では，明 らかに強い威作性がうかがわ扎る。また，他の㒺連物傎等との间に，交 差反忘が示唆される。

[まとめ]

Maneb, Manzeb 夺どDithiocarbamate 系榓薬による接触皮膚炎については， とくに感作性を考虑に入水る必要がある。また。威連物盾などとの间の 交差反忘にも注意が旰要である。 


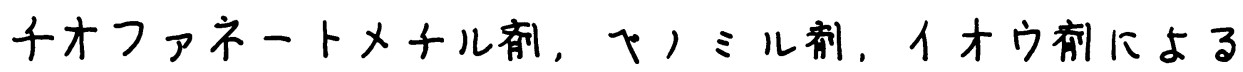
皮膚障害につりて

野村 茂。松下敏夫。上田原。冝尾利江 三角顺一。有㭕德榯（熊大・医・公径生）

1。はどめに

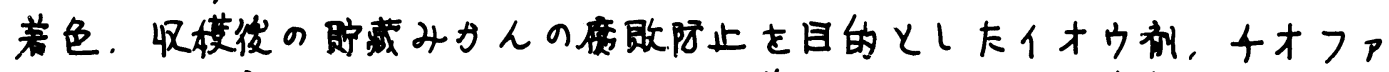

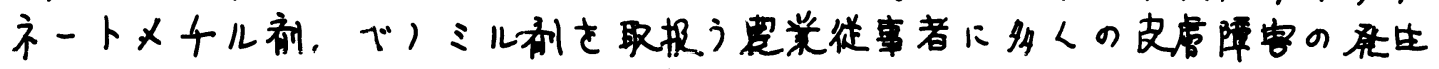

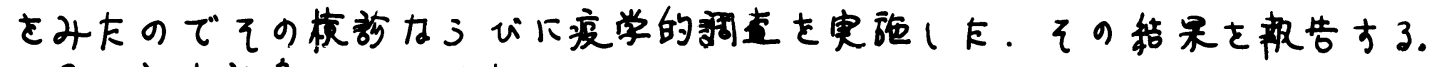

2。炀查対象むよび肃查方法

熊本澋下のみが主座地である河内地区下おりてチオファネートメチル 前を使用した160名およい゙水俣地区におりてべ)ミ儿刺を便用し太294 名

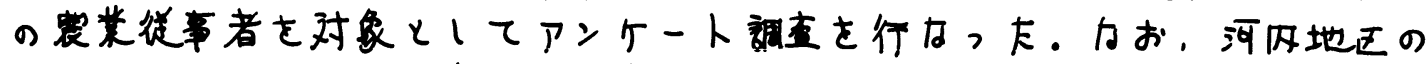

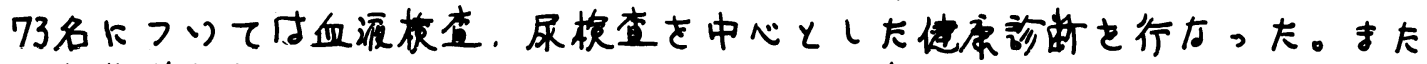

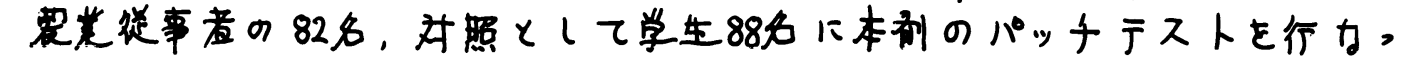

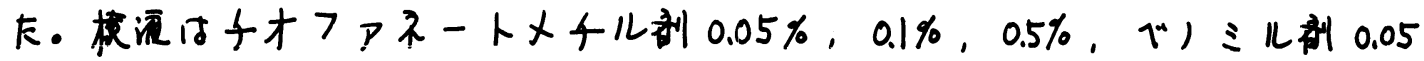

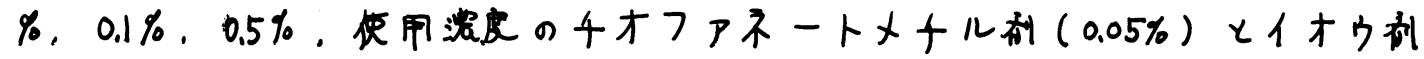

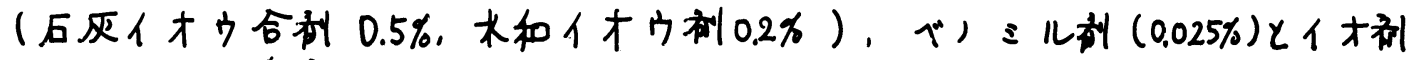

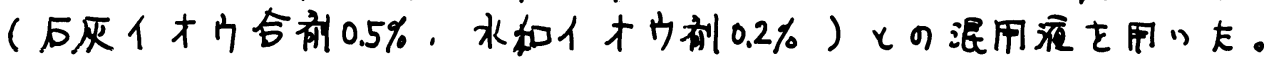

3.結果およய゙考察

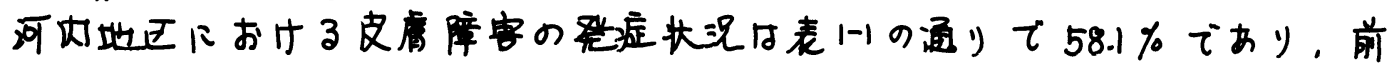

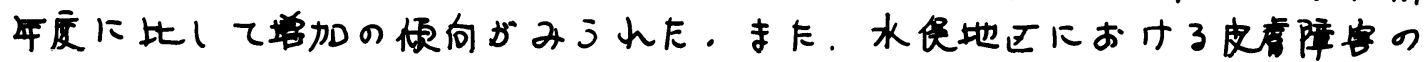

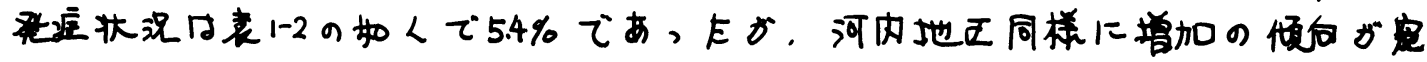

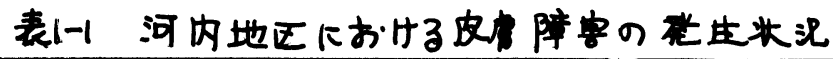

\begin{tabular}{|c|c|c|c|c|c|c|}
\hline & \multicolumn{2}{|r|}{ 勇 } & \multicolumn{2}{|c|}{ \# } & \multicolumn{2}{|c|}{ के } \\
\hline & 挛症者数 & 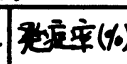 & 症者教 & 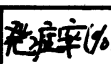 & 胱㾏者 & 矢症率(6) \\
\hline 5.47 年 & 27 & 30.3 & 25 & 32,2 & 52 & 32.7 \\
\hline 484 & 43 & 48.3 & 40 & 56.3 & 83 & 52.2 \\
\hline 494 & 47 & 52.8 & 46 & 64.8 & 92 & 58.1 \\
\hline
\end{tabular}

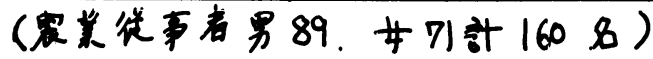

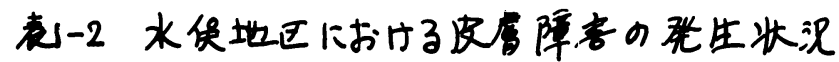

\begin{tabular}{|c|c|c|c|c|c|c|}
\hline & \multicolumn{2}{|c|}{ 曺 } & \multicolumn{2}{|c|}{ \# } & \multicolumn{2}{|c|}{ 핳 } \\
\hline & 魏应者数 & 动症率 $\left(y_{0}\right)$ & 晒底者效 & 致症㾕 $\left(x_{0}\right)$ & 社若数 & 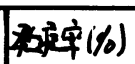 \\
\hline S.47年 & 1 & 0.6 & 2 & 1.6 & 3 & 1.0 \\
\hline 48 年 & 3 & 1.8 & 4 & 3.3 & 7 & 2.4 \\
\hline 49 年 & 4 & 2.3 & 12 & 9.8 & 16 & 5.4 \\
\hline
\end{tabular}

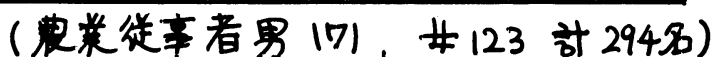

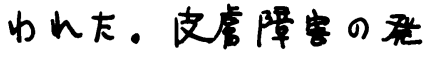
生匹周保があると思わ

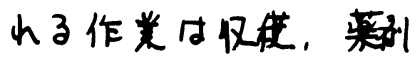
地布、調合口どでおり

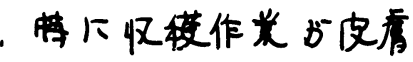
炎存に闹保するよう である。河内地过の皮 障审の原因蘶䘞は4 オファスートメ4ル剂 、水和イオウ削。万灰 イオウ合䘞の3藻副て あるが、これう荣副の 了格方了い口2数湿用 (ているもの下多くな う内子( $82 \%)$. 皮 


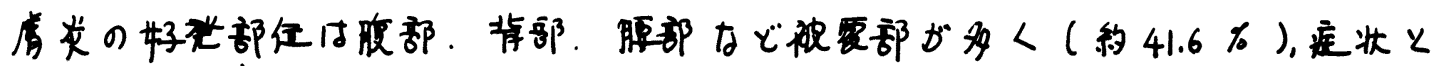

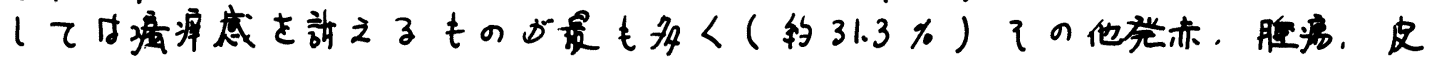

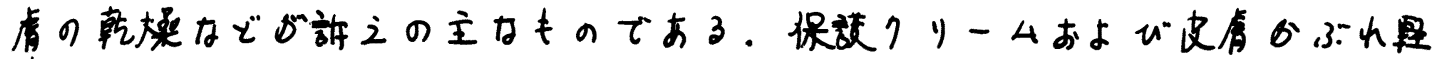

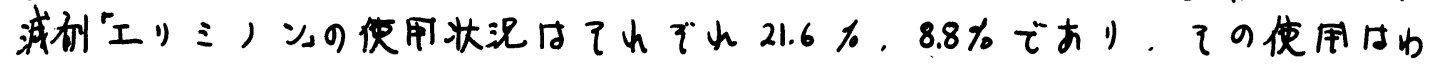

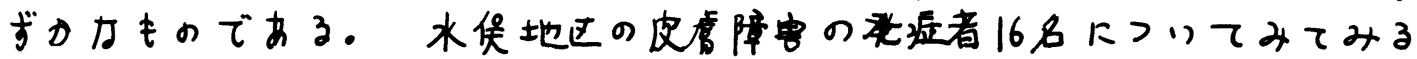

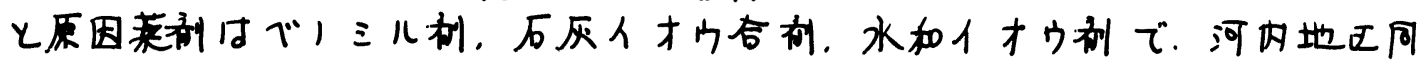

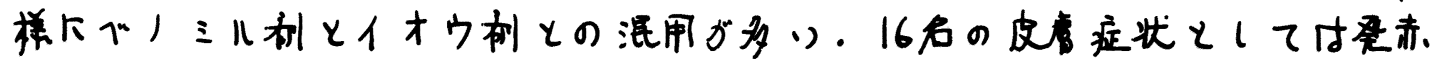

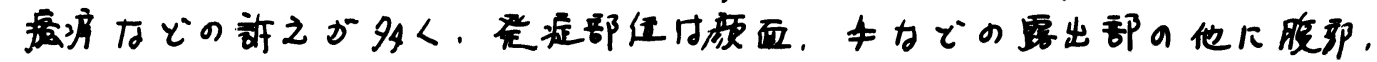
胸部、大腿部などの被要部にもみうれている。

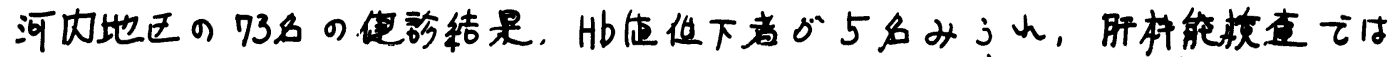

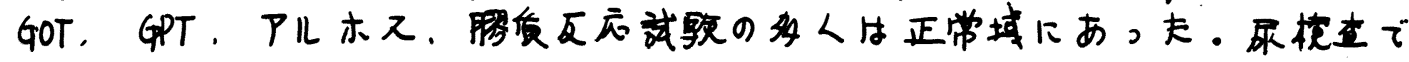

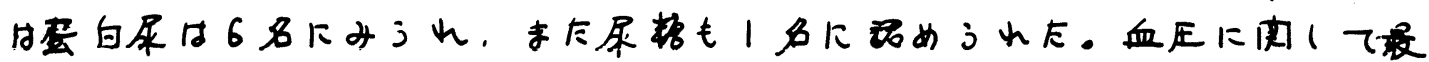

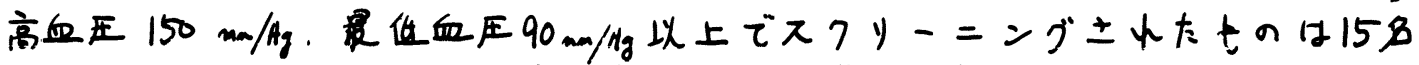

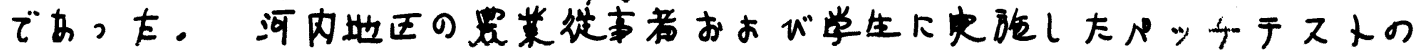

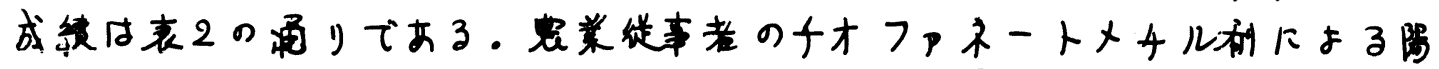

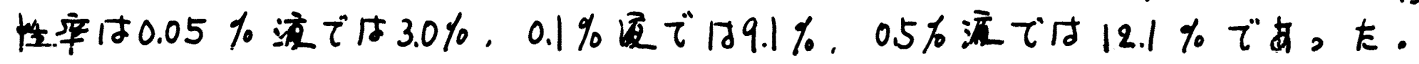

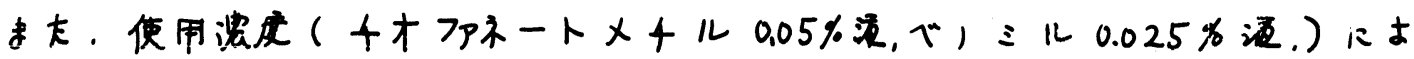

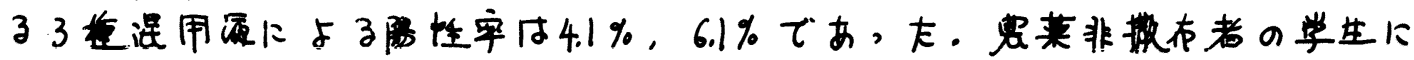

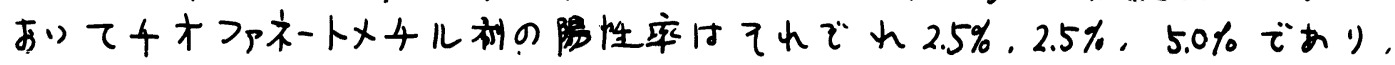

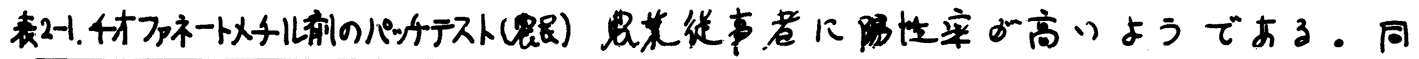

\begin{tabular}{|r|r|r|c|}
\hline & $0.05 \%$ & $0.1 \%$ & $0.5 \%$ \\
\hline- & $30(90.9)$ & $24(66.7)$ & $21(63.6)$ \\
\pm & $2(6.1)$ & $6(18.2)$ & $8(24.3)$ \\
\pm & $1(3.0)$ & $3(9.1)$ & $4(12.1)$ \\
\hline
\end{tabular}

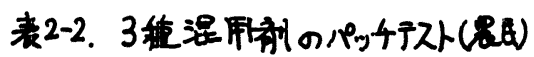

\begin{tabular}{|c|c|c|}
\hline & 後 & ר゙! \\
\hline- & $41(83.7)$ & $39(79.6)$ \\
\hline \pm & $6(12,2)$ & $7(14,3)$ \\
\hline$t$ & $2(4.1)$ & $3(6.1)$ \\
\hline
\end{tabular}

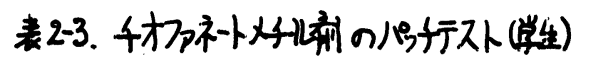

\begin{tabular}{|c|c|c|c|}
\hline & $0.05 \%$ & $0.1 \%$ & $0.5 \%$ \\
\hline- & $38(95.0)$ & $36(90.0)$ & $36(90.0)$ \\
\pm & $1(2.5)$ & $3(7.5)$ & $2(5.0)$ \\
+ & $1(2.5)$ & $1(2.5)$ & $2(5.0)$ \\
\hline
\end{tabular}

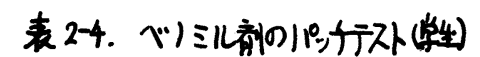

\begin{tabular}{|c|c|c|c|}
\hline & $0.05 \%$ & $0.1 \%$ & $0.5 \%$ \\
\hline- & $45(93.7)$ & $43(89.6)$ & $39(81.2)$ \\
$t$ & $1(2.1)$ & $4(8.3)$ & $6(12.5)$ \\
$t$ & $2(4.2)$ & $1(2.1)$ & $3(6.3)$ \\
\hline
\end{tabular}

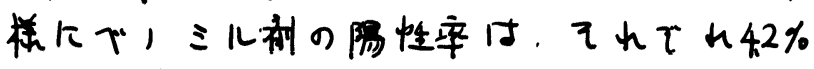
. $2.1 \%, 6.3 \% て ゙$ め。.十オファネートメ

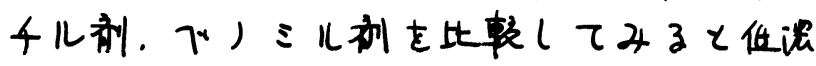
度，高虫度ともにベノミ儿利の淂性率か高 りようであるあ，有意の羑けない。

4. 钴部

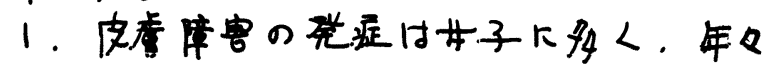
弟加の倾向ず窟いれる。

2. ペッナテストおりてチオファネート

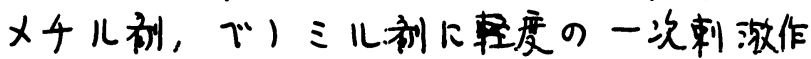

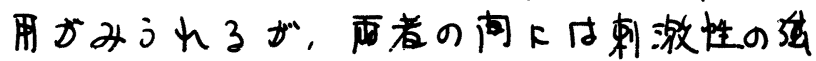
さの有熏の善はなり

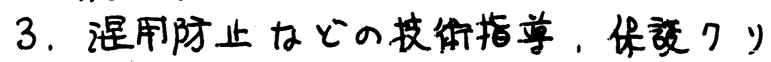

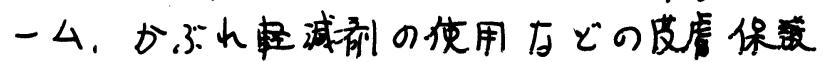

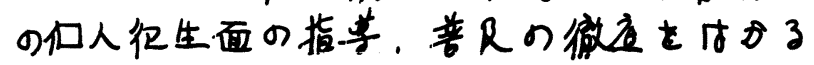
必要がある。 
農薬にする皮虍炎に对するパッチテストの調查研究 ( 第 3 報)

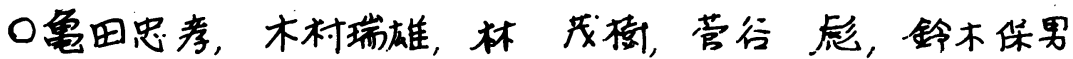 黑川誠悦}

（秋田県・平虎讼合病院・農村医学研究所）

調查对象および方法

秋田具平婏郡の果樹と稻作を主とする 地域の婦人35人に，当地で繁用されてい る農薬8種(スミ4オン，ダイアジ）ン， 多イセン，モ)ックス，グラモキンン， 二ップ，名人ホルタン，ブラエス，よ く使われている農楽川種(デス エルサ ンアカール，ケルセン：トリアジン， ダコニール，マンネブダイセン，トレフ アノサイド，ベンレート、トップジン， MO)の計19種を用い貼布試験を行かっ た。試薬濃度娒繁用されている8種につ いては，その使用濃度を中心に。その $1 / 10$ 倍、10倍の3段階を，むく用いられる॥ 種については，その使用濃度で使用した。 試薬をテストプラスター（バイエルド ルフ社) に滴下し，両側背部に貼布し， 48時間目に剥脱，硯察した。判定方法は 野村の法に従った。これらの検查は昭和 50年3月に行なわれた。

\section{結果}

パッチテストの結果は表|のごとくで おった。表中「判定不能」とは観察時に 貼布片が脱落していたもので7件 ( $5.8 \%)$ にみられた。環状紅斑とは，試料貼布片 の辺縁部の紅斑で，大体一次的刺激反应 と考えられる、この桹な例が陽性で9例， 疑陽性でて例みられた。使用濃度以下で 14例みられた事出，使用摆度でも、個人 によっては刺激物として作用する事を示 していると思けれる。

問題は徒来の考えとは逆に，使用淟度

表|

\begin{tabular}{|c|c|c|c|c|c|c|}
\hline & & \pm 1 & $\pm 1+$ & H & H & 判定不能 \\
\hline $\bar{F} \quad \pi$ & 28 & 4 & & & & $3( \pm 1)$ \\
\hline スミチォン & 29 & 1 & $3\left(r^{*}\right)$ & & & $z( \pm 1)$ \\
\hline & 28 & 511 & 1 & & & $1( \pm 1)$ \\
\hline & 29 & 3 & 3 & & & \\
\hline ダイアジン & 17 & 6 & $z$ & & & 10 \\
\hline & 19 & 63 & $3(2)$ & & & $\gamma( \pm 1)$ \\
\hline & 26 & 8.1 & $1\left(P^{3}\right)$ & & & \\
\hline エルサソ & 26 & 61 & 1 & & & $z( \pm 1)$ \\
\hline アカール & 27 & 3 & $z$ & & & $3( \pm 1)$ \\
\hline ケルセン & 20 & 52 & $z\left(r^{2}\right)$ & & & $8( \pm 1)$ \\
\hline トリアッ゙ン & 23 & 8 & 1 & & & $3(+1)$ \\
\hline マンネブダ代り & 29 & $4\left(r^{\infty}\right)$ & 1 & & & 1 \\
\hline ダイ セン & 30 & 5 & & & & \\
\hline & 29 & 5 & 1 & & & \\
\hline & 27 & 7 & 1 & & & \\
\hline モl ※クス & $z 8$ & $400^{*}$ & 1 & & & $z( \pm 1)$ \\
\hline & 30 & 5 & & & & \\
\hline & 33 & $z$ & & & & \\
\hline グラモキンン & 24 & $5(1)$ & & & & $6(+1)$ \\
\hline & 25 & $\left.60^{*}\right)$ & & & & $4( \pm 1)$ \\
\hline & 30 & 1 & 1 & I & & $z$ \\
\hline トレアハサ代 & 30 & 4 & 1 & & & \\
\hline$=\cdots \quad 7^{\circ}$ & 26 & 7 & $\left.z(1)^{*}\right)$ & & & \\
\hline & 26 & $8(1)$ & $1 C^{*} \mid$ & & & \\
\hline & 23 & 6 & 5 & & & $l( \pm 1)$ \\
\hline ダイホルタン & 17 & 9 & 3 & $z$ & & $4( \pm 1)$ \\
\hline & 21 & 9 & 3 & 1 & & 1 \\
\hline & 27 & 5 & 2 & 1 & & \\
\hline ベンレート & 27 & 5 & $z$ & 1 & & \\
\hline トップジン & 16 & $\left.8(1)^{2}\right)$ & 5 & & & 6 \\
\hline ブラ エス & $\begin{array}{l}25 \\
31\end{array}$ & 6 & 2 & 1 & & 1 \\
\hline & $\begin{array}{l}31 \\
25\end{array}$ & $\begin{array}{l}4\left(r^{2}\right) \\
9\left(1^{*}\right)\end{array}$ & 1 & & & \\
\hline$M$ & 27 & 3 & $2\left(r^{2}\right)$ & & & $3( \pm 1)$ \\
\hline ダュニール & 15 & 11 & 6 & 1 & 1 & $1(+1)$ \\
\hline 計 & 893 & $\begin{array}{l}193 \\
67 \times 5)\end{array}$ & $\begin{array}{l}59 \\
(92)\end{array}$ & 8 & 1 & $71\left[\begin{array}{c} \pm 12 \\
+3\end{array}\right]$ \\
\hline
\end{tabular}

注. 我: 靦状兹玟王 
表乙

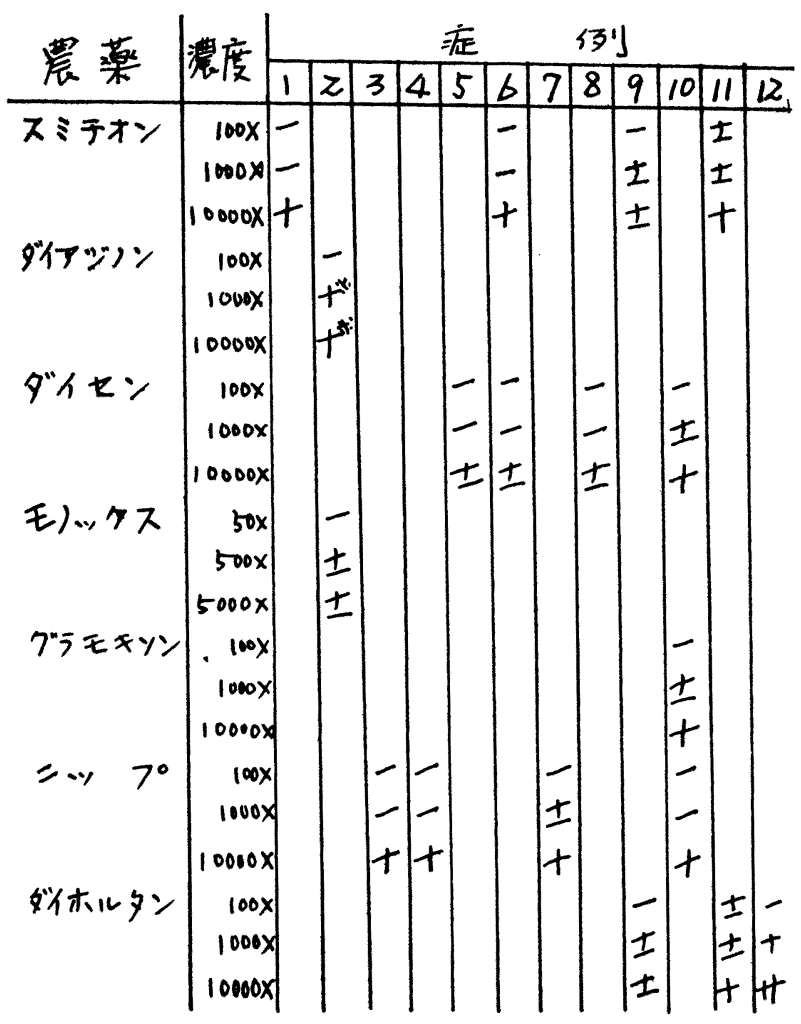

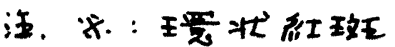

老3

\begin{tabular}{|c|c|c|}
\hline デ & 0 & \\
\hline スミチオン & 5 & 14.3 \\
\hline ダイアン゙ルン & 3 & 8.6 \\
\hline エルオン & I & $z .8$ \\
\hline アカール & $z$ & 5.7 \\
\hline ケルセン & I & 2.8 \\
\hline トリアジン & $z$ & 5.7 \\
\hline ダフ = ル & 9 & 25.7 \\
\hline マンネブダ代ン & 1 & 2.8 \\
\hline ダイセン & $z$ & 57 \\
\hline モゅクス & 0 & \\
\hline グラモキリン & 3 & 8.6 \\
\hline トレママ)サイド & I & 2.8 \\
\hline $\begin{array}{l}=ッ 7^{\circ} \\
\text { ダ椺ルタン }\end{array}$ & $\begin{array}{l}5 \\
8\end{array}$ & $\begin{array}{l}14.3 \\
22.8\end{array}$ \\
\hline $\begin{array}{l}\text { அイホルー } \\
\text { ベンレート }\end{array}$ & $\begin{array}{l}0 \\
3\end{array}$ & $\begin{array}{l}22.8 \\
8.6\end{array}$ \\
\hline トップ ッ゙ン & 5 & 14.3 \\
\hline プラエス & 3 & 8. \\
\hline$M$ & $\begin{array}{c}1 \\
55\end{array}$ & \\
\hline
\end{tabular}

表 4

\begin{tabular}{|c|c|c|c|}
\hline & 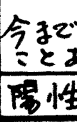 & $\frac{1}{1, \%}$ & 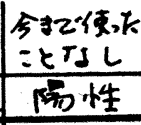 \\
\hline$\overline{7} \quad$ ス & & & \\
\hline スミチオン & $z$ & 19 & 3 \\
\hline ダイアレ゙ンン & $z$ & 5 & 1 \\
\hline エルォン & & 4 & 1 \\
\hline Tカール & 1 & 5 & 1 \\
\hline หルセン & & 6 & I \\
\hline $\begin{array}{l}\text { ドアレ゙ン } \\
S^{\prime} \Xi=-ル 4\end{array}$ & & I & $\begin{array}{l}2 \\
9\end{array}$ \\
\hline ホンネフダイ゚ & & 1 & 1 \\
\hline $\begin{array}{l}\text { ダイ ン } \\
\text { モ)ックス }\end{array}$ & $z$ & $\begin{array}{l}16 \\
14\end{array}$ & \\
\hline グラモキソン & & 1 & 3 \\
\hline ルマフォ代 & & 1 & 1 \\
\hline$=\cdots 7^{\circ}$ & & 3 & 5 \\
\hline ダイホルタン & & 1 & 8 \\
\hline ベンレート & & & 3 \\
\hline トップッ゙ン & & 5 & 5 \\
\hline ブラエス & 1 & 4 & $z$ \\
\hline$M \quad O$ & & 12 & 1 \\
\hline 言十 & 8 & 98 & 47 \\
\hline
\end{tabular}

の兴倍の方が陽性が多かったことである。各 固人によってもこの傾向がうかがりれ，に人 でみられた（表2）。これをどのように考え ればすいのか。原因ははっきり判らず，更に 検討したいと考えている。

各莧刜则する陽性の件数は(1人)件とし た)，表了のごとくである。

これと以前に使用したことのある農薬との 関係は表4のごとくである。 


\section{4。農薬による有栈水銀中毒—ニューメキシコの例}

\section{原田正純（熊大・体質医学研究所）}

1960 年, 1965年にイラフ，1962年に西パキスタン，1964年にグアテマラ など集団的な有栈水銀農菒中毒が報告之れている。日本を旧め各口がす でに有栈水銀農莫を中止にている。しかし, 1972年にはイラクでかってな い規模の中毒が恣生している。一方, 水俣病もる长有栈水銀中毒である。

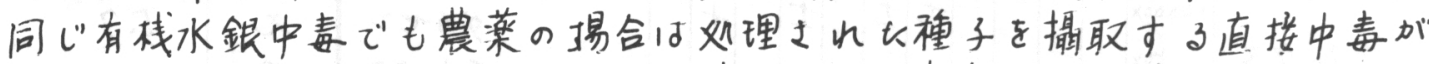

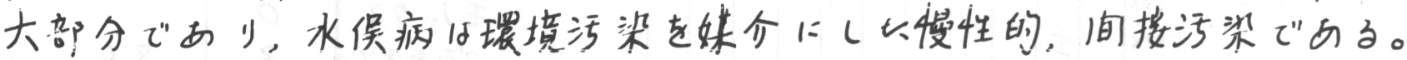

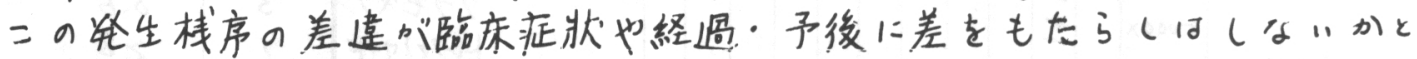

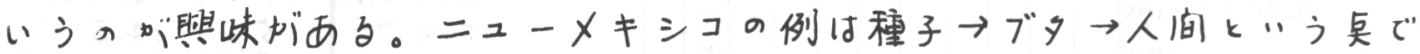

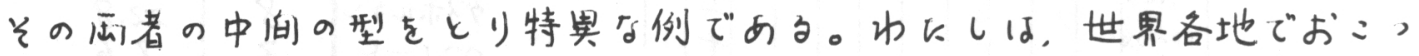
た有栈水銀の比較研突の以め1975年3月12 的15日, ニューメキシコ州アラ

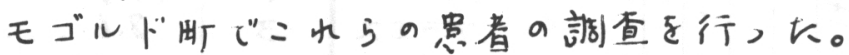

1969 年8月下旬, Zの家9主人はMethylmencury dicyandiamide で观理し

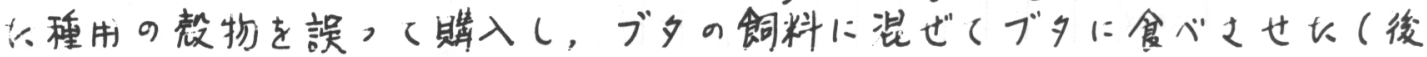

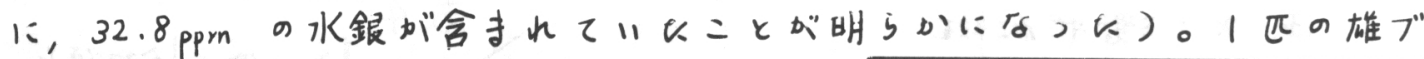

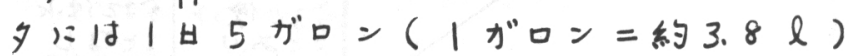
づつ与之长。1か月後の9月下旬にニのブタ

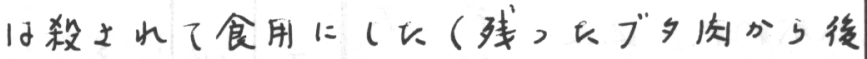

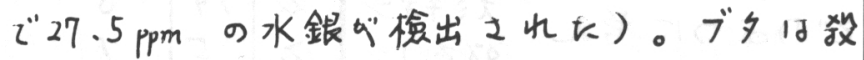

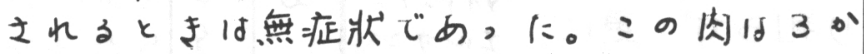
月半, 冷谏しなが方自家消費した。10月中旬 に, 他の仔ブ夕14匹中12 汃麻痤や㾏严々お 二して死に, 2 匹は視打障官残しく生际し ていU。: 銀が㯖出されている。この家族1

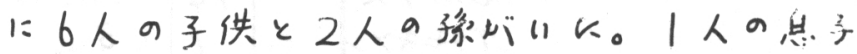

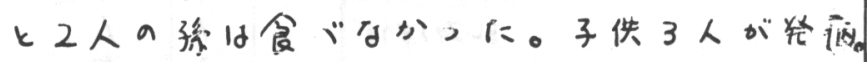

症例 1 : 女性, 1961年8月生れ。

196912 月 4 日, 学校で鉄棒から落5, 側

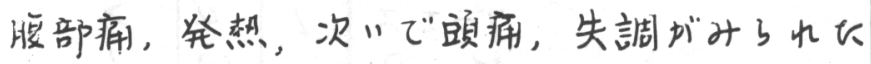
。12月19日にも舆䛽狱熊となり。失調性步行 概音障害が著明となり視力障容が出現。

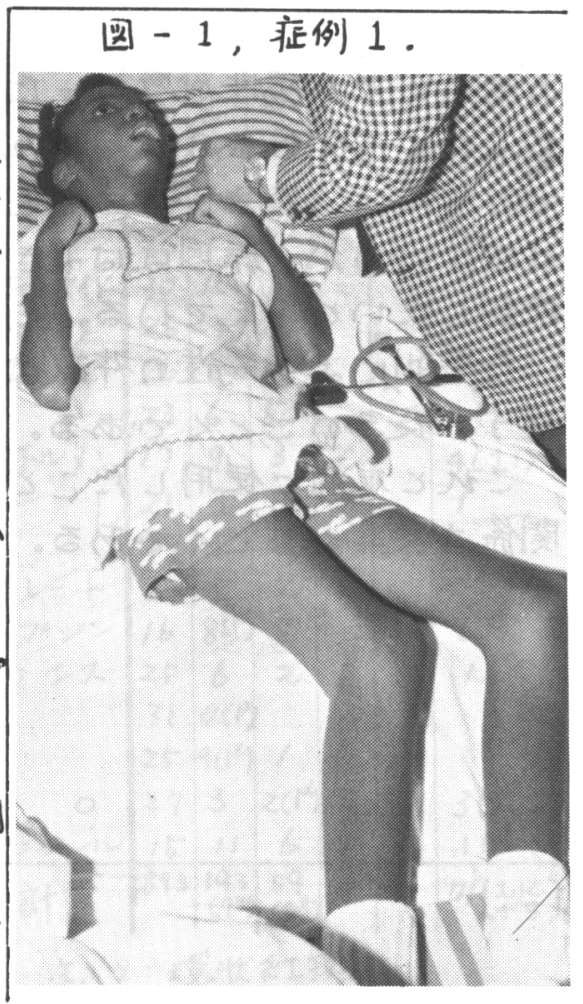


12月23日には立てす”, 食事も介助寺必要とし,12月27日には昏睡狀態, 世

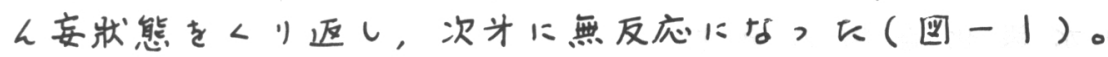

症例 $2: 1956$ 年生九, 男性。

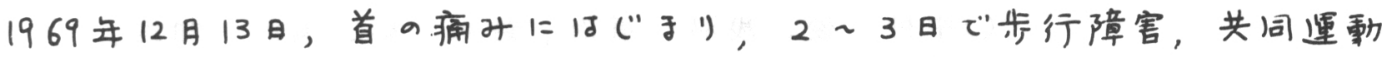

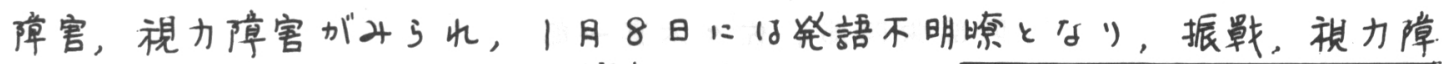

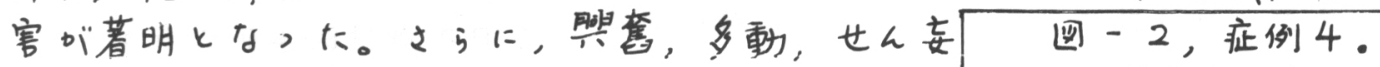
状熊が出现し, 病的反射し内飞主りにる。血中 水銀1d 2,910 ppb, リ」一儿中に3,330 ppb。

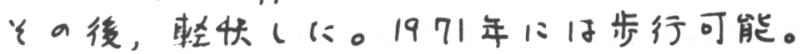

症例 3 ; 女性, 1952年生水。

1969 年12月26日, 步行障官と視力障害が2了れ 1月2日にもうろう状態出現。1月8日には強

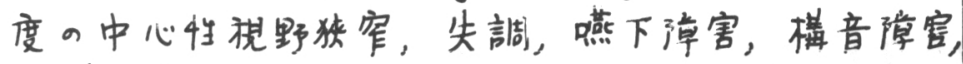

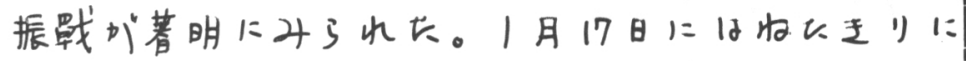
的比。血中水銀は2,780 p p b. 毛酸中 $1=2,436 \mathrm{ppm}$.

症例 4 : 男性, 1970年4月生れ。

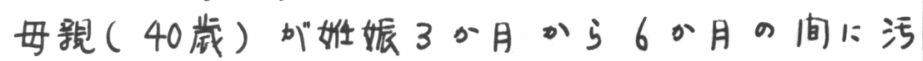

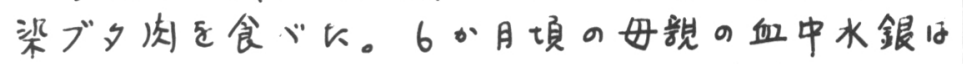

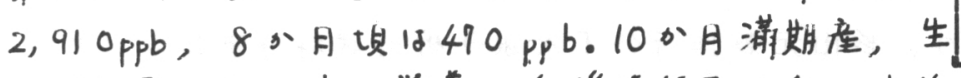
下時作重3 kg, 人工兴泰。分娭時仮死1分。生後

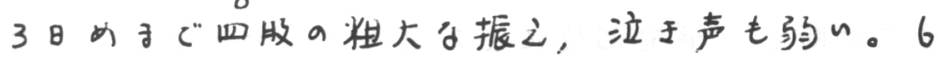

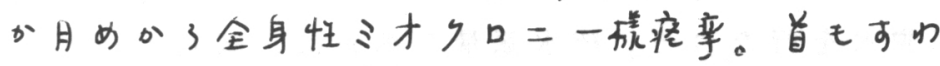

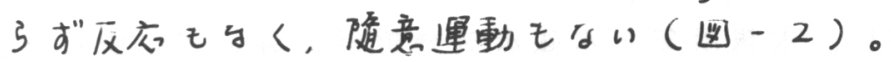
胎紫性(先天性) 有栈水銀中毒火思内几る。

現㾏症狀( 1975 年3月12,13日)

臨床症状的表一1のようにるとめ引长。2 例 はAkinctic mutisina状熊示示。1例改善し

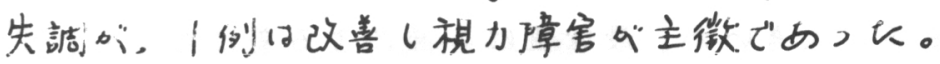

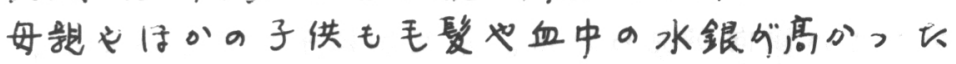

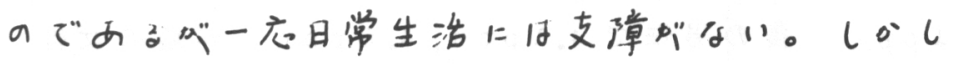
軽い症彇が見落土れている。

水俣飞比較して，初期、急性重症例飞同一であ

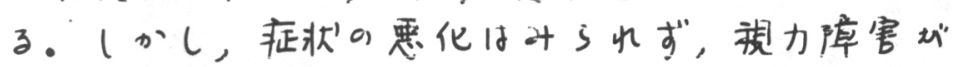
强く, 知的栈能障害や知觉障害虫“改害例では軽い。 脂㸺性全く同じで西る。

1975 年2月にもこの地区でブタの有栈水銀中毒。

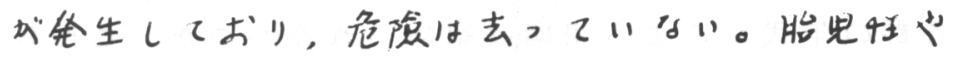
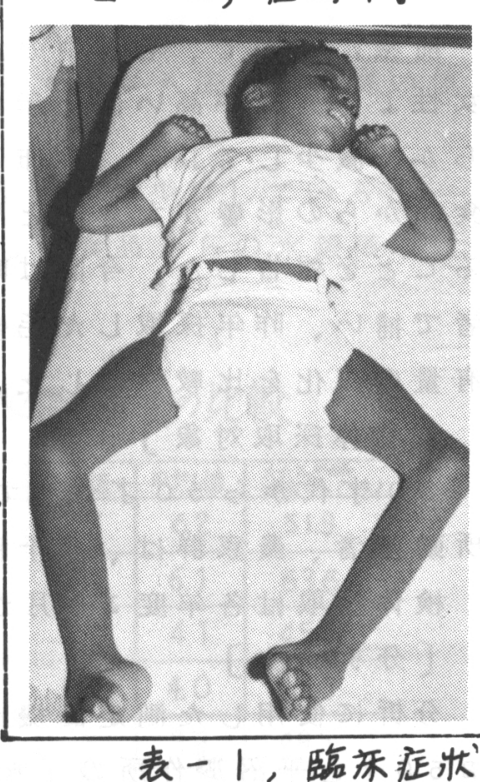

\begin{tabular}{|c|c|}
\hline 症例 & 1234 世 \\
\hline 知営障害 & $? \pm+?+$ \\
\hline 構音障客 & 不十廾不一 \\
\hline 视打愺套 & $H+H \perp H-$ \\
\hline 視野狭窄 & 不不册不十 \\
\hline 眼球振鳘 & $H-+H-$ \\
\hline 失碀步行 & 不 + 卅不一 \\
\hline アジ防゙拉・ゼ & 不十廾不 \\
\hline 指卓試咴 & 不 」， 不一 \\
\hline 振 & 不 $\perp$ 不 \\
\hline 四肢婪形 & $H \perp+m-$ \\
\hline 寡動・多動 & $H-C H-$ \\
\hline 病的反射 & $H-+H-$ \\
\hline 㯖カ愺害 & 不一」不 $\frac{1}{?}$ \\
\hline 百始反射 & $H-\perp H-$ \\
\hline 并作症状 & +--+ \\
\hline 知能障害 & $H+\perp+m+$ \\
\hline
\end{tabular}

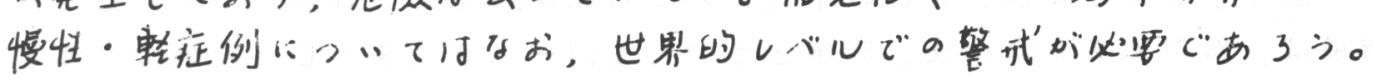


325. 毛聚中水銀化合物の分析

○中村俊、浅沼信治、鈴木彰、黒沢和堆、 阿部栄四郎。佐々木喜一郎

(日本農村医学研究所)

前報に的にて、毛墏中の水銀化合物の分析を行をい。農家群より非農家群が、 女性より男性が高ら值を示し。特に農家群においては、水銀農薬散布当時より明 らかに減少しており、散布により吸収するとんらょうな直接的なすのではなく、 食品からの影響が大的思われ、食品中水銀化合物の分析を行をら必要性があ るととを報告した。今回は昨年と同一人を対象者とし。検体不足分を新しい対象 者で補い、昨年採取した毛髮を今回の分析方法にあわせ分析し、2年間の水銀含 有量の変化を比較検討した。

[検体採取対象]

$30 才$ 才代ら50才代までの男女で。非農家群は、佐久総合病院及び佐久市役 所勤務者、農家群は、八千穂村で農業に従事す万者である。

検体採取は各年度10月から1月まで行なった。

[分析方法]

分析飞使用した測定器機は。杉山元製作所の「水銀分析用試料分解变置 MV 250 」と平溰製作所の「水銀蒸気分析計 HG-1」である。

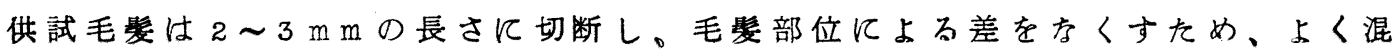
合し、テシケータにて完全に脱水を行なつた。総水銀量の測定は、試料10 mgを 水銀分析用試料分解装置で分解し、水銀蒸気を水銀蒸気分析計に道らて測定した。 らわゆる鉝フマルガム法である。メチル水銀量の測定は前報のとらりである。

[結果]

以上の方法により得られた結果が表1である。最高值は、48年度の・13.0 p pm 49 年度の11.8 ppmであり同一人ではないがいずれる非農の男性である。最低值 は、48 年度の1.0 p pm、49 年度の1.1 ppmとてれも同一人てはないが農の女性 である。最高值は各群による差が大的。゙。最低值は各群による差は認められず 平均值が高い汪ど壮らつきが大をい傾向が見られる。年度別に平均值をみると、 非農の男性て6.2 p pm。6.1 p p m 農の男性で4.1 p pm、4.0 p pm、非農の女性 て $3.9 \mathrm{ppm} 、 3.5 \mathrm{p} \mathrm{pm}$ 、農の女性て $2.3 \mathrm{p} \mathrm{pm、1.9p} \mathrm{pm} \mathrm{と} 2$ 年間と男性より女性 が。非農より農が低い值を示し。メチル水銀含有率は、各群とも49年度の方か 高い割合を示した。

図1は、農、非農、男女別毛髪中水銀含有量である。図2 は、年代別毛髮中水 銀含有量である。非農男性の30才代と農男性の40才代は年度に上る増加が見 られ、他の年代は、各群とも下降している。また各群とも30才代が50才代よ り高い值を示しているが、各群の年代別による相関は認められなかつた。てれら の結果は。新対象者を除いた。昨年とまつたく同一人を対象とした結果ても汪と 
んど同様を傾向を示した。

\section{[考察]}

昨年我々は総水銀の分析を酸素ボンブ法により検体を分解し、還元気化法で測 定を行なつたが、んくつかの欠点があ。今回は多くの検体が簡便に処理で、 屯た理論的により正確を值が得られると思われたのて、前記の金丁マルカム法を 採用した。酸素ボンブ法の標準液添加実験てはュ00\%の回収が得られ、本た、金 アマルカム法で。標準液を処理後、空試験を行をつても水銀は検出されず、損失 はをいものと思われたのが、同一検体での測定值は金アマルガム法の方が高ん值 を示した。その理由については現在検討中でる。

2 年間の変化を比較してみると、48 年度がわずかながら減少はしているが， 非農の男性では相変らず高い值を示しており、依然として食品からの水銀掫取は 続いていると思われる。

食品。とくに我々の主食て ある米につんての分析は。分 表1：二年间の毛髧中水銀含有量の比較 析方法に上る差や。ハラッキ が大く。現在検討中である。

今後毛髪中の水銀含有量 の分析は行なつていく必要か ある。

\begin{tabular}{|c|c|c|c|c|c|c|c|}
\hline & & 年度 & 湌体数 & 筑骨值 & 值低 & 平均值 & 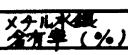 \\
\hline \multirow{4}{*}{ 男 } & \multirow{2}{*}{$\begin{array}{l}\text { 非 } \\
\text { 鹿 }\end{array}$} & 48 & 26 & 13.0 & 2.8 & 6.2 & 51.9 \\
\hline & & 49 & 26 & 11.8 & 3.1 & 6.1 & 63.6 \\
\hline & \multirow{2}{*}{ 㻃 } & 48 & 21 & 7.1 & 2.1 & 4.1 & 45.9 \\
\hline & & 49 & 26 & 7.2 & 2.0 & 4.0 & 68.0 \\
\hline \multirow{4}{*}{ 女 } & \multirow{2}{*}{$\begin{array}{l}\text { 非 } \\
\text { 晨 }\end{array}$} & 48 & 27 & 6.6 & 1.9 & 3.9 & 49.5 \\
\hline & & 49 & 14 & 6.4 & 2.0 & 3.5 & 58.5 \\
\hline & \multirow{2}{*}{ 農 } & 48 & 25 & 4.0 & 1.0 & 2.3 & 36.1 \\
\hline & & 49 & 19 & 3.2 & 1.1 & 1.9 & 43.6 \\
\hline
\end{tabular}

\section{因1. 農·非農, 男女別}

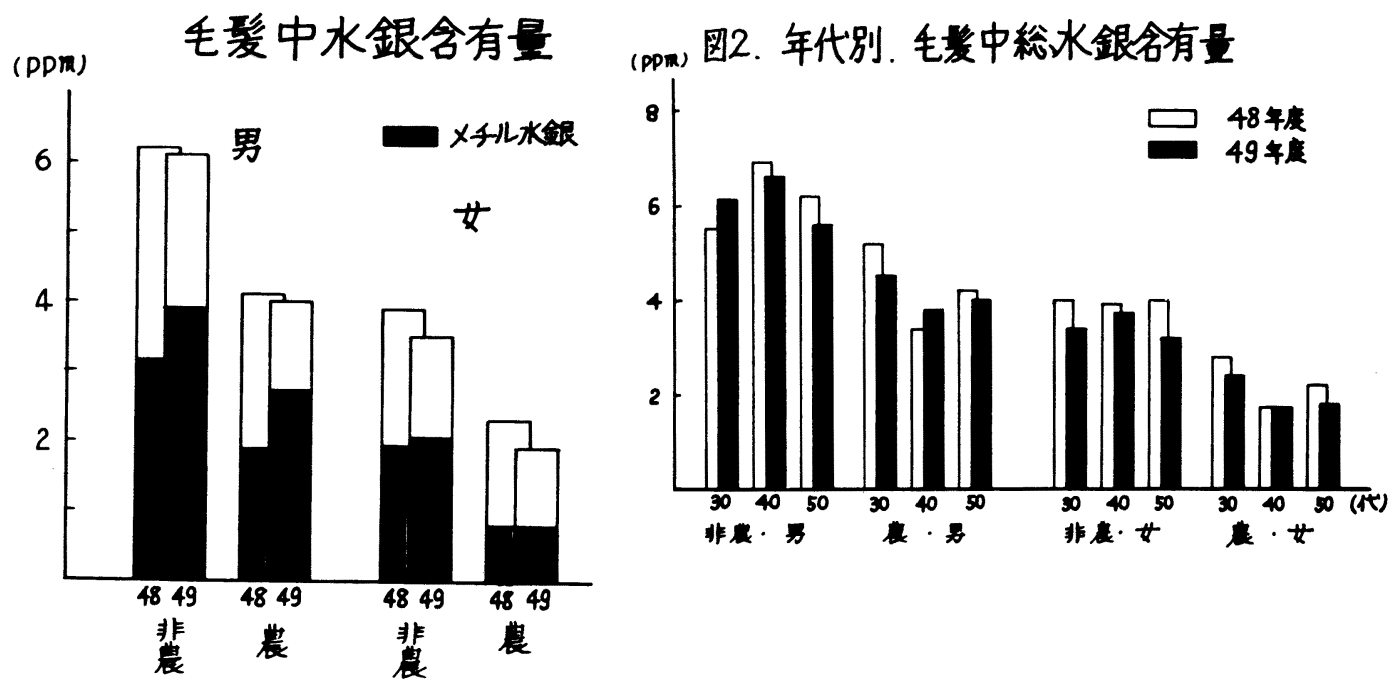




\section{雄薬中毒 IV}

326. 有機塩素荗の人体内残留几関与る研究（第6 報）

河西朗、浅沼信治、鈴木彰

(日本喱村医学研究所)

[はじめに]農薬として永年使用されていた有機塩素绪は、その残留性、安定 性がたからため、環境を污染し、動物体で濃縮され。食品等を通して。ん立てに 我々の人体に侵入する可能性がある。使用禁止後の有機塩素剂の人体内蓄栍の動

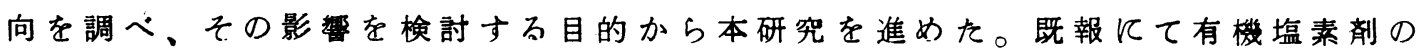
血中濃度と食品摄取との関連、使用禁止後の体脂肪残留量の変化、疾病と蓄積量 との関連。体内分布等につんて報告して来たが、今回は1975年における体脂肪 中蓄積量を中心に検討を加えたので報告する。

[研究方法]検体は入院患者の手術時。病理解部時にその脂肪組織を提供して もらん、すで報告した分析方法で測定した。なお蓄積濃度は、脂肪組織から脂 肪を抽出し、体脂肪当りの濃度として測定した。(表】) は調查の対象となつた人 員の性別、年令別の分布を示するのであり 高年令層に検体が集中しているのが特徽て

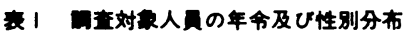

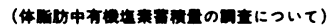
ある。

[調査結果] (1) 体脂肪中有機塩素蕃積量 につんて、（表2）は 45 検体の分析結果で ある。 $\boldsymbol{\alpha B H C 、} \boldsymbol{\beta} B \mathrm{H}$ 、 $\mathrm{PP} \mathrm{P}^{\prime} \mathrm{DDT}$ 、 PP'DDE、デイルドリンが全検体から検出さ れており、最高值はtota1BHCが18.561 p pmで、これは39才の女性、重症筋無力 症の患者であつた。tota1DDTは35.328 p pmて８3才の男性、心不全を併つた脳軟 化症の患者でつた。又ディルドリンの最 高值は0.935 p pmて、37才の女性て胆管 結石症の患者でつた。なお平均值は、 $\boldsymbol{\beta}$ BН C $2.957 \mathrm{ppm} 、 \mathrm{PP}$ DDE $8.639 \mathrm{p} \mathrm{pm}$ と他の成分に比べて多くなつている。なお 表にはあらわさなかつたか、年令別に44 才以下と。4 5 才以上に分類し、この群を更

\begin{tabular}{|c|c|c|c|}
\hline$F_{74}$ & 我 & 女 & 合 \\
\hline 1 - 97 & 0 & 0 & 0 \\
\hline $10 \sim 19$ & 0 & 1 & 1 \\
\hline $20-44$ & 5 & 12 & 17 \\
\hline $45-89$ & 8 & 19 & 27 \\
\hline 合 & 13 & 32 & 45 \\
\hline
\end{tabular}

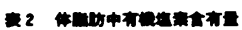

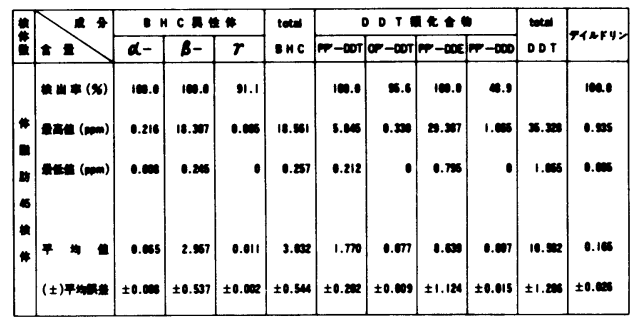

に男女の性別に分類して、年令別、性別の各群の平均值を比較するとt。taI一 BHC、totaIDDTともに45才以上の男性群が、他の群に比へて多くなつており

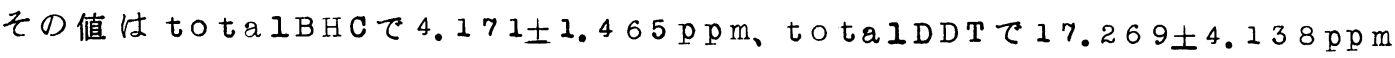
となつてんた。

(2)過去 5 年間の体脂肪中有機塩素の変化につんて、（表 3 ）は有機塩素各成分ご 
とに、各年度に調查した検体の平均值と平均誤差を求めたものであり。(図】)は totalBHC、totalDDT、デイルドリンにつんて。その変化を図表で示したすのである。

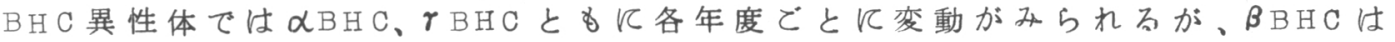
1971 年老最高飞1973年李で低下し、1974 年から増加している。又 totalBHC は1971年から1973年まで低下し、1974年に増加し1975年には1974年と任 同じ值を示した。DDT類化合物ではPP'DDTが1971年から低下し、1973年を最 低にその後增加している。又PPיDDは 1972 年を最低に、その後 3 年間増加の傾 向があ、ととに1975年には昨年度に比へ $40 \%$ 增加し。使用禁止に孛つた1971年の平 均值より多くなっているてとは注目にあた

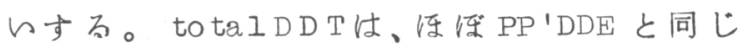
上5支傾向を示している。

デイルドリンは1972年に最高になり、1974 年亲で低下していたが、昨年から本年にか けて再び増加している。との変化は、同一 人の蓄積の変化を示するのではをいから、 一概に論ずるととは出来ないが、蓄積の一 般的傾向はみとめられると考える。

(3) 疾病と体脂肪中有機塩素蓄積量の関連 (図2 ) 岋、調査45 検体を疾病別飞分類し 疾病群どとに有機塩素蓄積量の平均值を求 め。その值の大きかつた7疾病を選んでそ の蓄積量を図にしたものである。るお蓄積 量の少加った疾病に属するものは、その 他として一括してその平均值を示しておい た。有機塩素の蓄積が、とれら疾病の誘因 を㞭しているか否玑ついては、更に詳細 古多方面からの検討が必要であろら。

同じ有機塩素飞属する污染物質である P C B などの蓄積量も調査する必要があるだるら。 孝お本年度は肝疾患の検体が採集出来孛 かつたため、それが除かれている。

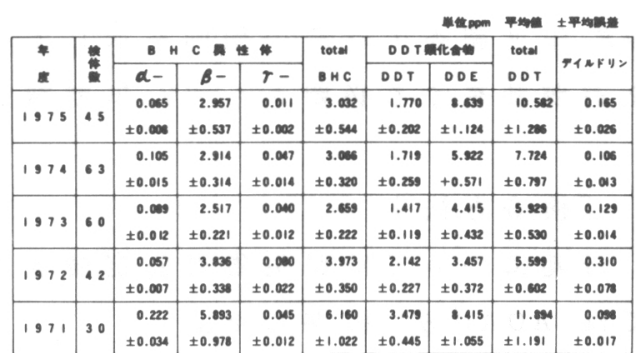

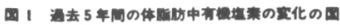

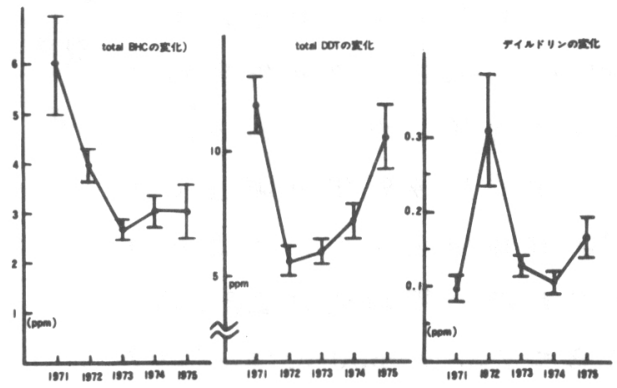

図 2 疾病別にみた体脂肪中有機塩素含有量

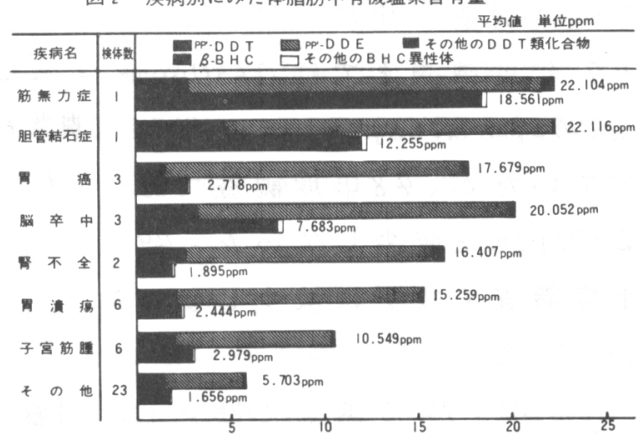

[結論](1)農薬として使用されていた有機塩素郕は、禁止後 5 年たつた現在も人 体に残留しており。ととRP'D DEは禁止直後の1971年から1972年にや〉低下 したものの、1975年には1971年の值よりも大きくなつており增加する傾向がみ られる。(口)疾病と体脂肪中有機塩素郕蓄積量関連については、筋無力症、胆管結 石、胃癌、脳卒中、督不全、胃潰瘍、子宮筋腫孛と、、その他の疾病群上りも多くの 蓄積がみられた。てれらにつんては更に詳細を検討が必要であるう。 


\section{～ 49 年度報告}

\section{秋田県厚生連平鹿総合病院農村医学研究所}

鉿木保男菅谷彪佐々木司郎

「緒言」

昭和 45 年以来、人体に於ける残留有機塩素量を測定してをたが、残留量は 48 年度調查では堿少傾向を示していた。しかしいまだ残留量は多く、それゆ え追跡調查する必要加 49 年度調查を行つた。

\section{「検查方法」}

母乳飞ついては厚生省の公定検查法に準じ、人体の脂肪組織や各臓器てつい てはAOAC法に準じた。

\section{表 1 母乳中の各年度に於ける平均値の比較}

\section{「成績」}

脂肪 $1 \mathrm{~g}$ 当り $\mathrm{ppm}$

表】は母乳中における $\beta$ な $\mathrm{BHC} \cdot \mathrm{DDE} \cdot \mathrm{P} . \mathrm{P}^{\prime} \mathrm{DDT}$ の年度別平 均値を比較した表てである。

$\beta-\mathrm{BHC}$ は 49 年度調查では 22 検体中全ての検体より検 出されその平均値は2.3/3 ppm であつた。 $\beta$-BHCにつにて49 年度調查と 45 年・46年・47年・ 48年度調查と比較してみると

\begin{tabular}{|c|c|c|c|c|c|}
\hline 農薬名各年度 & 45 年度 & 46 年度 & 47 年度 & 48 年度 & 49 年度 \\
\hline$\beta-\mathrm{BHC}$ & 0.650 & 3.200 & 6.105 & 2.901 & 2.313 \\
\hline D D E & 2.200 & 2.480 & 2.768 & 2.075 & 1.728 \\
\hline $\mathrm{P} \cdot \mathrm{P}^{\prime}-\mathrm{D} D \mathrm{~T}$ & 1.170 & 0.830 & 0.735 & 0.274 & 0.511 \\
\hline
\end{tabular}

表 2 人体脂肪中の各年度に於ける平均値の比較 47 年度調查までは $0.650 \mathrm{ppm}$ $3.200 \mathrm{ppm} \cdot 6.105 \mathrm{ppm}$ 年々増加 していたが、48年度調查では $2.90 / \mathrm{ppm}$ と減少していた。49 年度調查では更に減少し $2.3 / 3$ ppmとなつていた。

\begin{tabular}{|c|c|c|c|c|c|}
\hline 農楽名 各年度 & 45 年度 & 46 年度 & 47 年度 & 48年度 & 49 年度 \\
\hline$\beta-\mathrm{BHC}$ & 2.269 & 2.985 & 3.985 & 1.915 & 2.991 \\
\hline $\mathrm{DDE}$ & 3.244 & 1.268 & 2.822 & 1.486 & 1.776 \\
\hline$P \cdot P^{\prime}-D D T$ & 0.760 & 0.600 & 0.795 & 0.562 & 1.519 \\
\hline
\end{tabular}

$\mathrm{DDE} 4$ 4 年度調查では $\beta$-BHC 同様 $100 \%$ の検出率で検出されその平均值は、 $1.728 \mathrm{ppm}$ であつた。DDEについて年度別平均值を比較してみると47年度調查 までは $2.200 \mathrm{ppm} \cdot 2.480 \mathrm{ppm} \cdot 2.768 \mathrm{ppm}$ と増加の傾向を示していたが、48年度調查 では $2.075 \mathrm{ppm}$ 隇少し、49 年度調查では更に1.728ppmと減少している。

P. $P^{\prime}-D D T$ は 49 年度調查では検出率 $68.2 \%$ で検出されその平均値は $0.5 / / \mathrm{ppm}$ であつた。P.P'DDTについて年度別平均値を比較してみると48 年度調査ま では $1.170 \mathrm{ppm} \cdot 0.830 \mathrm{ppm} \cdot 0.274 \mathrm{ppm}$ と減少していたが、49年度調査では $0.5 / 1$ 
ppm と増加している。

表 2 は脂肪組織中における $\mathrm{DDE} ・ \mathrm{P} . \stackrel{\mathrm{P}}{\mathrm{C}} \mathrm{DDT}$ の年度別平均值を比較 した表である。

$\beta$-BHC は 49 年度調查では 25 検体 中全ての検体より検出され、その平均 值は2.3/3ppmであつた。 $\beta$ - $\mathrm{BHC}$ てつい て 49 年度調查と 45 年・46年・47年・ 48 年度の調查と比較してみると、47 年度調査むでは $2.269 \mathrm{ppm} ・ 2.985 \mathrm{ppm} ・$ $3.985 \mathrm{ppm}$ と年々増加の傾向を示してい たが 48 年度調查では $1.915 \mathrm{ppm}$ と減少 している。49年度調查では $2.99 / \mathrm{ppm}$ と逆に増加している。

$\mathrm{DDE}$ 子検出率 $100 \%$ で検出され、そ

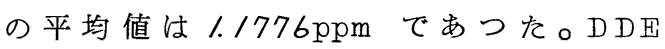
飞ついて年度別平均值を比較してみる と 45 年度では $3.244 \mathrm{ppm} ・ 46$ 年 1.268 $\mathrm{ppm} \cdot 47$ 年 $2.822 \mathrm{ppm} \cdot 48$ 年 $1.486 \mathrm{ppm} \cdot 49$ 年 $1.776 \mathrm{ppm}$ 隇少したり堌加したりし 49 年度䑏器中残留们㙁素量

\begin{tabular}{|c|c|c|c|c|c|c|}
\hline $\begin{array}{l}\text { 氏 } \\
\text { 名 }\end{array}$ & $\begin{array}{l}\text { 藏 } \\
\text { 器 } \\
\text { 多 }\end{array}$ & $\begin{array}{l}\text { 位: } \\
\text { 令 }\end{array}$ & $\begin{array}{l}\text { 農 } \\
\text { 非 } \\
\text { 別 }\end{array}$ & $\beta \cdot \mathrm{BHC}$ & D D E & $P \cdot P^{\prime}-D D T$ \\
\hline \multirow{5}{*}{ H. I. } & 大 & \multirow{5}{*}{54 才 } & \multirow{5}{*}{ 農 } & 4.325 & 2.583 & 0.728 \\
\hline & 皮 & & & 2.539 & 4.128 & 0.635 \\
\hline & 腎 & & & 0.492 & 0.245 & \\
\hline & 肺 & & & 0.254 & 0.069 & \\
\hline & 脾 & & & 0.062 & 0.079 & \\
\hline \multirow{5}{*}{ S. K. } & 皮 & \multirow{5}{*}{ 70才 } & \multirow{5}{*}{ 非 } & 3.273 & 1.677 & 2.642 \\
\hline & 腎 & & & 0.715 & 0.484 & 0.374 \\
\hline & 肝 & & & 0.142 & 0.130 & \\
\hline & 脾 & & & 0.083 & 0.234 & \\
\hline & 腷 & & & 0.109 & 0.101 & \\
\hline \multirow{5}{*}{ M. M. } & 大 & \multirow{5}{*}{ 59才 } & \multirow{5}{*}{ 非 } & 5.128 & 3.126 & 0.832 \\
\hline & 皮 & & & 4.128 & 3.006 & 0.756 \\
\hline & 腎 & & & 0.946 & 0.794 & \\
\hline & 肝 & & & 0.198 & 0.143 & \\
\hline & 脾 & & & 0.058 & 0.059 & \\
\hline \multirow{6}{*}{ K. T. } & 大 & \multirow{6}{*}{$64 才$} & \multirow{6}{*}{ 農 } & 0.956 & 1.178 & 0.429 \\
\hline & 皮 & & & 0.764 & 0.858 & 0.511 \\
\hline & 腎 & & & 0.371 & 0.335 & 0.081 \\
\hline & 肝 & & & 0.172 & 0.142 & \\
\hline & 瑝 & & & 0.163 & 0.061 & \\
\hline & 脳 & & & 0.115 & 0.057 & \\
\hline \multirow{4}{*}{ F. T. } & 大 & \multirow{4}{*}{ 75才 } & \multirow{4}{*}{ 非 } & 1.681 & 0.937 & 0.243 \\
\hline & 腎 & & & 0.640 & 0.873 & 0.258 \\
\hline & 肝 & & & 0.352 & 0.439 & \\
\hline & 脾 & & & 0.149 & 0.243 & \\
\hline \multirow{3}{*}{ S. F. } & 督 & \multirow{3}{*}{$62 才$} & \multirow{3}{*}{ 非 } & 0.415 & 0.375 & \\
\hline & 肝 & & & 0.280 & 0.235 & \\
\hline & 倿 & & & 0.113 & 0.128 & \\
\hline \multirow{3}{*}{ S. I. } & 腎 & \multirow{3}{*}{60 才 } & \multirow{3}{*}{ 農 } & 0.556 & 0.647 & 0.113 \\
\hline & 肝 & & & 0.131 & 0.224 & \\
\hline & 牌 & & & 0.101 & 0.148 & 0.008 \\
\hline
\end{tabular}

ているが全体的飞は隇少傾向飞ある。

P.P゙ーDDTは96\% の検出率で検出され、その平均值は1.776ppmであつた。年 度別平均值を比較してみるとDDE同様減少したり増加したりしている。45年 では $0.760 \mathrm{ppm} ・ 46$ 年 $0.600 \mathrm{ppm} ・ 47$ 年 $0.795 \mathrm{ppm} ・ 48$ 年 $0.562 \mathrm{ppm} ・ 49$ 年 $1.1519 \mathrm{ppm}$ で ある。全体的飞は僅加な゙ら增加の傾向飞ある。

表了は49 年度臟器中の残留有機塩素量を示した表である。BHCの残留して いる大部分は $\beta$-BHCで、いずれの検体からる検出された。DDEす $100 \%$ 検出さ れた。P.P'-DDTは脂肪組織・腎臓飞残留していて、他の臟器加は/検体中 办ら検出されただけであつた。

\section{「結〔論」}

母乳・人体の脂肪組織における残留有機塩素量の測定を行つた結果、全検体 よりBHC，DDTが検出された。年度別飞平均値を比較してみると45年度から 47 年度までは増加の傾向にあつたのが48年・49年度調查では減少傾向にあ る。但し、P.P'DDTだけは49年度調查では増加の傾向を示している。 臟器中の有機塩素はすべての検体で確認された。時に $\beta$-BHC、DDEはいずれの 検体加す検出され検出率 $100 \%$ であった同一個体での各臓器の残留量の此 較では腷・脾臓・盰臓・腎臓の順飞高い值飞なっている。 
328. 胎盤及心゙血姦の残留有機㦈素剂

\section{○高宫恒治内田昭夫（千葉大・医・贯医研）}

\section{（はじめい）}

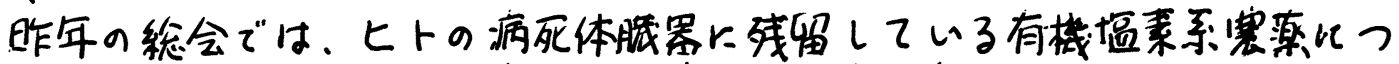

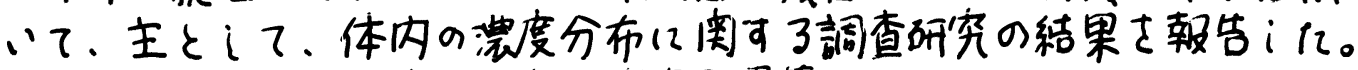

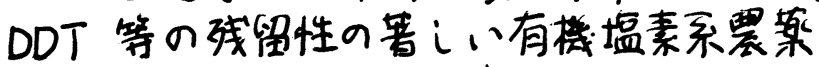
は使用分禁止にされて以来、かなりの年月 を経週にているとはい之，光の暊者な䂝留 性の故に体内残留の推移が注目されている。

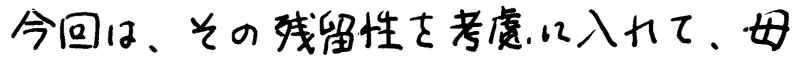
体の残留密祭の胎览への移行について。实

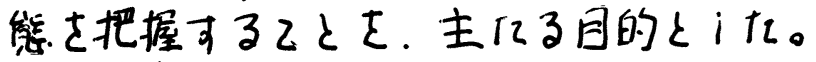

(模查方法)

妊嫜の出應時に打模体(胎盤、巴体 血、及心せい带血) 及心午菜市近郊震村住 表一1 利象人员の年领棈成 民の血夜は。本年3

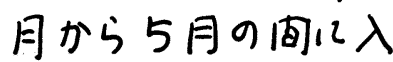
手i

胎盤は、5gさ処 理i。フロリジル。 クリーンアップは。 内䋃約1 cm 長文約 $30 \mathrm{~cm}$ のクロマト用 ガラス管を用い、フ ロリジルを5g。溶 出波( $15 \%$ Iーラ儿

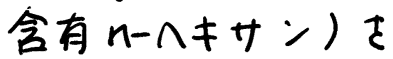
$50 \mathrm{ml} \varepsilon \mathrm{i}$ t2。

一方。血液は。昭 和45年涼定士 力 た方法い、おおたね なうっで、フロり ジル・クリーンアッ プは、胎盤の埸合に 従った（但し、フロ
表一2 胎盤。母体血及心゙せい带血における 队 $-B H C$ \& P P $-D D E$ の残留灙度

\begin{tabular}{|c|c|c|c|c|c|c|c|}
\hline $\begin{array}{l}\text { 硕体 } \\
\text { 播号 } \\
\end{array}$ & $\begin{array}{l}\text { 年令 } \\
(才)\end{array}$ & $\begin{array}{r}+6 \\
\beta-B H C \\
\end{array}$ & $\begin{array}{l}\text { 带血 } \\
P P^{2} D D E\end{array}$ & $\begin{array}{r}\text { 舟任 } \\
B-B H C\end{array}$ & $\begin{array}{l}\text { 遍 } \\
P P^{\prime}-D D E\end{array}$ & $\begin{array}{c}\text { 胎 } \\
B-B H C \\
\end{array}$ & $P P f D N E$ \\
\hline 1 & 18 & 2.1 & 1.8 & 7.7 & 4.7 & 6.0 & 3.2 \\
\hline 2 & 22 & 1.3 & 2.1 & 4.0 & 4.7 & 5,6 & 3.6 \\
\hline 3 & 27 & 1.2 & 3.3 & 5.7 & 12 & 5.2 & 7.0 \\
\hline 4 & 32 & 1,6 & 3.3 & 3.5 & 8.7 & 11 & 4.8 \\
\hline 5 & 26 & 5.0 & 3.0 & 12 & 5.5 & 12 & 2.8 \\
\hline 6 & 28 & 2.2 & 2.5 & 5.7 & 7.4 & 7.2 & 4.4 \\
\hline$\eta$ & 28 & 2.0 & 2.2 & 7.7 & 6.2 & - & - \\
\hline 8 & 28 & 1.7 & 3.0 & 5.5 & 8.5 & 6.4 & 4.8 \\
\hline 9 & 24 & 1.2 & 2.3 & 2.7 & 6.7 & 4.4 & 4.2 \\
\hline 10 & 20 & 1.0 & 2.3 & 3.0 & 7.5 & 3.6 & 4,0 \\
\hline \multicolumn{2}{|c|}{ 平均檤 } & 1.9 & 2.5 & 5.7 & 7,1 & 6.8 & 4.3 \\
\hline \multirow{2}{*}{\multicolumn{2}{|c|}{$\begin{array}{c}\text { 橝綮编差 } \\
\text { 最高檤 }\end{array}$}} & 1.1 & 0.53 & 2.8 & 2,2 & 2.8 & 1.2 \\
\hline & & 5,0 & 3.3 & 12 & 12 & 12 & 7,0 \\
\hline \multicolumn{2}{|c|}{ 最代值 } & 1.0 & 1.8 & 2.7 & 4.7 & 3.6 & 2.8 \\
\hline
\end{tabular}

(单位 $\mathrm{ppb}$ ) 
リジルを $3 \mathrm{~g}$. 溶去波さ $30 \mathrm{ml}$ と i 12 )。

(結果)

表一1 12、际 象人芫の年令侢 成を示门 12 。 奸嫜は，20代 12。震村住民12 40 代に集中 L 2 212。

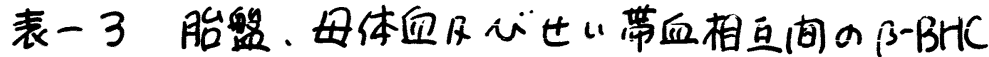
及心”Pṕ-DDEの畩度比ととの相阅性
表一212。妊嫜の出座时几おけ子各 模体几ついて、B-BHC \& pṕ-DDEの渭 度さ示にて。いずれ式、全模体に模 乙され、その他、ディルドリンが、母

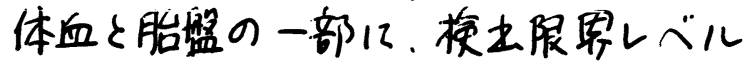
で残留いている可能性が示嗳されて。

母体血の B-BHC \& P '-DDEの灙度は。 平均值でほぼ等しく、胎盘及山゙せい带

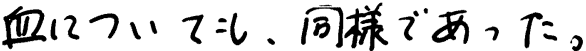

表一312、3種の梅体间の湄度の比

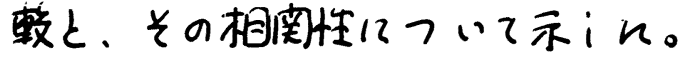

世带血几残留してい3 Pp'-DDEの演度は、いずれの埸台も、 母体血のほぼ30\%で。しが、光の 间に高い相闺があることが判った。

表一4n、曹村住民の血液について B-BHC \& PṔDDEの矵定值示示に。

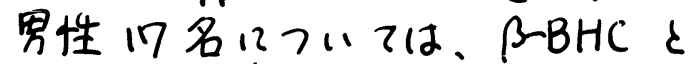
PṔ-DDEの渨度が、平均值でほぼ等し く、女性については、例数が方ないが 平均値では、男性の数值に近似してい tro

\section{( まとめ)}

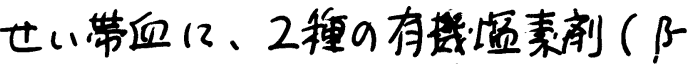
BHC \& PP'-DDE) か́. 模支限界レベ 儿で娭上されで。その湾度は、いず

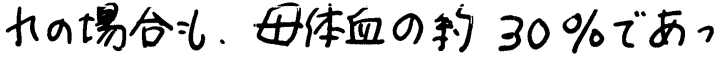
t.。

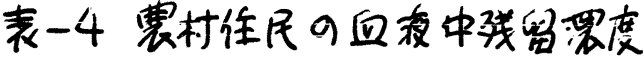

\begin{tabular}{|c|c|c|c|c|}
\hline 性䟞 & No. & 年令 & $B-B H C$ & $P\{-D O E$ \\
\hline \multirow{18}{*}{ 男 } & 1 & 43 & 2.0 & 5.8 \\
\hline & 2 & 51 & 3.1 & 5.8 \\
\hline & 3 & 43 & 29 & 3.1 \\
\hline & 4 & 46 & 2.5 & 5.4 \\
\hline & 5 & 44 & -3.7 & 8.2 \\
\hline & 6 & 46 & 2.0 & 8.2 \\
\hline & 7 & 44 & 18 & 5,7 \\
\hline & 8 & 46 & 6.2 & 3.2 \\
\hline & 9 & 46 & 3.7 & 6.0 \\
\hline & 10 & 46 & 3.2 & 7.5 \\
\hline & 11 & 46 & 7.2 & 45 \\
\hline & 12 & 46 & 3.2 & 3.5 \\
\hline & 13 & 47 & 5.7 & 5.2 \\
\hline & 14 & 46 & 6.5 & 9.0 \\
\hline & 15 & 45 & 25 & 5,5 \\
\hline & 16 & 46 & 3.5 & 5.5 \\
\hline & 17 & 44 & 3,5 & 3.2 \\
\hline & \multicolumn{2}{|c|}{ 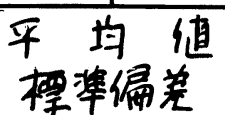 } & $\begin{array}{l}4.6 \\
3.7\end{array}$ & $\begin{array}{l}5.6 \\
1.8\end{array}$ \\
\hline \multirow{4}{*}{ 女 } & 18 & 42 & 8,3 & 4.7 \\
\hline & 19 & 45 & 6,0 & 3.2 \\
\hline & 20 & 43 & 3.7 & 4,0 \\
\hline & $\begin{array}{l}\text { 平 } \\
\text { 橝至 }\end{array}$ & 健 & $\begin{array}{l}6.0 \\
2.3\end{array}$ & $\begin{array}{l}3.9 \\
0.75\end{array}$ \\
\hline
\end{tabular}


329.2、4、5ーTおよびこれに関連する物啠の細胞遺伝学的研究

藤田公生、藤田弘子、船崎善三郎

（長野県・佐久総合病院）

\section{目的}

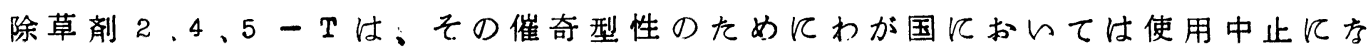
つている。船崎は1971年にヴエトナムを訪れた際に本郕の影響を知り、わが国 の山林の調査によつて、使用中止後も土裹中に残留しているととを明らかにした。 しかしなから本郕の催奇型性は不純物としてふくまれているがイオキシンのため であるとい5考えから、純度の高い2、4、5一Tが得られるよ5になつて。使用 の許可されている国もある。そてで䊶度の高い2、4、5ーTによつて細胞遺伝学 的にみて影響がみられるかどらか、また影響がみられるとすれば2、4、5一Tそ のものの作用をのかダイオキシンによるものをのかといら点を中心に検討を加え た。

方法

健康成人の末梢静脈血をへバリン採血し、PHAを加えた培善液中で48時間

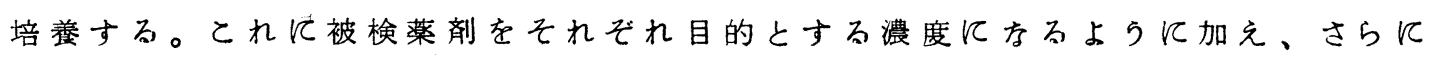
24 時間培養を続ける。培養終了 3 時間前にコルヒチンを加える。アルコールー 酢酸固定、低張処理を行なつて染色体標本をつくり、顕微鏡下に観察した。

図1各物質の構造式

上から2。4-D；2、4。5-T；2、4、5-T P ; ダイオキシン

CI<smiles>O=C(O)COc1ccccc1</smiles><smiles>O=C(O)COc1ccccc1Oc1ccccc1OCC(=O)Oc1cccc(Cl)c1</smiles>

2,4-dichlorophenoxyacetic acid

$2,4,5$-trichlorophenoxyacetic acid

$2,4,5$-trichlorophenoxypropionic acid

$2,3,7,8$-tetrachlorodibenzo$-p-d i o x i n$ 
被験薬戍はダウ・ケミカル社のものを譲与を受けて使用した。使用した2、4、

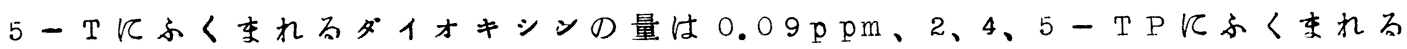
ダイオキシンの量は $0.053 \mathrm{ppm}$ 以下であつた。

結 果

図2に染色体切断頻度と薬剤の澧度との関倸をグラフル示した。

図2 2、4、5 - T および2、4、5-TP 濃度と染色体切断頻度 左.図の点線は、2、4。5-TP中にふく军れるダイオキシン 量が2、4、5ーTより2 桁少をいとすればふたつの曲線が任 任一致するとと走す。

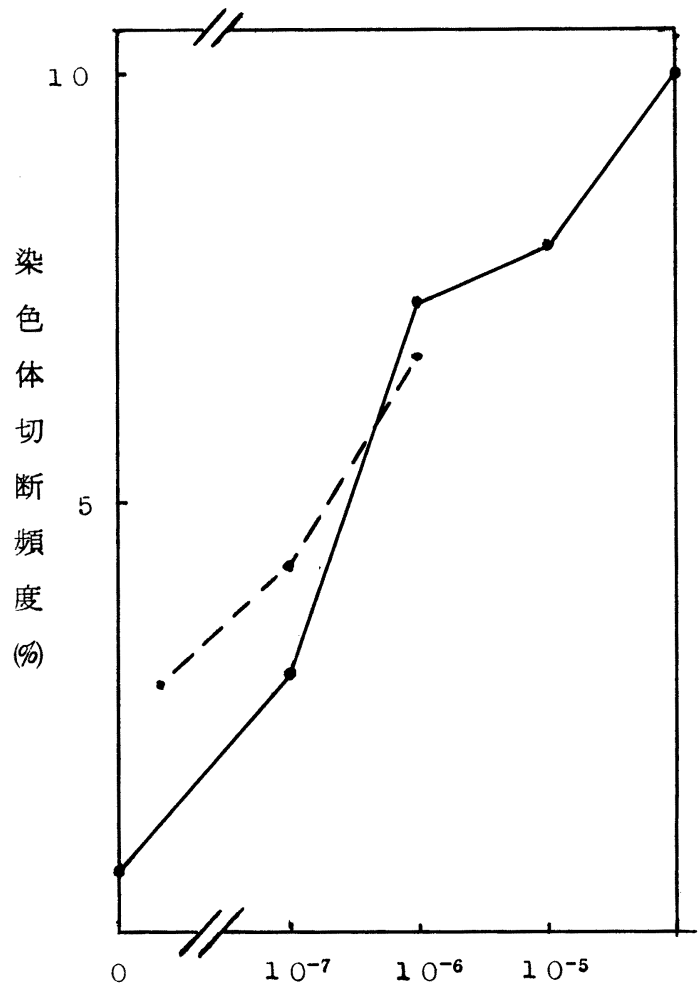

2、4、5- T 濃度 (モル/ $\boldsymbol{\ell})$

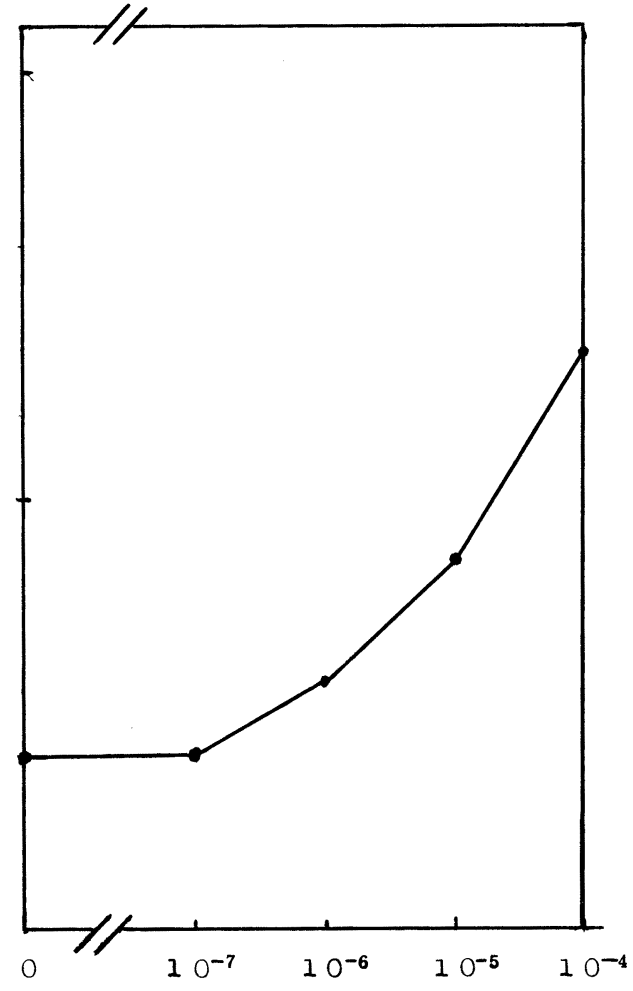

2、4、5-T P 濃度 (モル/ $\boldsymbol{l})$ 
417.八千穂村における肝炎 $\mathrm{B}$ 抗原調查 4 年間の結果

○藤田公生、寺島重信、松島松翠、高橋松雄

( 長野罢・佐久総合病院 )

目的

肝炎B抗原の発見によって新らしいアプローチの可能となつたB型肝炎の疫学 的調査の場として、住民の健康管理の意味をふくめて、八千穂村がとりあげられ てから5年目になる。現在まての調査から、肝资の流行をみず、また散発性の肝 炎の発生も少をい静か子山間農村における肝炎Bウィルスの感染の実態の一端を 明らかにしたん。

方法

対象は長野県南佐久郡八千穂村の15 オ以上の農民である。冬期飞村内を巡回 し健診を行

antigen)、抗体、肝機能を調べた。抗原陽性者につんては追跡調査を行をつ た。訮炎B抗原検出飞はIAHA法、PHAI法、RPHA法、RIA法、抗体検出 にはPHA 法、RIA法を用にた。

結 果

抗原陽性率、抗体陽性率は初年度でそれぞれ1.3\%および 0 。 $0 \%$ であり、そ の後る大をな変動はみられない。日本国内の他地域と比較して低率を傾向を示し ている。陽性者は性別では男性、年令別では20〜30代に多らのは一般的孛傾 向であ。抗原陽性者のらちで肝機能異常のみられたのはでく少数である。サブ タイプの判明したものは、adwがュ例あつた以外は全例adrであつた。

抗原陽性者の消長を上図に示した。黒印はその時点で検索を行をい、肝機能異 常を示さなかつたととを意味し。白印は肝機能異常のみられたととを意味する。

家族性を示した家系を下図に載せた。四角は男性、円は女性でり、黒は持続 抗原陽性者、半分黒らのは一時的に抗原の検出されたととのある者、斜線は抗体 陽性者である。小さい四角をいし円は故人を示し、そのなかて黒く塗つてあるの は肝かんないし肝硬变であつたととが疑われる例である。 

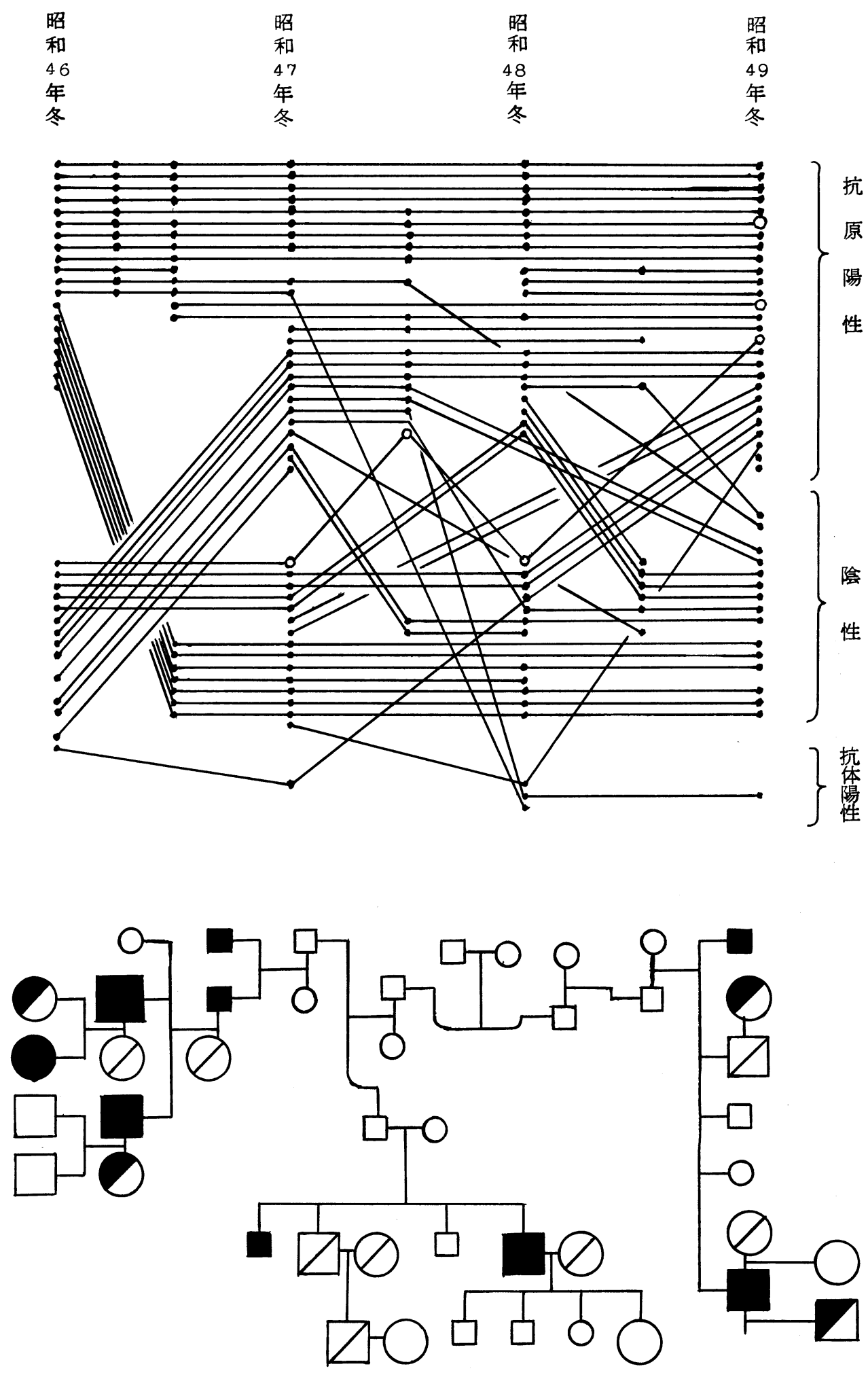
418. 茨城県農村地区住民飞おけるA U 抗原調査成績

平沢博, 酒井健次, 井坂信之, 中山恵子 杉浦貴四郎（土浦協同病院）

（目的）荻城県厚生連では，県下の農村地区住民の健康管理とし て, 肝機能検查, G O T, G P T, コレステロール,コリンエステラ 一ゼをおこない検討を重ねてをた。今回，当病院中央検查科で，上 記の肝機能検查に加えて, 近年, 問題視されているA U 抗原について $\mathrm{R} I$ 法による検出を試みた。対象は各農協地区別住民，当病院の外来 および入院患者，輸血用パイロット，医療従事者の群で，それぞれの 陽性变を比較検討してをたので，ててに報告する。

(剆定方法の原理) 固相法を利用する $\mathrm{R} I$ 法で， $\mathrm{D}$ 社発売オ一ス リアIIーI 25 を用いた。李ず抗体をコ一トしたビーズ玉をトレイに 落とし，被検血清を加えてインキュベーションすると，A U 抗原が存 在すれば，抗体一抗原の結合物が生成される。さらにI一125で標 識された抗体を加えると，抗体一抗原一標識抗体のサンドウィッチ型 の結合物がビーズ玉に固定される。このビ一ズ玉の放射能をカウント し,コントロ一ルの值に比較して, 陽性および陰性を判定する。

(測定方法飞ついての問題点)

検体採取については，とくにピパッティングにおける洗㴰回数と洗

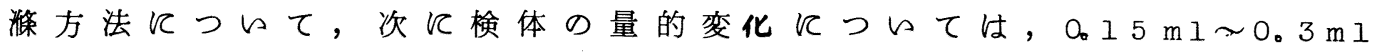
(.術式では0。2 mI) の範囲で，カウント数の変動を調べてみた。

まず,コンタミネーションについて, ピペットの洗格なしに, 次検 体を採取した場合，陽性例（カウント数の高いるの）のあとには，陰 性の検体に，そのA U 陽性例がコンタミとして，数検体にまで影警す る。次にピペットの水洗が不十分な場合には，次検体の採取は洗浟な しの採取と同じくコンタミを重ねていく。ピペットの洗治に水を使用 せず陰性血清で洗揲した場合には，全くコンタミをおこさなかつた。

以上のてと加ら，検体採取の場合には，使い捨てのピペットを検体 ごとに使用するか，または陰性血清でピペットを洗い次検体を採取す るととによつて，コンタミを防ぐてとがでをる。

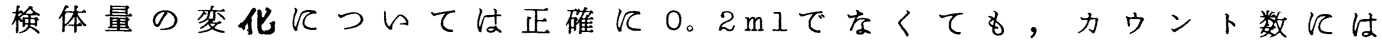
影響なく，慣れると試験管から直接トレイに入れて，測定するととも 可能である。

（成績）

農村地区における A U 抗原の陽性率は表1飞示す如く，平均1。4\% であるが，吉沼農協と新生開拓農協は2。1\%，2。8\%といくぶん陽性 
变が高くなつているが，てれらの陽性者の肝機能を調べてみると， G O T, G P T, コレステロ一ル, コリンエステラ一ゼの値はいずれ も正常であつた。

录工各慗协地区别のAU陽性摔

\begin{tabular}{|c|c|c|c|c|}
\hline 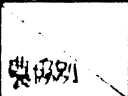 & 梳铪者数 & 俭性者政 & 咸性者呚 & 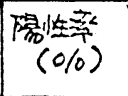 \\
\hline 土濡 & 444 & 439 & 5 & 1.12 \\
\hline 㹩息 & 130 & 128 & 2 & 1.53 \\
\hline 麻生 & 190 & 187 & 3 & 1.57 \\
\hline 吕沼 & 97 & 95 & 2 & 2.06 \\
\hline 美浦 & 77 & 77 & 0 & 0 \\
\hline 新地開颃 & 109 & 106 & 3 & 2.57 \\
\hline & 1047 & 1032 & 15 & 讶 1.43 \\
\hline
\end{tabular}

表2 当病院の外来入院思者别AU淂性率

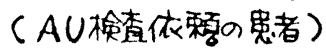

\begin{tabular}{|c|c|c|c|c|}
\hline & 是者敬 & 险任者故 & 䦭性者荍 & $\begin{array}{l}\text { 箱此室 } \\
(\%)\end{array}$ \\
\hline 入院思者 & 385 & 368 & 17 & 4.41 \\
\hline \multirow[t]{2}{*}{ 外采思者 } & 312 & 291 & 21 & 6.73 \\
\hline & 697 & 659 & 38 & 5.45 \\
\hline
\end{tabular}

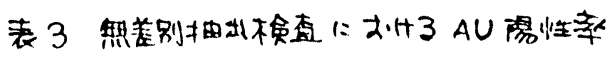

\begin{tabular}{|c|c|c|c|c|}
\hline & 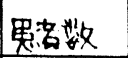 & 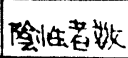 & 爀生老嚾 & 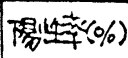 \\
\hline 入院琴者 & 103 & 98 & 5 & 4.85 \\
\hline 外来鬼者 & 180 & 178 & 1 & 0.55 \\
\hline & 283 & 277 & 6 & 2.12 \\
\hline
\end{tabular}

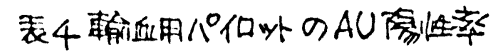

\begin{tabular}{|c|c|c|c|}
\hline 模的代教 & 㓌性者敨 & 县此者奻 & 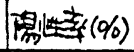 \\
\hline 233 & 230 & 3 & 1.28 \\
\hline
\end{tabular}

表 2 は, 当病院外来飞て受診時に $\mathrm{A} U$ 検査依頼のあつた患者数と，入 院患者でA U 検查依頼のあつたもの についての集計である。

外来入院別の陽性胨が入院患者上 り外来患者の汪うがわずか飞2。32 $\%$ 高く，また表】と比較してみると 当病院での陽性はいくぶん高く出 ている。次飞, A U 陽性审加外来患 者の䄈う若干高く出ているため， 我々はとの陽性率が，検査低頼のな い検体加ら無差別飞抽出して検查し た場合と，同椂の陽性率を示す加を 調べた。

結果は反対に，入院患者の性うが 高く，表 3 がそれを示している。し 加し，乙の陽性㪄の違的，検査件 数の多少にる関係があるので，乙の 無差別検查の例数を堌して，検討し てみたい。

生た，健康と思われる農協地区住 民からす，約 1。4\%の陽性者がある ことから, 輸血用保存血飞ついて, A U 抗原の陽性韯を調べてみた。そ の結果は表 4 の通りである。

さらに，毎日患者に接している医療従事者には，A U 感染が高いと 思われるので, とくに, 中央検查科職員, 看護婦, 医師について調べ てみた。例数 87 件で, 幸いにしてA U 陽性者は現われなかつた。

(結語) 以上, 我々は健康者群となんら加疾病を的群につい ての比較検討をおてなつた。表が示すように，当病院でのA U 陽性率 は, 健康者群飞比べて, 約 3 。8 倍高く, をた注目すべをととは，A U 陽性の輸血用保存血が1。3\%の割合で使用されるととにある。検出感 度の高いRI法によつてのみ検出されたのであつて, 一般的飞用いら れている S R I D 法では，てれらを見逃すととであろう。 A U 抗原検 出には, 設備等の問題すあろうが, 出来るだけ $\mathrm{R} I$ 法で測定するとと が望をじい。 


\section{9。一農協病院に打けるH B 抗原の検索について}

$$
\begin{aligned}
& \text { ○清水伸三 - 中島修 } 川 \text { 合信行 } \\
& \text { 赤堀睦子・細野かほる }
\end{aligned}
$$

静 岡 厚 生 病 院

（目的）近年、H B 抗原は血清肝炎の発症と密接な関係があるといわれ、急性肝炎、肝硬 変、原発性肝痁の発症病理との関係が考察されている。H B 抗原はその検出に数種の方法がある が、R I 法が敏度、容易度に於て優れているとされている。吾々は R I 法により病院職員、妊婦 ・新生児、肝疾患患者の H B 抗原の検出を行ない、その動態を調べた。また H B 陽性プール血清 により数種の不活化消毒剤の効果を調べた。

（方法） H B 抗原：So1 idphase を利用したRadioimmunoassayキットで外面に抗体を コーティングしたビーズと、被検血清をトレイ中でインキュベートし、抗体と H B 抗原を結合さ せる。後、 ${ }^{125} \mathrm{I}$ 標識抗体を加え、抗体一抗原— ${ }^{125} \mathrm{I}$ 標識抗体のサンドイッチ型結合物を固定し、 シンチレーションカゥンターで測定する。

免疫グロブリン定量：ヘキスト社トリパルチゲン（IｇＧＩＩＡ、I g M ）に稀釈被検血清を注 入し、一定時間静置後、リングを測定、算出する。

消毒剂の不活化効果測定: H B 陽性プール血清と、各消毒剂を $25^{\circ} \mathrm{C} 60$ 分作用させた後、洗滌し 標識抗体を加え、シンチレーションカゥンターで測定する。

（結果）当院に於て、過去14ケ月間に検査した H B 抗原陽性の動態は、対象人員 2,243 名 中、陽性者 105 名、陽性率 $4.68 \%$ であった。病院職員、姡婦健診の陽性率は（表－1）の通り である。

また、肝疾患々者 310 名 (表-1）健康人 中、陽性者 18 名、陽性率 $5.81 \%$ の結果を得た（表 $-2)$ 。

H B 抗原陽性妊婦 5 例、 及び H B 抗原陰性妊婦 240 例について（表一 - ）また、 H B 抗原陽性妊婦の出産時 の検査の結果（表一 4) を 得た。

\begin{tabular}{|c|r|r|r|r|r|r|}
\hline & \multicolumn{3}{|c|}{49} & \multicolumn{3}{|c|}{50 年 } \\
\cline { 2 - 7 } & 人 員 & \multicolumn{1}{|c|}{$\oplus$} & $\%$ & 人 員 & \multicolumn{1}{|c|}{$\oplus$} & $\%$ \\
\hline 病院職 員 & 316 & 3 & 0.95 & 316 & 5 & 1.58 \\
娃婦 健 診 & 155 & 5 & 3.23 & 578 & 25 & 4.33 \\
\hline
\end{tabular}

\begin{tabular}{|c|c|c|c|}
\hline & 人 & $\oplus$ & $\%$ \\
\hline GOT 30 unit $\downarrow$ & 151 & 5 & 3. 31 \\
\hline $30 \sim 60$ & 103 & 7 & 6.80 \\
\hline 60 & 56 & 6 & 10.71 \\
\hline
\end{tabular}

$$
\text { (表-2）肝疾患々 者 }
$$

（表-3）出産時母児間

\begin{tabular}{|c|c|c|c|}
\hline & & $\mathrm{H} \mathrm{B} \oplus 母$ & $\mathrm{HB} \ominus 母$ \\
\hline 児 & 臍帯血 $\oplus$ & 1 & 2 \\
\hline 児 & $" \quad \ominus$ & 4 & 238 \\
\hline
\end{tabular}
(表-4) 陽性母親について

\begin{tabular}{|c|c|c|c|c|}
\hline & 羊 水 & 棰 液 & 母 乳 & 尿 \\
\hline$\oplus$ & 0 & 1 & 1 & 1 \\
\hline$\ominus$ & 1 & 4 & 3 & 3 \\
\hline
\end{tabular}

$\mathrm{H} \mathrm{B}$ 抗原の不活化消毒剤について、 $25^{\circ} \mathrm{C} 60$ 分作用させた結果は（表 - 5 ）の通りである。 
(表 -5$)$

H B $\oplus$ プール血清による不活化消毒剤の効果

\begin{tabular}{|c|c|c|c|c|c|c|c|c|}
\hline 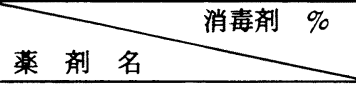 & 5.0 & 2.5 & 1.25 & 0.68 & 0.32 & 0.16 & 0.08 & 0.04 \\
\hline $\begin{aligned} \text { 次亜塩素酸ナトリウム } \\
\text { 不活化 \% }\end{aligned}$ & 100 & 100 & 100 & 100 & 100 & 99.7 & 98.4 & 93.6 \\
\hline 石炭酸 & 89.8 & 22.3 & 0 & 0 & 0 & 0 & 0 & 0 \\
\hline クレソール石けん夜 & 63.6 & 39.7 & 28.7 & 22.0 & 0 & 0 & 0 & 0 \\
\hline 逆性石けん液 & 12.7 & 13.6 & 14.3 & 24.4 & 12.9 & 10.2 & 8.3 & 0 \\
\hline ヒ ビ & 31.5 & 25.3 & 16. 9 & 9.6 & 0 & 0 & 0 & 0 \\
\hline 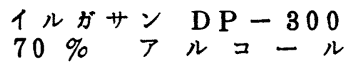 & 79.0 & 68.1 & 65.7 & 57.9 & 44.9 & 41.9 & 39. 0 & 25.3 \\
\hline ラ 1 ポ ン $\mathrm{F}$ & $60.7^{-}$ & 70.3 & 64.8 & 50.4 & 32.4 & 22.6 & 0 & 0 \\
\hline
\end{tabular}

また、患者 A 。Bについて H B 抗原の陰性化した例と、引続き陽性の例を（表－6）（表－7） に示す。

(表-6) 患 者 $\mathrm{A}$

\begin{tabular}{|c|c|c|c|c|c|c|c|}
\hline D a t e & HB & HB/Neg & I gG & I gA & I gM & RA & TR \\
\hline 6.18 & + & $7634 / 425$ & 1960 & 296 & 473 & \pm & 本 \\
\hline 6.27 & + & $4108 / 403$ & 1640 & 262 & 350 & - & \\
\hline 7.8 & + & $3438 / 715$ & 1520 & 254 & 350 & - & \\
\hline 7.15 & + & $1208 / 334$ & 1520 & 246 & 360 & - & \\
\hline 7.23 & + & $372 / 156$ & 1510 & 250 & 348 & - & \pm \\
\hline 7.27 & + & $344 / 156$ & 1630 & 244 & 333 & - & \\
\hline 8.23 & \pm & $360 / 188$ & 1840 & 264 & 278 & - & + \\
\hline 9.10 & - & $76 / 111$ & 1800 & 264 & 292 & - & \\
\hline 9.24 & - & $56 / 111$ & 1800 & 295 & 306 & - & \pm \\
\hline 10.8 & - & $72 / 377$ & 1980 & 280 & 292 & - & \\
\hline
\end{tabular}

(表 - 7)

患 者 B

\begin{tabular}{|l|c|c|c|c|c|c|c|}
\hline Da t e & HB & HB/Neg & I gG & I gA & I gM & RA & TR \\
\hline 6.13 & + & $11534 / 425$ & 1690 & 193 & 324 & \pm & H \\
\hline 6.27 & + & $5618 / 403$ & 1630 & 179 & 233 & - & \pm \\
\hline 7.8 & + & $4102 / 715$ & 1580 & 179 & 229 & - & \pm \\
\hline 7.15 & + & $1804 / 334$ & 1580 & 179 & 233 & - & \\
\hline 7.22 & + & $794 / 156$ & 1580 & 172 & 225 & - & \pm \\
\hline 7.29 & + & $670 / 156$ & 1580 & 193 & & - & \\
\hline 8.3 & + & $904 / 130$ & 2220 & 184 & 229 & - & \\
\hline
\end{tabular}

（考察） われわれの所属する農協病院に於ける H B 抗原陽性の動態は、病院職員の場合 $\mathrm{S}$ 49 年陽性者 3 名、陽性率 $0.95 \%$ が、S 50 年に陽性者 5 名、陽性率 $1.58 \%$ と漸増している。S 50 年の陽性者 5 名の内訳は (1) S 49 年から継続して陽性の者 3 名、(2)他病院からの移動 1 名、 (3) 去年陰性で、この 1 年に感染した者1名となっており、その何れのケースも肝炎の発症を予防する という見地からすれば、(1)のケースは特に重要であり、(2)のケースは遡って前任地の動態を検索す る必要があり、(3のケースは院内感染の明らかなものとして種々の問題を提起している。

肝疾患々者でGOTの高単位グループは、明らかにH B 抗原陽性率が高く、肝炎患者及び、肝炎 患者に関連する物件の厳重な管理の必要性を示唆している。

消毒薬については、すくなくとも血夜、厤便等有機物中に含まれる H B 抗原の常備消毒薬とし ては、次亜塩素酸ナトリウムの最終濃度が $1 \%$ 以上になる液を、毎日作製して60 分以上浸漬する ことが望ましい。日常、好んで使用される一連の消毒薬ではその効果は、ほとんど期待出来ない。

今後に課された問題として、新生児の $\mathrm{H}$ B 抗原陽性転化、家系の追究、抗体の变動、整形外科 領域の H B 抗原の動向を握むべく目指したい。 
420 .

HB抗原・抗体の测定法と集団榆㟝に於ける

〔はじめに〕

HB抗原・杭体の保有率に関する検討

○森下昌子筒井淳平長頛弘明 加藤 仁瀬古 義雄增田朝子

(三重厚生連中势総合病院中央臨床検查科)

近年、HB抗原の测定には、種マの方法が検討されてきま1たが、今回。 我々は集団検診に於、て、SRID C E P R R H A R I A 4 4法に つき検討しました。又.HB抗体につてもCEP・RIA・PHA法で 制定し、集田検診でのHB抗原・抗体の保有率について検討にた。

[方法】

以下にのベるごとくの市販キットを使用した。

$H B$ 抗原

-SRID法（武田一抗Au-P血清平板）

一定力洒の抗体を含ませた寒天平板に一定の穴をあけ。:れに被 検血清を入兆、寒天内の抗体と被拾血清中の抗原七反応させ、沈 降りングを作る現象を利用(た方法で24時間後判定。

。C EP法（ヘキスト一Au/sH抗原検出試菜）

寒天ゲル内で。杭原・抗体に一定の直流電流を加元、泳彭させる

上、抗体が形成されて、るるr-Globulinは㓌柾侧入，抗原が形成され て、万蛋白は陽極側に泳動され、衔突点で沈降線子形成する現象

を利用(た方法で3 $\mathrm{mA} / \mathrm{cm} 30$ 分泳動後判定。

。RPHA法 (ダイナボットーオーセル)

HB抗体をcoating ( た赤血球と被検血清中の抗原七反㐫させ、血 球疑集的有無に上り判定する。2 時間後判定。

○R I A 法 (ダイナボットーオースリアII 25)

抗体をcoatingしたビーズと被梌血清中の抗原と反応させ、乞の後 ビーズについた抗原に125Iで標誐いた抗体を反㐫させ、シンチし

一ションカウンターで矵定する。

HB抗体

。RIA法 (ダイナボ・トーオーサブ)

抗原をcoating (たビーズを被検血清中の抗体と反応?世、首の後 ビーズにつ、・た杭体に125Iで標瀻した抗原を反応さ世。シンチし 一ションカウンターで测定する。

-PHA法 (エーザイ)

HB抗原を coating (た赫血球に被険血清中の机体を反応させ、血 球凝集の有無に上り判定する。2時間後判定。 
集団㭘診者 268 名について4 法を实施1た結果、表Iのジとく、SRI D・CEP法では陽性を示した者はなく。RPHA法では1.5\%。RIA法 では3.0\%の頻度で陽性となった。又、抗体では、RIA法で19.6\%の陽性 率を示l，RIA法陽性者のみについてPHA法を行なった結果、51名中 41名陽性となった。

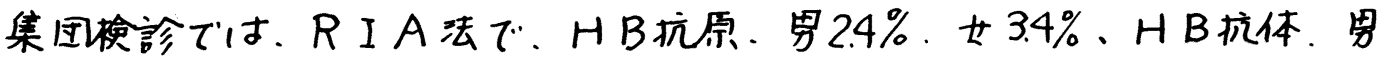

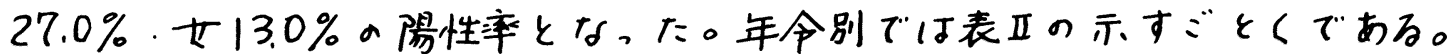
地域别では、四のような地域につき实施した結果、表正の示すジとくとな ,た。

\begin{tabular}{|l|r|r|r|r|r|r|r|}
\hline 表 I & SRID & CEP & RPHA & RIA & CEP & RIA & PHA \\
\hline 查查数 & 268 & 268 & 268 & 268 & 268 & 260 & 51 \\
\hline 陽性数 & 0 & 0 & 4 & 8 & 0 & 51 & 41 \\
\hline 5 & 0 & 0 & 1.5 & $\xi 0$ & 0 & 19.6 & 80.4 \\
\hline
\end{tabular}

\begin{tabular}{|c|c|c|c|c|c|c|c|c|c|c|c|c|}
\hline 表 II & \multicolumn{6}{|c|}{ HB 抗原 } & \multicolumn{6}{|c|}{ HB 抗体 } \\
\hline 年代 & 20 & 30 & 40 & 50 & 60 & 合計 & 20 & 30 & 40 & 5 & 60 & 合计 \\
\hline 全直数 & 42 & 56 & 69 & 56 & 45 & 68 & 41 & 56 & 65 & & 42 & 60 \\
\hline 性数 & & & 2 & & & & & 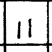 & 15 & 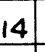 & & 5 \\
\hline 頻度 $(\%$ & 7.1 & 5,4 & 2.9 & 0 & & 3.0 & 2.2 & 196 & 23.1 & & 14. & 19. \\
\hline & 25 & 24 & 29 & 29 & 16 & 23 & $1<5$ & 25 & 120 & 29 & 15 & 12 \\
\hline 㥪性数 & & & 1 & 0 & 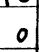 & 3 & 3 & 7 & 9 & 9 & 5 & 3 \\
\hline 神安(\%) & 4.0 & 4.2 & 3.4 & 0 & 0 & 2.4 & 2.0 & 28,0 & 32.1 & 310 & 33 & 27 \\
\hline 数 & 17 & 32 & 40 & 27 & 29 & 45 & 16 & 31 & 37 & & 27 & 138 \\
\hline 险性数 & 2 & 2 & 1 & 0 & 0 & 5 & 2 & 4 & 6 & & 1 & 18 \\
\hline $1 \%$ & & 63 & & & & 34 & & & & & & 13 \\
\hline
\end{tabular}

(陽性となり肝峨能果常を示(た者は 除外 (た)

\section{〔考察・結語〕}

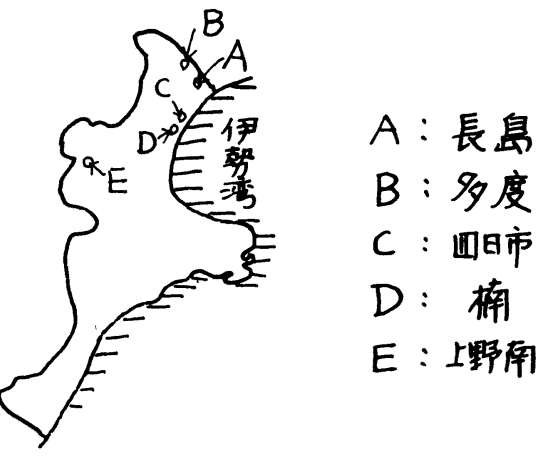

以上のようだことから則定法では、時間的にはC E P 法が早く、SRI D法は䉍単ではあるが、感度が鈍く、R、R $A$ 法では時間がかかるが、感度

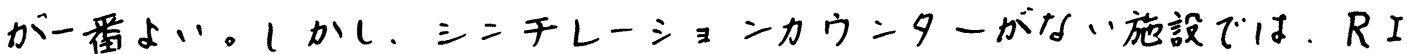
A法につぐ感度のよ・RPHA法が良・様に思う。抗体でも同様にPHA 法か時間的にもRIA法より早く、感度も良”が・ cost面で今一つの間题 があるのではないかと思われる。

集团検診では、抗原ではやや女性の方が陽生率は高く出たが、抗体では 男性の方が高・.年领では、抗原は若年愿に多く陽性者が出たが、抗体 では50代にタタく陽性を示した。又、地域別には、有意の差が就わうれなか ,

このように震村においても、H B抗原・抗体の健康保有者がいることは、 感染源のは、きりはない現在，大きな問題と言えよう。

最後に。二の報告に三゙场力下さった方マに深く感谢致します。 
421. 曹村の集团健診時におリる䀒触知上旰機能检奋について

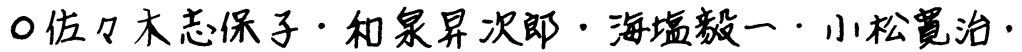

$$
\begin{aligned}
& \text { (由利組合総合病院・地域保健活敏部) }
\end{aligned}
$$

徒来集団健診時に扬いて，对象者去仰卧位にして肝触知を行い，触知士 几下者に对して旰機能梌㚗を实施してきている。昨年地域住民232名に 䀒触知七肝僟能の相関について模討し、䀒触知の意義について考察を加元 てなた。

工対象および方法

对象は由利町出稼告震民96名.本茫・由利地域任民の总林署職員/4 4 名でいずれも目鸴症状(一)、視診に黄㾝(の者である。採血による䀒機能 㭘㚗はGOT。GPT及心゙Al一Pである。なお䀒触知は被模者を仰卧位 にし行ったが、被㭘者の体型、睗内がスの有無、腹壁の硬吉、診察医の熟 練の程度むどの要素で大きく左石され るので、朝食は普通にして。午前中行 表I。旰触知類度 一同一医師によって馀繁を行い方乳 像上横指上表现した。

正成績

1)肝触知の頻度: 表1のごとく旰触知 (けが $75 \%$ ．䀒触知(け)は全体で 24 。 $9 \%$ であった。年代別の䛲触知は年代 が進むに徒って高率となり.60代で は $40 \%$ 示した。なおこ斿の触知 された䀒はいずれも平滑瑱であった。 肝触知は体型によって左后さ几肥满度 で梌討してみると、䀒触知(十)は世型 が $3 \%$ と多く、盵满型か１5\%と少 的った。

2)旰触知上旰機能検查: 表了のごとく 䀒機能湌㚗成樍は表2の基準によって $A ， B ， C ， D$ 群の4 群に区分した。 GO丁について旰けを見るとA群が8 O. $5 \%$.B，C群 $53 \%$.D群 86 . $5 \%$ を示し. 3 横指触知士几たもの でもA群が2名.D群が○となってい る。GPTにおいては旰けではA群7 6. $8 \%$ 。四群 $80 \%$ を示しA群より

\begin{tabular}{|c|c|c|c|c|c|c|}
\hline \multirow[b]{2}{*}{ 年代 } & \multirow[b]{2}{*}{ 例数 } & \multirow{2}{*}{ 肝触知(-) } & \multicolumn{2}{|c|}{ 肝 } & 知 $(T)$ & \multirow[b]{2}{*}{ AF (H) 計 } \\
\hline & & & 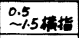 & 2 粸指 & 3榙指 & \\
\hline$\sim 30$ & 46 & $40(87.0)$ & $2\left(x_{3}\right)$ & $4(8.7)$ & 0 & $6(13.0)$ \\
\hline 40 & 94 & $70(74.5)$ & $8(8.5)$ & $10(10.6)$ & $6(6.4)$ & 24 (25.5) \\
\hline 50 & 68 & $50(73.5)$ & $9(3.2)$ & $5(68)$ & $4(5.9)$ & $18 \quad(265)$ \\
\hline 60 & 25 & $15(60.0)$ & $4(66.0)$ & $6(24,0)$ & 0 & $10(40.0)$ \\
\hline 計 & 233 & $175(75.1)$ & $23(9.9)$ & $25(0.7)$ & $10(4.3)$ & $58(24,1)$ \\
\hline
\end{tabular}

表 2. 判 定 盤

\begin{tabular}{|c|c|c|c|c|}
\hline & $A$ & $B$ & $C$ & $D$ \\
\hline$G O T$ & $5 \sim 34$ & $35 \sim 39$ & $40 \sim 44$ & 45 以上 \\
GPT & $8 \sim 34$ & $35 \sim 39$ & $40 \sim 44$ & 45 以上 \\
Al-P & 3.9 以下 & $4.0 \sim 4.9$ & $5.0 \sim 5.9$ & 6.0 以上 \\
\hline
\end{tabular}

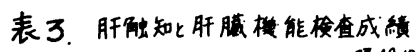

\begin{tabular}{|c|c|c|c|c|c|c|}
\hline \multirow{2}{*}{\multicolumn{2}{|c|}{ 分 }} & \multirow[b]{2}{*}{ 例数 } & \multirow[b]{2}{*}{ 旰解如(-) } & \multirow{2}{*}{\multicolumn{3}{|c|}{ 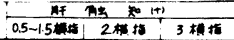 }} \\
\hline & & & & & & \\
\hline \multirow{4}{*}{$\begin{array}{l}G \\
0 \\
T\end{array}$} & A & 178 & $143(80.5)$ & $19(10.6)$ & $14(7.8)$ & $2(1.1)$ \\
\hline & $B, C$ & 32 & $17(53.1)$ & $3(94)$ & $9(28.1)$ & $3(9.4)$ \\
\hline & D & 22 & $19(86.5)$ & $1(4.5)$ & $2(9.0)$ & 0 \\
\hline & F. & & $32.8( \pm 24.5)$ & $328( \pm 24,5)$ & $31.1 \pm 7.6)$ & $34.3( \pm 19.1)$ \\
\hline \multirow{4}{*}{$\begin{array}{l}G \\
p \\
T\end{array}$} & $A$ & 219 & 16 & $22(10.0)$ & $24(10.9)$ & $5(2.3)$ \\
\hline & $B, C$ & 3 & $2(6.7)$ & 0 & $I(333)$ & 0 \\
\hline & D & 10 & o) & $1(100)$ & $1(10.0)$ & 0 \\
\hline & 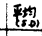 & & 2) & $16.9( \pm 8.6)$ & $184(16.3)$ & $16.0(t+2)$ \\
\hline \multirow{4}{*}{$\begin{array}{l}A \\
\stackrel{f}{p} \\
p\end{array}$} & A & 191 & $150(78.5)$ & $20(10.5)$ & $16(8.4)$ & $5(26)$ \\
\hline & $\mathrm{B}, \mathrm{C}$ & 34 & $27(79.4)$ & $1(2.9)$ & $6(12.6)$ & 0 \\
\hline & $D$ & 7 & $2(285)$ & $2(28.6)$ & $3(429)$ & 0 \\
\hline & (20.0) & & $283(1+31)$ & $3.01( \pm 1.36)$ & $3.40(\mathrm{k} / \mathrm{k} 2)$ & $270 \times 0.71$ \\
\hline
\end{tabular}


やや高率である。又了横指触知されに5名と ひA群に入っており何う関係が見られなかっ た。Al一Pにあいては肝( ()ではA群。BC 群では79\%を示しているのにD群において は2 $8.5 \%$ と低率を示し. 肝触知 2 横指に おいてはA 一 Pが高值となるに従って触知 する頻度七高くなる。うに思クれる。

3)アルコ一ル饮用と䀒機能梌㚗：表 $4(a \cdot b)$ のごとくアルコ一ル飲用は一時的な飲酒量よ

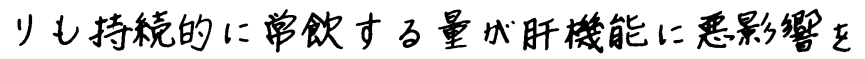
及ほしていることを示している。

4)精密椧㚗結果: 表5の ゙゙とく旰機能梌直B 群C群D群の者 63 名中54名について精密 检㚗を实施したが、表5の結果、治痖を要才 る者25名であった。光のう5肝触知された 者はろ名にす弪なかった。又、表6のごとく 肝了横指触知ミれた5名についての精梌結果 は慢性肝父】例で他は界常はなかった。GO T.GPT/ 100 以上を示した者7名に肝生 㭘、腹朊鏡榆查を实施したがその結果は急性 䀒父1名、慢性旰父6名であり重篤等疾患は 発見されなかった。

III結び

急性肝や慢性肝炎の增恶期のものは採血に よるGOT.GPTの柃查で大变良くスクリ 一ニングされる。しかし脂肪肝、䀒硬变、䀒 癌などでは、䀒機能检㚗は軽度の異常か、正 常值を示すことが少なくない。光こでンれう の疾患の決定に当っては最終的には腹腹鏡㭘

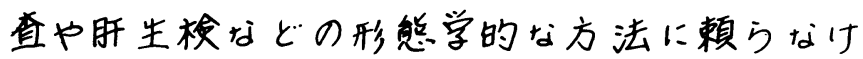
ればなうず。䀒疾患の形態学的なアプロ一千 の最も基本的な手段である旰能知を集検の埸 に持ら込むことは、機能的なアプローチをプ うスするものであると考えられる。今回，対 象者も少なく重第な疾患が僬見できなかった

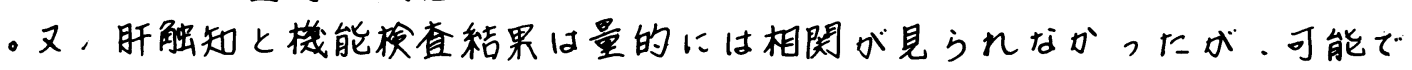
あへば旰触知にあわせて機能梌亘を实施することが好むしいと思へれる。
表4. アルコールと肝機能栺查

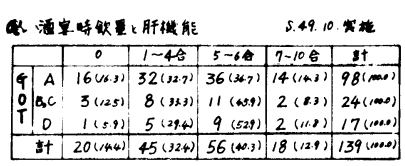

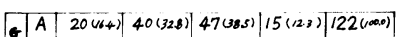

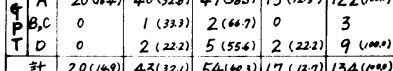

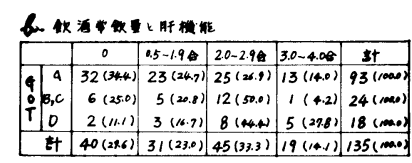

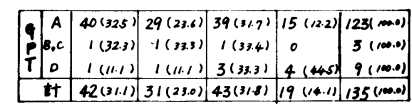

表5、精密検診結果

表6. 肝了㭋指触知され下: 6の

\begin{tabular}{|c|c|c|c|c|c|c|c|}
\hline 41 & GOT & GPT & 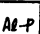 & $17 \times$ & trans & $2 x$ & 佔* \\
\hline $56 x$ & 49 & 24 & 3.8 & 50 & 16 & 26 & ritemen \\
\hline 40 & 30 & 14 & 2.3 & 10 & 3 & 20 & \\
\hline 46 & 39 & 14 & 2.7 & 5 & 2 & 35 & - \\
\hline 47 & 30 & 12 & 1.7 & 5 & 3 & 30 & - \\
\hline 56 & 39 & 16 & 3.2 & & & & \\
\hline
\end{tabular}

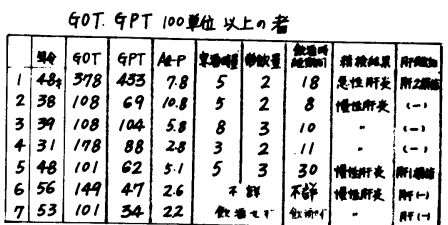

\begin{tabular}{|c|c|c|c|c|}
\hline & 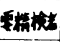 & \multicolumn{2}{|c|}{ 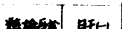 } & 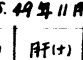 \\
\hline$B$ & 30 & 28 & 23 & 5 \\
\hline$c$ & 10 & 3 & 3 & 0 \\
\hline$D$ & 23 & 23 & 18 & 5 \\
\hline 計 & 63 & 5485.7 & 44 & 10 \\
\hline \multicolumn{5}{|c|}{ 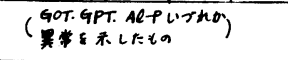 } \\
\hline & & 㣜数 & \multicolumn{2}{|c|}{ 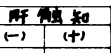 } \\
\hline & 时暳 & 1 & 0 & 1 \\
\hline & 涀娄 & 13 & 12 & 1 \\
\hline & 6变 & 1 & 1 & 0 \\
\hline & 才肝 & 1 & 1 & 0 \\
\hline & 3艾 & 2 & 2 & 0 \\
\hline & 事病 & 7 & 7 & 1 \\
\hline & 8 & 28 & 25 & 3 \\
\hline
\end{tabular}


422.肝疾患飞おけるモノアミンオキシタ一ゼ値飞関して

○星野弘驾, 大西康, 行木紘一, 酒井健次 (茨城県土浦協同病院)

肝疾患特飞肝硬変症飞おいて, 血中モノアミンオキシダ一ゼ(MAO) が異常値を示すととに関しては数多くの報告がなされており，現在 M A O が肝の線維化を示す酵素として, 重要な検査であるといわれ, 肝生検組織との相関性など多数の報告がみられる。今回，われわれは MA ○が肝の線維化飞関してどの程度の信頼性があるのか，腹腔鏡， 肝生検飞て診断のついた症例を対象飞, 肝硬変症, 慢性活動性肝炎, ウイルス性肝资の急性期患者飞ついて，MAO值を測定した。しかし ながら，慢性活動性肝咨と肝硬変症との間には差異をみとめず，をた M A O 值の経時的変動を追う飞, 特飞肝硬変症患者において MA 0 値 の変動が激しかつた。この点に関し, 検討してみたい。

\section{(対象)}

肝硬変症では腹柾鏡にて確定診断のついた24例を対象とした。その うち 12 例飞関して入院時及び外来での経時的変動を追求した。慢性活 動性肝炎では肝生検（腹䤚鏡下）飞て診断のついた12例及び1年前よ り生検にて慢性活動性肝炎として経過観察中の 4 例計16 例を対象とし た。又，ステロイドホルモン使用例を除いた几例に関して経時的変動 を追求した。又ウイルス性肝炎は，トランスアミラーゼ高值の9 例を 対象とし，その経時的変動を追求した。（表1，2）

(検查方法)

測定は, M c E w e u b 方法飞従い, 単位は血清 $1 \mathrm{ml}$ あたり $37^{\circ} \mathrm{C} I$ 時間内 $R$ b enzylamineより生成されるbenzaldehyde 量をる つて表わし，てれを】単位としている。

( 結語 )

1）血中 M A O 值を入院時測定してみると，肝硬変症及び慢性活動 性肝炎では正常飞比し高值であつたが, 両者に差異はみとめなかつた

2) 又両疾患飞関して M A O 值の経時的変動を週毎に追うに特に肝 硬変症において M A O 值の変動が激しかつた。又その変動に一定の方 向性をみとめなかった。

3）各種疾患飞おくてと一G T P の相関性を検討したか両者に相 関性をみとめな加つた。

4) 以上ょり正常例やウィルス性肝咨の急性期と比べて慢性活動性 肝资や肝硬変症において明らかに M A O 值が高値を示す症例が多い点 を考えると肝の線維化にMAOが関与しているるのと考えられる。 
5）しかし，MAO值の変動がはげしいととを考え合わせる一回の 測定値にて判断するととは M A O 值が高値の場合では意味があると思 われるが正常值や低值の場合には問題があり，やはり経時的飞数回の 測定にて意味があるように思われる。

表 1 A 所确変应

\begin{tabular}{|c|c|c|c|c|c|c|c|}
\hline . & Name & Sex & cholest & $A I-P$ & $\gamma \mathrm{GTP}$ & MAO & $\begin{array}{l}\text { Lapa } \\
\text { の有無 }\end{array}$ \\
\hline 1 & $\mid$ 久O & $\hat{o}$ & 235 & 14.3 & 740 & 41.6 & 0 \\
\hline 2 & 坂 0 & $\hat{\delta}$ & 175 & 19.3 & 456 & 31.2 & 0 \\
\hline 3 & 頁O 郎 & $\hat{o}$ & 174 & 18.6 & 97 & 58.5 & 0 \\
\hline 4 & 180 है & 우 & 164 & 10.3 & 98 & 39.2 & 0 \\
\hline 5 & $M O$ 方 & o & 92 & 7.6 & 98 & 66.5 & 0 \\
\hline 6 & 小O $\div 0$ & $\hat{\delta}$ & 203 & 14.4 & 318 & 47.7 & 3 \\
\hline 7 & 武○ 改 & ๙ & 193 & 7.0 & 93 & 14.7 & 0 \\
\hline 8 & 平○ * & $\delta$ & 170 & 21.8 & 51 & 91.0 & 0 \\
\hline 9 & 河O $\equiv 0$ & $\hat{\delta}$ & 109 & 9.9 & 403 & 47.3 & 0 \\
\hline 10 & $\equiv 0$ & t & 220 & 11.1 & 291 & 16.9 & 0 \\
\hline 11 & 大○ 長O郎 & $\hat{\jmath}$ & 199 & 46.4 & 415 & 17.3 & 0 \\
\hline 12 & 小 0 & $\hat{\delta}$ & 195 & 17.4 & 336 & 67.5 & 0 \\
\hline 13 & 久○田 ○司 & $\hat{\delta}$ & 00 & 18.6 & 169 & 54.6 & 0 \\
\hline 14 & 村○ 春 ○ & $\hat{\jmath}$ & 341 & 31.0 & 227 & 38.3 & 0 \\
\hline 15 & 神○克 ○ & ิิ & 196 & 12.8 & 99 & 42.6 & 0 \\
\hline 16 & 鎜O 高 & $\hat{\delta}$ & 194 & 8.9 & 74 & 42.5 & 0 \\
\hline 17 & $\mid \begin{array}{lll}1+0 & \text { s. }\end{array}$ & ㅇ & 158 & 10.0 & 20 & 37.7 & 0 \\
\hline 18 & 中 0 2 $\quad 0$ & q & 174 & 13.0 & 27 & 41.5 & 0 \\
\hline 19 & | & ㅇ & 182 & 13.3 & 83 & 65.0 & 0 \\
\hline 20 & 菊○膦 0 & $\hat{\jmath}$ & 138 & 6.8 & 25 & 33.8 & 0 \\
\hline 21 & 脍O 正 $O$ & $\hat{\delta}$ & 121 & 14.1 & 200 & 44.3 & 0 \\
\hline 22 & 宧 & 우 & 152 & 8.0 & 29.3 & 42.0 & 0 \\
\hline 23 & 坪O & $\hat{\delta}$ & 18 & 14.7 & 44 & $\begin{array}{l}36.8 \\
\end{array}$ & 0 \\
\hline 24 & 桂O to 0 & fo & 161 & 11.6 & 149 & 39.8 & 0 \\
\hline
\end{tabular}

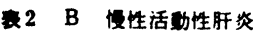

\begin{tabular}{|c|c|c|c|c|c|c|}
\hline $\mathrm{No}$ & Name & Sex & Al-P & $\gamma$ GTP & MAO & Lapa \\
\hline 1 & 岡O & $\hat{\sigma}$ & 42.0 & 116.0 & 39.7 & 0 \\
\hline 2 & 会○ 紀 0 & $\hat{o}$ & 10.4 & 83.5 & 59.5 & 0 \\
\hline 3 & 田O さ 0 & $q$ & 9.9 & 63.0 & 46.7 & 0 \\
\hline 4 & 黑O 0 & $\delta$ & 21.9 & 755.0 & 60.5 & 0 \\
\hline 5 & 大O 汉 & $\hat{\jmath}$ & 9.5 & 217.0 & 43.5 & 0 \\
\hline 6 & 村○ 上Оの & q & 10.2 & 9.8 & 30.1 & 0 \\
\hline 7 & 岩 0 & $\hat{\delta}$ & 7.2 & 153.0 & 26.8 & $x$ \\
\hline 8 & tO & $q$ & 11.6 & 58.6 & 55.0 & 0 \\
\hline 9 & 岡 0 夏 & $\hat{\delta}$ & 11.8 & 70.0 & 27.7 & 0 \\
\hline 10 & 大O 長O郎 & $\hat{\delta}$ & 12.6 & 29.4 & 26.9 & 0 \\
\hline 11 & 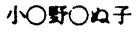 & $q$ & 9.2 & 109.0 & 38.3 & $x$ \\
\hline 12 & 蔡 0 & $\hat{\delta}$ & 11.6 & 57.0 & 31.0 & $x$ \\
\hline 13 & 岡 0 & $\hat{\delta}$ & 7.5 & & 51.5 & $x$ \\
\hline 14 & 杰O 0 & $\hat{\delta}$ & 8.2 & 78.0 & 50.0 & 0 \\
\hline 15 & 小O 0 & $\hat{\jmath}$ & 7.8 & 78.0 & 36.8 & 0 \\
\hline 16 & 中 $0 \tau 0$ & 우 & 14.5 & 82.0 & 36.8 & 0 \\
\hline
\end{tabular}

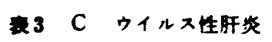

\begin{tabular}{|c|c|c|c|c|c|c|c|}
\hline Na. & Name & Sex & GOT & $\overline{G P T}$ & Al-P & $\gamma$ GTP & $\overline{\mathrm{MAO}}$ \\
\hline 1 & 柴O 桂O & ㅇ & 770 & 630 & 15.8 & 21 & 19.7 \\
\hline 2 & 市O & $\hat{\jmath}$ & 650 & 570 & 14.2 & 79 & 26.4 \\
\hline 3 & 河O 邦O & ริ & 260 & 190 & 14.1 & 250 & 41.0 \\
\hline 4 & $=0$ & $\jmath$ & 620 & 820 & 13.4 & 132 & 25. \\
\hline 5 & 粭O 㮃O & 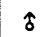 & 740 & 490 & 22 & 252 & 31. \\
\hline 6 & 传O间O & $\hat{\delta}$ & 210 & 320 & 15.5 & 44 & 29.8 \\
\hline 7 & RO & f & 600 & 160 & 11.3 & 191 & 29.8 \\
\hline 8 & 平 & $\delta$ & 520 & 490 & 18.0 & 47 & 18.1 \\
\hline 9 & 触○た○子 & ㅇ & 120 & 370 & 17.9 & 44 & 19.7 \\
\hline
\end{tabular}

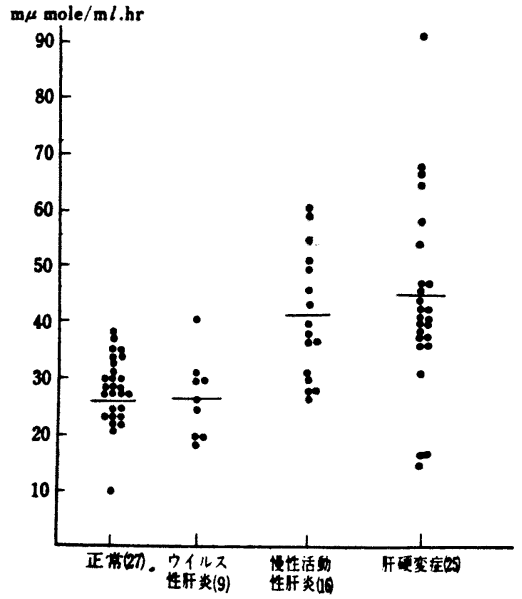

图 1 正常及び各種肝疾患の MAO 值

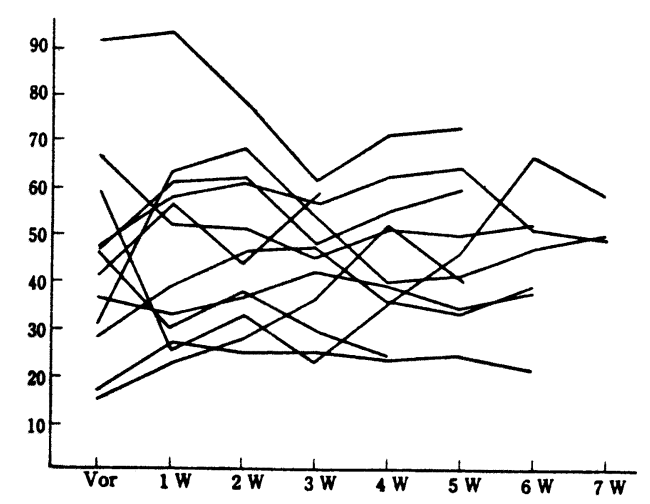

图 2 肝硬変症患者の $\mathrm{MAO}$ の变動

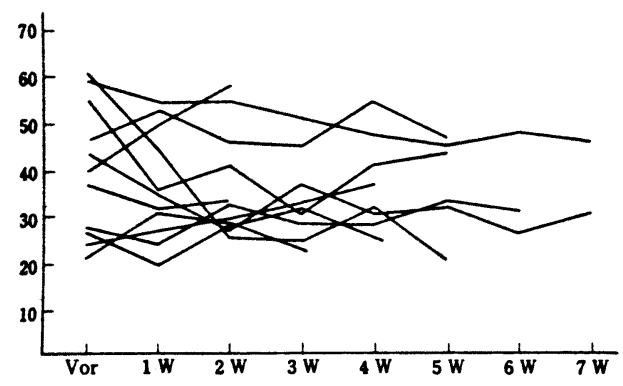

図 3 惯性活動性肝资の MAO の変動

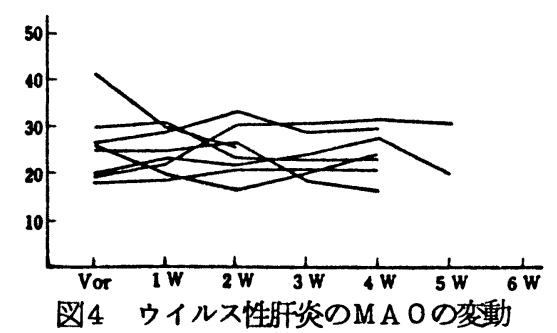




\section{3.最近5年間に入院した旰疿患患者の実態}

広島具厚生連尾道総合病院科

○光波康壮，国政微明，后井直文，石田邦夫 野口章男，盛生宏一，小先誠也

〔锗言〕最近5年間に入院した旰疾患々者403例の害態について，特に鹿 民の患者々他の䎳業の患者との比較を試みる目的で，以下の4 群以分けて

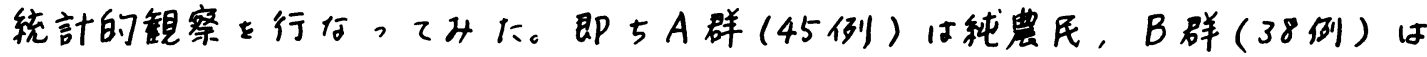
家業メ゙典家であるが患者は他䎳業、徒事しているも9，C群(17/例)は

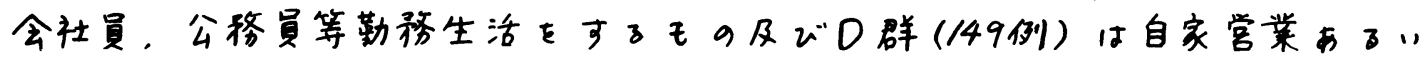
は晨家以外の主嫜を含无ものである。

[症例の分析]

1) 年令分布は表1に示す如くA群は他群に比

し，高手令層がゃ，多い。

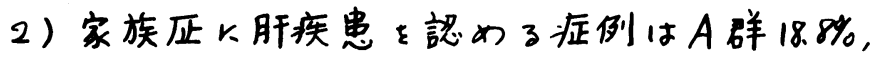

B群 $11.1 \%$ ，C群 $11.3 \%$ ，D群 $20.8 \% \times A ， D$ 群で高 率で西了。

3) 1 日3合以上a飲酒在有する频度

\begin{tabular}{|c|c|c|c|c|}
\cline { 2 - 4 } \multicolumn{1}{c|}{1} & $A$ & $B$ & $C$ & $D$ \\
\hline$\sim 20 \chi$ & $0 \%$ & $5.3 \%$ & $0 \%$ & $4.0 \%$ \\
\hline$\sim 40 \star$ & $7.0 \%$ & $18.4 \%$ & $40.9 \%$ & $28.9 \%$ \\
\hline$\sim 60 \chi$ & $44.2 \%$ & $52.6 \%$ & $54.2 \%$ & $38.3 \%$ \\
\hline $60 \star \sim$ & $48.8 \%$ & $23.7 \%$ & $7.6 \%$ & $28.9 \%$ \\
\hline
\end{tabular}

を男女别にみると，女性ではD群に1例 万るのムであるが。男性ではA群 $44.4 \%$ ， B群 $24.1 \%$ ，C群 $33.1 \% ， D$ 群 $39.7 \% \times A ， D$ 群以ゃ>高率である。

4) HB抗原a検出率には各群a間以有 意の差は認められはい。

5)合併症の種類，頻度は表2 r示す如 くである。即5合併症飞有する頻度は $A$

\begin{tabular}{|c|c|c|c|c|}
\hline 表 2 & $A$ & $B$ & C & D \\
\hline 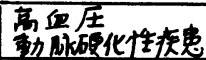 & $4.4 \%$ & $105 \%$ & $1.2 \%$ & $6.0 \%$ \\
\hline 糖尿病 & $22.2 \%$ & $10.5 \%$ & $6.4 \%$ & $8.7 \%$ \\
\hline 溃㿋性疾患 & $0 \%$ & $7.9 \%$ & $4.1 \%$ & $3.4 \%$ \\
\hline 胆のう疾患 & $6.7 \%$ & $2.6 \%$ & $2.3 \%$ & $0.7 \%$ \\
\hline その他 & $2.2 \%$ & $2.6 \%$ & $1.2 \%$ & $4.0 \%$ \\
\hline 計 & $35.6 \%$ & $34.2 \%$ & $15.2 \%$ & $16.1 \%$ \\
\hline
\end{tabular}
$B$ 群で高率であるが，予期以反し，A 群で糖症病合併例が多く，漟痛合併例が少ふい。

【肝疾患a病態a検討〕 1) $A$ 群45例， B 群38例， C 群 171 例，D群149例計403 例飞診断别以分けると表了に 示す如く，A群では他群に比 し旰硬变症が多く，逆以急性 肝炎が少你く，脂肪肝は|例 毛諰わ5れ你い。群はC群。

\begin{tabular}{|c|c|c|c|c|c|}
\cline { 2 - 6 } \multicolumn{1}{c|}{} & $A$ & $B$ & $C$ & $D$ & $\overline{1}$ \\
\hline 急性肝炎 & $3(6.7)$ & $6(15.8)$ & $42(24.6)$ & $37(24.8)$ & 88 \\
\hline 慢性肝炎 & $15(33.3)$ & $19(50.0)$ & $72(42.1)$ & $39(26.2)$ & 145 \\
\hline 肝硬变症 & $21(46.7)$ & $10(26.3)$ & $44(25.7)$ & $51(34.2)$ & 126 \\
\hline 原発任肝癌 & $6(13.3)$ & $2(5.3)$ & $8(4.7)$ & $2 /(14.1)$ & 37 \\
\hline 脂肪肝 & $0(0)$ & $1(2.6)$ & $5(2.9)$ & $1(0.7)$ & 7 \\
\hline 言十 & 45 & 38 & 171 & 149 & 403 \\
\hline
\end{tabular}
D群とほっ゙同様である。

2)次に入院した各群にかける旰疾急の重症度をみる目的で，次の了点に 
$つ い て$ 比較した。

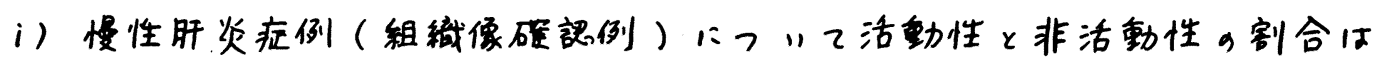

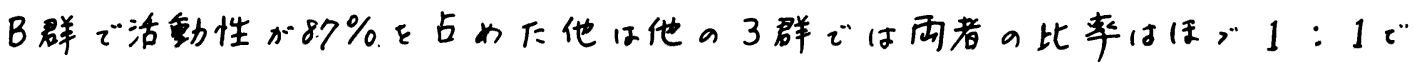
あ 3 。

ii）旰硬变症9症例を代僖性と非代㑽性に分け乙との制合にみると，非

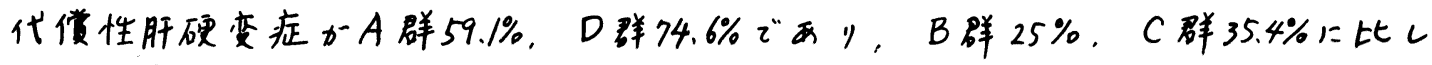
有意以高率である。

iii）死亡例1 0 A群 $22.2 \%$ ，D群 $18.8 \%$ ，B群 $5.3 \% ， C$ 群 $4.6 \%$ 、师的多く、A 群か最も高い。

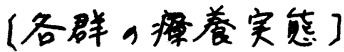

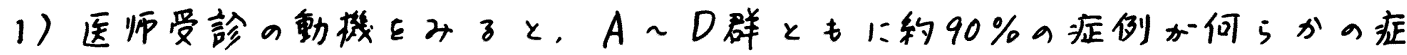
状を新之乙医师を訪れているが，B，C，D群はともに牨5\%が模診で肝

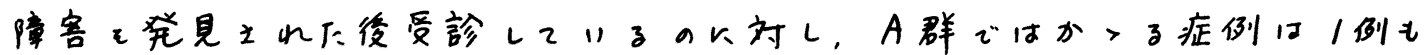

12 1).

2)在状笔现後医师受診までの期間を 慢性肝疾患例飞ついて検討してみると 表4 , 如く，䄪8 $80 \%$ 1症状発理後 1 力

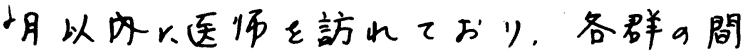
に差は标く，6力月以上放置し2

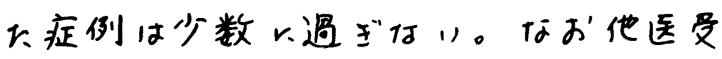
診復当科飞訪れた毛 9，当科的直接受 診し下もの、比は4群ともにはづ

$1: 1$ であ 3 .

3）死亡例に除く症例につ”乙长の 退院理由をみると。表 5 に示す如く C，D群はA，B群に比し軽快後退 院してものが多く，A群は他群に比 し，整快し何”ま>中途希望退院し た症例が多い。

4）更以退院後a受診状况\&4段階 即与全く受診し1う”斗の，不良(急 性肝炎では 2 回曼診，慢性疾患 ではカ目間程度受診)，良(急性 旰炎では3力月，慢性疾患では3 症扰焐理後受診期間（）\%

\begin{tabular}{|c|c|c|c|c|}
\cline { 2 - 5 } \multicolumn{1}{c|}{ 表4 } & $A$ & $B$ & $C$ & $D$ \\
\hline$\sim$ 1力月 & $28(80.0)$ & $24(75.6)$ & $91(79.8)$ & $74(75.5)$ \\
\hline$\sim 3$ 力月 & $4(11.4)$ & $5(15.6)$ & $13(11.4)$ & $14(14.3)$ \\
\hline$\sim 6$ 加 & $2(5.7)$ & $1(3.1)$ & $1(0.9)$ & $5(5.1)$ \\
\hline 6力月 & $1(2.9)$ & $2(6.3)$ & $9(7.9)$ & $5(5.1)$ \\
\hline & 35 & 32 & 114 & 98 \\
\hline
\end{tabular}

退院理由(1)\%

\begin{tabular}{|c|c|c|c|c|}
\cline { 2 - 5 } \multicolumn{1}{c|}{5} & $A$ & $B$ & $C$ & $D$ \\
\hline 整快 & $25(71.4)$ & $26(72.2)$ & $133(82.1)$ & $104(86.0)$ \\
\hline 希望 & $6(17.1)$ & $2(5.6)$ & $15(9.3)$ & $10(8.3)$ \\
\hline 検查終了 & $4(11.4)$ & $8(22.2)$ & $14(8.6)$ & $7(5.7)$ \\
\hline & 35 & 36 & 162 & 121 \\
\hline
\end{tabular}

退院後受診状况（）\%

\begin{tabular}{|c|c|c|c|c|c|}
\hline 表 6 & 受診㣙 & 不良 & 良 & 䃼医 & \\
\hline$A$ & $6(17.1)$ & $4(11.4)$ & $18(57.4)$ & $7(20.0)$ & 35 \\
\hline$B$ & $2(5.6)$ & $4(11.1)$ & $24(66.7)$ & $6(16.7)$ & 36 \\
\hline$C$ & $17(10.5)$ & $14(8.6)$ & $103(63.6)$ & $28(17.3)$ & 162 \\
\hline$D$ & $14(11.6)$ & $6(5.0)$ & $84(69.4)$ & $17(14.0)$ & 121 \\
\hline
\end{tabular}

6力月以上受診)，较医以分け乙比䑤すると表6に示す如くA群に他群に 比し，全く受診し佂“か或は不良の症例がゃ〉多い。

[要約]入院肝疾患飞4群以分けて検討したが，A群はや、高令者が多く 肝硬变症が多く、かっ重症例が多い, 更、A 群では検診により発見され

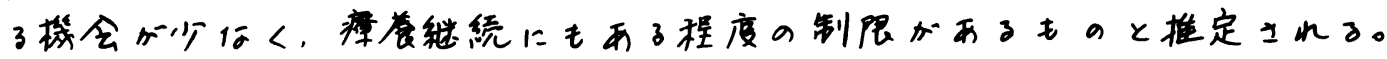


424。土浦市周辺の胆石症の病像

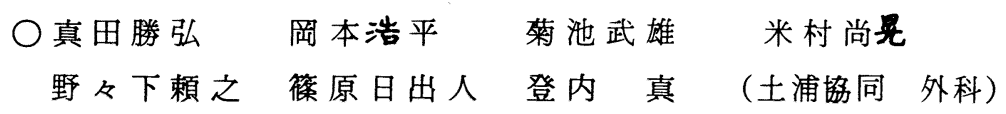

（緒言）欧米人と日本人の胆石症を比較する と, 欧米人ではコレステロ一ル系胆石, 胆襄内 胆石が多く，まを女性に多的に対し，日本人 ではビリルビン采胆石，胆管内胆石が多く，男 性飞比較的多いのが特改であるとされてをた。 しかし，生活様式や食物の変化などから日本人 の胆石子大都市加占先飞漸時欧米人の胆石症飞 近づている。昭和30年台飞は，大都市，中都 市，農村地区飞 3 大別するとその傾向飞明ら加 な差があり,いわば胆石症の進化の程度が地域 的飞現われるよう飞なつた。最近ではこの傾向 は農村地带でるますます進んできていると考え られている。われわれは昭和 44 年 4 月から昭和 表一1年令上性

\begin{tabular}{|r|r|r|r|}
\hline 年令 & 男 & 女 & 計 \\
\hline $20 \sim$ & 3 & 9 & 12 \\
$30 \sim$ & 12 & 33 & 45 \\
$40 \sim$ & 19 & 38 & 57 \\
$50 \sim$ & 20 & 54 & 74 \\
$60 \sim$ & 23 & 37 & 60 \\
$70 \sim$ & 6 & 3 & 9 \\
$80 \sim$ & & 2 & 2 \\
\hline 言十 & 83 & 176 & 259 \\
\hline
\end{tabular}
50 年 5 月までの間飞土浦協同病院で259例の胆 石症の手術を経験した。土浦市は東京に近い地方都市で, 周辺飞農村 地带を控えているという地理的条件にあるが，ての地域における最近 の胆石症の病像はどら加，われわれの症例办ら检討した。

(成績) 年令別, 性別飞みた症例の内訳を表一几に示した。50才台加 最子多く，60才台，40才台がてれ飞繶いて多加つた。男女比は1：2.12

表一2 胆石の種類

\begin{tabular}{|r|r|r|r|}
\hline & J系石 & ビ系石 & その他 \\
\hline 昭 44 & 8 & 1 & \\
45 & 15 & 2 & \\
46 & 33 & 6 & 2 \\
47 & 45 & 6 & 2 \\
48 & 39 & 5 & 1 \\
49 & 55 & 5 & 2 \\
50 & 26 & 5 & 1 \\
\hline 言十 & 221 & 30 & 8 \\
\hline
\end{tabular}
であつた。一般飞胆石症は30才台, 40 才 台，50才台でピークを形成するといわれ ているが，当院飞おける手術時年令は， 40才台，50才台，60才台でピ一クを形成 していた。従来日本人胆石は男飞多いの が特徵とされたが，昭和 25 年頃から大体 男女同数となり最近は欧米と同じく女性 の方が多くなつているが，1：2.12とい う比は日本では高的方である。次飞胆石。 の種類を表一2に示した。コレステロール 系胆石が85.3\%を占め, ビリルビン系胆 石は11.6\%にすを゙なかつた。

最近の東京飞打ける胆石症でコ菜石82.1 \%, ビ系石17.9\%といら成績があり，わ 
れわれの症例は全く大都会と同様の傾向である。 胆石の種類の変遷の原因として, 脂肪摄取量と回 虫が関与しているとされるが, 土浦市周辺住民の 脂肪摄取量は1日約 $40 \mathrm{~g} て ゙ あ り$, 日本人平均の50 g飞比べてる多くはない。一方回虫卵の検出率は 昭和 37 年には約 $15 \%$ であっが最近数年間は1\% にす達しない程に激減しており, ビ系石の隇少は 回虫の減少が主因であろう。ビ系石の症例だけを とり出して年令分布をみたのが表-3である。60才 台以上ではビ系石がかなりの割合を占めており， これが以前のビ系石優位の名残りである。次に胆

表-3

ビ系石の年令分布

\begin{tabular}{|c|cc|}
\hline 年令 & \multicolumn{2}{|c|}{ 症例数 (\%) } \\
\hline $20 \sim$ & 1 & $(8.3 \%)$ \\
$30 \sim$ & 3 & $(6.7)$ \\
$40 \sim$ & 4 & $(7.0)$ \\
$50 \sim$ & 7 & $(9.5)$ \\
$60 \sim$ & 8 & $(13.3)$ \\
$70 \sim$ & 6 & $(66.7)$ \\
$80-$ & 1 & $(50.0)$ \\
\hline
\end{tabular}
石の所在部位をみると, 表-4に示したでとく,

259 例中胆毫だけ飞あつたるのが200例 ( $77.2 \%)$, 胆管飞る存在して いた症例は59例 (22.8\%)であつた。ての22.8\%という州は高い方では ないが, 症例全体のビ系石の割に

表-4 胆石9 所在部位

\begin{tabular}{|c|c|c|c|}
\hline & 胆费 & 胆事·胆管 & 胆管 \\
\hline 昭 44 & 6 & 1 & 2 \\
\hline 45 & 15 & 1 & 1 \\
\hline 46 & 32 & 2 & 7 \\
\hline 47 & 41 & 7 & 5 \\
\hline 48 & 36 & 5 & 4 \\
\hline 49 & 46 & 6 & 10 \\
\hline 50 & 24 & 6 & 2 \\
\hline \multirow{2}{*}{ 計 } & 200 & 28 & 31 \\
\hline & $77.2 \%$ & \multicolumn{2}{|c|}{$22.8 \%$} \\
\hline
\end{tabular}

表一5 胆管内胆石9程颣

\begin{tabular}{|c|c|c|c|}
\hline & $\beth$ 系石 & ビ系后 & その他 \\
\hline 症例粠 & $\begin{array}{c}35 \\
(59.3 \%)\end{array}$ & $\begin{array}{c}21 \\
(35.6 \%)\end{array}$ & $\begin{array}{c}3 \\
(5.1 \%)\end{array}$ \\
\hline $\begin{array}{l}\text { 全症例 } \\
1 \text { 奶し }\end{array}$ & $13.1 \%$ & $8.1 \%$ & $1.2 \%$ \\
\hline
\end{tabular}
は胆管結石の症例が多いとい充上 う。胆管結石の種類をみると 表-5 よ上うに約 $60 \%$ がコ柔石であ つた。コ系石が胆管で形成される ことはなく，胆管内コ柔石はすべ て胆毫加的兔脱したるのである。 全症例の $13.1 \%$, , 系石症例の 16.7\% が逸脱石という頻度は如 なり高い。

(結满) 土浦市周辺の胆石症 の病像をるると, コ系石が

$85.3 \%$, 男女比が1:2.12とす で全く大都会型を示している 胆石の所在部位は胆管内胆石が

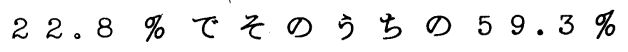
がコ系石で胆衰加らの逸脱石て ある。手術時の所見でる胆豪病 変の高度のものが多办つた。 コレステロ一ル系胆石に上る胆 石症で, 胆毫胆道系の病変の著 明なるのが多いというのが当院 の症例の特改である。 
糖 尿 病

425

蕽村の糖原原健訜

为/砕予偖調查

○成海信雄 浅川春德本肉山沙

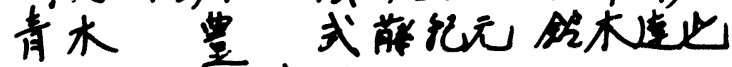

(水户枱首病院)

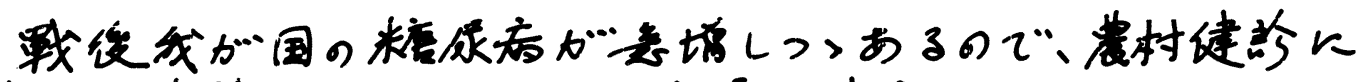

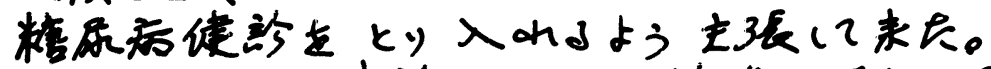

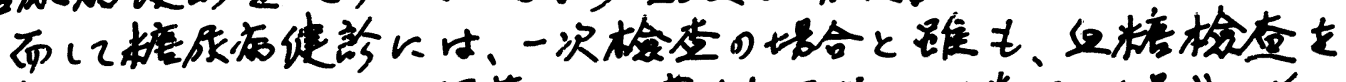

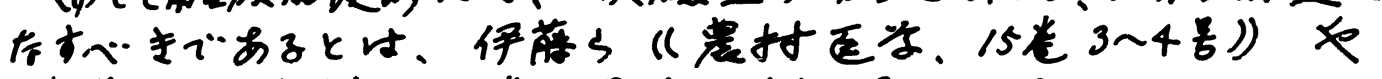

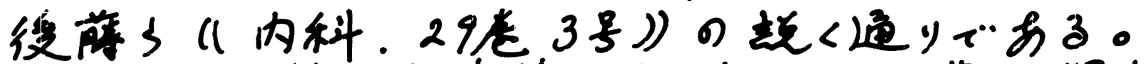

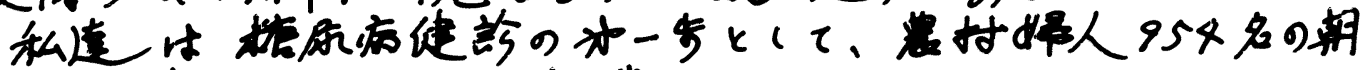

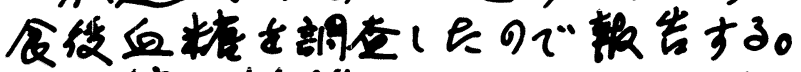

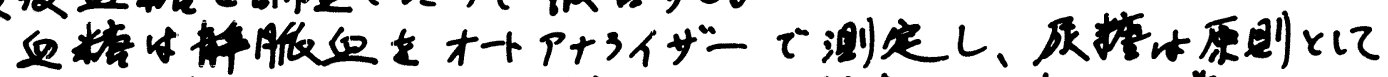

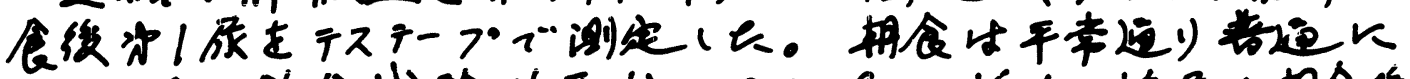

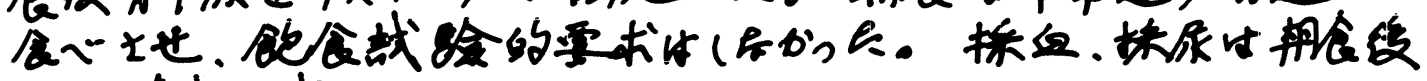

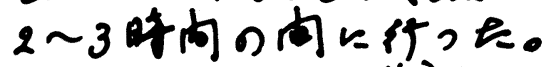

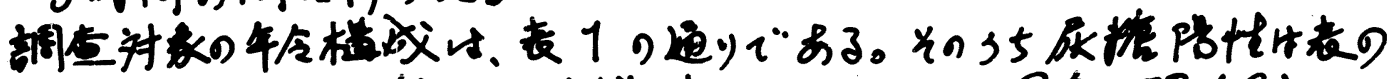

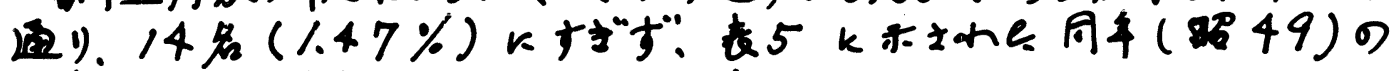

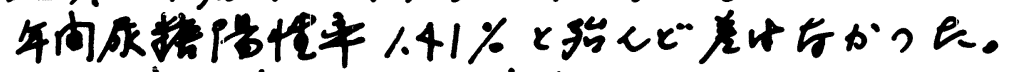

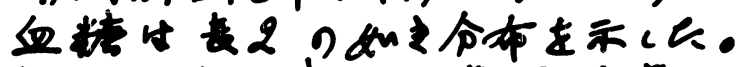

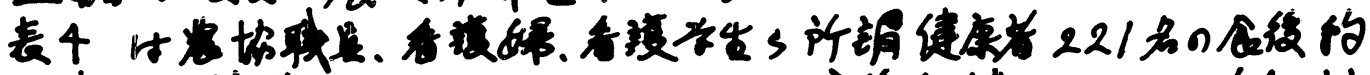

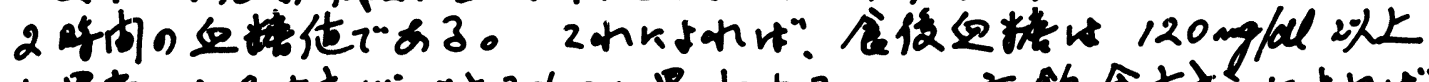

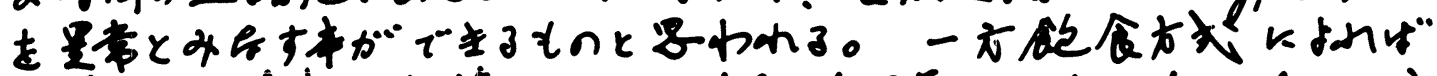

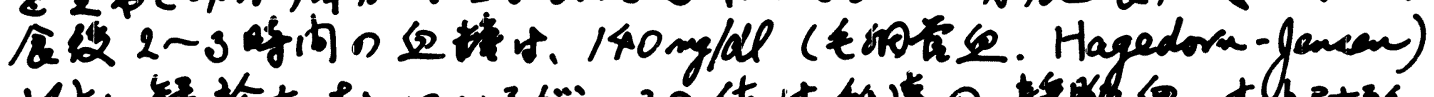

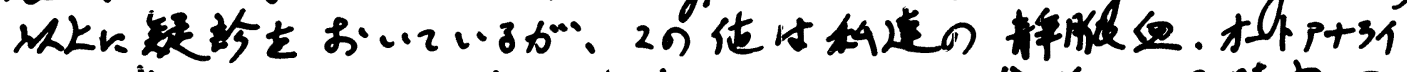

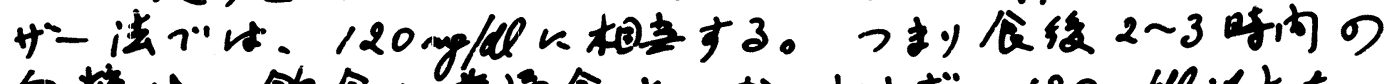

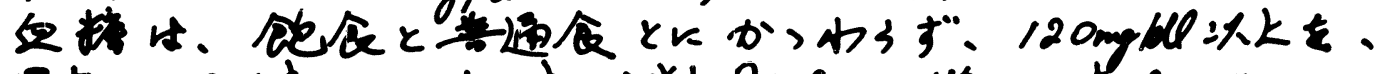

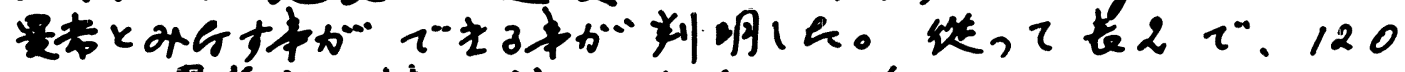

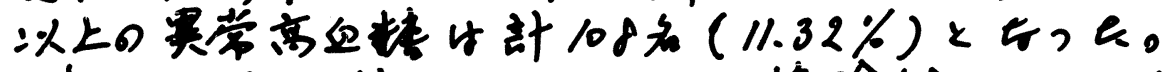

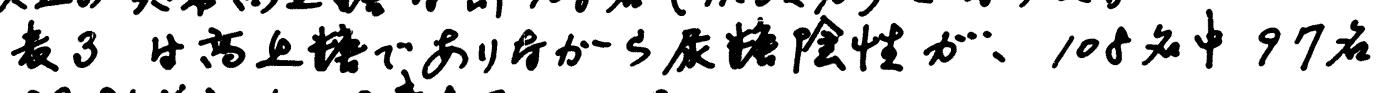
$(89.81 \%)$ t

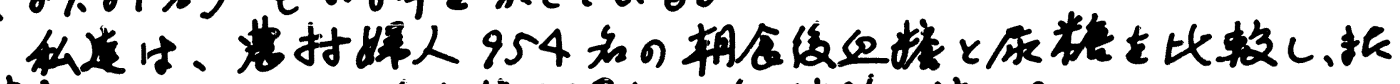

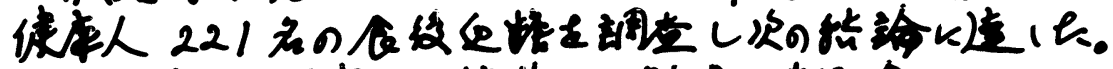

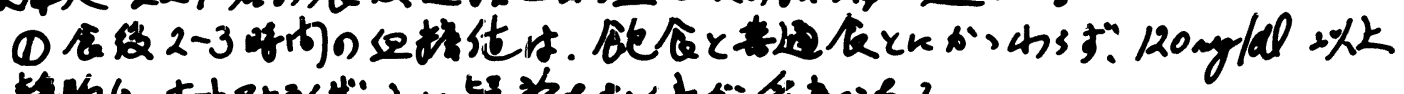

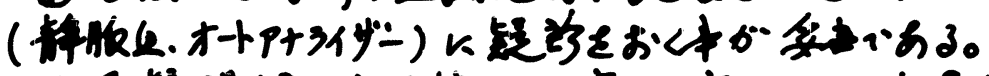

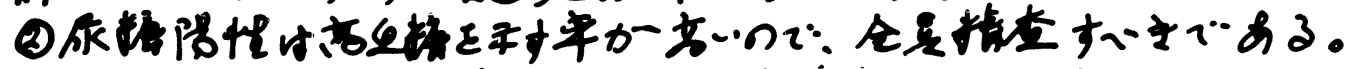

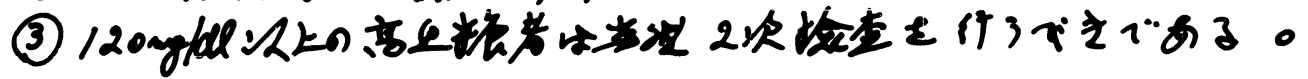


表1 年令棤成と辰糖陽性者表3 尿糖と血焙の闺係

\begin{tabular}{|c|c|c|c|c|c|c|}
\hline 年令 & $20 \sim$ & 30 & 140 & 50 & $60^{\sim}$ & 計 \\
\hline 被榆者 & 13 & 188 & 408 & 288 & 57 & 954 \\
\hline 辰核险住 & 0 & I & 8 & 4 & 1 & 14 \\
\hline
\end{tabular}

\begin{tabular}{|c|c|c|c|}
\hline $\begin{array}{l}\text { 层粮 } \\
(+)\end{array}$ & $\begin{array}{c}(+) \\
\text { 血楼 }\end{array}$ & $\begin{array}{c}(-) \\
\text { 京 }\end{array}$ \\
\hline 例数 & 11 & 3 & 97 \\
\hline
\end{tabular}

表2 血楼價の分布

\begin{tabular}{|c|c|c|}
\hline 血䊏令 & $20 \sim 30 \sim 40 \sim 50 \sim 60 \sim$ & 計 \\
\hline $\begin{array}{l}109 \\
100 \approx \\
110 \approx \\
120 \approx \\
130 \approx \\
140 \approx \\
150 \approx \\
160 \approx \\
170 \approx \\
180 \approx \\
190 \approx \\
200 \approx\end{array}$ & $\begin{array}{ccccc}12 & 130 & 246 & 135 & 21 \\
1 & 35 & 68 & 71 & 15 \\
11 & 54 & 39 & 8 \\
& 8 & 9 & 19 & 6 \\
& 8 & 10 & 4 \\
3 & 8 & 5 & 1 \\
1 & 4 & 2 & 1 \\
& 5 & 3 & 1 \\
& 3 & & \\
& 1 & 1 & \\
& & 2 & \\
& 2 & 1 & \end{array}$ & $\begin{array}{r}544 \\
190 \\
112 \\
42 \\
22 \\
17 \\
8 \\
9 \\
3 \\
2 \\
2 \\
3\end{array}$ \\
\hline 訪十 & 1318840828857 & 954 \\
\hline
\end{tabular}

表4 健康者食後血精

\begin{tabular}{|l|lllll|l|}
\hline & 99 & $100 \sim$ & $110 \sim$ & $120 \sim 130$ & $\overline{1}+$ \\
\hline $10 \sim$ & 38 & 7 & & & 45 \\
$20 \sim$ & 73 & 18 & 4 & & 95 \\
$30 \sim$ & 18 & 16 & 3 & & & 37 \\
$40 \sim$ & 12 & 10 & 6 & 2 & & 30 \\
$50 \sim$ & 3 & 6 & 4 & & & 13 \\
$60 \sim$ & & 1 & & & & 1 \\
\hline $5+$ & 144 & 58 & 17 & 2 & 0 & 221 \\
\hline
\end{tabular}

表53年间の层糖陽性率

\begin{tabular}{|c|r|r|r|}
\hline 年次 & 昭 47 & 昭 48 & 昭 49 \\
\hline 被䬤者 & 5009 & 9262 & $8 / 1 /$ \\
辰糖隄情 & 41 & $7 /$ & $1 / 4$ \\
$\%$ & 0.82 & 0.77 & 1.41 \\
\hline
\end{tabular}


426. 居住地別糖尿病状態の比較検討

高科成良（広島・佐伯病院）

西本幸男（広大・医・二内）

〔緒言〕近年農村の都市化傾向が著しいが, 当地方における都市化のす】 んていない地区,すなわち農村地区（農村群）と広島湾飞接する都市化の す〉んだ地区すなわち準農村地区（準農村群）飞居住する糖疗病患者の状 態を比較検討した。〔対象並びに研究方法〕昭和 47 ・48年に発見された糖 疗病患者（農村群：67例, 準農村群：144例）につを初診時の状態を検討し, 昭和 50 年 4 月末現在, 1 年以上続けて通院治療中の糖尿病患者（農村群： 44 例, 準農村群：155例）について経年観察を行った。さらに農村群おょび 準農村群より無作意に抽出した患者に対し食慨調査を行ら比較検討した。 〔成績〕先ず初診時の状態についてのべる。糖尿病発見の動機（表1)に つレてみると両群とる検診が動機となったるのが多く, 特に農村群では原 爆被爆者健診に上るるのが高率てあった。糖尿病の遺伝関係（表2）ては 準農村群飞遺伝関係を有するるのが多かった。体型（表3）についてみる と瘦せは農村群に多く, $10 \%$ 以上の肥满は準農村群に多かったが, $20 \%$ 以 上の肥满ては両群に差はみられなかった。50gOGTT時IRI反応（表4）飞 ついてみると過剩反応, 正常反応, 低反応, 無反応とる両群の間飞差はな かった。高脂血症の有無（表5）では両群とも高脂血症を呈するすのが過 半数をしめたが, 特に準農村群に多くみられた。眼底変化（表6）につい てみると農村群に網膜症を有するるのが多くみられた。血王についてみる と高血圧は両群とも約 $40 \%$ そられた。また尿蛋白陽性者は両群とも約 40 \%て差はなかった。次に経年観察についてのへる。血糖の推移（表7）に ついて検討すると両群とるコントロール良好なるのが大半をしめているが 不良者は準農村群飞多くみられた。血糖のみについてみると両群とるコン 卜ロール良好なるのが多かったが, 尿糖, 尿蛋白, 高脂血症, 網膜症の推 移を加味して総合的飞糖尿病のコントロール状態（表8）を検討すると良 好なるのは両群とるかなり減少し, 準農村群ては不良者が多くなった。次 飞食慨調査の成績についてのへる。食餌摄取状態（表 9 ）をみると両群と す大半は指示熱量をよく守っている様てあるが, 過剩摄取は農村群に多い 傾向がみられた。蛋白質, 脂肪, 含水炭素平均摄取量（表10）を比較する と両群の間に差はなかった。〔結語〕農村並びに準農村に居住する糖尿病 患者の病態調査おょび経年観察を行い, 環境要素特に食慨氏起因すると思 われる差異が多少みられたが, 食餌調查の結果両者の間飞差はみられず, ての点につをさらに追求する必要を感じた。 
表 1 糖㽷病発見の動機

\begin{tabular}{|c|c|c|c|c|c|c|}
\hline & 検 & 診 & \multirow{2}{*}{ 紹 介 } & \multirow{2}{*}{ 自覚症 } & \multirow{2}{*}{$\begin{array}{l}\text { 他疾患 } \\
\text { 受診時 }\end{array}$} & \multirow{2}{*}{ 計 } \\
\hline & 原 爆* & その他 & & & & \\
\hline 農 村 群 & $\begin{array}{c}24(35.9) \\
31\end{array}$ & $7^{7(10.4)}$ & $14(20.9)$ & $8\left(\begin{array}{ll}1 & 1.9)\end{array}\right.$ & $14(20.9)$ & $67\left(\begin{array}{lll}1 & 0 & 0\end{array}\right)$ \\
\hline 準 農 村群 & $\begin{array}{r}40(27.8) \\
51\end{array}$ & $11(7.6)$ & $38(26.4)$ & $32(22.2)$ & $23(16.0)$ & $144(100)$ \\
\hline
\end{tabular}

* 原爆被爆者健康猃断

(\%)

表 2 糖尿病の遺伝関係

\begin{tabular}{|l|rc|rc|r|}
\cline { 2 - 5 } \multicolumn{1}{c|}{} & な $し$ & あ & \multicolumn{1}{|c|}{ 計 } \\
\hline 農 村 群 & $61(91.0)$ & $6(9.0)$ & $67(100)$ \\
\hline 準農 村群 & $116(80.6)$ & $28(19.4)$ & $114(100)$ \\
\hline
\end{tabular}

表 3 体型

\begin{tabular}{|c|c|c|c|c|c|c|}
\hline & p & せ & \multirow{2}{*}{ 標準体重 } & 肥 & 满 & \multirow{2}{*}{ 計 } \\
\hline & $20 \%$ 以下 & $19 \sim 10 \%$ & & $10 \sim 19 \%$ & $20 \%$ 以上 & \\
\hline 農 村 群 & \multicolumn{2}{|c|}{$\begin{array}{ll}5 & (7.5) \\
13(19.4) & (11.9) \\
\end{array}$} & $28(41.8)$ & \multicolumn{2}{|c|}{$\begin{array}{cc}10(14.9) & 16(23.9) \\
26(38.8) & \\
\end{array}$} & $67(100)$ \\
\hline 準農 村群 & $\begin{array}{c}4(2.8) \\
15\end{array}$ & $11(7.6)$ & $60(41.7)$ & $\begin{array}{r}32(22.2) \\
69\end{array}$ & $\begin{array}{l}37(25.7) \\
7.9)\end{array}$ & $114(100)$ \\
\hline
\end{tabular}

(\%)

表 4 初診時50gOGTT飞おけるIRI反応

\begin{tabular}{|c|c|c|c|}
\hline 測定反応 正常反応 $\mid$ 低反応 & 無反応 & 計 \\
\hline
\end{tabular}

\begin{tabular}{|c|c|c|c|c|c|}
\hline 農村群 & $16(25.0)$ & $24(37.5)$ & $16(25.0)$ & $8(12.5)$ & $64(100)$ \\
\hline
\end{tabular}

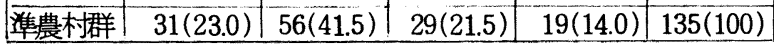

(\%)

表 6 眼 底 変 化

\begin{tabular}{|c|c|c|c|c|c|}
\hline & \multicolumn{4}{|c|}{ Wagener 分類 } & \multirow{2}{*}{ 計 } \\
\hline & 0 & I & $\mathbf{I}$ & I & \\
\hline 農 村 群 & $31(660)$ & $11(23.4)$ & $\begin{array}{r}3(6.3) \\
16(34.0)\end{array}$ & $2(4.3)$ & $47(100)$ \\
\hline 準農村群 & $83(86.4)$ & $5(5.2)$ & $\begin{array}{r}6(6.3) \\
13(13.6)\end{array}$ & $2(2.1)$ & $96(100)$ \\
\hline
\end{tabular}

表 7 血糖 の推移

\begin{tabular}{|l|c|c|c|c|c|}
\multicolumn{1}{c|}{} & $\begin{array}{c}\text { Excellect } \\
\text { Good }\end{array}$ & Good & F a i r & Poo r & 計 \\
\hline 農 村 群 & $\begin{array}{c}32(72.8) \\
32(13.6)\end{array}$ & $2(4.5)$ & $4(9.1)$ & $44(100)$ \\
\hline 準農村群 & $\begin{array}{c}60(38.7)(864) \\
104(64)\end{array}$ & $44.4)$ & $23(14.8)$ & $28(18.1)$ & $155(100)$ \\
\hline
\end{tabular}

(b)

表 8 糖尿病コントロール状態

\begin{tabular}{|c|c|c|c|c|}
\cline { 2 - 5 } \multicolumn{1}{c|}{} & G ood & F a i r & P oor & 計 \\
\hline 隻農村群 & $47(30.3)$ & $76(36.3)$ & $5(11.4)$ & $44(100)$ \\
\hline
\end{tabular}

(6)

表 10 蛋白質, 脂肪, 含水炭素平均摄取量の比較

\begin{tabular}{|c|c|c|c|c|c|}
\hline & & 蛋白質(g) & 脂肪 $(g)$ & 含水炭素 $(g)$ & 熱量 (col) \\
\hline \multirow{2}{*}{ 農 ${ }_{n=173}$ 群 } & $\mathrm{M}$ & 61.2 & 29.2 & 241.0 & 1482.4 \\
\hline & SE & 3.2 & 1.7 & 9.4 & 54.3 \\
\hline \multirow{2}{*}{$\begin{array}{c}\text { 準農村群 } \\
n=172\end{array}$} & $\mathrm{M}$ & 58.4 & 31.5 & 220.7 & 1390.9 \\
\hline & $\mathrm{SE}$ & 1.9 & 1.7 & 8.1 & 49.4 \\
\hline
\end{tabular}

表 5 高脂血症

\begin{tabular}{|c|r|rr|c|}
\cline { 2 - 4 } \multicolumn{1}{c|}{} & \multicolumn{1}{c}{ L } & \multicolumn{1}{c|}{ b } & \multicolumn{1}{c|}{ 計 } \\
\hline 農 村群 & $30(448)$ & $37(55.2)$ & $67(100)$ \\
\hline 準農村群 & $35(24.3)$ & $109(75.7)$ & $144(100)$ \\
\hline
\end{tabular}

(\%)
表 9 食慨摄取状態(指示熱量との比較)

\begin{tabular}{|c|c|c|c|c|}
\hline & 過剰摄取 & 標凖摄取 & 摄取 & 計 \\
\hline |農村 群 & $26(35.6)$ & $10(13.7$ & $37(50.7)$ & $73(100)$ \\
\hline 筂農村群 & $16(22.2)$ & $13(18.1$ & $43(59.7)$ & $72(100)$ \\
\hline
\end{tabular}

(\%) 


\section{7.僻地䅶村での糖尿病数室}

\section{高知县幡多部拳9川診潦所疋田善平}

\section{[はしめに]}

近年食事状の好転に加え。モータりぜーションの発遠にともない，都会

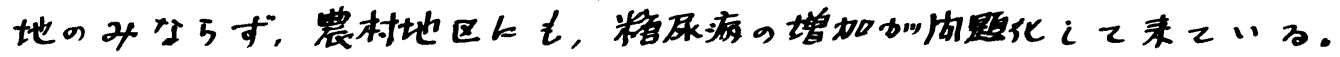

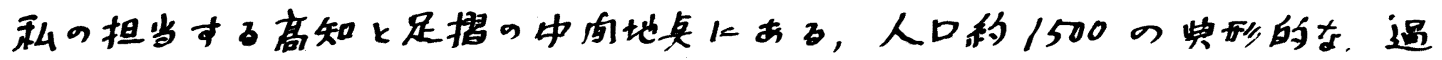

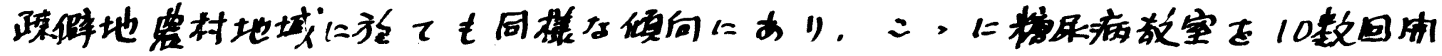

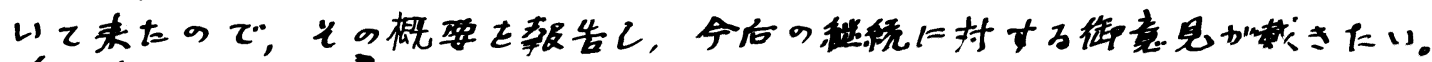
[用催目的飞理由]

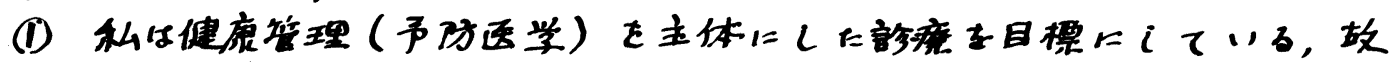

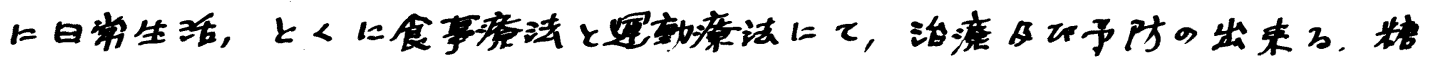

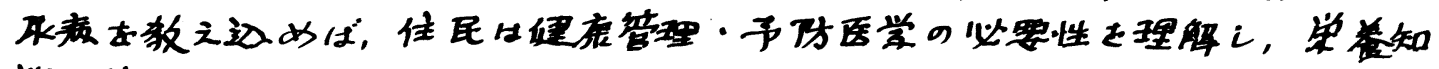
誠普及·向上加出来了。

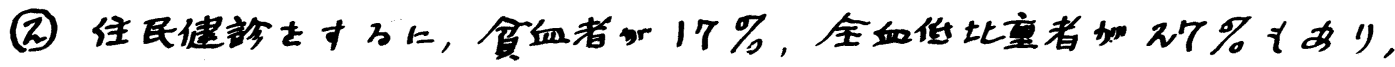

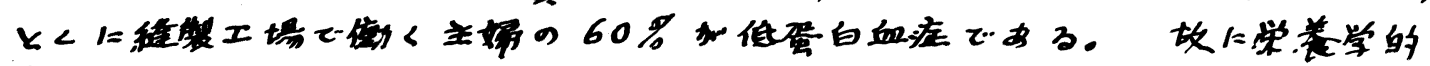

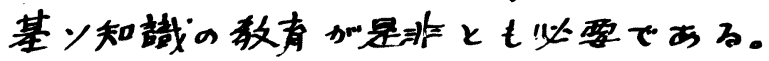

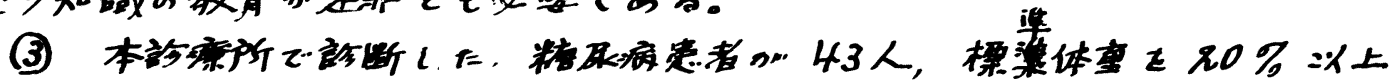

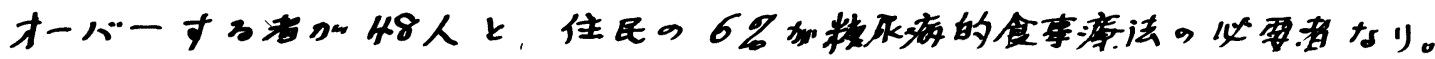

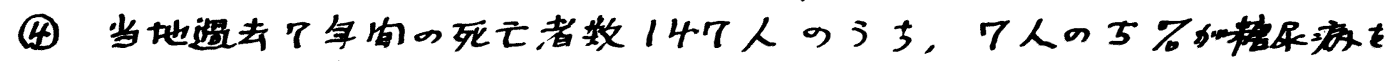

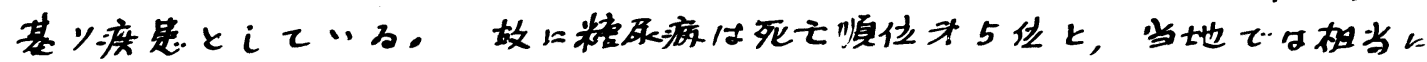

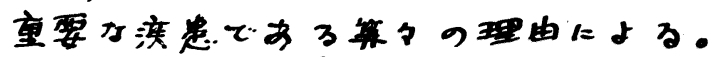

【教害闲俺潐借】

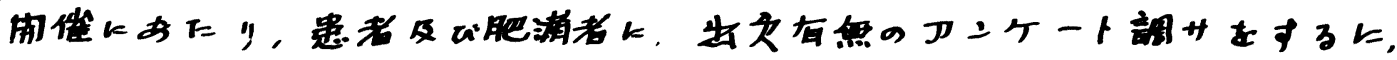

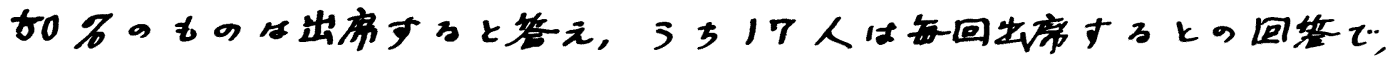

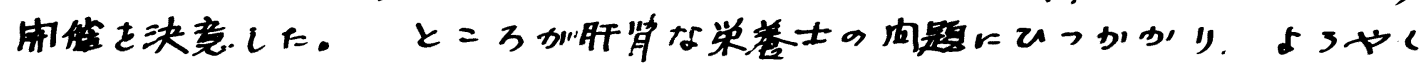

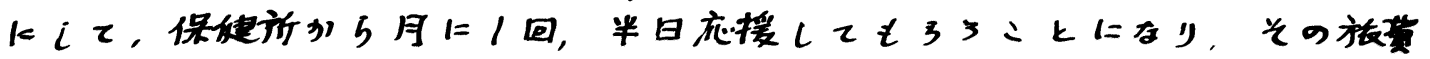

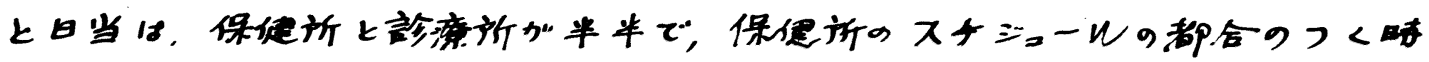
E゙サと站加決つた。

\section{〔教空用倠要倾】}

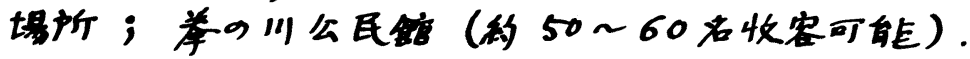

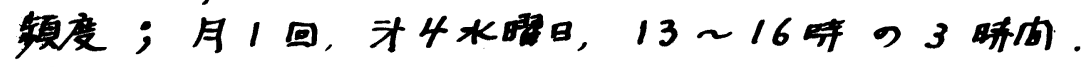

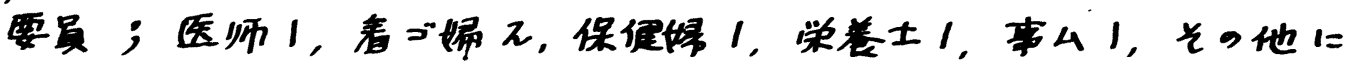

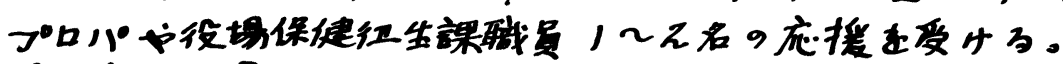
【教室内容】

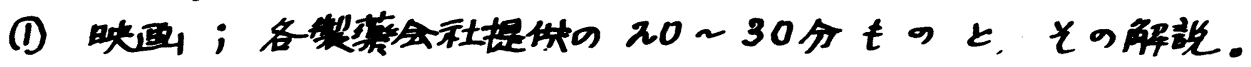




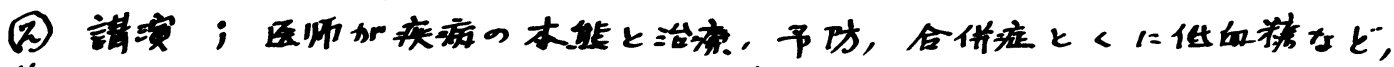

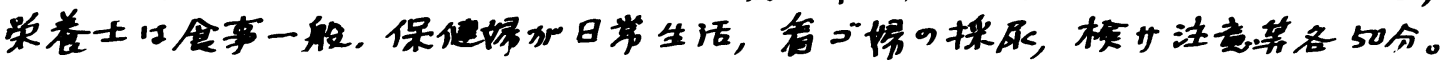

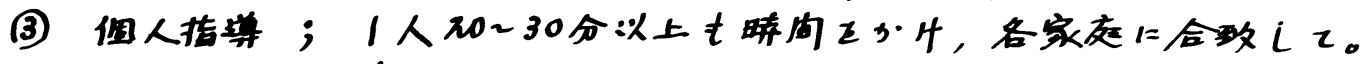

(4)食品展示；基到食と季能食品を中心ににて。

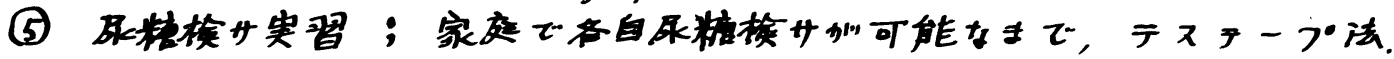

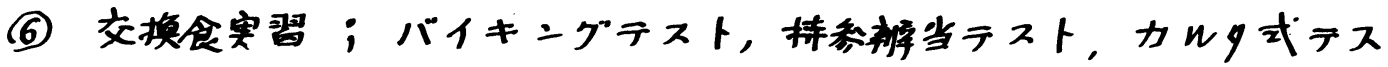
卜，外食テスト算々交换食加自由に便い二なせる上了㠰力する。

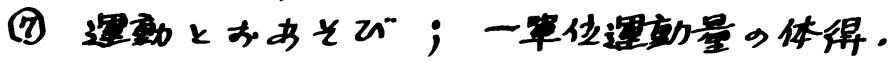

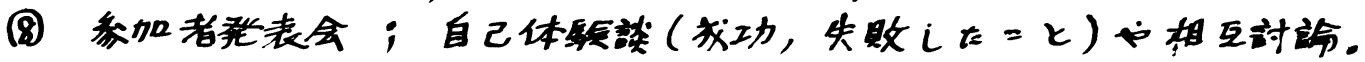

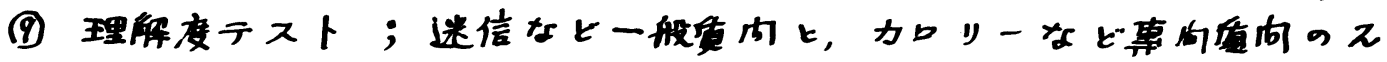

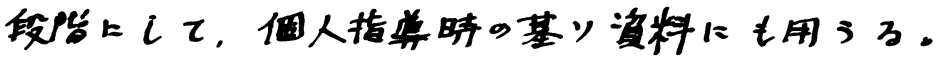

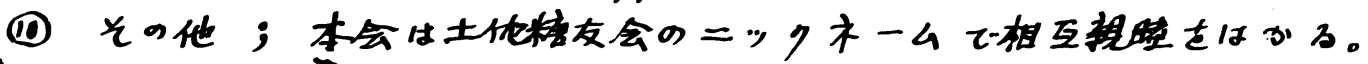
[出席数正的效果]

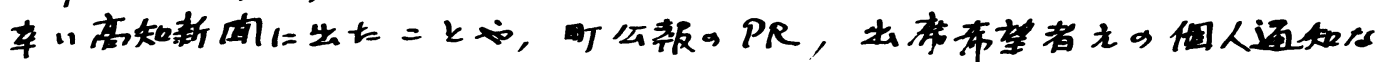

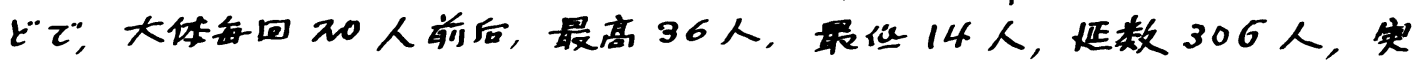

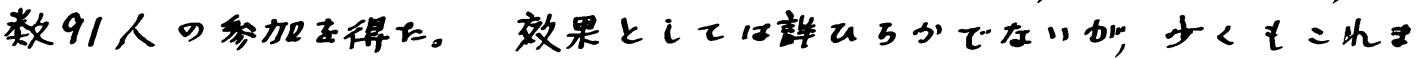

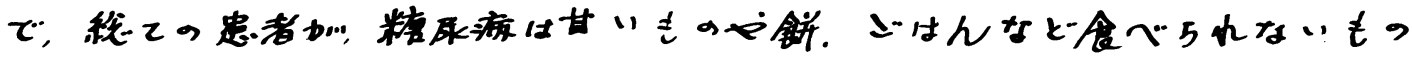

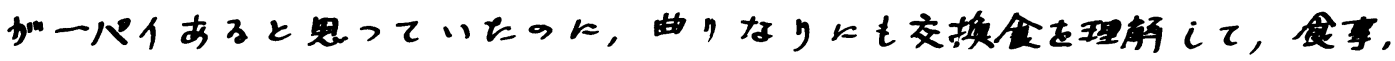

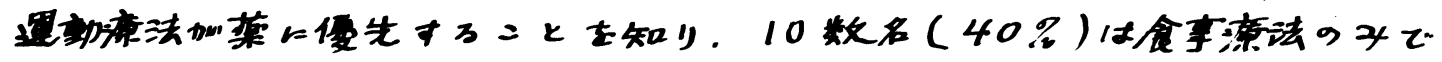
コントロール去来た然レ一般住民の予汸远学え9威心はまだへである。 【反少】

よリーアの效果を上げろため，又より出席者を多く寸ろため，町端会。

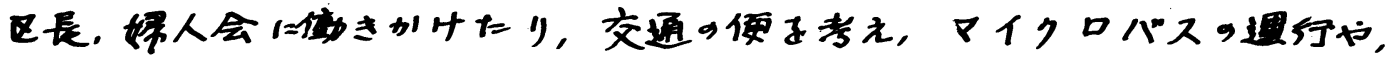

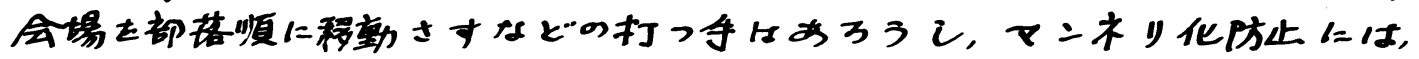

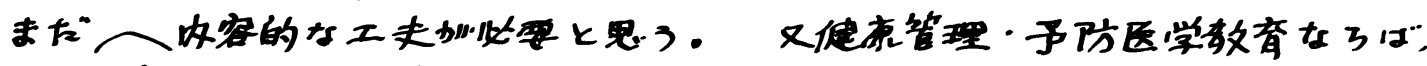

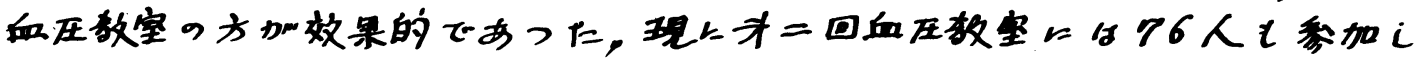

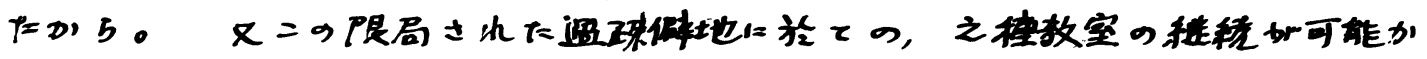

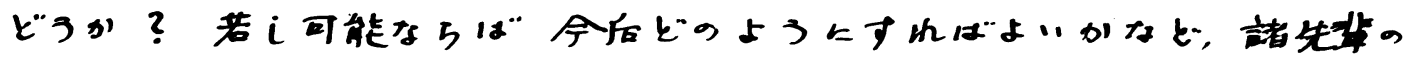

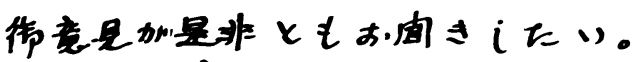

《まとめ

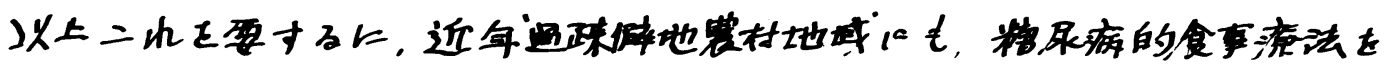

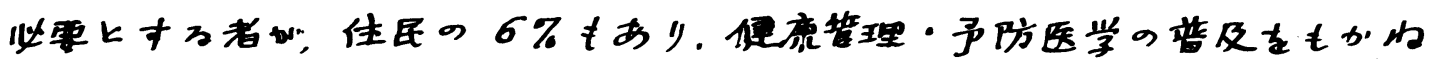

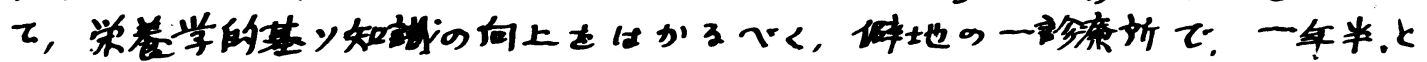

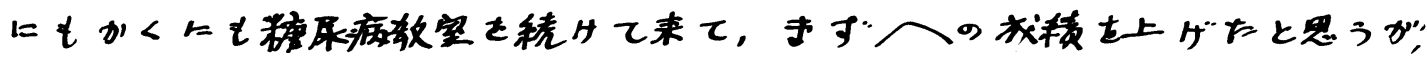

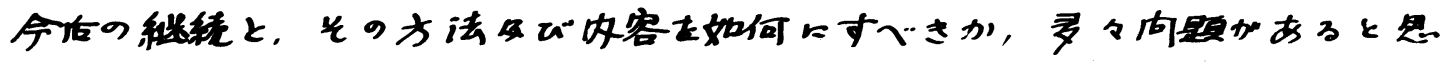
j. 
秋田界本洼・由利地域に打ける糖尿病ワリニッワ

6 年間の経驗

○估々木征子(弟士）佐々木志保子(保健㛚) 打天妙子

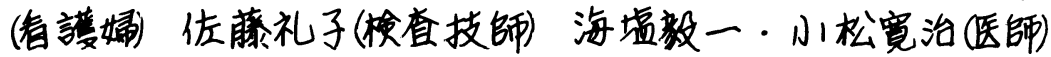
(由利組合総合病院)

当院に於いて昭和45年より糖尿病ワリニッワを開設して扬り.5 年余 リにクたり患者も1，000名以上に逢したので光の概要について都告する。

I。糖尿病ワリニック従事者は表I一1に示しにように。いすれも尃任で

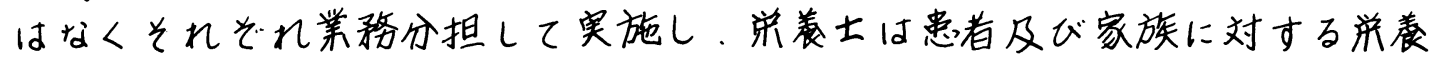
指導を行い。保健婦は生活指導。层の椧查方法、健康手帳の記戴上活用方

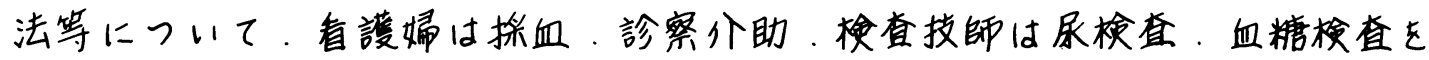
实施し、糖クリ開設は每週2日で月1回は弘前大学の専阴医を招聘してい る。これまでの登録患者数は表工ー2に示したように1.023名になって いる。男女别では表工一ろに示したように。男女比は男が女の倍であり 年令階級别では40代・50代が多く全体の半数を示している。これうの G.T.T.病型别は表Iー4に示したように。糖尿病型は80\%。境界型は1

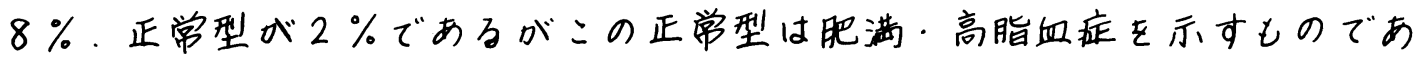

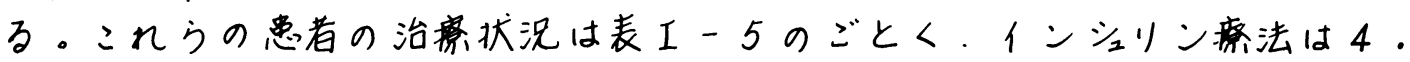
$9 \%$ 。経口投与が $25.3 \%$ ，食事痖法が70.5\%である。次に:れう の糖疗病発見理由を見ると表工一6に示するうに。健康診断時に㟋見され にものが $48 \%$ と最も多く。糖尿病固有症状は10\%にすぎない。次に 糖ワリ受診以前の治济状况では61\%が全く治康をうけていない。

开。当地域において一般集团健診時における昭49年度の尿糖陽性率は裳

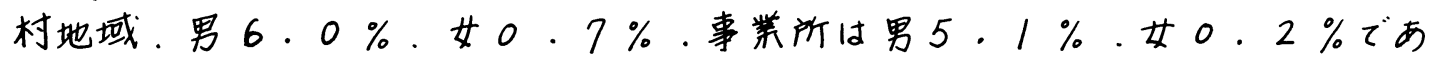
る。又, G.T.T.集団検診成精を行, 下对象について見ると。震村地域では

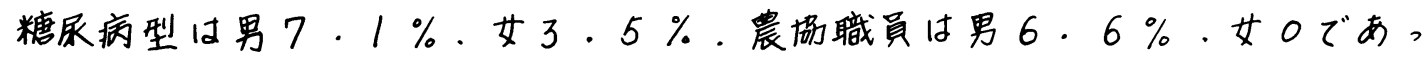
$T$.

表工一1当院に挹りる糖病病

血。当地域に扐ける糖尿病患者の 死亡原因を昭和42年〜49年名 での保健所の死亡票について見る と、脳血管疾患了 $8 \%$ を占の、心 疾患19.2\%。糖尿病 15.4 \%となっている。

ワリニッワの内容

従事者：

医饮 1 名

弟佘士 1 名……弟食指道(患者及心家族)

保健谒 1 名……生活指導・尿㭘奋方法 健康手漛の記戴及任活用方法

看護媂 2 名……診察价助・採血

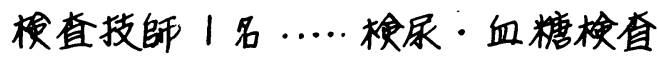

每週・金㫿日・土㫿日实施

尚、月1回弘前大学より要阴医師招搳 
表I-2

糖クリ登録患者数 (年度别)

\begin{tabular}{|c|c|}
\hline \multicolumn{2}{|c|}{ 昭和 45 年 150} \\
\hline " 46 & 208 \\
\hline$" 47$ & 191 \\
\hline "48 & 193 \\
\hline " 49 & 161 \\
\hline$" 50$ & 120 \\
\hline 計 & 1023 \\
\hline
\end{tabular}

注・昭和50年度は

8 月2日現在
表工一 4

糖ワリ患者の

病型

\begin{tabular}{|c|c|}
\hline 糖尿病型 & $\begin{array}{l}741 \\
(79.7)\end{array}$ \\
\hline 境界型 & $\begin{array}{l}167 \\
(18.0)\end{array}$ \\
\hline $\begin{array}{l}\text { 正常型 } \\
\left(\begin{array}{l}\text { 肥满 } \\
\text { 高脂血症 }\end{array}\right)\end{array}$ & $\begin{array}{r}21 \\
(2.3)\end{array}$ \\
\hline
\end{tabular}

表工一 3

年代别登録总者数

\begin{tabular}{|c|ccc|}
\hline 年代 & 男 & 女 & 計 \\
\hline $0 \sim 9$ & 2 & & 2 \\
10 & 4 & 8 & 12 \\
20 & 36 & 15 & 51 \\
30 & 132 & 39 & 171 \\
40 & 204 & 54 & 258 \\
50 & 164 & 95 & 259 \\
60 & 113 & 71 & 184 \\
70 & 29 & 26 & 55 \\
80 & 2 & & 2 \\
計 & 686 & 308 & 994 \\
\hline
\end{tabular}

年令記载なし 29

表I一 7

糖ワリ受診以前の

糖尿病発見理由

健康診断時 436(48.4) 他科受診偶然 358 (39.6) 糖尿病固存症状 $95(10.5)$

経口剂 256(25.3)

食事癌法 705 (69.8) 合併症状 $9(1.0)$ くみとリ

光の他 $3(0.3)$

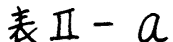

集团健診時の尿糖陽性率( B B 49年度)

（食後। 時間～万時間)

\begin{tabular}{|c|c|c|c|c|}
\hline & \multicolumn{2}{|c|}{ 震村地域 } & \multicolumn{2}{|c|}{ 各事丵所 } \\
\hline & 男 & 女 & 男 & 女 \\
\hline $\begin{array}{l}\text { 例 数 } \\
\text { 层糖陽性 }\end{array}$ & $\begin{array}{l}1780 \\
113(6.1\end{array}$ & $\begin{array}{l}2536 \\
17(0.7)\end{array}$ & $\begin{array}{l}1245 \\
63(5.1)\end{array}$ & $\begin{array}{l}501 \\
1(0.2)\end{array}$ \\
\hline
\end{tabular}
表 II - b

G.T.T.集団㭘診成績（昭46４8年） 曹村地域(由利町・象泻所上䐚) 震協娥員(5震勀団体)

\begin{tabular}{|c|c|c|c|c|}
\hline & \multicolumn{2}{|c|}{ 農村地域 } & \multicolumn{2}{|c|}{ 震勀娥員 } \\
\hline & 男 & 女 & & 女 \\
\hline 列 数 & 224 & 287 & 105 & 47 \\
\hline 型 & $122(54.5)$ & $196(68.3)$ & $49(46 . ?$ & $23(48.9)$ \\
\hline 竟界型 & 86 (38.4) & $81(28.2)$ & $49(46.7)$ & $24(51.1)$ \\
\hline 糖层病型 & $16(7.1)$ & $10(3.5)$ & $7(6.6)$ & 0 \\
\hline
\end{tabular}

治症状況

\begin{tabular}{|c|c|c|}
\hline \multicolumn{2}{|c|}{ インシュリン 経ロ绪 } & $69(6.7)$ \\
\hline \multicolumn{2}{|c|}{ インシュリン } & $12(1.2)$ \\
\hline 释 & 刘 & $163(15.9)$ \\
\hline 食 & 法 & $50(4.9)$ \\
\hline 治 痹 & ぬ & $627(61.3)$ \\
\hline
\end{tabular}

注・低血糖の程験者 16(1.6) ケトージス $2(0.2)$

表正

糖尿病者の死亡原因

(本萡・由利地域) 昭42 49年

一保健所死亡票上小一

1 脳血管疾患……4 0 名(38.5) 2 心疾患……20 (19.2) 3 糖 层病…1. 16 (15.4) 4 肺炎及ざ気管支炎‥8 5 悪性新生物 ……6 6 (5.8) 6 肝炎・䀒硬变…4.4 (3.8) 7腎不全・尿毒症…3 (2.9) 8 感染症……2 9 之の他 $\cdots \ldots . .5$ (4.7) 


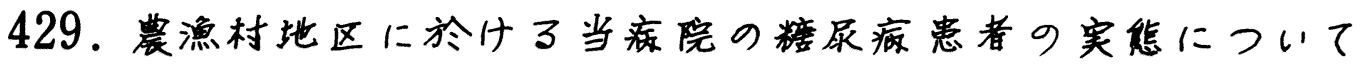

○中山祀王浩秋童一人

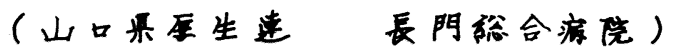

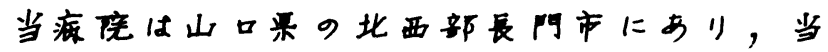
地方の基㒛病院として存在を琶的られている。

当市の比侧は日本海に面し，湾業を中心上

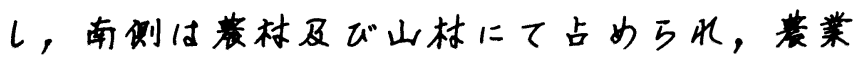
を主体としている。

（目的）昭和49年度に当病院内科に受診し， 外来で管理中の糖尿症点者114名につき，程

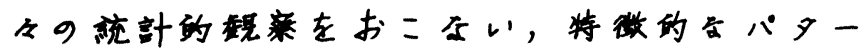
ンで为発是出来得北ばと考兀調查に着手した。 （結果）内科外来患者数心657名9中で，信

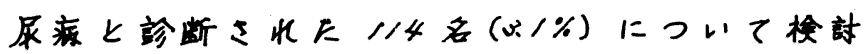
した。内放は男性63名，女性け

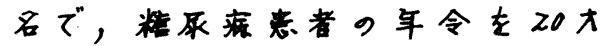
婜位で考えた場合，50 60オ代

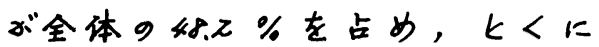
男性では40〜媇代にピーフを 示し，女性では心0〜蚛たに゚ー つを示した。

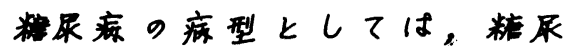
病型み゙全体986\%占め，关9 中でも50 60大代がけZ\%を占め ていた。境录型はは侧(1Z.Z\%)で あつた。

地域分布について分颣してみた。贵村地区 に居住している者が全体のけて％を占め，中阴

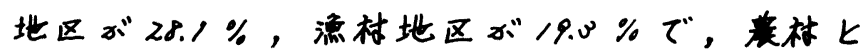
漂村地区にの数の格差が特微的であった。

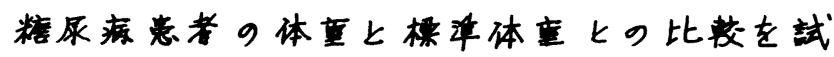
みてみにが，10 Kg以上增加例が $13.2 \%$ であつ

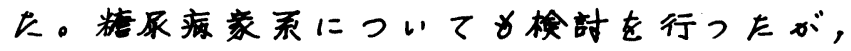
有䏝疗病家系が心.ノ％，非家乘が28.9\%で，

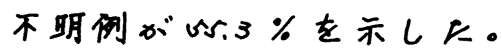

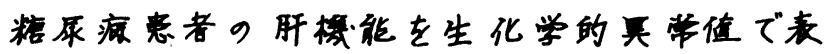

\begin{tabular}{|c|c|c|c|c|}
\hline 年令 & 男 & 女 & 3十 & $(0 \%)$ \\
\hline $20 \cdot 24$ & 1 & 0 & 1 & 0.9 \\
\hline $25 \sim 29$ & 0 & 1 & / & 0.9 \\
\hline $30 \sim 34$ & 0 & 0 & 0 & - \\
\hline $35-39$ & 8 & 3 & 11 & 9.6 \\
\hline $40-44$ & 10 & 0 & 10 & 8.8 \\
\hline $45 \sim 49$ & 10 & 5 & 15 & 13.2 \\
\hline $50-54$ & 8 & 9 & 17 & 14.9 \\
\hline $55-59$ & 3 & 10 & 13 & 11.4 \\
\hline $60 \sim 64$ & 8 & 7 & 15 & 13.2 \\
\hline $65-69$ & 3 & 7 & 10 & 8.8 \\
\hline $70-74$ & 7 & 7 & 14 & 12.3 \\
\hline $75-79$ & 3 & 2 & 5 & 4.4 \\
\hline $80 \sim 84$ & 2 & 0 & 2 & 1.8 \\
\hline Total & $63(55.39)$ & I(8\%7\%) & 114 & \\
\hline
\end{tabular}

走乙糖尿病患者の病型と年令

\begin{tabular}{|c|c|c|c|c|c|}
\hline 年令 & 若年型 & 境界型 & 啸层病型 & 吱 & $(0 \%)$ \\
\hline $20 \sim 29$ & 0 & 0 & 2 & 2 & 1.8 \\
\hline $30 \sim 39$ & I & 4 & 6 & 11 & 9.6 \\
\hline $40 \sim 49$ & I & 4 & 20 & 25 & 21.9 \\
\hline 50.59 & 0 & 1 & 29 & 30 & 26.3 \\
\hline $60 \sim 69$ & 0 & 3 & 22 & 25 & 21.9 \\
\hline $70 \sim 79$ & 0 & 1 & 18 & 19 & 16.7 \\
\hline $80 \sim 89$ & 0 & 1 & 1 & 2 & 1.8 \\
\hline Total & $2(1.8 \%)$ & $14(12.2 \%)$ & $98(86.0 \%)$ & 114 & \\
\hline
\end{tabular}

表了

糖尿满患者の地城分布

\begin{tabular}{|c|c|c|cc|}
\hline 地城 & 男 & 女 & 就 & $(\%)$ \\
\hline 最村 & 33 & 27 & 60 & 52.6 \\
漁村 & 8 & 14 & 22 & 19.3 \\
中間 & 22 & 10 & 32 & 28.1 \\
\hline$T_{0}$ tal & 63 & 51 & 114 \\
\hline
\end{tabular}

来4

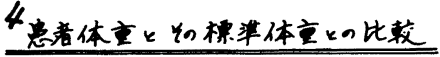

\begin{tabular}{|c|c|c|c|c|}
\hline 体重差(kg) & 男 & 女 & हो & $(0 / 0)$ \\
\hline (t) $31 \sim 40$ & 1 & 0 & 1 & 1.3 \\
\hline $21 \sim 30$ & 0 & 0 & 0 & - \\
\hline $11 \sim 20$ & 2 & 7 & 9 & 11.8 \\
\hline $6 \sim 10$ & 14 & 9 & 23 & 30.3 \\
\hline $0 \sim 5$ & 18 & 11 & 29 & 38.2 \\
\hline $0 \sim \xi$ & 3 & 7 & 10 & 13.2 \\
\hline$(-1) 6 \sim 10$ & 3 & 1 & 4 & 5.3 \\
\hline Total & 41 & 35 & 76 & \\
\hline
\end{tabular}


ホした。76痤例中兵 常值を全く示士心 $つ$ 症例が心例( $19.7 \%)$ で，约80\%はいずれ かの项目で界学侐を 示していた。

楼存病老者 $923 \%$

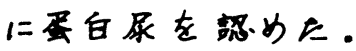

粒承症党者につい て合併症を表示した。 48\%に高血压吉伴い， 单の中に6 名 $(0.0 \%)$

东保

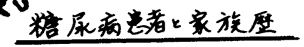

\begin{tabular}{|c|c|c|}
\hline 家族原 & 矵较 & $\%$ \\
\hline 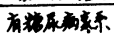 & 12 & 15.8 \\
\hline 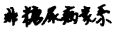 & 22 & 28.9 \\
\hline 不 & 42 & 55.3 \\
\hline Total & 76 & - \\
\hline
\end{tabular}

表6糖尿病意着口肝科能

\begin{tabular}{|c|c|c|c|c|}
\hline 是常欮見 & 男 & 女 & 竍 & $\%$ \\
\hline 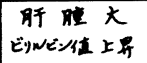 & $\begin{array}{l}9 \\
3\end{array}$ & $\begin{array}{l}7 \\
5\end{array}$ & $\begin{array}{r}16 \\
8\end{array}$ & $\begin{array}{l}21.0 \\
10.5\end{array}$ \\
\hline$A / G$ 比低下 & 7 & 21 & 28 & 36.8 \\
\hline 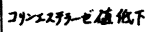 & 13 & 8 & 21 & 27.6 \\
\hline GOT 上开 & 10 & 8 & 18 & 23.7 \\
\hline GPT上异 & 12 & 10 & 22 & 28.9 \\
\hline 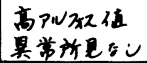 & 9 & 15 & $\begin{array}{l}24 \\
15\end{array}$ & $\begin{array}{l}31.6 \\
19.7\end{array}$ \\
\hline \multicolumn{3}{|l|}{ Total } & \multicolumn{2}{|c|}{76 在例 } \\
\hline
\end{tabular}

表 7

\begin{tabular}{|c|c|c|c|c|}
\hline 是节新兄 & 是 & 女 & 31 & $\%$ \\
\hline 蛋因尿 & 7 & 9 & 16 & 22.9 \\
\hline クレアーN上开 & 12 & 16 & 28 & $k 0.0$ \\
\hline クレP4ニン 上开 & 3 & I & 4 & 5.7 \\
\hline 展期值上并 & 5 & 2 & 7 & 10.0 \\
\hline 是岁的 & \multicolumn{4}{|c|}{37} \\
\hline Total & \multicolumn{4}{|c|}{70 症例 } \\
\hline
\end{tabular}

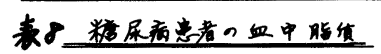

\begin{tabular}{|c|c|c|c|c|}
\hline 兵常新几 & 男 & 4 & 27 & $\%$ \\
\hline IVステロ-N1L天f & 16 & 20 & 36 & $\$ 3.7$ \\
\hline 中性新加上开 & 14 & 9 & 23 & 34.3 \\
\hline 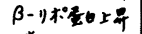 & 11 & 9 & 20 & 29.9 \\
\hline 燐服盾上开 & 5 & 3 & 8 & 11.9 \\
\hline 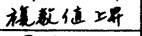 & & & 22 & 32.8 \\
\hline 是常なし & \multirow{2}{*}{\multicolumn{4}{|c|}{$\frac{31}{67 \text { 在例 }}$}} \\
\hline Total & & & & \\
\hline
\end{tabular}

9华中登作を会んで

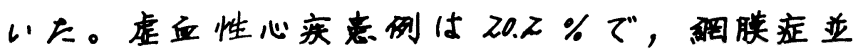
に暂症例は低值であつた。

消化性洪痛 9合併症は79\%9高率を占め，

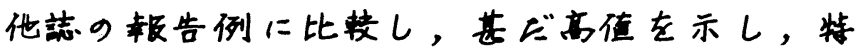

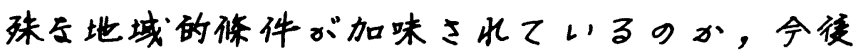
の望题として柃封して行きたい。

誌上の各表については，発表時に口速で説 明を加えたい。

\begin{tabular}{|c|c|c|c|c|}
\hline 合样症 & 男 & + & $5 t$ & $\%$ \\
\hline \multirow{6}{*}{ 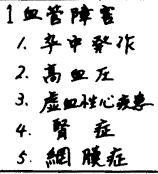 } & & & & \\
\hline & 5 & I & 6 & 5.3 \\
\hline & 30 & 25 & 55 & 48.2 \\
\hline & 12 & 11 & 23 & 20.2 \\
\hline & 1 & 4 & 5 & 4.4 \\
\hline & 2 & 3 & 5 & 4.4 \\
\hline \multirow{4}{*}{ 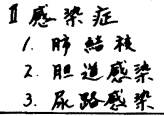 } & & & & \\
\hline & 6 & 2 & 8 & 7.0 \\
\hline & I & 2 & 3 & 2.6 \\
\hline & 7 & 12 & 19 & 16.7 \\
\hline \multirow{4}{*}{ 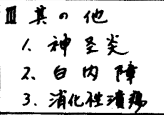 } & & & & \\
\hline & I & I & 2 & 1.8 \\
\hline & 2 & 6 & 8 & 7.0 \\
\hline & 6 & 3 & 9 & 7.9 \\
\hline Total & & 114 & 在 13 & \\
\hline
\end{tabular}

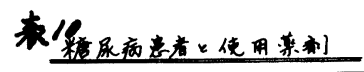

\begin{tabular}{|c|c|c|c|}
\hline 来制 s & 是 & $女$ & 27 \\
\hline$x_{1} y_{1}=2 \% .9 x_{x}-10$ glibenclamide & 24 & 30 & 54 \\
\hline F24IX. XIIXD Tolbutamide & 7 & 3 & 10 \\
\hline Buformin & 3 & 3 & 6 \\
\hline Acetotexamide & 4 & 2 & 6 \\
\hline 4"pxy)S glogeppynamide & 2 & 2 & 4 \\
\hline IカIーN glycodiagion & 1 & 3 & 4 \\
\hline Iandin & 2 & 7 & 9 \\
\hline
\end{tabular}

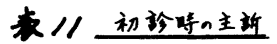

\begin{tabular}{|c|c|c|c|}
\hline 主新 & $\%$ & 主新 & $\%$ \\
\hline 口 36 & 22.5 & 难 & 2.3 \\
\hline 佬总空 & 18.6 & 食具不渡 & 1.6 \\
\hline ろいもう & 9.3 & 盗 汗 & 1.6 \\
\hline 顽感 & 8.5 & め $\neq \omega$ & 1.6 \\
\hline ）层 & 6.8 & 吟吸里数 & 1.6 \\
\hline 海喑 & 5.4 & 视力呠至 & 0.8 \\
\hline 心情元迄 & 4.7 & 粯尿 & 0.8 \\
\hline 狎全洲 & $4 \cdot 7$ & 帐 㳻 & 0.8 \\
\hline leides & 2.3 & 便 杖 & 0.8 \\
\hline 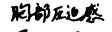 & 2.3 & 步行泍事 & 0.8 \\
\hline 胥 6 伥 & 2.3 & & \\
\hline
\end{tabular}


430. 当院糖尿病専門外来における疾病管理の現況

\section{○土屋 和子(千楪大・医・農医研)}

甲府共立病院・糖尿病専門外未王ルー70

〔はじめに〕糖尿病患者の治療およで生活管理にあたって，糖疗病専門 外来の果す役割は非常に大きい。S42 年糖尿病患者会「共親会」が発足し 患者增と相まって当院においても尃門外来が南設された。医師2，看姜婦

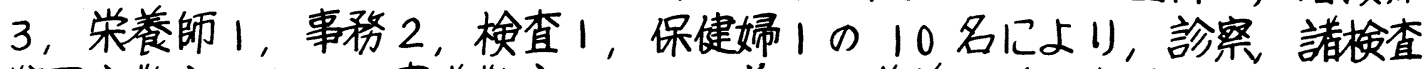
糖疗病教室における患者教育（個人，集団）栄养指導，患者手帳及び管理 カードの記入，中断患者对策等を分担している。現在 Fallow up 中の患者 295 名について，性，年令，職業，遣䛃貢荷，発見の動機，体型，血圧， 血清脂稹，血糖值，心電困，眼底，治療方法，中断，死亡の原因，病気の 知識及乙゙食䭒に成才る理解度のテストを実施して外来糖尿病管理の古題点 を検討したので報告する。(結果〕1)年令構成：男151名，女144名で男 女とも $20 ， 30$ 代が少なく40〜60 代が $76 \%$ であった(表|)。2)職業， 遺伝負荷：男は勤務者，女は無職が多かった。遗伝負荷のある者は51名 （17.3\%）で男女差はなかった（表2）。3）発見の動機：何等かの主訴によリ 受診したものが $74.9 \%$ で，次は集検で発見されている。主訴は口喝，多领 多尿，体重減少，視力低下，四肢の異常感賞の順位であった。(表3)。4)治 療方法：男女とも内服菜治療が $50 \%$ を越之ていた(表4)。5)体型：男女 ともに肥㴖が多かった。(四I)。6)体型と血圧，血清脂盾，血糖値：肥满群 に高血圧が多く，やせ型に正常血王が多かった。血清脂稹の異常は，高Ch 血症，高T伯血症とも肥满群にみられた。FBS はや世型嚆かった。(表5) 6)羅病期间七血圧，心電四，眼底：3年未㴖群では正常血圧が多人，罹病 期间が長くなると高血圧が多くなった。儿電四は，3年未満群江正常者が 多かった。眼底の变化は，罹病期间が長くなる程その頻度を增し，10年 以上経過群では $63.6 \%$ に網膜症がみられた（表 6)。7)テストの平均点数： 外来通院 81 名（男 41，女40）を対象に23问のテストを实施した。问題 は食事につき７问，治療法につき3古，低血糖に肉して3问，常識问題10 问である。成績壮表ワの如くで，常識及で低血糖に夙してはかなり理解さ れているが，治療内容，食慨に岡しては成縝が悪かった。治療方法別にみ るとインスリン群が成績がよかった。8)中断患者：中断 40 名 (13.6\%) で，男 40 代食慨療法群に，女60代内服治療群に多かった。中断理由村 全治したと思った。㜊がない。通院が不便，待時间が長い等で，糖尿病を 軽視していることがうかがえた（表 8) 9)死因：死亡13 例（4.4\%) で死 因表9 の如くで三村の 48 例に近く，Joslin clinic とは，心死と脳血管死 が逆となり民族性を現わしていた。(まとめ〕以上の調査より，患者教育の 
困難さを再認識するとともに、外来管理に当っては治噔の中断を強く戒め ると共に，正しい病態の理解のもとに適切な治療を患者の生涯に㓅たつて続け さ世，好発する合併症を防止して健康者と变ら社会活動に従事して，有竟義 な人生を送るように良好な管理状態を長期に継続させることが大切である。

表1。年令構成

\begin{tabular}{|c|r|r|r|r|r|r|c|}
\hline & 29х & $30 \sim$ & $40 \sim$ & $50 \sim$ & $60 \sim$ & $70 \sim$ & 計 \\
\hline 男 & 6 & 14 & 37 & 32 & 43 & 19 & 151 \\
& $(4.0)$ & $(9.2)$ & $(24.5)$ & $(21.2)$ & $(28.5)$ & $(12.6)$ & $(100)$ \\
\hline$女$ & 2 & 4 & 23 & 50 & 39 & 26 & 144 \\
女 & $(1.4)$ & $(2.8)$ & $(16.0)$ & $(34.7)$ & $(27.0)$ & $(18.1)$ & $(100)$ \\
\hline 計 & 8 & 18 & 60 & 82 & 82 & 45 & 295 \\
$(2.7)$ & $(6.1)$ & $(20.3)$ & $(27.8)$ & $(27.8)$ & $(15.3)$ & $(100)$ \\
\hline
\end{tabular}

表3。発見の動機

\begin{tabular}{|c|c|c|c|c|c|c|}
\hline & 当診 & 集娭 & 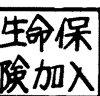 & $\begin{array}{l}\text { 〈みk } \\
\text { 1)屋 }\end{array}$ & 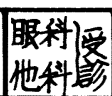 & \\
\hline 男 & {$[(74.8)$} & $\begin{array}{c}29 \\
(19.2)\end{array}$ & $\begin{array}{c}5 \\
(3.3)\end{array}$ & $\begin{array}{c}1 \\
(0.7)\end{array}$ & $\begin{array}{c}3 \\
(1.9)\end{array}$ & \\
\hline 女 & $\begin{array}{l}108 \\
(75.0)\end{array}$ & & $(0.7)$ & $\begin{array}{c}2 \\
(1.4)\end{array}$ & \begin{tabular}{|c}
4 \\
$(2.8)$ \\
\end{tabular} & \\
\hline 計 & & & & $\begin{array}{c}3 \\
(1.0)\end{array}$ & 7 & \\
\hline
\end{tabular}

表 2. 職業，遺伝勇荷

\begin{tabular}{|c|c|c|c|c|c|c|c|}
\hline & 蕽業 & 勤務 & 自営業 & 無職 & [9)他 & 計 & 遗伝 \\
\hline 男 & $\begin{array}{c}14 \\
(9.3)\end{array}$ & \begin{tabular}{|c|}
55 \\
$(36.4)$
\end{tabular} & $\begin{array}{c}24 \\
(15.9)\end{array}$ & $\begin{array}{c}29 \\
(19.2)\end{array}$ & 29 & $\begin{array}{l}151 \\
(100)\end{array}$ & $\begin{array}{l}25 \\
6.6)\end{array}$ \\
\hline 女 & $\begin{array}{c}15 \\
(10.4)\end{array}$ & $\begin{array}{l}11 \\
(7.6)\end{array}$ & $\begin{array}{c}5 \\
(3.5)\end{array}$ & $\begin{array}{l}11 \\
(77.8)\end{array}$ & $(0.7)$ & $\begin{array}{l}144 \\
(100)\end{array}$ & $\begin{array}{c}26 \\
(18.1)\end{array}$ \\
\hline & 29 & $\begin{array}{l}66 \\
22.4\end{array}$ & $\begin{array}{l}29 \\
(9.8)\end{array}$ & & 30 & 295 & \\
\hline
\end{tabular}

表4. 治療方法

\begin{tabular}{|c|c|c|c|c|c|}
\hline & 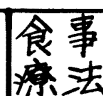 & (1) & 内服茅 & $\mid \begin{array}{l}\text { 胫 } \\
\text { 内啿 }\end{array}$ & 計 \\
\hline 男 & $\begin{array}{c}46 \\
(30.5)\end{array}$ & $\begin{array}{c}24 \\
(15.4)\end{array}$ & $\begin{array}{l}77 \\
(51.0)\end{array}$ & $(2.6)$ & $\begin{array}{l}151 \\
(100)\end{array}$ \\
\hline 女 & $\begin{array}{c}27 \\
(18.8)\end{array}$ & $\begin{array}{c}23 \\
(16.0)\end{array}$ & $\begin{array}{c}86 \\
(59.7) \\
\end{array}$ & $\begin{array}{c}8 \\
(5.5)\end{array}$ & $\begin{array}{l}144 \\
(100)\end{array}$ \\
\hline 計 & $\begin{array}{c}73 \\
(24.7) \\
\end{array}$ & $\begin{array}{c}47 \\
(15.9) \\
\end{array}$ & $\begin{array}{c}163 \\
(55.3) \\
\end{array}$ & $\begin{array}{r}12 \\
(4.1 \\
\end{array}$ & 295 \\
\hline
\end{tabular}

表 5. 体型と血王，血清脂质，血糖值

\begin{tabular}{|c|c|c|c|c|c|c|c|c|}
\hline & 血生 & & $\begin{array}{l}\text { IL } \\
\text { テロ }\end{array}$ & & $\begin{array}{l}\text { kリ? } \\
\text { 七ラ }\end{array}$ & & $=B$ & \\
\hline & At & & )] & 24 & & 15 & -1401 & $|4| \sim$ \\
\hline 巴㺃 & \begin{tabular}{l|l}
77 & 27 \\
\end{tabular} & 47 & 95 & 43 & 73 & 65 & 67 & 85 \\
\hline & \begin{tabular}{l|l}
38 & 18 \\
\end{tabular} & 50 & 78 & \begin{tabular}{|l|}
17 \\
\end{tabular} & 71 & 24 & 42 & 61 \\
\hline & \begin{tabular}{|l|l|}
10 & 2 \\
\end{tabular} & 20 & 26 & 4 & 27 & 3 & & 24 \\
\hline
\end{tabular}

表 6. 罹病期间と血圧，心電田，眼底所見

\begin{tabular}{|c|c|c|c|c|c|c|c|c|c|c|}
\hline & $\begin{array}{l}\text { 高 } \\
\text { 䙶 }\end{array}$ & $\begin{array}{l}\text { 境 } \\
\text { 界 }\end{array}$ & $\begin{array}{l}\text { 正 } \\
\text { 常 }\end{array}$ & & & “正 & 計 & & & \\
\hline & 32 & 19 & 44 & 95 & 27 & 68 & 95 & 24 & 14 & \\
\hline 59 & 28 & 16 & 19 & 63 & 39 & 33 & 72 & 17 & 15 & 3 \\
\hline & 38 & 8 & 20 & 66 & 40 & 29 & 69 & 16 & 22 & 38 \\
\hline & 14 & & 12 & 35 & 19 & 20 & & 8 & 14 & 22 \\
\hline & & & & & & & & & & \\
\hline
\end{tabular}

表7. テス卜平均点数(20点满点)

\begin{tabular}{|c|c|c|c|c|}
\hline & 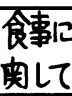 & & & $\begin{array}{l}\text { 常識 } \\
\text { 问题 }\end{array}$ \\
\hline 全 体 & 9.2 点 & 6.0 & 13,3 & 18. \\
\hline 男 & 8.6 & 5.0 & 14.9 & 118. \\
\hline 女 & 9.7 & 6.9 & 11.8 & 18.1 \\
\hline 食事療法 & 8.7 & & 10.3 & 18. \\
\hline 5 丙服致 & 9.0 & 36 & 13.6 & 18.0 \\
\hline 去倡ス & 0.1 & 12.4 & 16.2 & \\
\hline
\end{tabular}

因 1. 体型

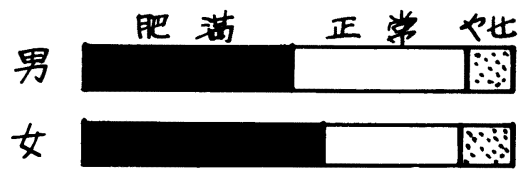

表8.中断患者 (性、年令，治療方法)

\begin{tabular}{|c|c|c|c|c|c|c|c|c|c|c|}
\hline & -29 & & & & & Or & 計 & 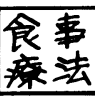 & $\begin{array}{l}\text { インス } \\
\text { 1) }\end{array}$ & 内服 \\
\hline 男 & 2 & 4 & 10 & 7 & $\overline{3}$ & 2 & 28 & 15 & 3 & 10 \\
\hline 女 & 1 & & 1 & 2 & 6 & 2 & 12 & 2 & 2 & 8 \\
\hline 計 & 3 & 4 & 11 & 9 & $\overline{9}$ & 4 & $\begin{array}{l}40 \\
(13.6)\end{array}$ & 17 & 5 & 18 \\
\hline
\end{tabular}

表 9. 死因

\begin{tabular}{|c|c|c|c|c|c|c|c|c|}
\hline & $\begin{array}{l}\text { 昏 } \\
\text { 睡 }\end{array}$ & $\begin{array}{l}\text { 虚心 } \\
\text { 血疾 } \\
\text { 性患 }\end{array}$ & $\begin{array}{l}\text { 脸障 } \\
\text { 血 } \\
\text { 管害 }\end{array}$ & \begin{tabular}{|c} 
腎 \\
疾 \\
患 \\
\end{tabular} & $\begin{array}{l}\text { 肝 } \\
\text { 疾 } \\
\text { 患 }\end{array}$ & 感 & & $1 x$ \\
\hline 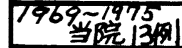 & 7.7 & 15.3 & 30.7 & 15.3 & 7.7 & 7.7 & & \\
\hline & 0.9 & 14 & 31.3 & 14.6 & 2.1 & 10.4 & 8.3 & \\
\hline & & 51 & 12.4 & 14.7 & 1.1 & 5.4 & 10.4 & \\
\hline
\end{tabular}




\title{
431. 当院における二次性糖尿病患者の観察
}

\author{
愛知愛北病院 \\ ○伊藤恭平松永俊明高田輝雄野村了 \\ 河野通明篠田広 大原清仁
}

（はじめ）近年都市、農村をとわず糖尿病の増加は著しいものがある。と ころで糖尿病は、遺伝素質の有無により一次性、二次性とに大別されてい るが、現時点では遺伝素因が明らかでなく、かつ二次性糖尿病の原因たり 得る明らかな外因のある場合、一応二次性とするのであるが(表. 1)、糖尿 病の増加傾向のなかで、現在二次性糖尿病がいかなる推移を示しているか の検討は興味深いものがある。今回わたくしどもは過去 9 年間の当院受診 二次性糖尿病患者の病態について観察したので報告する。

(観察対象) 昭和 41 年 6 月より 50 年 5 月までに当院を受診した糖尿病患者 は930例（今 533, ㅇ 397）で、うち二次性糖尿病患者は66例 ( 336, ㅇ 30), $7.1 \%$ 、そ、そ男女比は $1 ： 1.1$ と女性に高く、職業別では非農が $85 \%$ を占 めた。

(観察成績)

(1)原因別分類。表. 1 のごとく、肝 >膵 $>$ 膵以外内分泌性 $>$ 薬物を示した。

(2)年代別及び体型別。年代別では最年少者は 18 才、最高年令は 82 才で、 60 才以上 $>50$ 才代 $>40$ 才代を示し、40才以上は実に $80 \%$ を占め、若年者は 甲状腺、高年者には膵腫瘍、肝硬変が多かった。体型別では普通>肥満> やせの順で、肥満に脂肪肝、やせには膵、甲状腺疾患が多かった。

(3)重軽症別。名大第三内科の法で分類すると、軽症 $>$ 中等症 $>$ 重症の順 で、重症例は膵、肝疾患に著明であった。なおコントロール不良者は少な く、3 例(膵がん 1, へモクロマトージス 1, 甲状腺機能立進 1 ) であった。

(4)血中脂質。コレステロール、トリグリセリド、燐脂質、遊離脂酸のい づれも、正常＞増加＞減少の順であった。

(5)合併症。細小血管症については、肝硬変の 2 例に網膜症を認めた。

(6)血中インスリン (IRI) とC-ペプチド $(\mathrm{CPR})$ 。図 1,2 に示すごとく、血 中IRIは 2 抗体法により観察したが、過剩＞低＞正常反応を示した。

IR Iと C PRとの関連については、1 例の成績を図示したが、一次性、二次 性糖尿病の病態観察上示唆に富み、今后の検討課題といえよう。

(7)死亡例。表 1 ,のごとく、膵がん、肝硬変、ステロイド使用者に著しい が、基礎疾患よりして当然といえる。なお糖尿病性昏睡例は認めなかった。

8治療法。インスリン使用15例、経口剂 4 例、他は食事療法によった。

（むすび）以上の成績が示すように、糖尿病診療上、二次性糖尿病は今后 益々その重要性を増すと思われる。さらにまたその予后向上のため、早期 発見、早期治療法確立への努力が今后とも期待される次第である。 
表 1, 二次性糖尿病の分類

(Creutzfeldt)
A ) 膵ラ氏島直接障害（腫瘍、炎症、摘出、へモクロマトージス、外傷など）
B ）膵以外の内分泌性糖尿病（下垂体、副腎、甲状腺など）
C ) 薬物性糖尿病（ステロイド、サイアサイド、蛋白同化ホルモンなど）
D ) 肝性糖尿病（肝硬変、脂肪肝、糖原病など）

表 2, 原因別分類

\begin{tabular}{|c|c|c|c|c|c|c|}
\hline & \multicolumn{2}{|c|}{ 性 } & \multicolumn{2}{|c|}{ 計 } & 原 因 疾 患（）死亡例 \\
\hline \multicolumn{2}{|r|}{ 膵 } & \multicolumn{2}{|c|}{\begin{tabular}{|l|l|} 
& 6
\end{tabular}} & \multicolumn{2}{|c|}{$\begin{array}{c}17 \\
(25.8 \%)\end{array}$} & 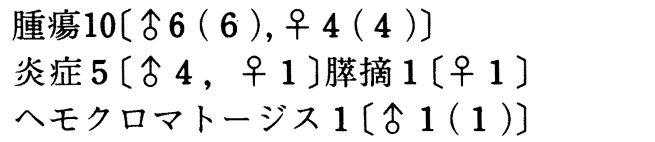 \\
\hline \multirow{3}{*}{$\begin{array}{l}\text { 膵 } \\
\text { 以 } \\
\text { 外 }\end{array}$} & 下 垂 体 & 1 & 0 & 1 & \multirow[b]{2}{*}{14} & 腫 瘍 \\
\hline & 副 & 0 & 1 & 1 & & 皮 質 腫 瘍 \\
\hline & 甲 状 腺 & 3 & 9 & 12 & $\begin{array}{r}(21.2) \\
\%\end{array}$ & 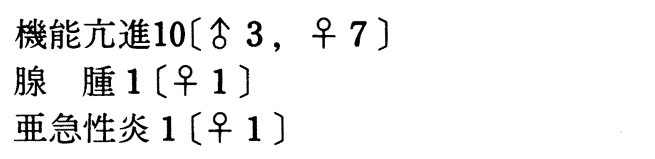 \\
\hline \multirow{2}{*}{$\begin{array}{l}\text { 薬 } \\
\text { 物 }\end{array}$} & ステロイド & 2 & 5 & 7 & \multirow{2}{*}{$\begin{array}{c}8 \\
(12.1) \\
\%\end{array}$} & 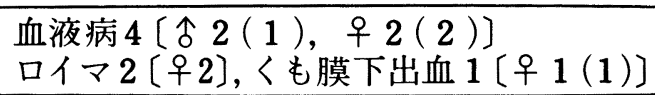 \\
\hline & サイアザイド & 0 & 1 & 1 & & 高血圧症 \\
\hline & 肝 & 19 & 8 & \multicolumn{2}{|c|}{$\begin{array}{c}27 \\
(40.9 \%)\end{array}$} & 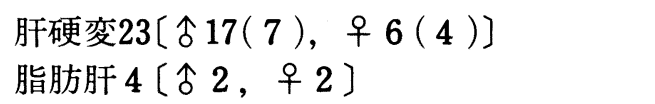 \\
\hline & & 36 & 30 & \multicolumn{2}{|c|}{66} & 死亡例26/66 $(39.4 \%)$ \\
\hline
\end{tabular}

困1.血中インスリン

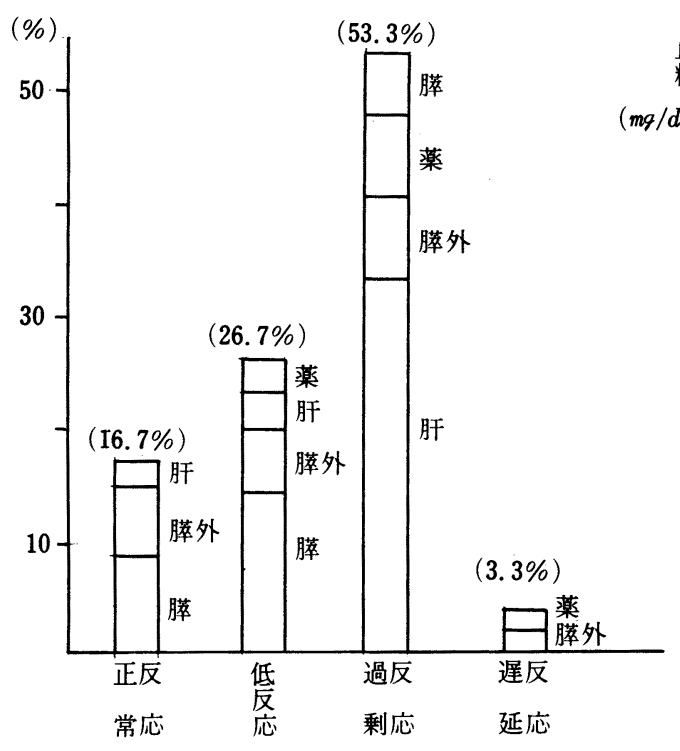

困 2．血中インスリンとC-ペプチド (IRI)

(CPR)

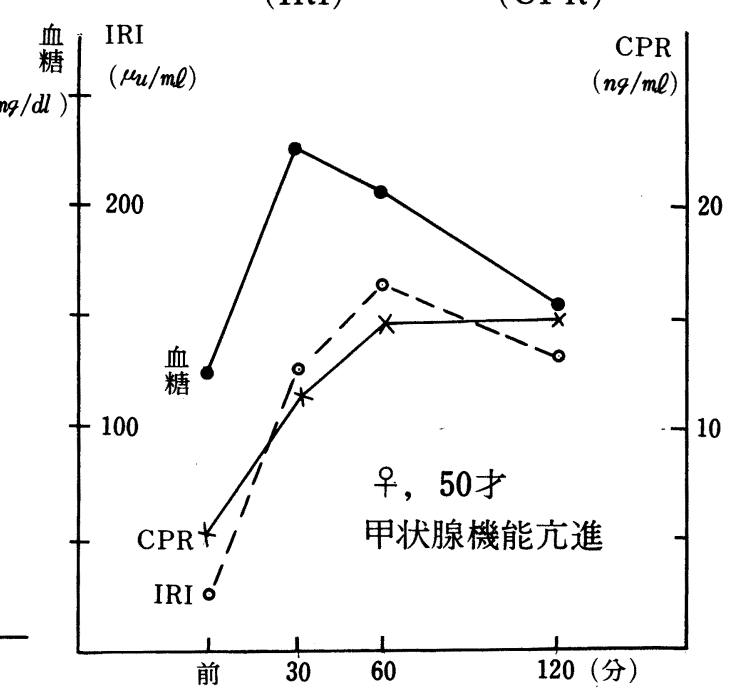

